Prepared in cooperation with the San Antonio Water System

\title{
Origin and Characteristics of Discharge at San Marcos Springs Based on Hydrologic and Geochemical Data (2008-10), Bexar, Comal, and Hays Counties, Texas
}

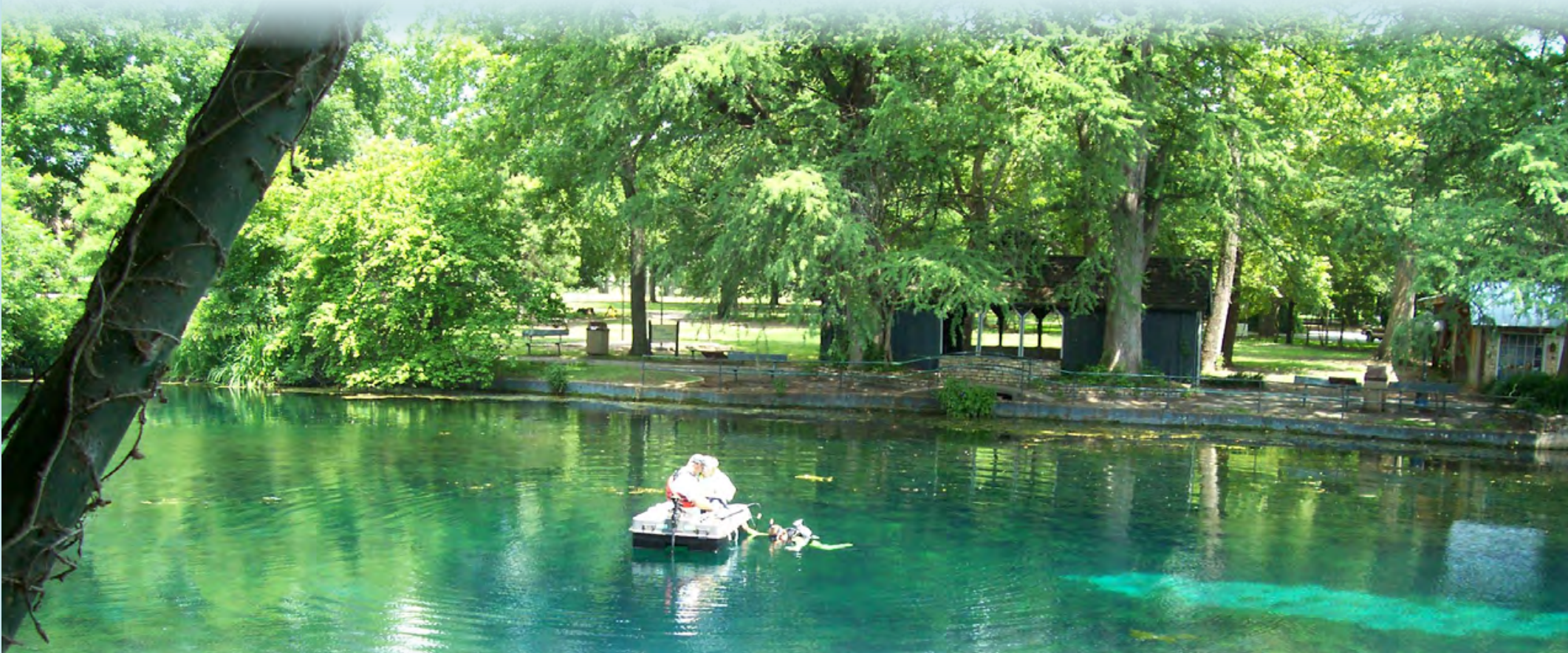

Scientific Investigations Report 2012-5126 
Front cover: U.S. Geological Survey personnel and a diver from Texas State University near Weissmuller Spring, Spring Lake, San Marcos Springs, Hays County, Texas.

Back cover:

Left, Spring Lake, San Marcos Springs, near Deep Spring, Hays County, Texas.

Right, The Blanco River, downstream from Halifax Ranch, Hays County, Texas. 


\section{Origin and Characteristics of Discharge at San Marcos Springs Based on Hydrologic and Geochemical Data (2008-10), Bexar, Comal, and Hays Counties, Texas}

By MaryLynn Musgrove and Cassi L. Crow

Prepared in cooperation with the San Antonio Water System

Scientific Investigations Report 2012-5126 


\section{U.S. Department of the Interior \\ KEN SALAZAR, Secretary \\ U.S. Geological Survey \\ Marcia K. McNutt, Director}

U.S. Geological Survey, Reston, Virginia: 2012

This and other USGS information products are available at http://store.usgs.gov/
U.S. Geological Survey
Box 25286 , Denver Federal Center
Denver, CO 80225
To learn about the USGS and its information products visit http://www.usgs.gov/
1-888-ASK-USGS

Any use of trade, product, or firm names is for descriptive purposes only and does not imply endorsement by the U.S. Government.

Although this report is in the public domain, permission must be secured from the individual copyright owners to reproduce any copyrighted materials contained within this report.

Suggested citation:

Musgrove, M., and Crow, C.L., 2012, Origin and characteristics of discharge at San Marcos Springs based on hydrologic and geochemical data (2008-10), Bexar, Comal, and Hays Counties, Texas: U.S. Geological Survey Scientific Investigations Report 2012-5126, 94 p. 


\section{Contents}

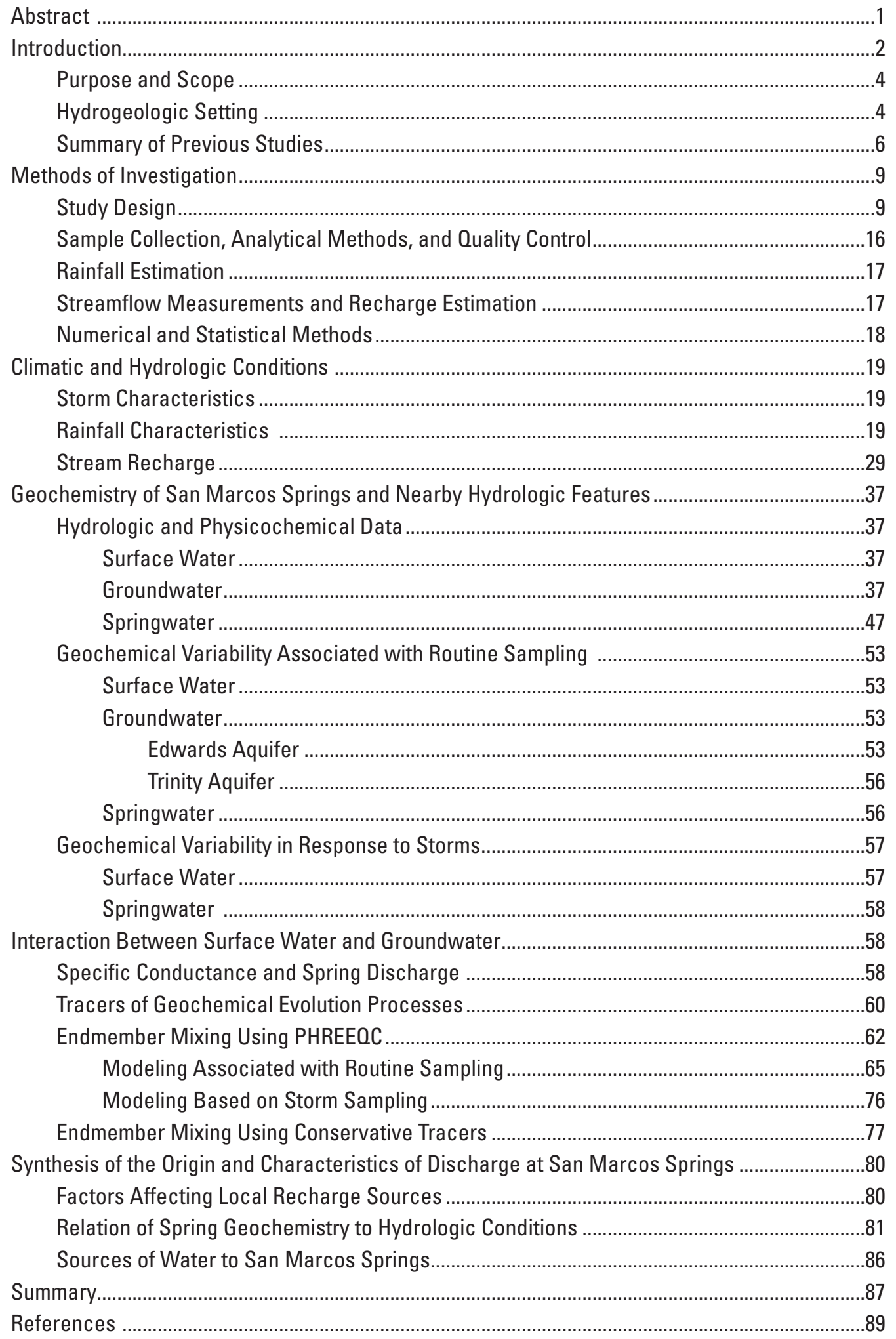




\section{Figures}

1. Study area and locations of water-quality sampling and data-

collection sites for hydrologic and geochemical characterization of

San Marcos Springs, south-central Texas.

2. Idealized block diagram of the Edwards aquifer between Comal

Springs Fault and Bear Creek Fault in the vicinity of Comal, Hueco, and

San Marcos Springs, south-central Texas.

3. San Marcos Springs, Hays County, south-central Texas...................................................

4. San Marcos Springs complex, Hays County, south-central Texas .....................................8

5. Time series (November 2008-December 2010) of $A$, stream discharge and spring discharge for multiple sites sampled for the characterization of San Marcos Springs, south-central Texas, and timing of collection of samples; and $B$, Rainfall hyetograph in the vicinity of San Marcos

Springs, Hays County, south-central Texas.

6. Rainfall hyetograph, hydrographs for streams and springs, estimated stream recharge, and timing of collection of stream and spring samples for storms in the vicinity of San Marcos Springs, south-central Texas ..

7. Estimated recharge to the Edwards aquifer from the Blanco River, Cibolo Creek, and Dry Comal Creek, south-central Texas, 2008-10.

8. Time series (November 2008-December 2010) of gain (positive values) and loss (negative values) for the Guadalupe River, south-central Texas.

9. Relation between deuterium and oxygen isotopes for rainfall samples collected at U.S. Geological Survey station 293146982941, Bexar County, south-central Texas (2008-10)

10. Estimated daily recharge to the Edwards aquifer from the Blanco River, south-central Texas, computed from two pairs of U.S. Geological Survey streamflow-gaging stations

11. Times series (November 2008-December 2010) of stream discharge, water temperature, specific conductance, turbidity, and dissolved oxygen (daily means) for U.S. Geological Survey station 08171290, and daily average rainfall in the vicinity of San Marcos Springs, south-central Texas

12. Time series (November 2008-December 2010) of selected physicochemical properties and geochemical constituents for surfacewater sites sampled for the characterization of San Marcos Springs, south-central Texas

13. Time series (November 2008-December 2010) of physicochemical properties and geochemical constituents for surface-water sites and spring sites sampled preceding and in response to storm 1 (September 2009), storm 2 (October 2009), and storm 3 (September 2010), south-central Texas.

14. Times series (November 2008-December 2010) of hydrologic and physicochemical data for two groundwater wells near San Marcos Springs, south-central Texas.

15. Time series (November 2008-December 2010) of selected physicochemical properties and geochemical constituents for Edwards aquifer groundwater wells sampled for the characterization of San Marcos Springs, south-central Texas 
16. Time series (November 2008-December 2010) of selected physicochemical properties and geochemical constituents for Trinity aquifer groundwater wells sampled for the characterization of San Marcos Springs, south-central Texas

17. Times series (November 2008-December 2010) of discharge at San Marcos Springs, selected physicochemical properties at San Marcos Springs orifices, and daily average rainfall in the vicinity of San Marcos Springs, south-central Texas.

18. Time series (November 2008-December 2010) of selected physicochemical properties and geochemical constituents for Edwards aquifer springs sampled for the characterization of San Marcos Springs, south-central Texas

19. Times series (November 2008-December 2010) of specific conductance and turbidity values at San Marcos Springs orifices, south-central Texas, preceding and in response to unsampled storms.

20. Specific conductance at San Marcos Springs, south-central Texas.

21. Relations among selected geochemical constituents for samples collected from Comal Spring 1, Hueco Spring A, and San Marcos Springs orifices, south-central Texas (November 2008-December 2010)

22. Time series (November 2008-December 2010) of stream discharge for the Blanco River, spring discharge at San Marcos Springs, and timing of sample collection used for PHREEOC geochemical modeling.

23. Relation between discharge at San Marcos Springs and the modeled proportion of discharge at Deep, Diversion, and Weissmuller Springs that is composed of stream recharge from the Blanco River based on PHREEOC inverse modeling results....

24. Relation between chloride concentration and deuterium isotopes for two-component mixing models showing proportional mixing between surface-water (stream recharge) and springwater endmembers and for samples collected in response to and subsequent to storm 3 (September 2010)

25. Time series (November 2008-December 2010) of San Marcos Springs daily mean discharge and estimated daily mean recharge to the Edwards aquifer from the Blanco River, south-central Texas

26. Relation between deuterium and oxygen isotopes for surface-water and spring samples, south-central Texas (November 2008-December 2010)

27. Relation between spring discharge (daily mean) for Comal, Hueco, and San Marcos Springs and selected physicochemical and geochemical constituents for samples collected from Comal Spring 1, Hueco Spring A, and San Marcos Springs orifices, south-central Texas (November 2008-December 2010).

\section{Tables}

1. Water-quality sampling and data-collection sites for hydrologic and geochemical characterization of San Marcos Springs, south-central Texas (November 2008-December 2010).

2. Number of samples analyzed for water quality for characterization of San Marcos Springs, south-central Texas (November 2008December 2010) 
3. Characteristics of sampled storms, antecedent moisture conditions, and hydrologic response in the vicinity of San Marcos Springs,

south-central Texas (November 2008-December 2010)

4. Characteristics of unsampled storms, antecedent moisture conditions, and hydrologic response in the vicinity of San Marcos Springs, south-central Texas (November 2008-December 2010)

5. Summary statistics for discharge, physicochemical properties, and selected geochemical constituents for surface-water, groundwater, and spring sites sampled during dry and wet hydrologic conditions in the vicinity of San Marcos Springs, south-central Texas (November 2008-December 2010)

6. Summary of PHREEQC inverse geochemical modeling results for San Marcos Springs, south-central Texas (2008-10)

7. Statistical relations for selected geochemical constituents with spring discharge for San Marcos Springs, Comal Springs, and Hueco Springs, south-central Texas (November 2008-December 2010)

\section{Conversion Factors and Abbreviations}

\section{Inch/Pound to SI}

\begin{tabular}{|c|c|c|}
\hline Multiply & By & To obtain \\
\hline \multicolumn{3}{|c|}{ Length } \\
\hline inch (in.) & 2.54 & centimeter $(\mathrm{cm})$ \\
\hline inch (in.) & 25.4 & millimeter $(\mathrm{mm})$ \\
\hline foot (ft) & 0.3048 & meter $(\mathrm{m})$ \\
\hline mile (mi) & 1.609 & kilometer $(\mathrm{km})$ \\
\hline mile (mi) & 1.609 & kilometer (km) \\
\hline yard (yd) & 0.9144 & meter $(\mathrm{m})$ \\
\hline \multicolumn{3}{|c|}{ Area } \\
\hline acre & 4,047 & square meter $\left(\mathrm{m}^{2}\right)$ \\
\hline acre & 0.004047 & square kilometer $\left(\mathrm{km}^{2}\right)$ \\
\hline square foot $\left(\mathrm{ft}^{2}\right)$ & 929.0 & square centimeter $\left(\mathrm{cm}^{2}\right)$ \\
\hline square foot $\left(\mathrm{ft}^{2}\right)$ & 0.09290 & square meter $\left(\mathrm{m}^{2}\right)$ \\
\hline square inch $\left(\mathrm{in}^{2}\right)$ & 6.452 & square centimeter $\left(\mathrm{cm}^{2}\right)$ \\
\hline square mile $\left(\mathrm{mi}^{2}\right)$ & 2.590 & square kilometer $\left(\mathrm{km}^{2}\right)$ \\
\hline \multicolumn{3}{|c|}{ Volume } \\
\hline gallon (gal) & 3.785 & liter $(\mathrm{L})$ \\
\hline gallon (gal) & 0.003785 & cubic meter $\left(\mathrm{m}^{3}\right)$ \\
\hline million gallons (Mgal) & 3,785 & cubic meter $\left(\mathrm{m}^{3}\right)$ \\
\hline acre-foot (acre-ft) & 1,233 & cubic meter $\left(\mathrm{m}^{3}\right)$ \\
\hline \multicolumn{3}{|c|}{ Flow rate } \\
\hline acre-foot per year (acre-ft/yr) & 1,233 & cubic meter per year $\left(\mathrm{m}^{3} / \mathrm{yr}\right)$ \\
\hline \multicolumn{3}{|c|}{ Hydraulic conductivity } \\
\hline foot per day $(\mathrm{ft} / \mathrm{d})$ & 0.3048 & meter per day $(\mathrm{m} / \mathrm{d})$ \\
\hline \multicolumn{3}{|c|}{ Hydraulic gradient } \\
\hline foot per mile ( $\mathrm{ft} / \mathrm{mi})$ & 0.1894 & meter per kilometer $(\mathrm{m} / \mathrm{km})$ \\
\hline
\end{tabular}




\section{SI to Inch/Pound}

\begin{tabular}{lcl}
\hline \multicolumn{1}{c}{ Multiply } & By & \multicolumn{1}{c}{ To obtain } \\
\hline centimeter $(\mathrm{cm})$ & Length & \\
millimeter $(\mathrm{mm})$ & 0.3937 & inch (in.) \\
meter $(\mathrm{m})$ & 0.03937 & inch (in.) \\
\hline & 3.281 & foot (ft) \\
\hline cubic meter $\left(\mathrm{m}^{3}\right)$ & Volume & \\
cubic centimeter $\left(\mathrm{cm}^{3}\right)$ & 264.2 & gallon (gal) \\
milliliter $(\mathrm{mL})$ & 0.06102 & cubic inch (in $\left.{ }^{3}\right)$ \\
liter $(\mathrm{L})$ & 0.035 & ounce, fluid (fl. oz) \\
liter $(\mathrm{L})$ & 33.82 & ounce, fluid (fl. oz) \\
liter $(\mathrm{L})$ & 2.113 & pint (pt) \\
liter $(\mathrm{L})$ & 1.057 & quart (qt) \\
\hline & 0.2642 & gallon (gal) \\
\hline cubic meter per second $\left(\mathrm{m}^{3} / \mathrm{s}\right)$ & Flow rate & \\
\hline & 70.07 & acre-foot per day (acre-ft/d) \\
\hline gram $(\mathrm{g})$ & Mass & \\
kilogram $(\mathrm{kg})$ & 0.3527 & ounce, avoirdupois (oz) \\
\hline
\end{tabular}

Temperature in degrees Celsius $\left({ }^{\circ} \mathrm{C}\right)$ may be converted to degrees Fahrenheit $\left({ }^{\circ} \mathrm{F}\right)$ as follows:

${ }^{\circ} \mathrm{F}=\left(1.8 x^{\circ} \mathrm{C}\right)+32$

Temperature in degrees Fahrenheit $\left({ }^{\circ} \mathrm{F}\right)$ may be converted to degrees Celsius $\left({ }^{\circ} \mathrm{C}\right)$ as follows:

${ }^{\circ} \mathrm{C}=\left({ }^{\circ} \mathrm{F}-32\right) / 1.8$

Vertical coordinate information is referenced to the North American Vertical Datum of 1988 (NAVD 88).

Horizontal coordinate information is referenced to the North American Datum of 1983 (NAD 83).

Altitude, as used in this report, refers to distance above the vertical datum.

Specific conductance is given in microsiemens per centimeter at 25 degrees Celsius $\left(\mu \mathrm{S} / \mathrm{cm}\right.$ at $\left.25^{\circ} \mathrm{C}\right)$.

Concentrations of chemical constituents in water are given either in milligrams per liter (mg/L) or micrograms per liter $(\mu \mathrm{g} / \mathrm{L})$. 


\section{Explanation of Isotope Units}

Per mil: A unit expressing the ratio of stable-isotope abundances of an element in a sample to those of a standard material. Per mil units are equivalent to parts per thousand. Stable-isotope ratios are computed as follows (Coplen and others, 2002):

$$
\delta \mathrm{X}=\left(\mathrm{R}_{\text {sample }} / \mathrm{R}_{\text {standard }}-1\right) \times 1,000 \text {, }
$$

where

$\delta$ is the "delta" notation,

$\mathrm{X}$ is the heavier stable isotope, and

$R$ is the ratio of the heavier, less abundant isotope to the lighter, stable isotope in a sample or standard.

The $\delta$ values for stable-isotope ratios discussed in this report are referenced to the following standard materials:

\begin{tabular}{lll}
\hline Element & \multicolumn{1}{c}{ R } & \multicolumn{1}{c}{ Standard identity and reference } \\
\hline Carbon & Carbon-13/carbon-12 & Vienna PeeDee Belemnite (Fritz and Fontes, 1980) \\
& & \\
Hydrogen & Hydrogen-2/hydrogen-1 & Vienna Standard Mean Ocean Water (Fritz and Fontes, 1980) \\
Oxygen & Oxygen-18/oxygen-16 & Vienna Standard Mean Ocean Water (Fritz and Fontes, 1980) \\
\hline
\end{tabular}

\section{Abbreviations}

$\begin{array}{ll}\mathrm{HCO}_{3} & \text { bicarbonate } \\ \mathrm{B} & \text { boron } \\ \mathrm{Br} & \text { bromide } \\ \mathrm{Ca} & \text { calcium } \\ \mathrm{Cl} & \text { chloride } \\ \delta^{13} \mathrm{C} & \text { delta carbon-13 } \\ \delta \mathrm{D} & \text { delta deuterium } \\ \delta^{18} \mathrm{O} & \text { delta oxygen-18 } \\ \mathrm{F} & \text { fluoride } \\ \mathrm{FNU} & \text { formazin nephelometric units } \\ \mathrm{Mg} & \text { magnesium } \\ \mathrm{Mg} / \mathrm{Ca} & \text { magnesium to calcium, molar ratio } \\ \mu \mathrm{g} / \mathrm{L} & \text { micrograms per liter } \\ \mu \mathrm{S} / \mathrm{cm} & \text { microsiemens per centimeter at 25 degrees Celsius } \\ \mathrm{mg} / \mathrm{L} & \text { milligrams per liter } \\ \mathrm{NCDC} & \text { National Climatic Data Center } \\ \mathrm{NWIS} & \text { National Water Information System } \\ \mathrm{NWS} & \text { National Weather Service } \\ \mathrm{NO} & \text { nitrate } \\ \mathrm{NO} & \text { nitrite } \\ \mathrm{NO}{ }_{2}+\mathrm{NO}{ }_{3} & \text { nitrite plus nitrate } \\ \mathrm{N} & \text { nitrogen } \\ \mathrm{K} & \text { potassium } \\ \mathrm{Na} & \text { sodium } \\ \mathrm{Sr}^{87} \mathrm{Sr} /{ }^{86} \mathrm{Sr} & \text { strontium } \\ \mathrm{Sr}^{\mathrm{CCa}} & \text { strontium isotope ratio } \\ \mathrm{SO}_{4} & \text { strontium to calcium, molar ratio } \\ & \text { sulfate } \\ & \end{array}$




\title{
Origin and Characteristics of Discharge at San Marcos Springs Based on Hydrologic and Geochemical Data (2008-10), Bexar, Comal, and Hays Counties, Texas
}

\author{
By MaryLynn Musgrove and Cassi L. Crow
}

\section{Abstract}

The Edwards aquifer in south-central Texas is a productive and important water resource. Several large springs issuing from the aquifer are major discharge points, popular locations for recreational activities, and habitat for threatened and endangered species. Discharges from Comal and San Marcos Springs, the first and second largest spring complexes in Texas, are used as thresholds in groundwater management strategies for the Edwards aquifer. Comal Springs is generally understood to be supplied by predominantly regional groundwater flow paths; the hydrologic connection of San Marcos Springs with the regional flow system, however, is less understood. During November 2008-December 2010, a hydrologic and geochemical investigation of San Marcos Springs was conducted by the U.S. Geological Survey (USGS) in cooperation with the San Antonio Water System. The primary objective of this study was to define and characterize sources of discharge from San Marcos Springs. During this study, hydrologic conditions transitioned from exceptional drought (the dry period, November 1, 2008 to September 8, 2009) to wetter than normal (the wet period, September 9, 2009 to December 31, 2010), which provided the opportunity to investigate the hydrogeology of San Marcos Springs under a wide range of hydrologic conditions. Water samples were collected from streams, groundwater wells, and springs at and in the vicinity of San Marcos Springs, including periodic (routine) sampling (every 3-7 weeks) and sampling in response to storms. Samples were analyzed for major ions, trace elements, nutrients, and selected stable and radiogenic isotopes (deuterium, oxygen, carbon, strontium). Additionally, selected physicochemical properties were measured continuously at several sites, and hydrologic data were compiled from other USGS efforts (stream and spring discharge). Potential aquifer recharge was evaluated from local streams, and daily recharge or gain/loss estimates were computed for several local streams. Local rainfall and recharge events were compared with physicochemical properties and geochemical variability at San Marcos Springs, with little evidence for dilution by local recharge.
Hydrologic and geochemical variability at San Marcos Springs was compared with that at Comal Springs and Hueco Springs. A small range of variability was observed at Comal Springs, and a large range was observed at Hueco Springs; variability at San Marcos Springs was intermediate. Comal Springs and Hueco Springs are representative of two endmember Edwards aquifer spring types, with Hueco Springs predominantly affected by local flowpaths and locally sourced recharge and Comal Springs predominantly affected by regional flowpaths and regionally sourced recharge. The geochemistry of discharge at San Marcos Springs from three of its orifices - Deep, Diversion, and Weissmuller Springsdiffered among the orifices; these differences in geochemistry are indicative of differences in the sources and flow paths of recharge and groundwater supplying the springs. During the dry period, the geochemistry of Deep Spring indicates that it was affected by a small component of saline groundwater. The geochemistry of Deep Spring was not responsive to changes in hydrologic conditions from the dry period to the wet period, indicating that Deep Spring is likely dominated by regional and less-variable flow paths. Diversion Spring was more responsive to changes in hydrologic conditions, indicating that Diversion Spring was affected by some changes in discharge sources. From the dry period to the wet period, the geochemistry of Diversion Spring became more like that at Deep Spring; the nature of the geochemical changes indicates that increased discharge included an increased component of saline groundwater. Weissmuller Spring was sampled only during the wet period; its geochemistry was similar to that of Diversion Spring, indicating that Weissmuller and Diversion Springs are likely supplied by common flow paths.

Geochemical models (using PHREEQC) indicate that a small amount of saline groundwater (generally less than 1 percent), in addition to a dominant component of regional groundwater flow, is needed to account for the composition of water from Deep, Diversion, and Weissmuller Springs. Potential sources of saline groundwater are the downdip Edwards aquifer saline zone and the Trinity aquifer; while both sources are hydrologically and geochemically plausible, model results indicate that mixing with groundwater from the 
Edwards aquifer saline zone is likely a better geochemical fit. Little local recharge occurred during the dry period. Geochemical model results for the wet period yielded different proportions of local recharge sources (the Blanco River) to discharge from San Marcos Springs ranging from 0 to less than 30 percent; the proportion was smaller for Deep Spring than for Diversion Spring, which is consistent with the nominal response of Deep Spring to changes in hydrologic conditions. In response to storm events, when focused recharge of dilute surface water is likely to occur, the geochemical response at San Marcos Springs was minor; for example, the modeled proportion of local surface-water recharge contributing to Diversion Spring was mostly less than 10 percent directly following storms and for several subsequent months. These results place further constraints on estimates using PHREEQC and suggest that the proportion of local recharge contributing to discharge at San Marcos Springs is likely on the order of no more than 10 percent.

The results of this study indicate that discharge at San Marcos Springs is dominated by regional recharge sources and flow paths, even during wet hydrologic conditions when aquifer recharge is likely occurring from local streams. Local surface-water recharge sources do not strongly influence the geochemistry of San Marcos Springs discharge. Knowledge of recharge sources to San Marcos Springs and how they vary spatially and temporally is useful for water-resource management strategies and for understanding geochemical and hydrologic processes that affect discharge at San Marcos Springs.

\section{Introduction}

The San Antonio segment of the Edwards aquifer (hereinafter, Edwards aquifer) in south-central Texas is one of the most productive aquifers in the world and is a designated sole-source aquifer that is the largest water supply for more than two million people in a rapidly urbanizing region (Sharp and Banner, 1997; U.S. Environmental Protection Agency, 2006). Springs issuing from the Edwards aquifer provide habitat for several threatened and endangered species (Edwards Aquifer Research and Data Center, 2010), serve as locations for recreational activities, and supply downstream users. Comal Springs and San Marcos Springs, the first and second largest spring complexes in Texas, are major discharge points for the Edwards aquifer (Brune, 1975) (fig. 1). Spring discharges from the Comal and San Marcos Springs complexes, along with water-table altitudes in the Bexar County index well (hereinafter, J-17; fig. 1), are used as thresholds for enacting various water management strategies in the San Antonio area (Texas Legislature Online, 2007). A comprehensive understanding of the hydrogeology and sources of water to Comal Springs and San Marcos Springs is needed for effective aquifer management. Discharge at Comal Springs is generally understood to be predominantly supplied by regional flow paths originating in the western part of the aquifer (Puente, 1976; Guyton and Associates, 1979; LBG-Guyton Associates, 2004; Johnson and Schindel, 2008). Although San Marcos Springs has been hypothesized to be supplied by both regional and local recharge sources (Guyton and Associates, 1979; Ogden and others, 1986), the hydrologic interconnection of San Marcos Springs with the regional Edwards aquifer flow system is uncertain.

During November 2008-December 2010, the U.S. Geological Survey (USGS), in cooperation with the San Antonio Water System, collected and analyzed hydrologic and geochemical data in Bexar, Comal, and Hays Counties, Tex. (fig. 1). The primary objective of the study was to identify and characterize sources of recharge and groundwater supplying San Marcos Springs. During the study, climatic and hydrologic conditions underwent a transition from exceptional drought (U.S. Drought Monitor, 2011) to wetter than normal. Between November 1, 2008 and September 8, 2009 is referred to as the "dry period," and the period between September 9, 2009 and December 31, 2010 is referred to as the "wet period." Rainfall and hydrologic conditions, including surface-water recharge and spring discharge during the period of the study, are described in detail in the Climatic and Hydrologic Conditions section of this report. Collection of routine and storm-associated water samples from streams, groundwater wells, and springs over the 25 months of the study provided an opportunity to investigate the hydrogeology of San Marcos Springs under a wide range of climatic and hydrologic conditions and the response of the karst system to drought and post-drought conditions.

The Edwards aquifer is karst, in which soluble host rocks have dissolved preferentially to form large interconnected voids and conduits (White, 1988). Most groundwater storage in karst aquifers occurs within the bedrock matrix (primary pores and bedding planes), but most transport occurs within the secondary conduits, which often dominate groundwater flow where present (White, 2002). Transport of water through the primary aquifer matrix is typically diffuse and much slower (Atkinson, 1977; Martin and Screaton, 2001; Desmarais and Rojstaczer, 2002). As a result, karst aquifers tend to be heterogeneous with large variability and rapid changes in aquifer recharge, flow, and discharge rates. Karst springs are integrators of input from various sources and processes that occur along flow paths to the spring and, as such, are ideal sites for studying aquifer processes and surfacewater/groundwater interaction (Quinlan, 1989). Karst springs that are dominantly supplied by focused recharge (quick flow) moving through a well-developed conduit system can be highly variable in discharge quantity and quality. Karst springs dominantly supplied by matrix (diffuse) flow (slow flow) tend to exhibit less temporal variability in spring discharge and geochemistry; recharge moves more slowly along diffuse flow paths than it does in conduits, and has more opportunity to interact with the rock matrix and mix with matrix groundwater (White, 1988; Ford and Williams, 2007). In karst aquifers, changes in climatic and hydrologic conditions directly affect 


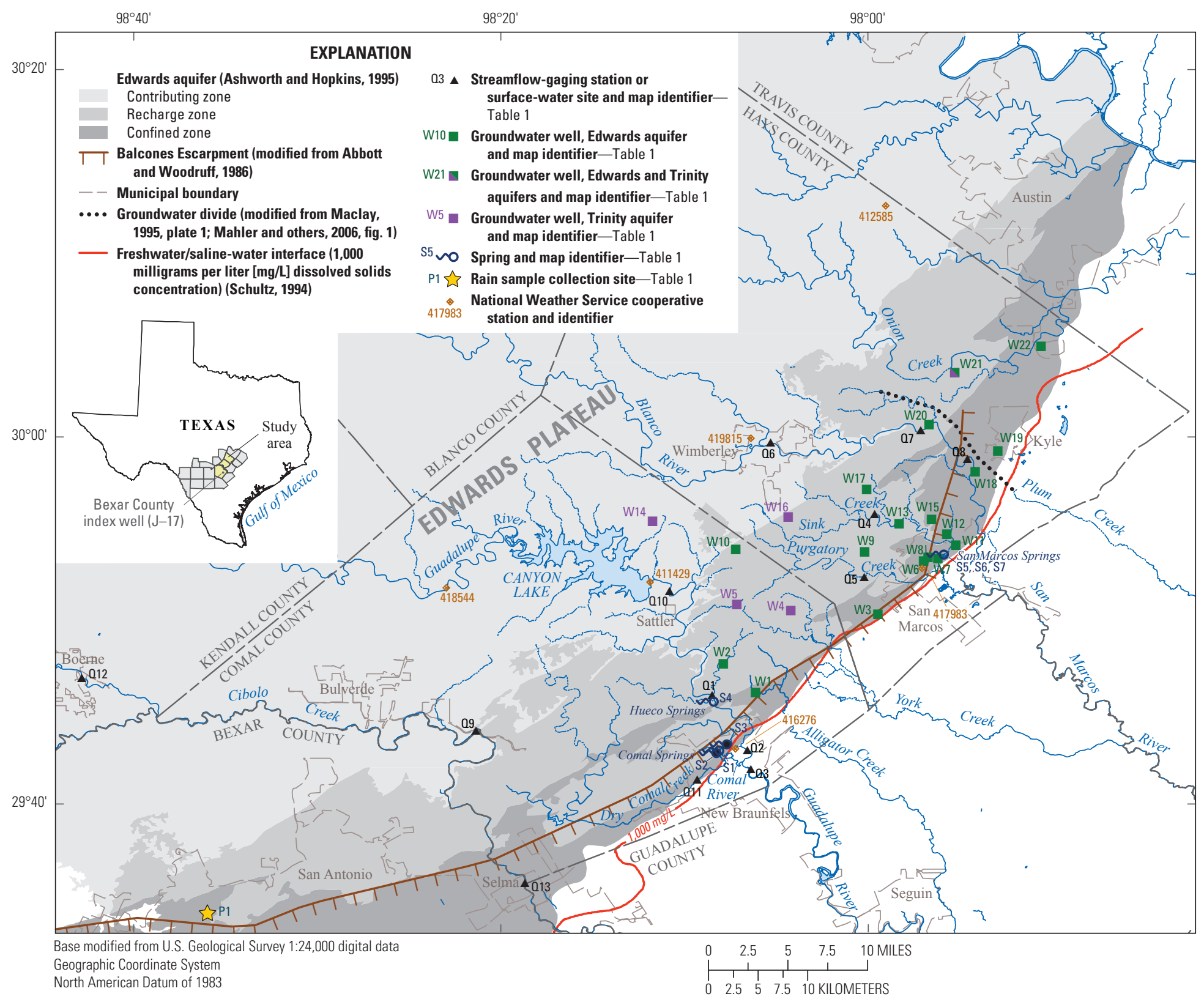

Figure 1. Study area and locations of water-quality sampling and data-collection sites for hydrologic and geochemical characterization of San Marcos Springs, south-central Texas. 
the aquifer through processes including dilution of recharge, surface-water/groundwater mixing, the extent of water-rock interaction, and corresponding aquifer geochemistry. This study evaluates hydrologic and geochemical processes that affect discharge at San Marcos Springs and provides insight into the origin and characteristics of discharge at San Marcos Springs and how they vary spatially and temporally.

\section{Purpose and Scope}

The purpose of this report is to (1) describe hydrologic and geochemical data for November 2008-December 2010 from streams, groundwater wells, and springs in parts of Bexar, Comal, and Hays Counties, Tex.; (2) evaluate changes in hydrologic and geochemical data for San Marcos Springs and other hydrologic features in parts of Bexar, Comal, and Hays Counties in response to changes in hydrologic conditions during the dry and wet periods; and (3) synthesize the findings to identify and characterize sources of recharge and groundwater supplying San Marcos Springs.

\section{Hydrogeologic Setting}

The karstic Edwards aquifer developed in Lower Cretaceous limestone and dolomite rocks of the Edwards Group (Person and Kainer Formations) (Rose, 1972) and the Georgetown Formation. The aquifer is present in a narrow band along the Balcones fault zone, which is characterized by a series of high-angle en echelon down-to-the-coast normal faults within a series of fault blocks that trend southwest to northeast (Barker and Ardis, 1996). The fault blocks, and their subsequent erosion and dissolution, are major factors affecting groundwater flow within the Edwards aquifer. Most recharge to the Edwards aquifer occurs in the recharge zone, where the porous and permeable Edwards Group outcrops. Streams flowing south and east toward the Gulf of Mexico drain the Edwards Plateau and lose most or all of their flows into the faulted and fractured limestone as they cross the recharge zone, supplying from 60 to 80 percent of aquifer recharge (Klemt and others, 1979; Maclay and Land, 1988; Thorkildsen and McElhaney, 1992; Ockerman, 2005). The majority of recharge occurs west of Bexar County with additional recharge occurring in Bexar, Comal, and Hays Counties (fig. 1).

Regional groundwater flow is generally eastward to discharge points in Bexar County, mainly municipal water-supply wells. Water not discharged to wells continues generally toward the northeast along and parallel to the Balcones Escarpment, the surface expression of the Balcones fault zone (McKinney and Sharp, 1995), to discharge points in Comal and Hays Counties, primarily Comal Springs and San Marcos Springs (Maclay and Land, 1988) (fig. 1). San Marcos Springs is downgradient from Comal Springs (fig. 1), and regional groundwater flow paths that supply discharge to Comal Springs also supply discharge to San Marcos Springs (Johnson and Schindel, 2008). Depending on the magnitude of displacement, faults can either facilitate or impede flow of groundwater between adjacent fault blocks. Faults that juxtapose rocks of the Edwards aquifer against those of the underlying Trinity aquifer could allow groundwater from the Trinity aquifer to enter the Edwards aquifer, resulting in subsurface, interaquifer flow (Lindgren and others, 2004). The downdip limit of potable water in the Edwards aquifer, the freshwater/saline-water interface, is defined by a dissolved solids concentration of 1,000 milligrams per liter (mg/L) (Schultz, 1994; Groschen and Buszka, 1997), which also defines the transition from a zone of more active flow with fresh groundwater to the downdip zone of less active flow with saline groundwater.

Comal, San Marcos, and Hueco Springs are karst springs associated with large-displacement faults (fig. 2). Comal Springs is a complex of springs that issue from numerous solution cavities along a 1,500-foot (ft) section of the Comal Springs Fault (Puente, 1976), a normal fault with as much as $500 \mathrm{ft}$ of offset (Maclay and Land, 1988). Longterm discharge from the Comal Springs complex (USGS station (08168710) (1927-2010) has ranged from 0 to 534 cubic feet per second $\left(\mathrm{ft}^{3} / \mathrm{s}\right)$ with an average value of $292 \mathrm{ft}^{3} / \mathrm{s}$ (U.S. Geological Survey, 2011); discharge during the study period (November 2008-December 2010) ranged from 158 to $391 \mathrm{ft}^{3} / \mathrm{s}$ with an average value of $293 \mathrm{ft}^{3} / \mathrm{s}$ (median of $306 \mathrm{ft}^{3} / \mathrm{s}$ ) (U.S. Geological Survey, 2011). Water discharging from Comal Springs is impounded by a low-head dam that forms a small lake in Landa Park in New Braunfels, Tex. About 25 percent of the discharge from the Comal Springs complex emerges from three large spring orifices, including Comal Spring 1, in the upthrown block of the fault; the remaining discharge emerges from numerous small orifices beneath the lake in the downthrown block of the fault (Ogden and others, 1986; LBG-Guyton Associates, 2004), which sits at an average altitude of about $623 \mathrm{ft}$ (Guyton and Associates, 1979). The water flows over the dam and forms the headwaters of a 2-mile- (mi-) long tributary to the Guadalupe River known as the Comal River.

Hueco Springs is located about $5 \mathrm{mi}$ north-northwest of Comal Springs, in the outcrop area of the Edwards aquifer (figs. 1 and 2). The springs are located just south of the Hueco Springs Fault, which has $380-400 \mathrm{ft}$ of offset in the vicinity of the springs. Long-term discharge from the Hueco Springs complex (USGS station 08168000) (2002-2010) has ranged from 1.3 to $148 \mathrm{ft}^{3} / \mathrm{s}$ with an average value of $53 \mathrm{ft}^{3} / \mathrm{s}$; discharge during the study period (November 2008-December 2010) ranged from 1.3 to $121 \mathrm{ft}^{3} / \mathrm{s}$ with an average discharge of $44 \mathrm{ft}^{3} / \mathrm{s}$ (median of $40 \mathrm{ft}^{3} / \mathrm{s}$ ) (U.S. Geological Survey, 2011). Hueco Springs comprises two spring orifices that emerge from the alluvium along the west side of the Guadalupe River and then flow into the Guadalupe River. With an altitude of about $652 \mathrm{ft}$, Hueco Springs is $29 \mathrm{ft}$ higher than the average altitude of Comal Springs and about $78 \mathrm{ft}$ higher than the average altitude of San Marcos Springs (Guyton and Associates, 1979). Discharge from Hueco Springs flows south along an approximately 0.3 -mi-long channel that empties into the Guadalupe River. 


\section{EXPLANATION}

Upper confining units (Ashworth and Hopkins, 1995)

Edwards aquifer (Ashworth and Hopkins, 1995)

Trinity aquifer (Ashworth and Hopkins, 1995)

Fault-Dashed where approximately

located. Arrow indicates relative

direction of movement

_..-Stream-Dashed where ephemeral

On Spring

Base modified from U.S. Geological Survey digital data, 1:24,000 Universal Transverse Mercator projection, zone 14

Datum, North American Datum of 1983

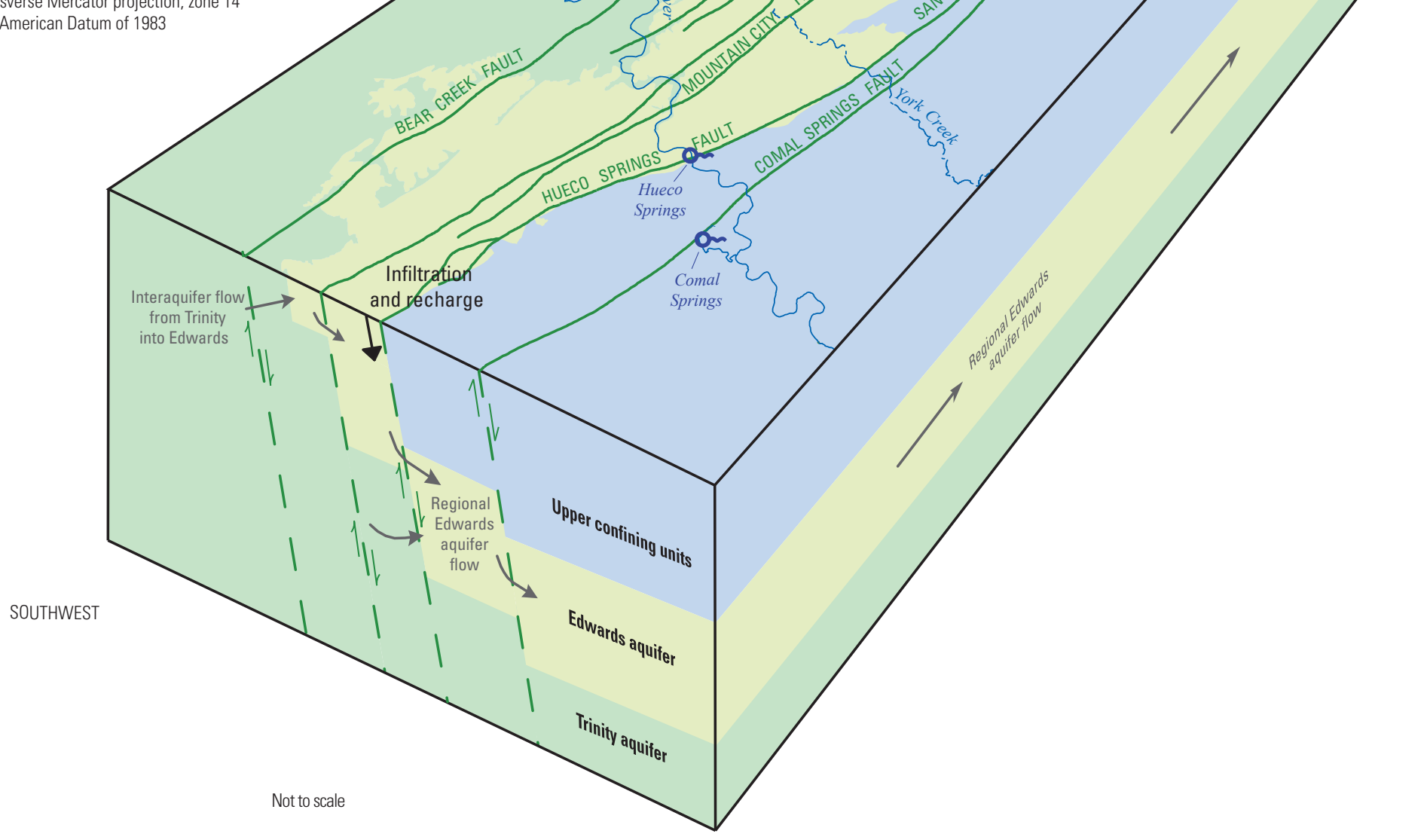

Figure 2. Idealized block diagram of the Edwards aquifer between Comal Springs Fault and Bear Creek Fault in the vicinity of Comal, Hueco, and 
San Marcos Springs is a complex of springs that issue from the San Marcos Springs Fault (figs. 3 and 4), a normal fault with as much as $470 \mathrm{ft}$ of offset (LBG-Guyton Associates, 2004) that juxtaposes the Edwards Group against younger upper confining units. Long-term discharge from the San Marcos Springs complex (USGS station 08170000) (1955-2010) has ranged from 46 to $451 \mathrm{ft}^{3} / \mathrm{s}$ with an average value of $174 \mathrm{ft}^{3} / \mathrm{s}$ (U.S. Geological Survey, 2011); discharge during the study period (November 2008-December 2010) ranged from 83 to $270 \mathrm{ft}^{3} / \mathrm{s}$ with an average discharge of $160 \mathrm{ft}^{3} / \mathrm{s}$ (median of $176 \mathrm{ft}^{3} / \mathrm{s}$ ) (U.S. Geological Survey, 2011). LBG-Guyton Associates (2004) estimated that approximately 25 percent of the total discharge from San Marcos Springs emerges from well-defined orifices and the remaining 75 percent from sand boils. Water discharging from San Marcos Springs is impounded by a concrete dam to form Spring Lake (fig. 4) and then spills over two outflow structures. The two channels converge downstream from the outflow structures as the headwaters of the San Marcos River. Because San Marcos Springs is $49 \mathrm{ft}$ lower in altitude than is Comal Springs, downgradient aquifer flow of water past Comal Springs to San Marcos Springs likely occurs (Guyton and Associates, 1979; McKinney and Sharp, 1995).

\section{Summary of Previous Studies}

Previous studies provide insight into the hydrology and geochemistry of the regional Edwards aquifer and Comal, San Marcos, and Hueco Springs. Most notably, studies focused on the hydrogeology of San Marcos Springs have described a combination of regional and local sources supplying spring discharge. Based on a comparison of spring flow curves, it has been previously noted that the correlation between water-table altitudes for well J-17 and San Marcos Springs discharge is not as well correlated as that between $\mathrm{J}-17$ and Comal Springs; additionally, the relation between discharge at Comal Springs and at San Marcos Springs indicates that they might have differences in discharge sources (LBG-Guyton Associates, 2004; Johnson and Schindel, 2008).

Studies of Comal Springs have identified mostly regional sources for spring discharge. Puente (1976) used relations between water levels, spring discharge, and stream discharge to develop statistical correlations and concluded that Comal Springs was supplied primarily by flow from the regional aquifer to the west and southwest and secondarily by local recharge. Rothermel and Ogden (1986) considered several lines of evidence that implied a lack of local recharge to Comal Springs including negligible turbidity during and after storms, inability to trace dye from local sinks to the springs, low coefficients of variation for different geochemical constituents, and a mean annual water temperature that was warmer than the mean annual air temperature. McKinney and Sharp (1995), in an investigation of the feasibility of springflow augmentation, used information from previous studies to conclude that Comal Springs is supplied by regional flow with long residence times from the western part of the aquifer, with little to no evidence for local recharge sources. Otero (2007) used geologic, hydrologic, and geochemical data to identify and characterize three separate flow paths conveying water to Comal Springs.

Studies of Hueco Springs have identified a mostly local recharge source for spring discharge (Guyton and Associates, 1979; Ogden and others, 1986), which might also include some unknown percentage of water derived from the Trinity aquifer (LBG-Guyton Associates, 1995; Lindgren and others, 2004). Hueco Springs is the only large spring in the Edwards aquifer that is located in the outcrop area and has been hypothesized to have a much smaller contributing area than do the other major springs (Guyton and Associates, 1979; Maclay, 1995; Lindgren and others, 2004). Hueco Springs has a smaller mean discharge than do other major springs in the Edwards aquifer and generally does not flow during extended droughts, which is consistent with the hypothesis of a smaller contributing area and a local recharge source possibly comprising the upper part of the Dry Comal Creek Basin and the Guadalupe River Basin recharge areas west of the river. Some water from Hueco Springs might also be sourced from the main part of the aquifer between San Antonio and Comal Springs under wet hydrologic conditions (Guyton and Associates, 1979).

Studies of San Marcos Springs have described a combination of regional and local sources for spring discharge. Pearson and others (1975) concluded, on the basis of tritium results, that approximately 35 percent of the discharge from San Marcos Springs might come from local recharge in areas east of Bexar County, in Comal and Hays Counties. Puente (1976), using statistical correlations between water levels, spring discharge, and stream discharge, concluded that San Marcos Springs is supplied by a combination of regional flow from the Comal Springs area and local recharge in northern Comal and Hays Counties. Using historical tritium concentrations and spring discharge correlations, Guyton and Associates (1979) concluded that roughly 55-60 percent of discharge from San Marcos Springs originates from regional groundwater flowing past Comal Springs to San Marcos Springs from the southwest. Ogden and others (1985a, 1985b, 1986) concluded from an integrated study of chemistry and hydrologic data that the springs in the southern part of Spring Lake are supplied by regional flow from the Comal Springs Fault Block and that those in the northern part of the lake are supplied by local recharge from the Blanco River and Sink Creek; they proposed that the northern and southern parts of the lake are separated by faults or a "pressure boundary" that might shift in response to changing flow conditions. Wanakule (1988) accounted for a weaker correlation between the water-table altitude in well J-17 and discharge from San Marcos Springs, relative to discharge from Comal Springs, on the basis of the longer flow paths and the influence of local recharge from the Blanco River Basin. McKinney and Sharp (1995) concluded that, although supplied mainly by regional flow, a component of recharge to San Marcos Springs might 
$\boldsymbol{A}$

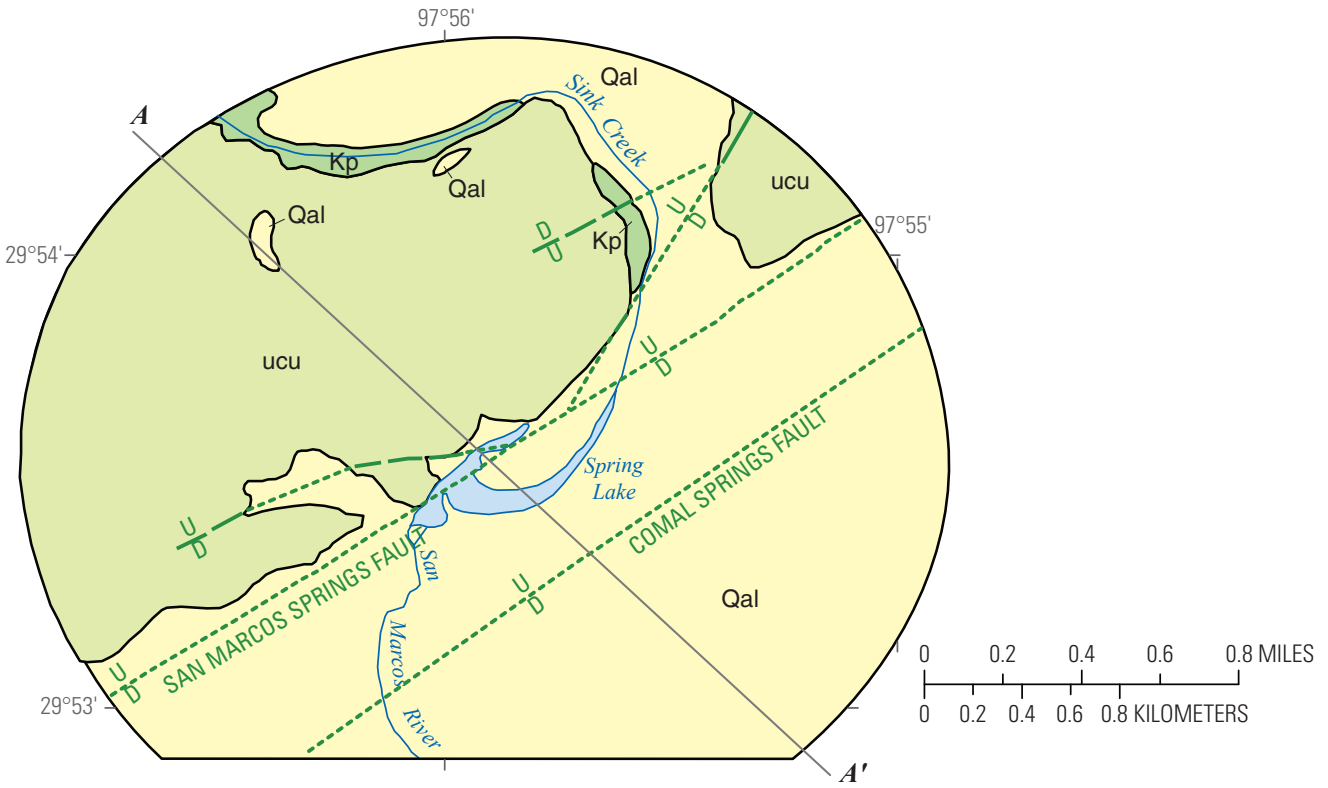

Base modified from Guyton and Associates (1979) Universal Transverse Mercator projection, Zone 14 North American Datum of 1983

\section{EXPLANATION}

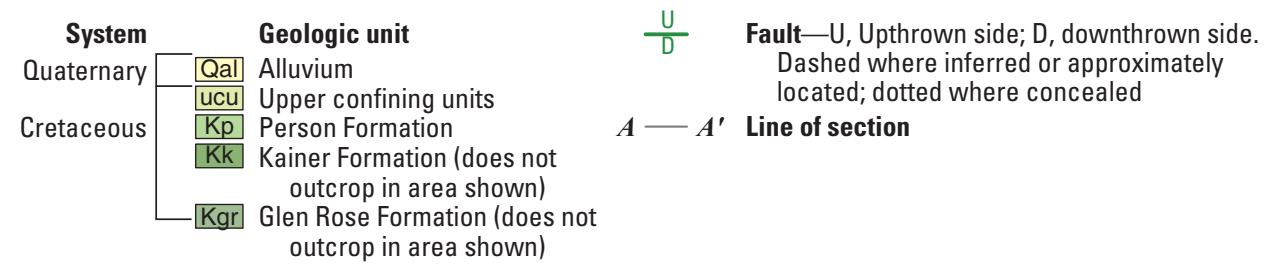

$\boldsymbol{B}$

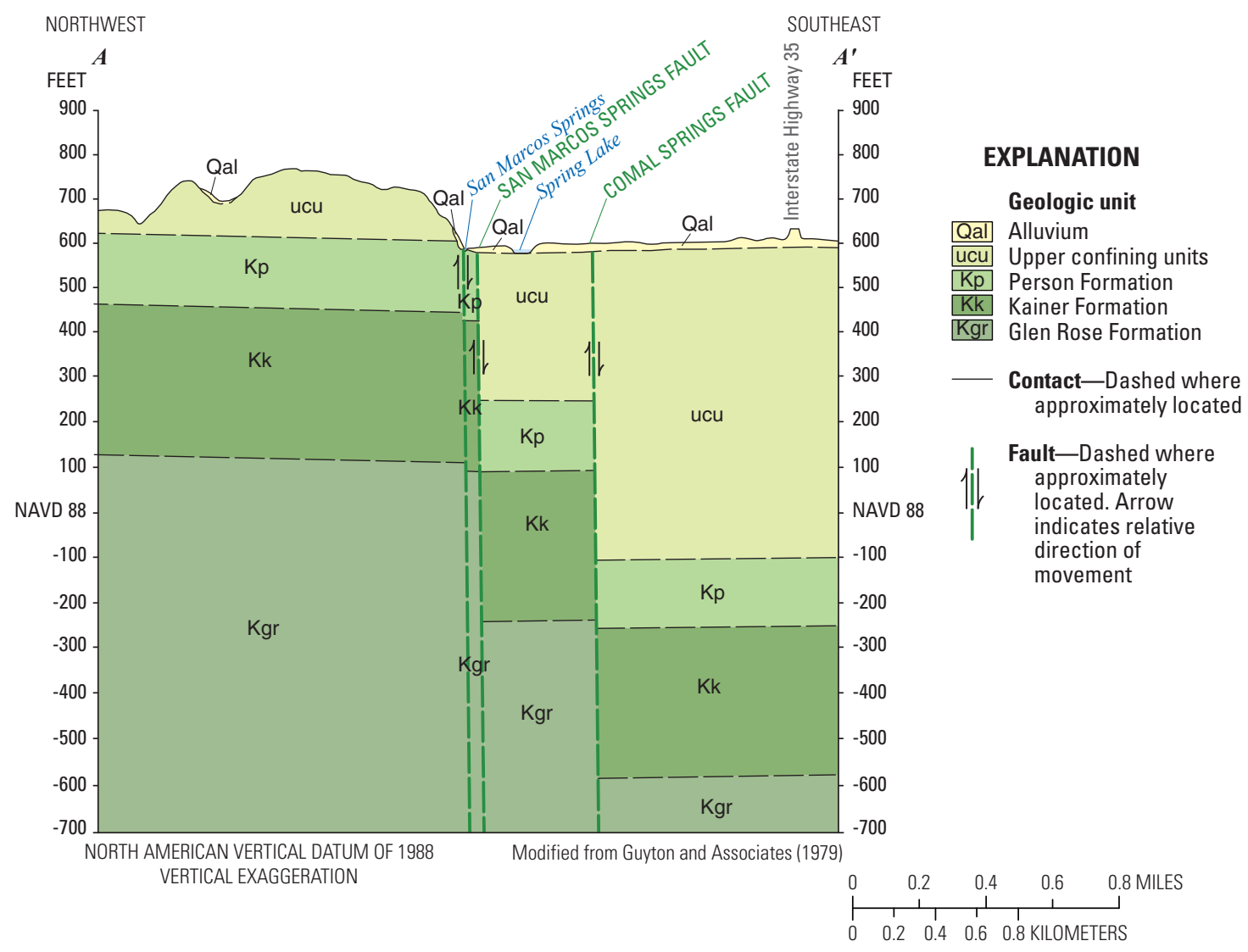

Figure 3. San Marcos Springs, Hays County, south-central Texas. A, Surface geology. B, Geologic section. 


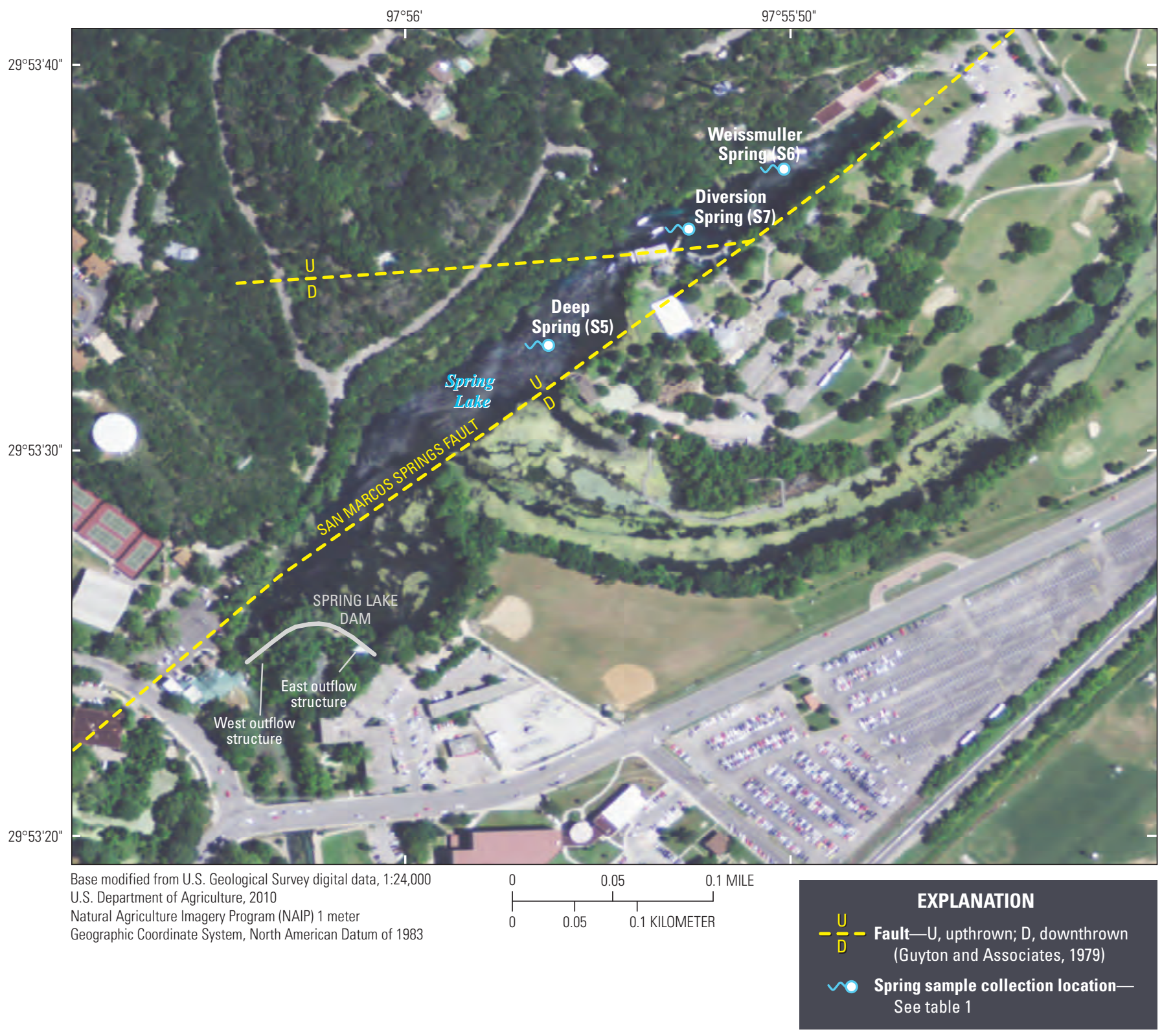

Figure 4. San Marcos Springs complex, Hays County, south-central Texas.

include local recharge sources 10-30 mi west of the springs. LBG-Guyton Associates (2004) concluded that San Marcos Springs is located at the end of the regional groundwater flow path in Edwards aquifer fault blocks on the upthrown side of the Comal Springs Fault that is bypassing discharge to Comal Springs; they also concluded that San Marcos Springs might be supplied by local recharge sources from the Blanco River and associated drainage basins in Hays County. Johnson and Schindel (2008) concluded that discharge from San Marcos Springs is sourced primarily from regional flow paths from the western part of the aquifer (more than 90 percent of the discharge during low-flow conditions), whereas local recharge sources such as the Blanco River, Sink Creek, Cibolo Creek, the Guadalupe River, and Dry Comal Creek contribute a small percentage of water that most likely discharges from springs in the northern part of Spring Lake.

Dye tracing has been used in previous studies to assess flow paths to San Marcos Springs. Results from dye tracing efforts by Ogden and others (1986) indicate that, during below-average discharge conditions at San Marcos Springs (approximately $140 \mathrm{ft}^{3} / \mathrm{s}$ ), groundwater moved from Ezell's Cave, located approximately 2 mi southwest of Spring Lake, to spring orifices in the southern part of Spring Lake within 11 days; the dye was not detected in the spring orifices in the 
northern part of Spring Lake. The Edwards Aquifer Authority conducted numerous tracer tests near San Marcos Springs in 2002 through 2005 under a range of flow conditions, which confirmed recharge and groundwater flow from a number of sites to the south, southwest, and west of San Marcos Springs to both northern and southern spring orifices; their results indicate that a highly transmissive groundwater flow path with groundwater velocities of approximately $1,400 \mathrm{ft}$ per day exists parallel to the Hueco Springs Fault (Johnson and Schindel, 2008). They delineated flow paths from locations to the southwest and west of San Marcos Springs during belowaverage to average discharge conditions (approximately 168$196 \mathrm{ft}^{3} / \mathrm{s}$ ) in 2005 that had relatively long traveltimes and were detected at spring orifices in both the southern and northern parts of Spring Lake (Johnson and Schindel, 2008). Ogden and others (1986) introduced dye into Rattlesnake Cave, located approximately $4,000 \mathrm{ft}$ to the northeast of Spring Lake, during below-average discharge conditions at San Marcos Springs (approximately $60 \mathrm{ft}^{3} / \mathrm{s}$ ), and the dye was detected in spring orifices in both the northern and southern parts of Spring Lake 40 days after injection. Johnson and Schindel (2008) replicated the Rattlesnake Cave dye-tracing test during average discharge conditions (approximately $150 \mathrm{ft}^{3} / \mathrm{s}$ ), and the dye was detected in spring orifices in both the northern and southern parts of Spring Lake approximately 3 days after injection. Dye introduced by Ogden and others (1986) into Tarbuttons Showerbath Cave, located approximately $20 \mathrm{ft}$ from the Blanco River and approximately 6 mi north of Spring Lake, was continually detected for a 6 -week period following a year-long traveltime at spring orifices in both the northern and the southern parts of Spring Lake; discharge at San Marcos Springs ranged from 100 to $218 \mathrm{ft}^{3} / \mathrm{s}$ during the year between dye injection and detection with an average discharge of $141 \mathrm{ft}^{3} / \mathrm{s}$. The year-long traveltime was viewed skeptically at the time (Ogden and others, 1986) and indicates that flow paths between the Blanco River and San Marcos Springs might not be particularly rapid or direct. Based on these results, the role of the Blanco River in supplying recharge to San Marcos Springs was unclear, although the potentiometric surface is consistent with groundwater movement from the Blanco River towards San Marcos Springs. On the basis of a series of more recent dye-tracing tests conducted during a similar timeframe as the current study (2008-10; Johnson and others, 2012), the Edwards Aquifer Authority confirmed flow paths to San Marcos Springs from the Blanco River but noted that dye-tracing tests indicated that groundwater gradients are relatively steep directly south of the Blanco River and become more shallow closer to San Marcos Springs and, as a result, flow paths to San Marcos Springs are likely slow. Their results also indicate that Sink Creek might be a minor local recharge source to San Marcos Springs (Johnson and others, 2012). Their groundwater velocity results indicate that most San Marcos Springs discharge originates from the southwest along regional flow paths (Johnson and others, 2012).

\section{Methods of Investigation}

\section{Study Design}

A multiphase approach was used to evaluate the water chemistry from San Marcos Springs, the streams that potentially contribute to its recharge, nearby groundwater, and other nearby springs (Comal and Hueco Springs) and to characterize sources of discharge at San Marcos Springs. Hydrologic and geochemical data were collected from streams (surface water), groundwater wells (groundwater), and springs (springwater) in the study area during November 2008 through December 2010. Samples were collected from 5 streams, 21 wells, 3 orifices of San Marcos Springs, and orifices of Comal and Hueco Springs (fig. 1; table 1). Twenty-four rain samples (from one site in northern San Antonio) also were collected for stable isotope analysis (fig. 1, map identifier P1). Continuous water-quality monitors were installed at one stream site, in two Edwards aquifer wells, and in three orifices at San Marcos Springs. Water-table altitude was continuously measured in the two wells. Three streamflow-gaging stations were installed, and continuous gage height was recorded; stage-discharge ratings were developed for two of the stations to compute continuous discharge data. Three spring orifices at San Marcos Springs were selected to be representative of larger springs at the spring complex on the basis of comparison with historical data (Ogden and others, 1985a, 1985b, 1986)

Synoptic and periodic sampling of surface water and groundwater was conducted to evaluate spatial and temporal hydrologic variability in the study area. A broad synoptic sampling effort in December 2008 characterized surface water and groundwater at 5 stream sites, 19 groundwater sites, and 7 spring orifices at Comal, Hueco, and San Marcos Springs (table 1). A subset of these sites was selected for periodic (routine) sampling to characterize changes in water quality and in response to hydrologic conditions, with samples collected approximately every 3-7 weeks throughout the study period (no samples were collected between March and May 2010) (table 2). Routine samples were collected from two stream sites, eight groundwater wells (three with relatively short sampling periods that ended in February 2010), one spring orifice each at Comal and Hueco Springs, and three spring orifices at San Marcos Springs (table 2; fig. 5). All samples were analyzed for major ions, trace elements, nutrients, and selected stable and radiogenic isotopes (deuterium, oxygen, carbon, and strontium) as described by Crow (2012). Because discharge at the stream and spring sites varied in response to rainfall, routine samples should not be assumed to represent base-flow conditions. It should also be noted that spring discharge values for Comal, Hueco, and San Marcos Springs represent discharge for the spring complexes, whereas physicochemical and geochemical data were collected from individual spring orifices. 
Table 1. Water-quality sampling and data-collection sites for hydrologic and geochemical characterization of San Marcos Springs, south-central Texas

(November 2008-December 2010)

[NAD 83, North American Datum of 1983; NAVD 88, North American Vertical Datum of 1988; dd, degrees; mm, minutes; ss, seconds; --, not available; N/A, not applicable; X, open hole; W, walled; S, screened; QW, water-quality samples (routine and [or] storm); WL, continuous groundwater altitude; M, continuous water-quality monitor; G, continuous gage height; Q, continuous gage height and continuous discharge; TSU, Texas State University; do, ditto; USGS, U.S. Geological Survey]

\begin{tabular}{|c|c|c|c|c|c|c|c|c|c|c|c|}
\hline $\begin{array}{l}\text { Map iden- } \\
\text { tifier (fig. 1) }\end{array}$ & $\begin{array}{c}\text { U.S. Geological } \\
\text { Survey station } \\
\text { number }\end{array}$ & $\begin{array}{c}\text { U.S. Geological } \\
\text { Survey station } \\
\text { name (surface- } \\
\text { water sites) or } \\
\text { State well number } \\
\text { (groundwater } \\
\text { wells and springs) }\end{array}$ & Short name & $\begin{array}{l}\text { Latitude, in } \\
\text { dd mm ss } \\
\text { (NAD 83) }\end{array}$ & $\begin{array}{l}\text { Longitude, } \\
\text { in dd mm ss } \\
\text { (NAD 83) }\end{array}$ & $\begin{array}{l}\text { Altitude of } \\
\text { land surface } \\
\text { (NAVD 88) } \\
\text { (feet) }\end{array}$ & $\begin{array}{c}\text { Contributing } \\
\text { aquifer(s) }\end{array}$ & $\begin{array}{l}\text { Well } \\
\text { depth } \\
\text { (feet) }\end{array}$ & $\begin{array}{c}\text { Well open } \\
\text { interval } \\
\text { (feet) }\end{array}$ & $\begin{array}{c}\text { Well } \\
\text { completion } \\
\text { type }\end{array}$ & $\begin{array}{l}\text { Data } \\
\text { type(s) }\end{array}$ \\
\hline \multicolumn{12}{|c|}{ Surface-water sites } \\
\hline Q1 & 08167990 & $\begin{array}{l}\text { Guadalupe River at } \\
\text { River Road near } \\
\text { Sattler, Tex. }\end{array}$ & $\begin{array}{r}\text { Guadalupe at } \\
\text { River Road }\end{array}$ & $29^{\circ} 45^{\prime} 55^{\prime \prime}$ & $98^{\circ} 08^{\prime} 31^{\prime \prime}$ & 640 & $\mathrm{~N} / \mathrm{A}$ & N/A & $\mathrm{N} / \mathrm{A}$ & $\mathrm{N} / \mathrm{A}$ & QW \\
\hline Q2 & 08168500 & $\begin{array}{c}\text { Guadalupe River } \\
\text { above Comal } \\
\text { River at New } \\
\text { Braunfels, Tex. }\end{array}$ & $\begin{array}{l}\text { Guadalupe } \\
\text { above } \\
\text { Comal }\end{array}$ & $29^{\circ} 42^{\prime} 54^{\prime \prime}$ & $98^{\circ} 06^{\prime} 36^{\prime \prime}$ & 587 & $\mathrm{~N} / \mathrm{A}$ & N/A & $\mathrm{N} / \mathrm{A}$ & $\mathrm{N} / \mathrm{A}$ & $\mathrm{Q}, \mathrm{QW}$ \\
\hline Q3 & 08169500 & $\begin{array}{l}\text { Guadalupe River at } \\
\text { New Braunfels, } \\
\text { Tex. }\end{array}$ & $\begin{array}{l}\text { Guadalupe } \\
\text { at New } \\
\text { Braunfels }\end{array}$ & $29^{\circ} 41^{\prime} 53^{\prime \prime}$ & $98^{\circ} 06^{\prime} 24^{\prime \prime}$ & 572.9 & $\mathrm{~N} / \mathrm{A}$ & N/A & $\mathrm{N} / \mathrm{A}$ & $\mathrm{N} / \mathrm{A}$ & QW \\
\hline Q4 & 08169932 & $\begin{array}{l}\text { Sink Creek } \\
\text { near San } \\
\text { Marcos, Tex. }\end{array}$ & Sink Creek & $29^{\circ} 55^{\prime} 45.57^{\prime \prime}$ & $97^{\circ} 59^{\prime} 39.33^{\prime \prime}$ & 742 & $\mathrm{~N} / \mathrm{A}$ & N/A & $\mathrm{N} / \mathrm{A}$ & $\mathrm{N} / \mathrm{A}$ & $\mathrm{Q}, \mathrm{QW}$ \\
\hline Q5 & 08169958 & $\begin{array}{c}\text { Purgatory Creek at } \\
\text { Mountain High } \\
\text { Drive near San } \\
\text { Marcos, Tex. }\end{array}$ & $\begin{array}{l}\text { Purgatory } \\
\text { Creek }\end{array}$ & $29^{\circ} 52^{\prime} 21.12^{\prime \prime}$ & $98^{\circ} 00^{\prime} 14.1^{\prime \prime}$ & 690 & $\mathrm{~N} / \mathrm{A}$ & N/A & $\mathrm{N} / \mathrm{A}$ & $\mathrm{N} / \mathrm{A}$ & G, QW \\
\hline Q6 & 08171000 & $\begin{array}{l}\text { Blanco River at } \\
\text { Wimberley, Tex. }\end{array}$ & $\begin{array}{l}\text { Blanco at } \\
\text { Wimberley }\end{array}$ & $29^{\circ} 59^{\prime} 40^{\prime \prime}$ & $98^{\circ} 05^{\prime} 20^{\prime \prime}$ & 797.6 & $\mathrm{~N} / \mathrm{A}$ & N/A & $\mathrm{N} / \mathrm{A}$ & $\mathrm{N} / \mathrm{A}$ & $\mathrm{Q}, \mathrm{QW}$ \\
\hline Q7 & 08171290 & $\begin{array}{l}\text { Blanco River at } \\
\text { Halifax Ranch } \\
\text { near Kyle, Tex. }\end{array}$ & $\begin{array}{r}\text { Blanco at } \\
\text { Halifax }\end{array}$ & $30^{\circ} 00^{\prime} 20^{\prime \prime}$ & $97^{\circ} 57^{\prime} 09^{\prime \prime}$ & 675 & N/A & N/A & N/A & N/A & M, Q, QW \\
\hline Q8 & 08171300 & $\begin{array}{l}\text { Blanco River near } \\
\text { Kyle, Tex. }\end{array}$ & $\begin{array}{l}\text { Blanco near } \\
\text { Kyle }\end{array}$ & $29^{\circ} 58^{\prime} 46^{\prime \prime}$ & $97^{\circ} 54^{\prime} 36^{\prime \prime}$ & 620.5 & $\mathrm{~N} / \mathrm{A}$ & N/A & $\mathrm{N} / \mathrm{A}$ & $\mathrm{N} / \mathrm{A}$ & $\mathrm{Q}, \mathrm{QW}$ \\
\hline Q9 & 08184300 & $\begin{array}{l}\text { Cibolo Creek at } \\
\text { Farm Road } \\
1863 \text { below } \\
\text { Bulverde, Tex. }\end{array}$ & $\begin{array}{c}\text { Cibolo at } \\
1863\end{array}$ & $29^{\circ} 43^{\prime} 57.6^{\prime \prime}$ & $98^{\circ} 21^{\prime} 22.98^{\prime \prime}$ & 941 & $\mathrm{~N} / \mathrm{A}$ & $\mathrm{N} / \mathrm{A}$ & N/A & $\mathrm{N} / \mathrm{A}$ & QW \\
\hline
\end{tabular}


Table 1. Water-quality sampling and data-collection sites for hydrologic and geochemical characterization of San Marcos Springs, south-central Texas (November 2008-December 2010).-Continued

[NAD 83, North American Datum of 1983; NAVD 88, North American Vertical Datum of 1988; dd, degrees; mm, minutes; ss, seconds; --, not available; N/A, not applicable; X, open hole; W, walled; S, screened; QW, water-quality samples (routine and [or] storm); WL, continuous groundwater altitude; $\mathrm{M}$, continuous water-quality monitor; G, continuous gage height; Q, continuous gage height and continuous discharge; TSU, Texas State University; do, ditto; USGS, U.S. Geological Survey]

\begin{tabular}{|c|c|c|c|c|c|c|c|c|c|c|c|}
\hline $\begin{array}{c}\text { Map } \\
\text { identifier } \\
\text { (fig. 1) }\end{array}$ & $\begin{array}{l}\text { U.S. Geological } \\
\text { Survey station } \\
\text { number }\end{array}$ & $\begin{array}{l}\text { U.S. Geological } \\
\text { Survey station } \\
\text { name (surface- } \\
\text { water sites) or } \\
\text { State well number } \\
\text { (groundwater } \\
\text { wells and springs) }\end{array}$ & Short name & $\begin{array}{l}\text { Latitude, in } \\
\text { dd mm ss } \\
\text { (NAD 83) }\end{array}$ & $\begin{array}{l}\text { Longitude, } \\
\text { in dd mm ss } \\
\text { (NAD 83) }\end{array}$ & $\begin{array}{c}\text { Altitude of } \\
\text { land surface } \\
\text { (NAVD 88) } \\
\text { (feet) }\end{array}$ & $\begin{array}{l}\text { Contributing } \\
\text { aquifer(s) }\end{array}$ & $\begin{array}{l}\text { Well } \\
\text { depth } \\
\text { (feet) }\end{array}$ & $\begin{array}{c}\text { Well open } \\
\text { interval } \\
\text { (feet) }\end{array}$ & $\begin{array}{c}\text { Well } \\
\text { completion } \\
\text { type }\end{array}$ & $\begin{array}{l}\text { Data } \\
\text { type(s) }\end{array}$ \\
\hline \multicolumn{12}{|c|}{ Surface-water sites-Continued } \\
\hline Q10 & 08167800 & $\begin{array}{l}\text { Guadalupe River } \\
\text { at Sattler, Tex. }\end{array}$ & $\begin{array}{l}\text { Guadalupe at } \\
\text { Sattler }\end{array}$ & $29^{\circ} 51 ' 33^{\prime \prime}$ & $98^{\circ} 10^{\prime} 48^{\prime \prime}$ & 742 & N/A & N/A & N/A & N/A & Q \\
\hline Q11 & 08168797 & $\begin{array}{l}\text { Dry Comal Creek } \\
\text { at Loop } 337 \\
\text { near New } \\
\text { Braunfels, Tex. }\end{array}$ & Dry Comal & $29^{\circ} 41^{\prime} 16.8^{\prime \prime}$ & $98^{\circ} 09^{\prime} 17.4^{\prime \prime}$ & 610 & N/A & N/A & N/A & N/A & Q \\
\hline Q12 & 08183890 & $\begin{array}{l}\text { Cibolo Creek at } \\
\text { Cibolo Nature } \\
\text { Center near } \\
\text { Boerne, Tex. }\end{array}$ & $\begin{array}{l}\text { Cibolo Nature } \\
\text { Center }\end{array}$ & $29^{\circ} 46^{\prime} 52.07^{\prime \prime}$ & $98^{\circ} 42^{\prime} 46.19^{\prime \prime}$ & 1358 & $\mathrm{~N} / \mathrm{A}$ & N/A & N/A & N/A & Q \\
\hline Q13 & 08185000 & $\begin{array}{c}\text { Cibolo Creek at } \\
\text { Selma, Tex. }\end{array}$ & $\begin{array}{c}\text { Cibolo at } \\
\text { Selma }\end{array}$ & $29^{\circ} 35^{\prime} 39^{\prime \prime}$ & $98^{\circ} 18^{\prime} 40^{\prime \prime}$ & 728 & N/A & N/A & N/A & N/A & Q \\
\hline \multicolumn{12}{|c|}{ Groundwater wells } \\
\hline W1 & 294604098060701 & DX-68-16-707 & 4D well & -- & -- & 802 & Edwards & 400 & $195-400$ & $\mathrm{X}$ & QW \\
\hline W2 & 294739098075301 & DX-68-15-605 & Bonem well & $29^{\circ} 47^{\prime} 39^{\prime \prime}$ & $98^{\circ} 07^{\prime} 53^{\prime \prime}$ & 860 & Edwards & 375 & $220-375$ & W & QW \\
\hline W3 & 295019097592701 & LR-67-09-113 & $\begin{array}{l}\text { Fish Hatchery } \\
1 \text { well }\end{array}$ & $29^{\circ} 50^{\prime} 19.46^{\prime \prime}$ & $97^{\circ} 59^{\prime} 26.65^{\prime \prime}$ & 714 & Edwards & 280 & $216-280$ & $X$ & QW \\
\hline W4 & 295033098041201 & DX-68-16-201 & Mendez well & $29^{\circ} 50^{\prime} 33^{\prime \prime}$ & $98^{\circ} 04^{\prime} 12^{\prime \prime}$ & 991 & Trinity & 640 & $580-640$ & S & QW \\
\hline W5 & 295052098070801 & DX-68-16-101 & $\begin{array}{l}\text { Sac-N-Pac } \\
\text { well }\end{array}$ & $29^{\circ} 50^{\prime} 52^{\prime \prime}$ & $98^{\circ} 07^{\prime} 08^{\prime \prime}$ & 1,020 & Trinity & 408 & $256-408$ & $\mathrm{X}$ & QW \\
\hline W6 & 295314097565701 & LR-67-01-826 & $\begin{array}{l}\text { TSU-West } \\
\text { Campus } \\
\text { well }\end{array}$ & $29^{\circ} 53^{\prime} 14.04^{\prime \prime}$ & $97^{\circ} 56^{\prime} 57.47^{\prime \prime}$ & 751 & Edwards & 210 & $103-210$ & $\mathrm{X}$ & $\begin{array}{c}\text { M, QW, } \\
\text { WL }\end{array}$ \\
\hline W7 & 295323097561101 & LR-67-01-828 & $\begin{array}{l}\text { TSU-Artesian } \\
\text { well }\end{array}$ & $29^{\circ} 53^{\prime} 22.5^{\prime \prime}$ & $97^{\circ} 56^{\prime} 11.2^{\prime \prime}$ & 577 & Edwards & 600 & 0-199 & $\mathrm{X}$ & QW \\
\hline W8 & 295325097564301 & LR-67-01-827 & $\begin{array}{l}\text { TSU-Jackson } \\
1 \text { well }\end{array}$ & $29^{\circ} 53^{\prime} 25^{\prime \prime}$ & $97^{\circ} 56^{\prime} 42.9^{\prime \prime}$ & 740 & Edwards & 191 & $135-191$ & $\mathrm{X}$ & QW \\
\hline W9 & 295345098001001 & LR-68-08-902 & SMBA 1 well & $29^{\circ} 53^{\prime} 45^{\prime \prime}$ & $98^{\circ} 00^{\prime} 10^{\prime \prime}$ & 770 & Edwards & 335 & $200-335$ & $\mathrm{X}$ & QW \\
\hline
\end{tabular}


Table 1. Water-quality sampling and data-collection sites for hydrologic and geochemical characterization of San Marcos Springs, south-central Texas

(November 2008-December 2010).-Continued

[NAD 83, North American Datum of 1983; NAVD 88, North American Vertical Datum of 1988; dd, degrees; mm, minutes; ss, seconds; --, not available; N/A, not applicable; X, open hole; W, walled; S, screened; QW, water-quality samples (routine and [or] storm); WL, continuous groundwater altitude; M, continuous water-quality monitor; G, continuous gage height; Q, continuous gage height and continuous discharge; TSU, Texas State University; do, ditto; USGS, U.S. Geological Survey]

\begin{tabular}{|c|c|c|c|c|c|c|c|c|c|c|c|}
\hline $\begin{array}{l}\text { Map } \\
\text { identifier } \\
\text { (fig. 1) }\end{array}$ & $\begin{array}{c}\text { U.S. Geological } \\
\text { Survey station } \\
\text { number }\end{array}$ & $\begin{array}{l}\text { U.S. Geological } \\
\text { Survey station } \\
\text { name (surface- } \\
\text { water sites) or } \\
\text { State well number } \\
\text { (groundwater } \\
\text { wells and springs) }\end{array}$ & Short name & $\begin{array}{l}\text { Latitude, in } \\
\text { dd mm ss } \\
\text { (NAD 83) }\end{array}$ & $\begin{array}{l}\text { Longitude, } \\
\text { in dd mm ss } \\
\text { (NAD 83) }\end{array}$ & $\begin{array}{l}\text { Altitude of } \\
\text { land surface } \\
\text { (NAVD 88) } \\
\text { (feet) }\end{array}$ & $\begin{array}{l}\text { Contributing } \\
\text { aquifer(s) }\end{array}$ & $\begin{array}{l}\text { Well } \\
\text { depth } \\
\text { (feet) }\end{array}$ & $\begin{array}{c}\text { Well open } \\
\text { interval } \\
\text { (feet) }\end{array}$ & $\begin{array}{c}\text { Well } \\
\text { completion } \\
\text { type }\end{array}$ & $\begin{array}{c}\text { Data } \\
\text { type(s) }\end{array}$ \\
\hline \multicolumn{12}{|c|}{ Groundwater wells - Continued } \\
\hline W10 & 295352098071201 & DX-68-08-701 & Riedel well & $29^{\circ} 53^{\prime} 52^{\prime \prime}$ & $98^{\circ} 07^{\prime} 12^{\prime \prime}$ & 1,150 & Edwards & 240 & $239-240$ & $\mathrm{~S}$ & QW \\
\hline W11 & 295406097551201 & LR-67-01-818 & Horton well & $29^{\circ} 54^{\prime} 06^{\prime \prime}$ & $97^{\circ} 55^{\prime} 12^{\prime \prime}$ & 610 & Edwards & 80 & $10-80$ & $\mathrm{X}$ & QW \\
\hline W12 & 295443097554201 & LR-67-01-809 & Tipps well & $29^{\circ} 54^{\prime} 43^{\prime \prime}$ & $97^{\circ} 55^{\prime} 42^{\prime \prime}$ & 601.3 & Edwards & 32.5 & $0-32.5$ & $\mathrm{~W}$ & $\mathrm{M}, \mathrm{WL}$ \\
\hline W13 & 295515097581801 & LR-67-01-403 & Solar well & $29^{\circ} 55^{\prime} 15.1^{\prime \prime}$ & $97^{\circ} 58^{\prime} 17.9^{\prime \prime}$ & 688 & Edwards & -- & -- & $\mathrm{X}$ & QW \\
\hline W14 & 295524098114401 & DX-68-07-505 & $\begin{array}{l}\text { Eagle Peak } \\
\text { well }\end{array}$ & -- & -- & 1,177 & Trinity & 732 & $200-732$ & $X$ & QW \\
\hline W15 & 295530097563201 & LR-67-01-503 & Neff well & $29^{\circ} 55^{\prime} 30^{\prime \prime}$ & $97^{\circ} 56^{\prime} 32^{\prime \prime}$ & 733 & Edwards & 280 & $180-240$ & $\mathrm{~S}$ & QW \\
\hline do & do & do & do & do & do & do & do & do & $240-280$ & $\mathrm{X}$ & -- \\
\hline W16 & 295538098042101 & LR-68-08-502 & Burns well & $29^{\circ} 55^{\prime} 38^{\prime \prime}$ & $98^{\circ} 04^{\prime} 21^{\prime \prime}$ & 1,041 & Trinity & 700 & $400-700$ & $\mathrm{~S}$ & QW \\
\hline W17 & 295709098000301 & LR-68-08-602 & Laguna well & $29^{\circ} 57^{\prime} 08.5^{\prime \prime}$ & $98^{\circ} 00^{\prime} 03^{\prime \prime}$ & 906 & Edwards & 600 & -- & $\mathrm{X}$ & QW \\
\hline W18 & 295806097540901 & LR-67-01-312 & Aqua well & -- & -- & 683 & Edwards & 520 & $300-520$ & $\mathrm{X}$ & QW \\
\hline W19 & 295915097525501 & LR-67-01-309 & $\begin{array}{l}\text { City of Kyle } 2 \\
\text { well }\end{array}$ & -- & -- & 753 & Edwards & 658 & $328-658$ & $\mathrm{X}$ & QW \\
\hline W20 & 300041097563901 & LR-58-57-808 & Halifax well & $30^{\circ} 00^{\prime} 41^{\prime \prime}$ & $97^{\circ} 56^{\prime} 39^{\prime \prime}$ & 740 & Edwards & 220 & $161-220$ & $\mathrm{~W}$ & QW \\
\hline W21 & 300331097551601 & LR-58-57-512 & $\begin{array}{l}\text { Ruby Ranch } \\
\text { well }\end{array}$ & -- & -- & 830 & $\begin{array}{c}\text { Edwards and } \\
\text { Trinity }\end{array}$ & 405 & $182-405$ & $X$ & QW \\
\hline W22 & 300453097503301 & LR-58-58-403 & Buda well & -- & -- & 710 & Edwards & 390 & $168-390$ & $X$ & QW \\
\hline \multicolumn{12}{|c|}{ Springs } \\
\hline $\begin{array}{l}\text { Hueco } \\
\text { Springs }\end{array}$ & 08168000 & $\begin{array}{l}\text { Hueco Springs } \\
\text { near New } \\
\text { Braunfels, Tex }\end{array}$ & $\begin{array}{l}\text { Hueco } \\
\text { Springs }\end{array}$ & $29^{\circ} 45^{\prime} 34^{\prime \prime}$ & $98^{\circ} 08^{\prime} 24^{\prime \prime}$ & 644.9 & Edwards & N/A & N/A & N/A & Q \\
\hline $\begin{array}{l}\text { Comal } \\
\text { Springs }\end{array}$ & 08168710 & $\begin{array}{l}\text { Comal Springs at } \\
\text { New Braunfels, } \\
\text { Tex. }\end{array}$ & $\begin{array}{l}\text { Comal } \\
\text { Springs }\end{array}$ & $29^{\circ} 42^{\prime} 22^{\prime \prime}$ & $98^{\circ} 07^{\prime} 21^{\prime \prime}$ & 582.9 & Edwards & N/A & N/A & N/A & Q \\
\hline $\begin{array}{l}\text { San } \\
\text { Marcos } \\
\text { Springs }\end{array}$ & 08170000 & $\begin{array}{l}\text { San Marcos } \\
\text { Springs at San } \\
\text { Marcos, Tex. }\end{array}$ & $\begin{array}{c}\text { San Marcos } \\
\text { Springs }\end{array}$ & $29^{\circ} 53^{\prime} 21^{\prime \prime}$ & $97^{\circ} 56^{\prime} 02^{\prime \prime}$ & 557.8 & Edwards & N/A & N/A & N/A & Q \\
\hline
\end{tabular}


Table 1. Water-quality sampling and data-collection sites for hydrologic and geochemical characterization of San Marcos Springs, south-central Texas (November 2008-December 2010).-Continued

[NAD 83, North American Datum of 1983; NAVD 88, North American Vertical Datum of 1988; dd, degrees; mm, minutes; ss, seconds; --, not available; N/A, not applicable; X, open hole; W, walled; S, screened; QW, water-quality samples (routine and [or] storm); WL, continuous groundwater altitude; M, continuous water-quality monitor; G, continuous gage height; Q, continuous gage height and continuous discharge; TSU, Texas State University; do, ditto; USGS, U.S. Geological Survey]

\begin{tabular}{|c|c|c|c|c|c|c|c|c|c|c|c|}
\hline $\begin{array}{l}\text { Map } \\
\text { identifier } \\
\text { (fig. 1) }\end{array}$ & $\begin{array}{l}\text { U.S. Geological } \\
\text { Survey station } \\
\text { number }\end{array}$ & $\begin{array}{l}\text { U.S. Geological } \\
\text { Survey station } \\
\text { name (surface- } \\
\text { water sites) or } \\
\text { State well number } \\
\text { (groundwater } \\
\text { wells and springs) }\end{array}$ & Short name & $\begin{array}{l}\text { Latitude, in } \\
\text { dd mm ss } \\
\text { (NAD 83) }\end{array}$ & $\begin{array}{l}\text { Longitude, } \\
\text { in dd mm ss } \\
\text { (NAD 83) }\end{array}$ & $\begin{array}{l}\text { Altitude of } \\
\text { land surface } \\
\text { (NAVD 88) } \\
\text { (feet) }\end{array}$ & $\begin{array}{l}\text { Contributing } \\
\text { aquifer(s) }\end{array}$ & $\begin{array}{l}\text { Well } \\
\text { depth } \\
\text { (feet) }\end{array}$ & $\begin{array}{c}\text { Well open } \\
\text { interval } \\
\text { (feet) }\end{array}$ & $\begin{array}{c}\text { Well } \\
\text { completion } \\
\text { type }\end{array}$ & $\begin{array}{c}\text { Data } \\
\text { type(s) }\end{array}$ \\
\hline \multicolumn{12}{|c|}{ Springs-Continued } \\
\hline $\mathrm{S} 1$ & 294255098080501 & DX-68-23-324 & $\begin{array}{l}\text { Comal } \\
\text { Spring } 3\end{array}$ & $29^{\circ} 42^{\prime} 55.38^{\prime \prime}$ & $98^{\circ} 08^{\prime} 04.92^{\prime \prime}$ & 625 & Edwards & N/A & N/A & N/A & QW \\
\hline $\mathrm{S} 2$ & 294300098080001 & DX-68-23-301 & $\begin{array}{l}\text { Comal } \\
\text { Spring } 1\end{array}$ & $29^{\circ} 42^{\prime} 46^{\prime \prime}$ & $98^{\circ} 08^{\prime} 15^{\prime \prime}$ & 623.43 & Edwards & N/A & N/A & N/A & QW \\
\hline S3 & 294314098074101 & DX-68-23-326 & $\begin{array}{l}\text { Comal } \\
\text { Spring } 5\end{array}$ & $29^{\circ} 43^{\prime} 14.22^{\prime \prime}$ & $98^{\circ} 07^{\prime} 41.46^{\prime \prime}$ & 626 & Edwards & N/A & N/A & N/A & QW \\
\hline S4 & 294533098082301 & DX-68-15-901 & $\begin{array}{l}\text { Hueco } \\
\quad \text { Spring A }\end{array}$ & $29^{\circ} 45^{\prime} 34^{\prime \prime}$ & $98^{\circ} 08^{\prime} 24^{\prime \prime}$ & 652.53 & Edwards & N/A & N/A & N/A & QW \\
\hline S5 & 295322097561000 & LR-67-01-819 & $\begin{array}{l}\text { Deep } \\
\text { Spring (San } \\
\text { Marcos) }\end{array}$ & $29^{\circ} 53^{\prime} 33^{\prime \prime}$ & $97^{\circ} 55^{\prime} 54^{\prime \prime}$ & 600 & Edwards & N/A & N/A & N/A & M, QW \\
\hline S6 & 295322097561002 & LR-67-01-820 & $\begin{array}{l}\text { Weissmuller } \\
\text { Spring (San } \\
\text { Marcos) }\end{array}$ & $29^{\circ} 53^{\prime} 36^{\prime \prime}$ & $97^{\circ} 55^{\prime} 48^{\prime \prime}$ & 600 & Edwards & N/A & N/A & N/A & $\mathrm{M}, \mathrm{QW}$ \\
\hline S7 & 295336097555201 & LR-67-01-825 & $\begin{array}{l}\text { Diversion } \\
\text { Spring (San } \\
\text { Marcos) }\end{array}$ & $29^{\circ} 53^{\prime} 35.64^{\prime \prime}$ & $97^{\circ} 55^{\prime} 51.9^{\prime \prime}$ & 580 & Edwards & N/A & N/A & N/A & M, QW \\
\hline \multicolumn{12}{|c|}{ Rain sample collection site } \\
\hline P1 & 293146982941 & $\begin{array}{c}\text { San Antonio Sub- } \\
\text { district at San } \\
\text { Antonio, Tex. }\end{array}$ & $\begin{array}{c}\text { USGS San } \\
\text { Antonio }\end{array}$ & $29^{\circ} 31^{\prime} 47^{\prime \prime}$ & $98^{\circ} 29^{\prime} 42^{\prime \prime}$ & 970 & N/A & N/A & N/A & N/A & QW \\
\hline
\end{tabular}


Table 2. Number of samples analyzed for water quality for characterization of San Marcos Springs, south-central Texas (November 2008-December 2010).

[Bold indicates sites selected for routine sampling throughout the study; TSU, Texas State University]

\begin{tabular}{|c|c|c|c|c|c|}
\hline \multirow{2}{*}{$\begin{array}{l}\text { Map identifier } \\
\text { (fig. 1) }\end{array}$} & \multirow{2}{*}{$\begin{array}{l}\text { U.S. Geological Survey } \\
\text { station number }\end{array}$} & \multirow{2}{*}{ Short name ${ }^{1}$} & \multicolumn{2}{|c|}{$\begin{array}{c}\text { Number of } \\
\text { routine samples }\end{array}$} & \multirow{2}{*}{$\begin{array}{c}\text { Number of } \\
\text { storm samples }\end{array}$} \\
\hline & & & $\begin{array}{c}\text { Dry } \\
\text { period }\end{array}$ & $\begin{array}{c}\text { Wet } \\
\text { period }\end{array}$ & \\
\hline \multicolumn{6}{|c|}{ Surface-water sites } \\
\hline Q1 & 08167990 & Guadalupe at River Road & 7 & 9 & 2 \\
\hline Q2 & 08168500 & Guadalupe above Comal & 1 & 0 & 0 \\
\hline Q4 & 08169932 & Sink Creek & 0 & 0 & 2 \\
\hline Q5 & 08169958 & Purgatory Creek & 0 & 0 & 1 \\
\hline Q6 & 08171000 & Blanco at Wimberley & 1 & 0 & 0 \\
\hline Q7 & 08171290 & Blanco at Halifax & 7 & 9 & 4 \\
\hline W1 & 294604098060701 & 4D well (DX-68-16-707) & 6 & 9 & 0 \\
\hline W2 & 294739098075301 & Bonem well (DX-68-15-605) & 1 & 0 & 0 \\
\hline W3 & 295019097592701 & Fish Hatchery 1 well (LR-67-09-113) & 3 & 1 & 0 \\
\hline W4 & 295033098041201 & Mendez well (DX-68-16-201) & 7 & 10 & 0 \\
\hline W5 & 295052098070801 & Sac-N-Pac well (DX-68-16-101) & 7 & 5 & 0 \\
\hline W6 & 295314097565701 & TSU-West Campus well (LR-67-01-826) & 3 & 9 & 0 \\
\hline W7 & 295323097561101 & TSU-Artesian well (LR-67-01-828) & 1 & 0 & 0 \\
\hline W8 & 295325097564301 & TSU-Jackson 1 well (LR-67-01-827) & 1 & 0 & 0 \\
\hline W9 & 295345098001001 & SMBA 1 well (LR-68-08-902) & 1 & 0 & 0 \\
\hline W17 & 295709098000301 & Laguna well (LR-68-08-602) & 1 & 0 & 0 \\
\hline W18 & 295806097540901 & Aqua well (LR-67-01-312) & 7 & 5 & 0 \\
\hline W19 & 295915097525501 & City of Kyle 2 well (LR-67-01-309) & 1 & 0 & 0 \\
\hline W20 & 300041097563901 & Halifax well (LR-58-57-808) & 1 & 0 & 0 \\
\hline W21 & 300331097551601 & Ruby Ranch well (LR-58-57-512) & 6 & 3 & 0 \\
\hline W22 & 300453097503301 & Buda well (LR-58-58-403 ) & 2 & 0 & 0 \\
\hline \multicolumn{6}{|c|}{ Springs } \\
\hline S1 & 294255098080501 & Comal Spring 3 (DX-68-23-324) & 1 & 0 & 0 \\
\hline $\mathbf{S 2}$ & 294300098080001 & Comal Spring 1 (DX-68-23-301) & 7 & ${ }^{2} 10$ & 8 \\
\hline S3 & 294314098074101 & Comal Spring 5 (DX-68-23-326) & 1 & 0 & 0 \\
\hline S4 & 294533098082301 & Hueco Spring A (DX-68-15-901) & 7 & ${ }^{2} 10$ & 8 \\
\hline S5 & 295322097561000 & Deep Spring (San Marcos) (LR-67-01-819) & 7 & 9 & 17 \\
\hline S6 & 295322097561002 & Weissmuller Spring (San Marcos) (LR-67-01-820) & 0 & 5 & 6 \\
\hline S7 & 295336097555201 & Diversion Spring (San Marcos) (LR-67-01-825) & 7 & 9 & 17 \\
\hline
\end{tabular}

${ }^{1}$ See table 1 for complete U.S. Geological Survey station names and numbers.

${ }^{2}$ One sample analyzed only for stable isotopes. 


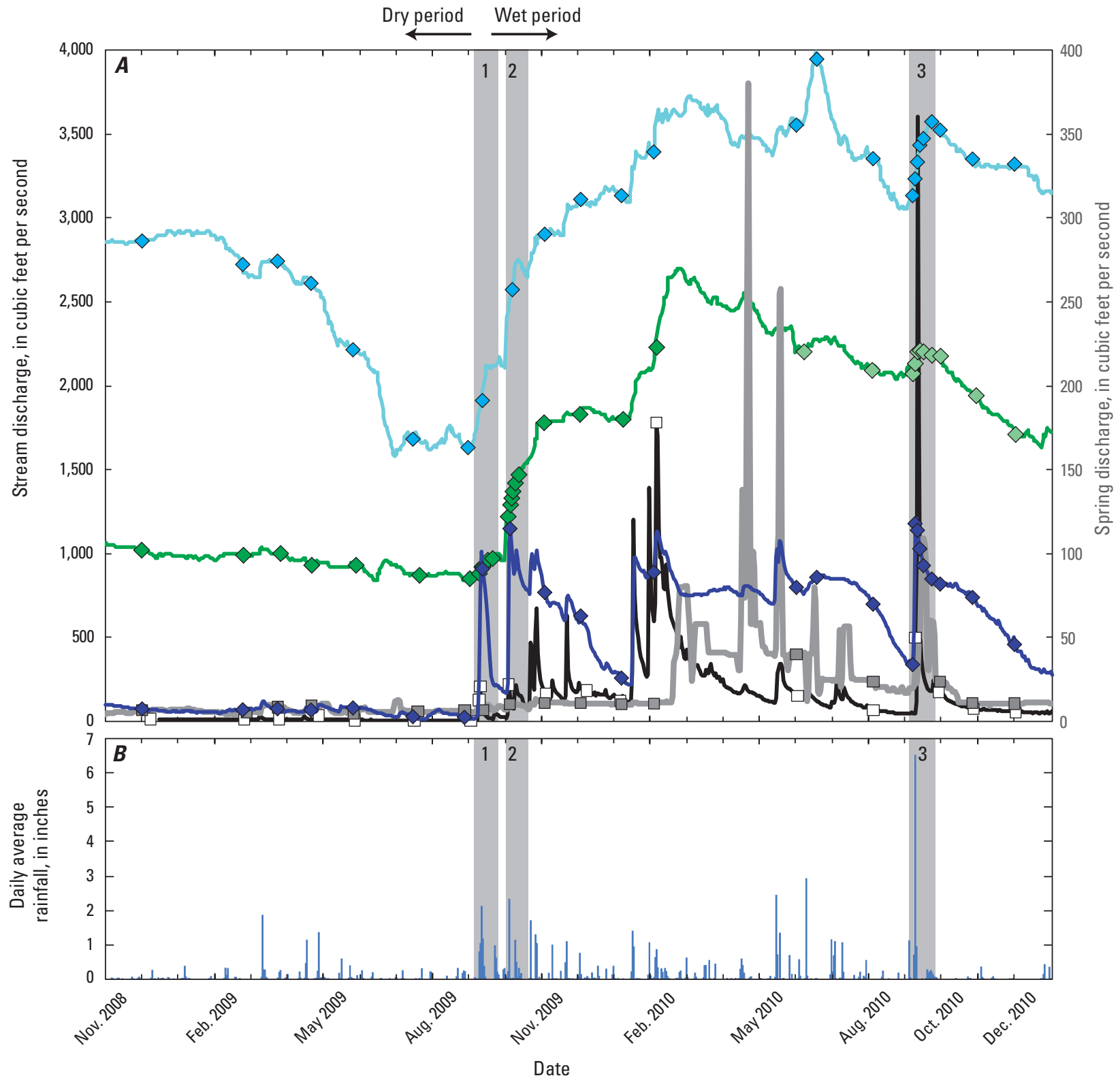

\section{EXPLANATION}

3 Time period of major storm response sampling and and storm identifier

Discharge (daily mean) at surface-water site, by stream

- Blanco River-Halifax Ranch near Kyle, Texas (USGS station 08171290)

Guadalupe River-Sattler, Tex. (USGS station 08167800)
Discharge (daily mean) at springComposite of individual orifices (table 1)

- San Marcos Springs
Comal Springs

- Hueco Springs

Sample, by stream

$\square \quad$ Blanco River-Sample collection at Halifax Ranch near Kyle, Tex. (USGS station 08171290)

$\square \quad$ Guadalupe River-Sample collection at River Road near Sattler, Tex. (USGS station 08167990)

\section{Sample, by spring}

San Marcos Springs-Sample collection at Deep and Diversion Springs (USGS stations 295322097561000 and 295336097555201 , respectively)

$\diamond$ San Marcos Springs-Sample collection at Deep and Diversion Springs and at Weissmuller Spring (USGS station 295322097561002)

$\diamond$ Comal Springs-Sample collection at Comal Spring 1 (USGS station 294300098080001)

$\checkmark$ Hueco Springs-Sample collection at Hueco Spring A (USGS station 294533098082301)

USGS, U.S. Geological Survey

Figure 5. Time series (November 2008-December 2010) of $A$, stream discharge and spring discharge for multiple sites sampled for the characterization of San Marcos Springs, south-central Texas, and timing of collection of samples; and $B$, Rainfall hyetograph in the vicinity of San Marcos Springs, Hays County, south-central Texas (mean for National Weather Service Cooperative Stations 411429, 412585, 416276, 417983, 418544, and 419815, National Oceanic and Atmospheric Administration, 2011). 
Stream sites selected for routine sampling were the Blanco River at Halifax Ranch near Kyle, Tex. (USGS station number 08171290; hereinafter, Blanco at Halifax) and the Guadalupe River at River Road near Sattler, Tex. (USGS station 08167990; hereinafter, Guadalupe at River Road). Wells selected for routine sampling (detailed in table 2) included wells completed in the Edwards aquifer and in the underlying Trinity aquifer. Spring orifices DX-68-23-301 (Comal Spring 1) in the Comal Springs complex, and DX-68-15-901 (Hueco Spring A) were selected for routine sampling (fig. 1). Comal Spring 1 is the southernmost large spring that emerges from the Comal Springs Fault at the Comal Springs complex. Hueco Spring A is the lower elevation spring of the two orifices at Hueco Springs. Samples collected from Comal Spring 1 and Hueco Spring A are considered for the purposes of this report to be representative of discharge from Comal and Hueco Springs. At San Marcos Springs (figs. 1 and 4), Deep Spring (LR-67-01-819, submerged at a depth of about $28 \mathrm{ft}$ in the southwest part of Spring Lake) was selected to be representative of springs discharging from the southern part of Spring Lake. Diversion Spring (LR-67-01-825, submerged at a depth of about $20 \mathrm{ft}$ in the northeast part of Spring Lake) and Weissmuller Spring (LR-67-01-820, submerged at a depth of about $24 \mathrm{ft}$ in the northeast part of Spring Lake) were selected to be representative of springs discharging from the northern part of Spring Lake. In contrast with the 2008-10 sampling period for the other springs, the sampling period for Weissmuller Spring was from June through December 2010.

To characterize changes in water quality in response to storm events, samples were collected in response to three major storms (storms 1-3) from nearby streams that potentially contribute recharge to San Marcos Springs, from Comal Spring 1, from Hueco Spring A, and from the three spring orifices at San Marcos Springs (Deep, Diversion, and Weissmuller Springs) (table 2; fig. 5); no groundwater samples were collected in response to storms. Storm samples from the streams were collected depending on flow conditions. At the springs, in response to storms 1 and 2, single samples were collected at Comal Spring 1 and Hueco Spring A; at San Marcos Springs, five (storm 1) or six (storm 2) samples were collected at closely spaced intervals (hours to days) from Deep and Diversion Springs. In response to storm 3, six samples were collected at closely spaced intervals (hours to days) from Comal Spring 1, Hueco Spring A, Deep Spring, Diversion Spring, and Weissmuller Spring. Of these storm 3 samples for each of these sites, one sample considered as a storm sample in Crow (2012) is considered as a routine sample in this report. All samples were analyzed for the same constituents as routine samples, as described by Crow (2012).
In addition to routine and storm sample collection, discharge and selected physicochemical properties were measured at 15-minute intervals ("continuously") at the Blanco at Halifax stream site from February 2009 through December 2010 and at the three San Marcos Springs orifices (Deep Spring, from February 2009 through December 2010; Diversion Spring, from April 2009 through December 2010; and Weissmuller Spring, from June 2010 through December 2010). Water temperature, specific conductance, $\mathrm{pH}$, turbidity, and dissolved oxygen concentration were recorded at Blanco at Halifax; dissolved oxygen was not recorded at the springs. Water-table altitude, water temperature, and specific conductance were measured at hourly intervals in two wells near San Marcos Springs: (1) LR-67-01-809 (hereinafter, Tipps well; fig. 1, map identifier W12) from November 2008May 2010 and (2) LR-67-01-826 (hereinafter, TSU-West Campus well; fig. 1, map identifier W6) from January 2009-December 2010. Rain samples were collected at the USGS South Texas Program office in San Antonio (USGS station 293146982941; fig. 1, map identifier P1) periodically (March 2009-September 2010) and in response to storms 1-3 and were analyzed for stable isotope ratios of hydrogen (delta deuterium, $\delta \mathrm{D}$ ) and oxygen (delta oxygen-18, $\delta^{18} \mathrm{O}$ ). Continuous discharge data for the San Marcos Springs complex, the Comal Springs complex, the Hueco Springs complex, and other stream sites from ongoing data-collection efforts by the USGS (table 1) also were used in data analysis. These continuous data, available from the USGS National Water Information System (NWIS; U.S. Geological Survey, 2011), are used as interpretative aids throughout this report. Daily mean values for all continuous discharge, water-table altitudes, and physicochemical properties are presented and discussed throughout this report. Hydrologic and geochemical variability at San Marcos Springs was compared with that at Comal Springs and Hueco Springs.

\section{Sample Collection, Analytical Methods, and Quality Control}

All associated data collected during this study—as well as descriptions of sample collection, sample processing, analytical methods, and quality-control assessment - are described in detail in a companion USGS Data Series report (Crow, 2012). All nitrogen (N) species are reported and discussed as N. Recorded turbidity values below the method reporting level of 0.3 formazin nephelometric units (FNU) are considered nondetections ( $<0.3 \mathrm{FNU}$ ), although measured values less than $0.3 \mathrm{FNU}$ are shown on some figures in this report for completeness. 


\section{Rainfall Estimation}

Daily rainfall data were compiled from the National Climatic Data Center (NCDC) for six National Weather Service (NWS) meteorological stations within the study area: Canyon Dam, Dripping Springs 6 E, New Braunfels, San Marcos, Spring Branch 2se, and Wimberley $1 \mathrm{NW}$ (Cooperative Stations 411429, 412585, 416276, 417983, 418544, and 419815, respectively) (National Oceanic and Atmospheric Administration, 2011). Daily rainfall data from these sites were averaged to obtain a composite rainfall record for the study.

\section{Streamflow Measurements and Recharge Estimation}

At USGS streamflow-gaging stations, streamflow (discharge) records are computed from the stage, or gage height, which is measured continuously. A stage-discharge relation is developed for each site by the USGS on the basis of streamflow measurements and the stage of the stream at the time of measurement (Kennedy, 1984), which is used to compute a record of streamflow (Kennedy, 1983). Continuous streamflow data are available from NWIS (U.S. Geological Survey, 2011).

Monthly recharge to the San Antonio segment of the Edwards aquifer has been estimated by the USGS for each of the contributing drainage basins since 1934 (Edwards Aquifer Authority, 2010) by using a water-balance approach based on streamflow measurements; the method, documented by Puente (1978), uses data collected from a network of USGS streamflow-gaging stations. For this study, streams near San Marcos Springs were evaluated as potential local recharge sources. Recharge estimates were computed daily for 2008-10 for the Blanco River, Cibolo Creek, and Dry Comal Creek (fig. 1) by using discharge from USGS streamflowgaging stations in each basin. Daily mean recharge estimates were disaggregated from the annual recharge estimates determined by the Puente (1978) method by multiplying the annual recharge value by the fraction of annual basin discharge occurring on that day (R.N. Slattery, U.S.

Geological Survey, written commun., 2011). During periods of relatively large amounts of runoff, estimated daily recharge values exceeded measured daily discharge at some sites. As a result, a 5-day average recharge estimate also was considered to adjust for the allocation of large amounts of recharge to days with large events.

For the Blanco River and Cibolo Creek, recharge estimates were based on discharge measured at paired USGS streamflow-gaging stations upstream and downstream from the Edwards aquifer recharge zone in each basin. For the Blanco River, the upstream station was either 08171000 (Blanco River at Wimberley, Tex.; hereinafter, Blanco at Wimberley; fig. 1, map identifier Q6) or Blanco at Halifax (fig. 1); the downstream station was 08171300 (Blanco River near Kyle, Tex.; hereinafter, Blanco near Kyle; fig. 1, map identifier Q8). For Cibolo Creek (fig. 1), the upstream station was 08183890 (Cibolo Creek at Cibolo Nature Center near Boerne, Tex.; hereinafter Cibolo Nature Center; fig. 1, map identifier Q12); the downstream station was 08185000 (Cibolo Creek at Selma, Tex.; hereinafter, Cibolo at Selma; fig. 1, map identifier Q13). For Dry Comal Creek (fig. 1), daily basin discharge was estimated from the discharge at station 08168797 (Dry Comal Creek at Loop 337 near New Braunfels, Tex., hereinafter, Dry Comal; fig. 1, map identifier Q11) and the upstream discharge estimated from the discharge occurring in the Guadalupe River Basin between station 08167800 (Guadalupe River at Sattler, Tex.; hereinafter, Guadalupe at Sattler; fig. 1, map identifier Q10) and station 08168500 (Guadalupe River above Comal River at New Braunfels, Tex.; hereinafter, Guadalupe above Comal; fig. 1, map identifier Q2) (R.N. Slattery, U.S. Geological Survey, written commun., 2011).

For the Blanco River, historical recharge estimates have been based on stream discharge at the upstream Blanco at Wimberley gage and the downstream Blanco near Kyle gage (hereinafter referred to as the "Wimberley-to-Kyle method"). For 2009-10, recharge for the Blanco River also was estimated by using a second method where discharge from the Blanco at Halifax gage was considered as the upstream gage instead of the Blanco at Wimberley gage. The Blanco at Wimberley gage used in the Wimberley-to-Kyle method is approximately $12 \mathrm{mi}$ upstream from the recharge zone. The Blanco at Halifax gage, installed for this study, is less than $1 \mathrm{mi}$ upstream from the recharge zone and provided data that might yield a more accurate assessment of potential recharge to the Edwards aquifer from the Blanco River. This second method of estimating recharge on this shorter section of the Blanco River for 2009-10 (hereinafter referred to as the "Halifax-to-Kyle method") required that the drainage areas in Puente's (1978) equations be modified to adjust the upstream drainage area and the intervening area between the upstream and downstream stations. Historical recharge estimates for the Edwards aquifer have not included estimates for the Guadalupe River because the Guadalupe River Basin likely does not contribute appreciable recharge to the aquifer (Puente, 1978). Nonetheless, for this study, a rudimentary gain-loss summary was estimated for the Guadalupe River between the Guadalupe at Sattler station and the Guadalupe above Comal station. Streamflow gain-loss was estimated 
from the measured streamflow value at the Guadalupe above Comal station less the measured values for streamflow at the Guadalupe at Sattler station and discharge at Hueco Springs. Gaining flow was interpreted to indicate that no aquifer recharge was occurring and correspondingly, losing flow was interpreted to represent aquifer recharge.

In addition to recharge from streamflow, recharge to the aquifer occurs through internal drainage sinkholes or as diffuse recharge through soils; while not well quantified, this type of recharge has been estimated to range from 20 to 40 percent of total aquifer recharge for the San Antonio segment of the Edwards aquifer (Klemt and others, 1979; Maclay and Land, 1988; Thorkildsen and McElhaney, 1992). Additional recharge likely occurs by leakage from the underlying Trinity aquifer (Sharp and Banner, 1997; Mace and others, 2000) and has been estimated to range from 2 to 9 percent of total annual aquifer recharge (Lowry, 1955; Woodruff and Abbott, 1986; LBG-Guyton Associates, 1995; Mace and others, 2000). This interaquifer flow has been estimated to occur to a lesser extent in Hays County relative to Comal, Bexar, and Medina Counties (Mace and others, 2000).

\section{Numerical and Statistical Methods}

The geochemical model PHREEQC (Parkhurst and Appelo, 1999) was used to calculate equilibrium concentrations of chemical species in solution, for speciation modeling, and to simulate reactions and processes occurring in the aquifer. Speciation modeling determines the potential in natural waters for mineral dissolution or precipitation to occur by calculating the saturation index for specified minerals and phases. The precipitation or dissolution of mineral phases can be an important control on water composition. In a carbonate aquifer, such as the Edwards aquifer, the dissolution or precipitation of minerals such as calcite and dolomite, which compose the aquifer rocks, will add or remove associated constituents (such as calcium [Ca], magnesium $[\mathrm{Mg}]$, strontium [Sr], and bicarbonate $\left.\left[\mathrm{HCO}_{3}\right]\right)$. The dissolution or precipitation of common trace minerals in carbonate rocks, such as celestite or gypsum, can also affect water composition. Gypsum is present in Edwards Group rocks (Maclay and Small, 1983) and might affect groundwater sulfate $\left(\mathrm{SO}_{4}\right) /$ chloride $(\mathrm{Cl})$ ratios and $\mathrm{SO}_{4}$ concentrations. Saturation index values were evaluated for aragonite, calcite, celestite, dolomite, gypsum, and strontianite and for carbon dioxide and dissolved oxygen gas phases.

Inverse modeling with PHREEQC attempts to account for observed water compositions by (1) identifying thermodynamically feasible geochemical reactions and associated mass transfers of specified sources and sinks of major dissolved constituents and (2) quantifying mixing proportions of different initial solutions. Inverse modeling was used in this study to approximate mixing proportions of selected source (endmember) compositions and plausible geochemical reactions along a hypothetical flow path. An initial water composition or compositions (representing matrix groundwater) was mixed with other selected water compositions (representing surface-water recharge, salinezone groundwater, or Trinity aquifer water), and a final water composition was designated (representing San Marcos Springs discharge). Reactions along a hypothetical flow path with selected mineral and gas phases were allowed, and results were constrained by selected ion concentrations (for example, major ions and $\mathrm{Sr}$ ). Concentration uncertainties were defined, and the maximum uncertainty from the different model scenarios was considered in evaluating results; models with relatively low uncertainties $(<0.05$, or 5 percent) were considered a better geochemical fit and, thus, more hydrologically plausible. No model results that required an uncertainty greater than 10 percent were considered. All models included phases likely to be associated with carbonate aquifers and specifically with the Edwards aquifer (calcite, dolomite, gypsum, quartz, carbon dioxide, dissolved oxygen, and phases for $\mathrm{Ca}$ and sodium $[\mathrm{Na}]$ cation exchange). Dolomite and gypsum were constrained to allow for only dissolution (no precipitation). Dissolved oxygen was constrained to allow for only its loss or consumption. Resulting mixing-reaction models are valid within the constraints of available thermodynamic data and the data considered for initial and final water compositions.

Nonparametric statistical tests were used for most data interpretation. Water-resources data are commonly nonnormally distributed (Helsel and Hirsch, 2002), and as a result, traditional parametric statistical methods are less suited to evaluate water-resources data than are nonparametric tests. The Kendall's tau test was used to measure correlation. The Kendall's tau coefficient is a nonparametric, rank-based test used to measure the strength of the relation between $\mathrm{x}$ and $y$ (linear and nonlinear) and is resistant to the effects of outliers (Helsel and Hirsch, 2002). The tau coefficient ranges from -1 to 1 ; a value of 0 indicates no correlation, and values approaching -1 or 1 indicate an increasing strength of correlation. The tau coefficient values generally will be lower than values of traditional correlation coefficients for linear associations of the same strength; for example, a strong linear correlation of greater than or equal to 0.9 corresponds to a tau value of greater than or equal to about 0.7 (Helsel and Hirsch, 2002). The Mann-Whitney U test, a nonparametric 
test for comparing two independent groups of data, was used to test for differences. For this report, statistical results with probability values ( $\mathrm{p}$-values) less than $0.05(\mathrm{p}<0.05)$ are considered statistically significant.

\section{Climatic and Hydrologic Conditions}

Climatic and hydrologic conditions during the study varied considerably, which offered an opportunity to investigate changes in water quality at San Marcos Springs in response to drought and relatively wet conditions and the transition between the two. Climatic and hydrologic conditions during the study period ranged from exceptional drought (U.S. Drought Monitor, 2011) — with sustained small amounts of rainfall, surface-water flow, and discharge at major springs (Comal, San Marcos and Hueco Springs) - to relatively wet conditions with regularly occurring rainfall, greater surfacewater flow, and above-average discharge at major springs (fig. 5). When water-quality sampling began in December 2008, dry conditions had prevailed through the prior spring and summer, resulting in a decrease in discharge at San Marcos Springs from the largest value for the year of $217 \mathrm{ft}^{3} / \mathrm{s}$ on January 1, 2008, to $102 \mathrm{ft}^{3} / \mathrm{s}$ on December 1, 2008, when the first sample was collected. Dry conditions persisted until early September 2009, resulting in discharge at San Marcos Springs falling to $86 \mathrm{ft}^{3} / \mathrm{s}$. During the dry period, 12.7 inches of rain fell in the study area; San Marcos Springs discharge ranged from $83 \mathrm{ft}^{3} / \mathrm{s}$ to $106 \mathrm{ft}^{3} / \mathrm{s}$, with an average discharge of 95 $\mathrm{ft}^{3} / \mathrm{s}$; discharge for Blanco at Halifax ranged from $2.3 \mathrm{ft}^{3} / \mathrm{s}$ to $36 \mathrm{ft}^{3} / \mathrm{s}$, with an average discharge of $9.4 \mathrm{ft}^{3} / \mathrm{s}$ (monitoring at Blanco at Halifax started on December 19, 2008). In contrast, during the wet period, 60.7 inches of rain fell in the study area; San Marcos Springs discharge ranged from $88 \mathrm{ft}^{3} / \mathrm{s}$ to $270 \mathrm{ft}^{3} / \mathrm{s}$, with an average discharge of $202 \mathrm{ft}^{3} / \mathrm{s}$; discharge for Blanco at Halifax ranged from $14 \mathrm{ft}^{3} / \mathrm{s}$ to an estimate of $3,620 \mathrm{ft}^{3} / \mathrm{s}$, with an average discharge of $204 \mathrm{ft}^{3} / \mathrm{s}$ (approximately 20 times larger than during the dry period).

\section{Storm Characteristics}

The three major storms that were sampled during this study varied in size, antecedent moisture conditions, and resulting stream (discharge and recharge) and spring (discharge) response (table 3; fig. 6). Storm 1 marked the transition from the dry period to the wet period and followed the driest antecedent moisture conditions. Storm 1 was intermediate between storms 2 and 3 with respect to both the amount of rainfall and the discharge response at San Marcos Springs and Comal Springs. The discharge response and estimated recharge values for the Blanco River were similar for storms 1 and 2, which were smaller than storm 3. The discharge response for Hueco Springs was similar for all three storms and was characterized by a rapid rise in discharge relative to a more muted increase at San Marcos Springs and Comal Springs (fig. 6). Storms 2 and 3 followed similar antecedent moisture conditions (table 3). Storm 3, which was a named tropical cyclone storm (Hermine) (National Aeronautics and Space Administration, 2012), was the largest storm to occur during the study period with respect to rain amount, and it resulted in the largest streamflows and largest recharge estimates for the Blanco River and Cibolo Creek. For Dry Comal Creek, storms 2 and 3 resulted in larger flows than did storm 1; unlike the other evaluated streams, discharge and estimated recharge were larger for storm 2 than for storm 3 . Some flow occurred at Sink Creek during storm 2 but not at Purgatory Creek. In response to storm 3, some flow occurred at both Sink Creek and Purgatory Creek.

In addition to the three sampled storms, there were other storms that occurred during the study that generated large changes in discharge and estimated aquifer recharge (fig. 5; table 4). On June 9, 2010, a geographically isolated rain event occurred near New Braunfels, Tex. The average rainfall for the study area on that day was 2.91 inches, but 6.59 inches was recorded at New Braunfels, and 3.98 inches was recorded at Canyon Dam (NWS Cooperative stations 416276 and 411429 , respectively). This rain event resulted in very large discharge values on the Guadalupe River and Dry Comal Creek, with only small changes in discharge and estimated recharge for the Blanco River and Cibolo Creek. This event was well suited to investigate potential recharge to San Marcos Springs from the Guadalupe River and Dry Comal Creek; estimated recharge from Dry Comal Creek was large in response to this rain event (fig. 7), whereas gain-loss estimates indicate that the Guadalupe River was gaining (fig. 8). The lack of response in physicochemical properties at San Marcos Springs indicates that these streams likely do not contribute notably to San Marcos Springs discharge.

\section{Rainfall Characteristics}

Stable isotope results for rainfall samples collected at the USGS South Texas Program office in San Antonio (USGS station 293146982941) covered a large range: $\delta D$ values ranged from -139.0 to 8.9 parts per thousand (per mil), and $\delta^{18} \mathrm{O}$ values ranged from -19.13 to -0.32 per mil. These data are consistent with a meteoric origin based on 
Table 3. Characteristics of sampled storms, antecedent moisture conditions, and hydrologic response in the vicinity of San Marcos Springs, south-central Texas

(November 2008-December 2010).

$\left[\mathrm{ft}^{3} / \mathrm{s}\right.$, cubic feet per second; >, greater than; \%, percent; max., maximum]

\begin{tabular}{|c|c|c|c|c|c|c|c|c|}
\hline \multicolumn{4}{|c|}{ Storm description } & \multicolumn{2}{|c|}{$\begin{array}{c}\text { Antecedent moisture } \\
\text { conditions }^{1}\end{array}$} & \multicolumn{3}{|c|}{ Hydrologic response $^{2}$} \\
\hline Storm & $\begin{array}{c}\text { Date of storm } \\
\text { onset }\end{array}$ & $\begin{array}{c}\text { Total } \\
\text { (inches) }^{1}\end{array}$ & $\begin{array}{c}\text { Temporal distribution } \\
\text { of rainfall }\end{array}$ & $\begin{array}{c}\text { Rainfall } \\
\text { in prior } 3 \\
\text { months } \\
\text { (inches) }{ }^{1}\end{array}$ & $\begin{array}{l}\text { Days since } \\
\text { last storm } 1 \\
(>1 \text { inch of } \\
\text { rain in a day) }\end{array}$ & $\begin{array}{c}\text { Spring discharge } \\
\text { response (prestorm value } \\
\text { to } 10-\mathrm{day} \text { poststorm max.): } \\
\mathrm{ft}^{3} / \mathrm{s} \text { ( } \% \text { change) }\end{array}$ & $\begin{array}{l}\text { Stream discharge response } \\
\text { (prestorm value to } 7 \text {-day } \\
\text { poststorm max.): } \mathrm{ft}^{3} / \mathrm{s}\end{array}$ & $\begin{array}{l}\text { Estimated stream recharge } \\
\left(\mathrm{ft}^{3} / \mathrm{s}\right) \text { : range (5-day total) }\end{array}$ \\
\hline 1 & 9/9/2009 & 5.4 & $\begin{array}{l}5.4 \text { inches of rain fell } \\
\text { between } 9 / 9 \text { and } \\
\text { 9/13; largest } \\
\text { proportion on any } \\
\text { day was } 39 \% \text {, } \\
\text { which fell on } 9 / 11\end{array}$ & 2.5 & 134 & $\begin{array}{l}\text { San Marcos Springs: } \\
86 \text { to } 97(13 \%) \text {; Comal } \\
\text { Springs: } 173 \text { to } 210 \\
\text { (21\%); Hueco Springs: } \\
4.1 \text { to } 101(2,363 \%)\end{array}$ & $\begin{array}{l}\text { Blanco at Halifax: } 2.8 \text { to } 211 \text {; } \\
\text { Guadalupe at Sattler: } 57 \text { to } \\
\text { 105; Sink Creek: no flow; } \\
\text { Purgatory Creek: no flow; } \\
\text { Cibolo near Boerne: } 1.9 \text { to } \\
\text { 8.3; Dry Comal: } 0 \text { to } 680\end{array}$ & $\begin{array}{l}\text { Blanco River': } 0.8 \text { to } 83.9 \\
\text { (318); Cibolo Creek: } 1.6 \\
\text { to } 7.0 \text { (22.2); Dry Comal } \\
\text { Creek: } 0 \text { to } 487 \text { (758) }\end{array}$ \\
\hline 2 & $10 / 3 / 2009$ & 2.5 & $\begin{array}{l}2.5 \text { inches of rain fell } \\
\text { between } 10 / 3 \text { and } \\
10 / 4 ; 91 \% \text { of rain } \\
\text { fell on } 10 / 4 ; \text { an } \\
\text { additional } 2.2 \\
\text { inches of rain fell } \\
\text { between } 10 / 9 \text { and } \\
10 / 14\end{array}$ & 10.2 & 20 & $\begin{array}{l}\text { San Marcos Springs: } \\
96 \text { to } 147(53 \%) \text {; Comal } \\
\text { Springs: } 210 \text { to } 274 \\
(30 \%) \text {; Hueco Springs: } \\
17 \text { to } 115(576 \%)\end{array}$ & $\begin{array}{l}\text { Blanco at Halifax: } 21 \text { to } 220 ; \\
\text { Guadalupe at Sattler: } 69 \text { to } \\
\text { 104; Sink Creek: } 0 \text { to } 9.8 \\
\text { (estimated); Purgatory Creek: } \\
\text { no flow; Cibolo near Boerne: } \\
1.8 \text { to } 34 \text {; Dry Comal: } 0.06 \\
\text { to } 3,500\end{array}$ & $\begin{array}{l}\text { Blanco River': } 6.2 \text { to } 92.3 \\
\text { (253); Cibolo Creek: } \\
\text { 1.5 to } 2,053(2,263) ; \\
\text { Dry Comal Creek: } 7.4 \\
\text { to } 10,022(13,452)\end{array}$ \\
\hline 3 & 9/7/2010 & 8.1 & $\begin{array}{l}8.1 \text { inches of rain fell } \\
\text { between } 9 / 7 \text { and } \\
9 / 9 ; 77 \% \text { of rain } \\
\text { fell on } 9 / 8 ; \text { storm } \\
\text { was a named } \\
\text { tropical storm } \\
\text { (Hermine) }\end{array}$ & 10.1 & 4 & $\begin{array}{l}\text { San Marcos Springs: } \\
207 \text { to } 223(8 \%) \text {; Comal } \\
\text { Springs: } 313 \text { to } 348 \\
\text { (11\%); Hueco Springs: } \\
34 \text { to } 121(256 \%)\end{array}$ & $\begin{array}{l}\text { Blanco at Halifax: } 46 \text { to } 3,620 \text {; } \\
\text { Guadalupe at Sattler: } 201 \text { to } \\
\text { 1,090 ( } 9 \text { day); Sink Creek: } \\
0 \text { to } 25 \text {; Purgatory Creek, } \\
\text { some flow }{ }^{3} \text {; Cibolo near } \\
\text { Boerne: } 3.8 \text { to } 835 \text {; Dry } \\
\text { Comal: } 0.7 \text { to } 2,660\end{array}$ & $\begin{array}{l}\text { Blanco River }{ }^{4}: 5.2 \text { to } 538 \\
\text { (1,049); Cibolo Creek: } \\
\text { 6.1 to 3,200 (6,711); } \\
\text { Dry Comal Creek: } \\
38.4 \text { to } 3,607(4,995)\end{array}$ \\
\hline
\end{tabular}

${ }^{1}$ Rainfall data from National Climatic Data Center for six National Weather Service meteorological stations (cooperative stations: Canyon Dam [411429], Dripping Springs 6 E [412585],

New Braunfels [416276], San Marcos [417983], Spring Branch 2se [418544], and Wimberley 1 NW [419815]) (National Oceanic and Atmospheric Administration, 2011); daily rainfall values

for these sites were averaged to obtain a composite rainfall record in the vicinity of San Marcos Springs.

${ }^{2}$ Short names are used here; see table 1 for complete U.S. Geological Survey station names and numbers.

${ }^{3}$ Gage height at Purgatory Creek rose from 0.06 to 1.7 feet; stage-discharge relation not determined for this site.

${ }^{4}$ Based on Halifax-to-Kyle method as described in the report in section "Streamflow Measurements and Recharge Estimation." 
A
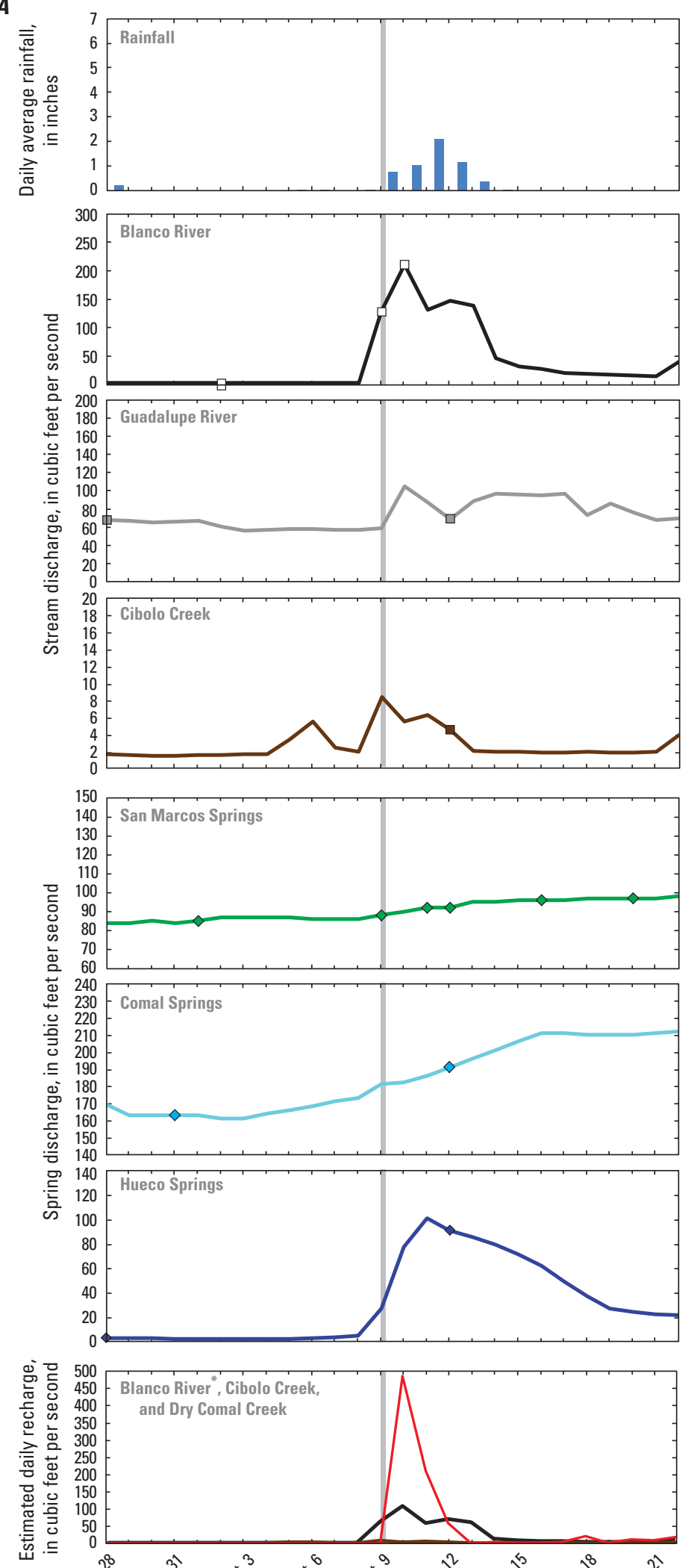

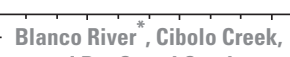
and Dry Comal Creek

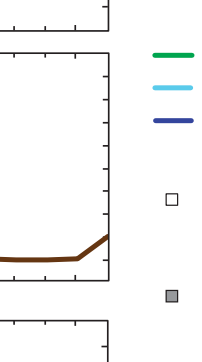

$$
\text { . }
$$

$$
\text { . }
$$

- Cib

\section{EXPLANATION}

Onset of major storm

Discharge at surface-water site, by stream

- Blanco River-Halifax Ranch near Kyle, Texas (USGS station 08171290)

- Guadalupe River-Sattler, Tex. (USGS station 08167800)

- Cibolo Creek-Cibolo Nature Center near Boerne, Tex. (USGS station 08183890)

Discharge (daily mean) at spring - Composite of individual orifices (table 1)

- San Marcos Springs

- Comal Springs

- Hueco Springs

Sample, by stream or spring

- Blanco River-Sample collection at Halifax Ranch near Kyle, Tex. (USGS station 08171290)

Guadalupe River-Sample collection at River Road near Sattler, Tex. (USGS station 08167990)

Cibolo Creek-Sample collection at Farm Road 1863 below Bulverde, Tex. (USGS station 08184300)

- San Marcos Springs-Sample collection at Deep and Diversion Springs (USGS stations 295322097561000 and 295336097555201 , respectively)

- Comal Springs-Sample collection at Comal Spring 1 (USGS station 294300098080001)

- Hueco Springs-Sample collection at Hueco Spring A (USGS station 294533098082301)

USGS, U.S. Geological Survey

\section{EXPLANATION}

\section{Onset of major storm}

Estimated recharge, by stream

\section{- Blanco River \\ - Cibolo Creek \\ — Dry Comal Creek}

* Based on Wimberley-to-Kyle method as described in the report in section "Streamflow Measurements and Recharge Estimation."

Figure 6. Rainfall hyetograph, hydrographs for streams and springs, estimated stream recharge, and timing of collection of stream and spring samples for storms in the vicinity of San Marcos Springs, south-central Texas. A, Storm 1 (September 2009). B, Storm 2 (0ctober 2009). C, Storm 3 (September 2010). 
B
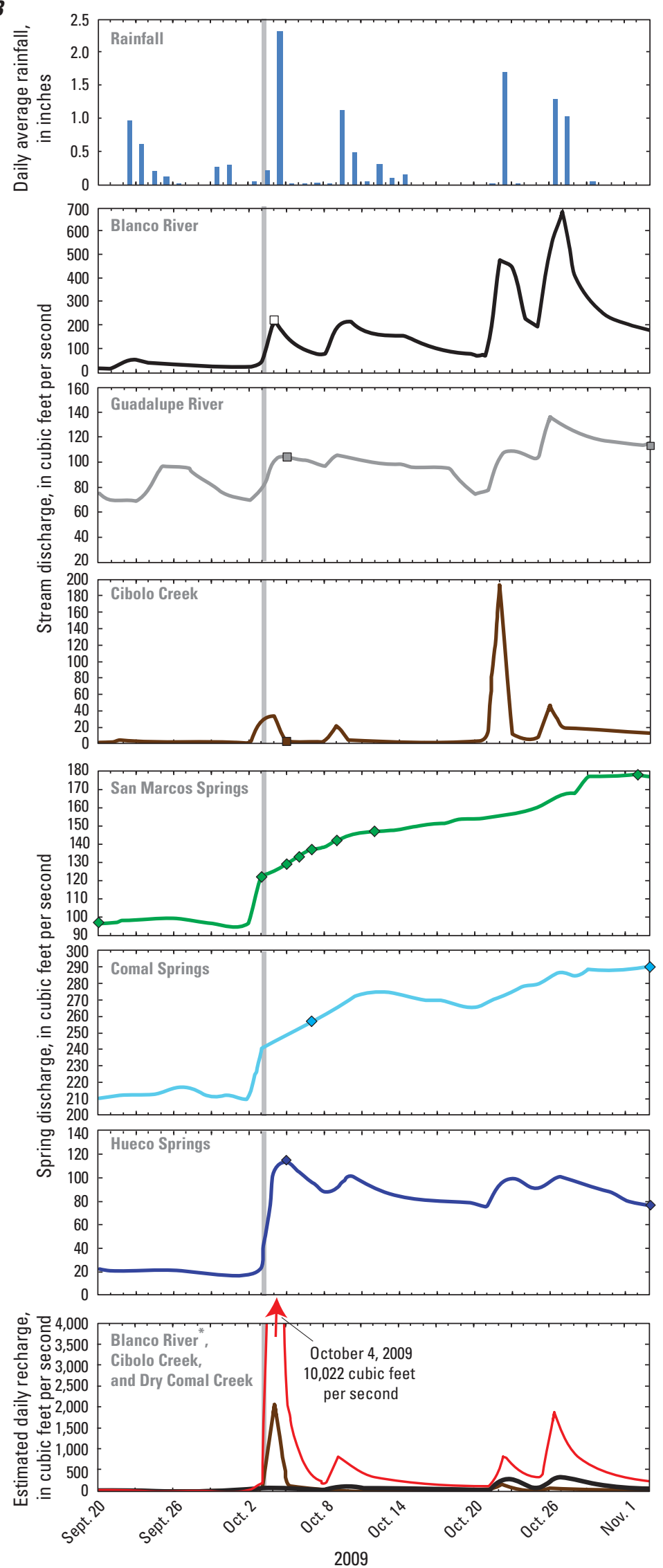

\section{EXPLANATION}

Onset of major storm

Discharge at surface-water site, by stream

- Blanco River-Halifax Ranch near Kyle, Texas (USGS station 08171290)

- Guadalupe River-Sattler, Tex. (USGS station 08167800)

- Cibolo Creek-Cibolo Nature Center near Boerne, Tex. (USGS station 08183890)

Discharge (daily mean) at spring-Composite of individual orifices (table 1)

- San Marcos Springs

- Comal Springs

- Hueco Springs

Sample, by stream or spring

$\square \quad$ Blanco River-Sample collection at Halifax Ranch near Kyle, Tex. (USGS station 08171290)

- Guadalupe River-Sample collection at River Road near Sattler, Tex. (USGS station 08167990)

- Cibolo Creek-Sample collection at Farm Road 1863 below Bulverde, Tex. (USGS station 08184300)

$\diamond \quad$ San Marcos Springs-Sample collection at Deep and Diversion Springs (USGS stations 295322097561000 and 295336097555201 , respectively)

$\diamond \quad$ Comal Springs-Sample collection at Comal Spring 1 (USGS station 294300098080001)

- Hueco Springs-Sample collection at Hueco Spring A (USGS station 294533098082301)

USGS, U.S. Geological Survey

\section{EXPLANATION}

Onset of major storm

Estimated recharge, by stream

$$
\begin{array}{ll}
\text { - Blanco River } \\
\text { - } & \text { Cibolo Creek } \\
\text { Dry Comal Creek }
\end{array}
$$

* Based on Wimberley-to-Kyle method as described in the report in section "Streamflow Measurements and Recharge Estimation."

Figure 6. Rainfall hyetograph, hydrographs for streams and springs, estimated stream recharge, and timing of collection of stream and spring samples for storms in the vicinity of San Marcos Springs, south-central Texas. A, Storm 1 (September 2009). B, Storm 2 (October 2009). C, Storm 3 (September 2010). - Continued 

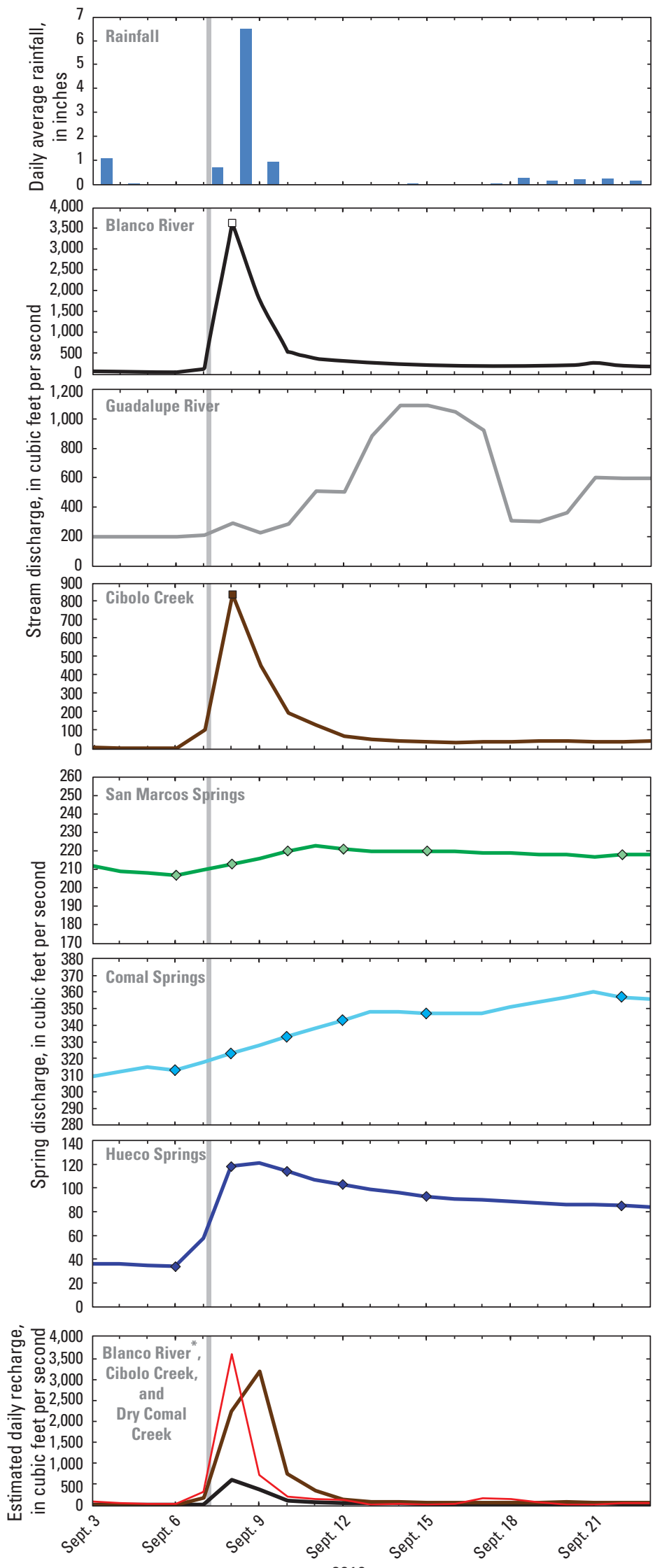

\section{EXPLANATION}

Onset of major storm

Discharge at surface-water site, by stream

- Blanco River-Halifax Ranch near Kyle, Texas (USGS station 08171290)

- Guadalupe River-Sattler, Tex. (USGS station 08167800)

- Cibolo Creek-Cibolo Nature Center near Boerne, Tex. (USGS station 08183890)

Discharge (daily mean) at spring — Composite of individual orifices (table 1)

— San Marcos Springs

- Comal Springs

- Hueco Springs

Sample, by stream or spring

$\square \quad$ Blanco River-Sample collection at Halifax Ranch near Kyle, Tex. (USGS station 08171290), and sample collection near Kyle, Tex. (USGS station 08171300)

- Cibolo Creek-Sample collection at Farm Road 1863 below Bulverde, Tex. (USGS station 08184300)

$\diamond \quad$ San Marcos Springs-Sample collection at Deep, Diversion, and Weissmuller Springs (USGS stations 295322097561000 , 295336097555201, and 295322097561002 , respectively)

$\diamond \quad$ Comal Springs-Sample collection at Comal Spring 1 (USGS station 294300098080001)

- Hueco Springs-Sample collection at Hueco Spring A (USGS station 294533098082301)

USGS, U.S. Geological Survey

\section{EXPLANATION}

Onset of major storm

Estimated recharge, by stream

- Blanco River

- Cibolo Creek

- Dry Comal Creek

* Based on Wimberley-to-Kyle method as described in the report in section "Streamflow Measurements and Recharge Estimation."

Figure 6. Rainfall hyetograph, hydrographs for streams and springs, estimated stream recharge, and timing of collection of stream and spring samples for storms in the vicinity of San Marcos Springs, south-central Texas. A, Storm 1 (September 2009). B, Storm 2 (October 2009). C, Storm 3 (September 2010). - Continued 
Table 4. Characteristics of unsampled storms, antecedent moisture conditions, and hydrologic response in the vicinity of San Marcos Springs, south-central Texas

(November 2008-December 2010).

$\left[\mathrm{ft}^{3} / \mathrm{s}\right.$, cubic feet per second; >, greater than; \%, percent; max., maximum]

\begin{tabular}{|c|c|c|c|c|c|c|c|}
\hline \multirow[b]{2}{*}{$\begin{array}{c}\text { Date of } \\
\text { storm onset }\end{array}$} & \multirow[b]{2}{*}{$\begin{array}{c}\text { Total } \\
\text { (inches) }\end{array}$} & \multirow[b]{2}{*}{$\begin{array}{l}\text { Temporal } \\
\text { distribution of } \\
\text { rainfall }\end{array}$} & \multicolumn{2}{|c|}{$\begin{array}{l}\text { Antecedent moisture } \\
\text { conditions }^{1}\end{array}$} & \multicolumn{3}{|c|}{ Hydrologic response ${ }^{2}$} \\
\hline & & & $\begin{array}{c}\text { Rainfall } \\
\text { in prior } 3 \\
\text { months } \\
\text { (inches)' }\end{array}$ & $\begin{array}{l}\text { Days since } \\
\text { last storm } 1 \\
\text { (>1 inch } \\
\text { of rain in } \\
\text { a day) }\end{array}$ & $\begin{array}{c}\text { Spring discharge } \\
\text { response (prestorm value } \\
\text { to } 10-\text { day poststorm max.): } \\
\mathrm{ft}^{3} / \mathrm{s} \text { ( } \% \text { change) }\end{array}$ & $\begin{array}{l}\text { Stream discharge response (prestorm } \\
\text { value to } 7 \text {-day poststorm max.): } \mathrm{ft}^{3} / \mathrm{s}\end{array}$ & $\begin{array}{l}\text { Estimated stream recharge } \\
\left(\mathrm{ft}^{3} / \mathrm{s}\right) \text { : range (5-day total } \\
\text { unless otherwise noted) }\end{array}$ \\
\hline $10 / 22 / 2009$ & 4 & $\begin{array}{l}\text { Not a continuous } \\
\text { rain event: } 1.69 \\
\text { inches on } 10 / 22, \\
\text { followed by } \\
\text { additional } 2.31 \\
\text { inches on } 10 / 26 \\
\text { through } 10 / 27\end{array}$ & 14.7 & 13 & $\begin{array}{l}\text { San Marcos Springs: } \\
155 \text { to } 178(15 \%) ; \\
\text { Comal Springs } \\
268 \text { to } 290(8 \%) ; \\
\text { Hueco Springs: } 76 \\
\text { to } 102(34 \%)\end{array}$ & $\begin{array}{l}\text { Blanco at Halifax: } 69 \text { to } 680 \text {; Guadalupe at } \\
\text { Sattler: } 77 \text { to } 136 \text {; Sink Creek: no flow; } \\
\text { Purgatory Creek: no flow; Cibolo near } \\
\text { Boerne: } 8.5 \text { to } 193 \text {; Dry Comal Creek: } \\
1.1 \text { to } 181\end{array}$ & $\begin{array}{l}\text { Blanco River }{ }^{3}: 26 \text { to } 382 \\
\text { (1,380); Cibolo Creek: } \\
7.2 \text { to } 184 \text { (296); Dry } \\
\text { Comal: } 105 \text { to } 1,879 \\
\text { (5,096) (6-day totals) }\end{array}$ \\
\hline $11 / 20 / 2009$ & 1.6 & $\begin{array}{l}0.47 \text { inches of } \\
\text { rain on } 11 / 20, \\
\text { followed by } \\
\text { additional } 1.08 \\
\text { inches on } 11 / 21\end{array}$ & 19.2 & 24 & $\begin{array}{l}\text { San Marcos Springs: } \\
178 \text { to } 184(3 \%) ; \\
\text { Comal Springs } 290 \\
\text { to } 312(8 \%)(13 \text { days); } \\
\text { Hueco Springs: } 60 \\
\text { to } 75(23 \%)\end{array}$ & $\begin{array}{l}\text { Blanco at Halifax: } 123 \text { to } 631 \text {; Guadalupe at } \\
\text { Sattler: } 109 \text { to 114; Sink Creek: no flow; } \\
\text { Purgatory Creek: no flow; Cibolo near } \\
\text { Boerne: } 11 \text { to } 81 \text {; Dry Comal Creek: } \\
1.1 \text { to } 232\end{array}$ & $\begin{array}{l}\text { Blanco River }{ }^{3}: 56 \text { to } 343 \\
\text { (836); Cibolo Creek: } 8.9 \\
\text { to } 69 \text { (155); Dry Comal: } \\
140 \text { to } 764(1,863)\end{array}$ \\
\hline $1 / 14 / 2010$ & 2.5 & $\begin{array}{l}0.21 \text { inches of rain } \\
\text { on } 1 / 14,1.39 \\
\text { inches on } 1 / 15, \\
\text { followed by } \\
\text { additional } 0.93 \\
\text { inches on } 1 / 16\end{array}$ & 9.8 & 53 & $\begin{array}{l}\text { San Marcos Springs: } \\
181 \text { to } 207(14 \%) ; \\
\text { Comal Springs } 309 \\
\text { to } 340(10 \%)(13 \\
\text { days); Hueco } \\
\text { Springs: } 22 \\
\text { to } 98(345 \%)\end{array}$ & $\begin{array}{l}\text { Blanco at Halifax: } 116 \text { to } 1,210 \text {; Guadalupe } \\
\text { at Sattler: } 102 \text { to } 113 \text {; Sink Creek: no flow; } \\
\text { Purgatory Creek: no flow; Cibolo near } \\
\text { Boerne: } 20 \text { to } 105 \text {; Dry Comal Creek: } \\
1.1 \text { to } 707\end{array}$ & $\begin{array}{l}\text { Blanco River }{ }^{3}: 15 \text { to } 201 \\
\text { (471); Cibolo Creek: } \\
31 \text { to } 210 \text { (530); Dry } \\
\text { Comal: } 46 \text { to } 589 \\
(1,355)\end{array}$ \\
\hline $1 / 28 / 2010$ & 3.1 & $\begin{array}{l}\text { Not a single rain } \\
\text { event; } 1.24 \text { inches } \\
\text { from } 1 / 28 \text { through } \\
1 / 30 ; \text { followed by } \\
\text { additional } 1.79 \\
\text { inches from } 2 / 3 \\
\text { through } 2 / 5\end{array}$ & 8.2 & 13 & $\begin{array}{l}\text { San Marcos Springs: } \\
209 \text { to } 264(26 \%) ; \\
\text { Comal Springs } \\
338 \text { to } 364(8 \%) ; \\
\text { Hueco Springs: } 86 \\
\text { to } 113(31 \%)\end{array}$ & $\begin{array}{l}\text { Blanco at Halifax: } 280 \text { to } 1,780 \text {; Guadalupe } \\
\text { at Sattler: } 108 \text { to } 119 \text {; Sink Creek: no flow; } \\
\text { Purgatory Creek: no flow; Cibolo near } \\
\text { Boerne: } 43 \text { to } 407 \text {; Dry Comal Creek: } \\
3.4 \text { to } 636\end{array}$ & $\begin{array}{l}\text { Blanco River }{ }^{3}: 40 \text { to } 301 \\
\text { (1,622); Cibolo Creek: } \\
43 \text { to } 1,065(3,935) ; \\
\text { Dry Comal: } 54 \text { to } 551 \\
(2,141)(10 \text {-day totals })\end{array}$ \\
\hline
\end{tabular}


Table 4. Characteristics of unsampled storms, antecedent moisture conditions, and hydrologic response in the vicinity of San Marcos Springs, south-central Texas (November 2008-December 2010).-Continued

[fts/s, cubic feet per second; >, greater than; \%, percent; max., maximum]

\begin{tabular}{|c|c|c|c|c|c|c|c|}
\hline \multirow[b]{2}{*}{$\begin{array}{c}\text { Date of } \\
\text { storm onset }\end{array}$} & \multirow[b]{2}{*}{$\begin{array}{c}\text { Total } \\
\text { (inches) }{ }^{1}\end{array}$} & \multirow[b]{2}{*}{$\begin{array}{l}\text { Temporal } \\
\text { distribution of } \\
\text { rainfall }\end{array}$} & \multicolumn{2}{|c|}{$\begin{array}{c}\text { Antecedent moisture } \\
\text { conditions }^{1}\end{array}$} & \multicolumn{3}{|c|}{ Hydrologic response ${ }^{2}$} \\
\hline & & & $\begin{array}{c}\text { Rainfall } \\
\text { in prior } 3 \\
\text { months } \\
\text { (inches)' }\end{array}$ & $\begin{array}{l}\text { Days since } \\
\text { last storm } 1 \\
\text { (>1 inch } \\
\text { of rain in } \\
\text { a day) }\end{array}$ & $\begin{array}{c}\text { Spring discharge } \\
\text { response (prestorm value } \\
\text { to } 10-\text { day poststorm max.): } \\
\mathrm{ft}^{3} / \mathrm{s}(\% \text { change) }\end{array}$ & $\begin{array}{l}\text { Stream discharge response (prestorm } \\
\text { value to } 7 \text {-day poststorm max.): } \mathrm{ft}^{3} / \mathrm{s}\end{array}$ & $\begin{array}{l}\text { Estimated stream recharge } \\
\left(\mathrm{ft}^{3} / \mathrm{s}\right) \text { : range (5-day total } \\
\text { unless otherwise noted) }\end{array}$ \\
\hline $5 / 15 / 2010$ & 4.5 & $\begin{array}{l}\text { Not a continuous } \\
\text { rain event; } 3.13 \\
\text { inches from } 5 / 15 \\
\text { through } 5 / 16 ; \\
\text { followed by } \\
\text { additional } 1.33 \\
\text { inches on } 5 / 18\end{array}$ & 4.8 & 105 & $\begin{array}{l}\text { San Marcos Springs: } \\
233 \text { to } 235(1 \%) ; \\
\text { Comal Springs: } \\
341 \text { to } 359(5 \%) ; \\
\text { Hueco Springs: } 72 \\
\text { to } 108(50 \%)\end{array}$ & $\begin{array}{l}\text { Blanco at Halifax: } 139 \text { to } 347 \text {; Guadalupe at } \\
\text { Sattler: } 389 \text { to 2,580; Sink Creek: no flow; } \\
\text { Purgatory Creek: } 0 \text { to } 10 \text {; Cibolo near } \\
\text { Boerne: } 27 \text { to 582; Dry Comal Creek: } \\
25 \text { to } 575\end{array}$ & $\begin{array}{l}\text { Blanco River }{ }^{3}: 23 \text { to } 82 \\
\text { (327); Cibolo Creek: } \\
478 \text { to } 983 \text { (2,970); } \\
\text { Dry Comal: } 48 \text { to } 556 \\
(1,704) \text { (6 day totals) }\end{array}$ \\
\hline $6 / 9 / 2010$ & 3.0 & $\begin{array}{l}2.91 \text { inches of } \\
\text { rain (localized } \\
\text { rainfall of } 6.59 \\
\text { inches at New } \\
\text { Braunfels site) }\end{array}$ & 9.6 & 21 & $\begin{array}{l}\text { San Marcos Springs: } \\
222 \text { to } 228(3 \%) \text {; } \\
\text { Comal Springs: } \\
359 \text { to } 399(1 \%) \text {; } \\
\text { Hueco Springs: } 77 \\
\text { to } 86(12 \%)\end{array}$ & $\begin{array}{l}\text { Blanco at Halifax: } 136 \text { to } 265 \text {; Guadalupe at } \\
\text { Sattler: no flow increase (increase from } \\
523 \text { to } 7,930 \text { at downstream gage Guada- } \\
\text { lupe above Comal); Sink Creek: no flow; } \\
\text { Purgatory Creek: no flow; Cibolo near } \\
\text { Boerne: no flow increase; Dry Comal } \\
\text { Creek: } \\
1.8 \text { to } 3,050\end{array}$ & $\begin{array}{l}\text { Blanco River }{ }^{3}: 19 \text { to } 55 \\
\text { (152); Cibolo Creek: } 67 \\
\text { to } 77 \text { (289); Dry Comal: } \\
35 \text { to } 9,105(10,788)\end{array}$ \\
\hline
\end{tabular}

${ }^{1}$ Rainfall data from National Climatic Data Center for six National Weather Service meteorological stations (cooperative stations: Canyon Dam [411429], Dripping Springs 6 E [412585],

New Braunfels [416276], San Marcos [417983], Spring Branch 2se [418544], and Wimberley 1 NW [419815]) (National Oceanic and Atmospheric Administration, 2011); daily rainfall values for these sites were averaged to obtain a composite rainfall record in the vicinity of San Marcos Springs.

${ }^{2}$ Short names are used here; see table 1 for complete U.S. Geological Survey station names and numbers.

${ }^{3}$ Based on Halifax-to-Kyle method as described in the report in section "Streamflow Measurements and Recharge Estimation." 

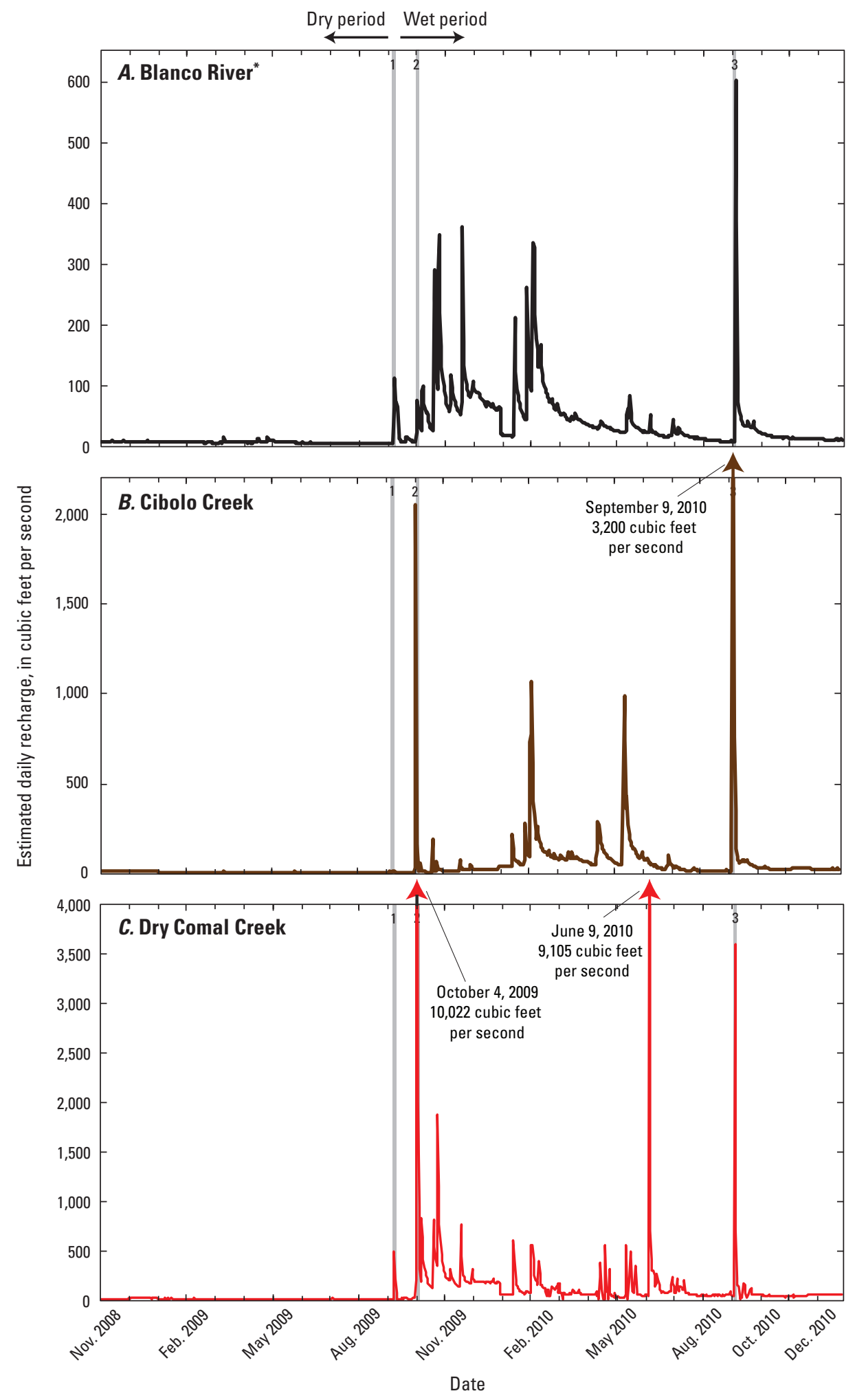

\section{EXPLANATION}

1 Onset of major storm and identifier

* Based on Wimberley-to-Kyle method as described in the report in section "Streamflow Measurements and Recharge Estimation."

Figure 7. Estimated recharge to the Edwards aquifer from $A$, the Blanco River, $B$, Cibolo Creek, and $C$, Dry Comal Creek, southcentral Texas, 2008-10. 

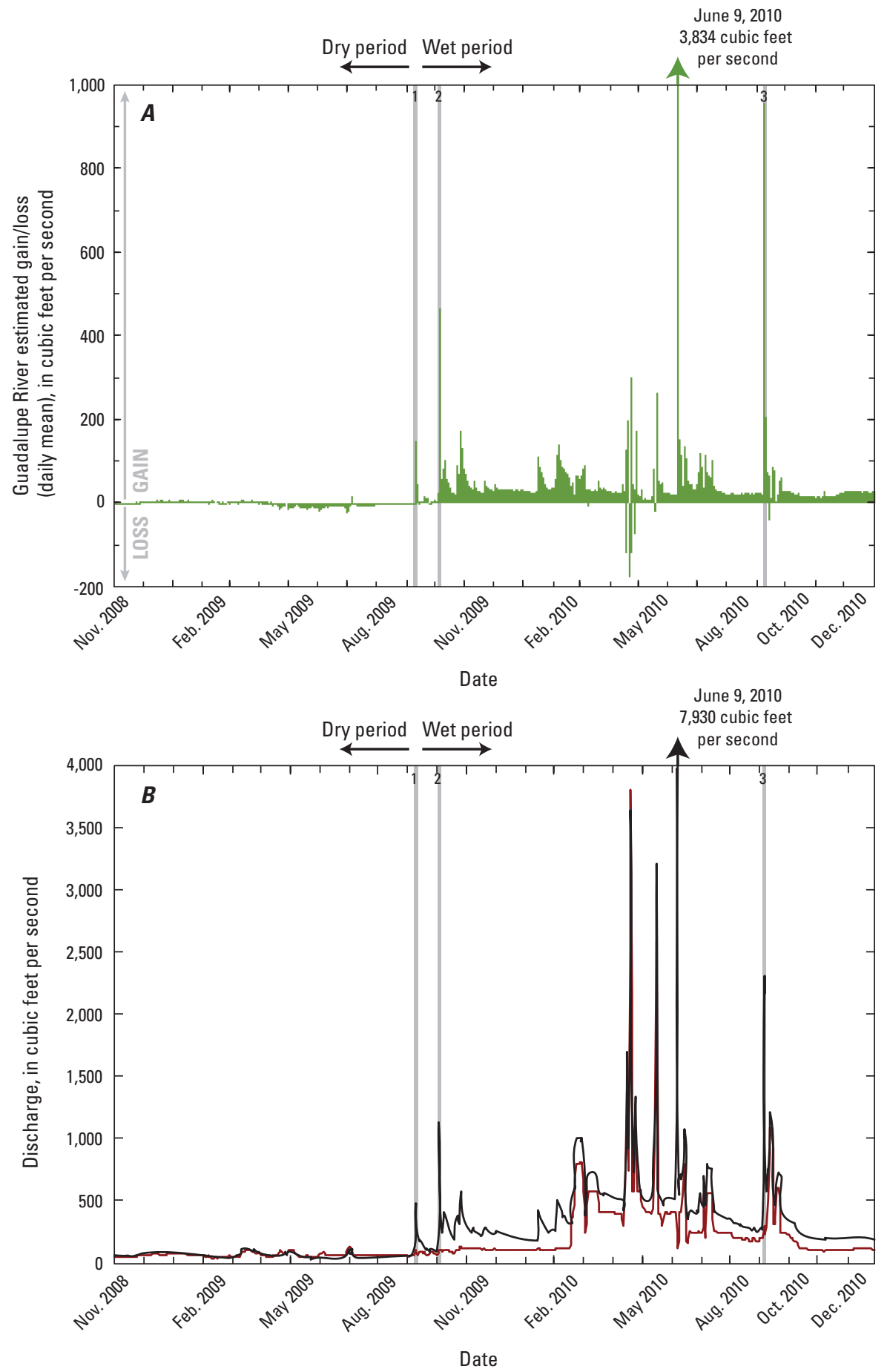

EXPLANATION

1 Onset of major storm and identifier

- Guadalupe River estimated gain/loss

_ Stream discharge at Guadalupe River at Sattler, Texas (USGS station 08167800)

— Stream discharge at Guadalupe River above Comal River at New Braunfels, Tex. (USGS station 08168500) USGS, U.S. Geological Survey

Figure 8. Time series (November 2008-December 2010) of gain (positive values) and loss (negative values) for the Guadalupe River, south-central Texas. A, Estimated stream gain (positive values) and loss (negative values). B, Stream discharge at two U.S. Geological Survey stations. 
comparison with the global meteoric water line (Craig, 1961) and the local meteoric water line (Pape and others, 2010) (fig. 9). Rainfall samples collected during the dry period had significantly higher median $\delta \mathrm{D}$ and $\delta^{18} \mathrm{O}$ values (5.1 and -0.94 per mil, respectively) than did samples collected during the wet period (-23.1 and -4.46 per mil, respectively). As discussed by Pape and others (2010), variations in meteoric precipitation in the midlatitudes can be controlled by a variety of factors, including temperature, rainfall amount, and the moisture source of individual rain events. When more than one sample was collected during the storms (storms 1 and 3), results showed a range of values (fig. 9). Rainfall amount is an important control on the isotopic composition of rain during summertime periods in central Texas (Pape and others, 2010). Rainfall stable isotope values from samples collected during this study correlate with rain amounts measured nearby at the San Antonio International Airport (NWS Cooperative Station 417945) (Kendall's tau $=-0.34$ and -0.46 for $\delta \mathrm{D}$ and $\delta^{18} \mathrm{O}$ values, respectively), indicating that lighter stable isotope values for rainfall were generally associated with larger events.

Stable isotope results for rainfall samples collected during storms 1-3 were different for the different storms. Stable isotope results for the single rain sample collected during storm $2\left(-23.1\right.$ and -4.2 per mil for $\delta \mathrm{D}$ and $\delta^{18} \mathrm{O}$, respectively) were similar to median values for San Marcos

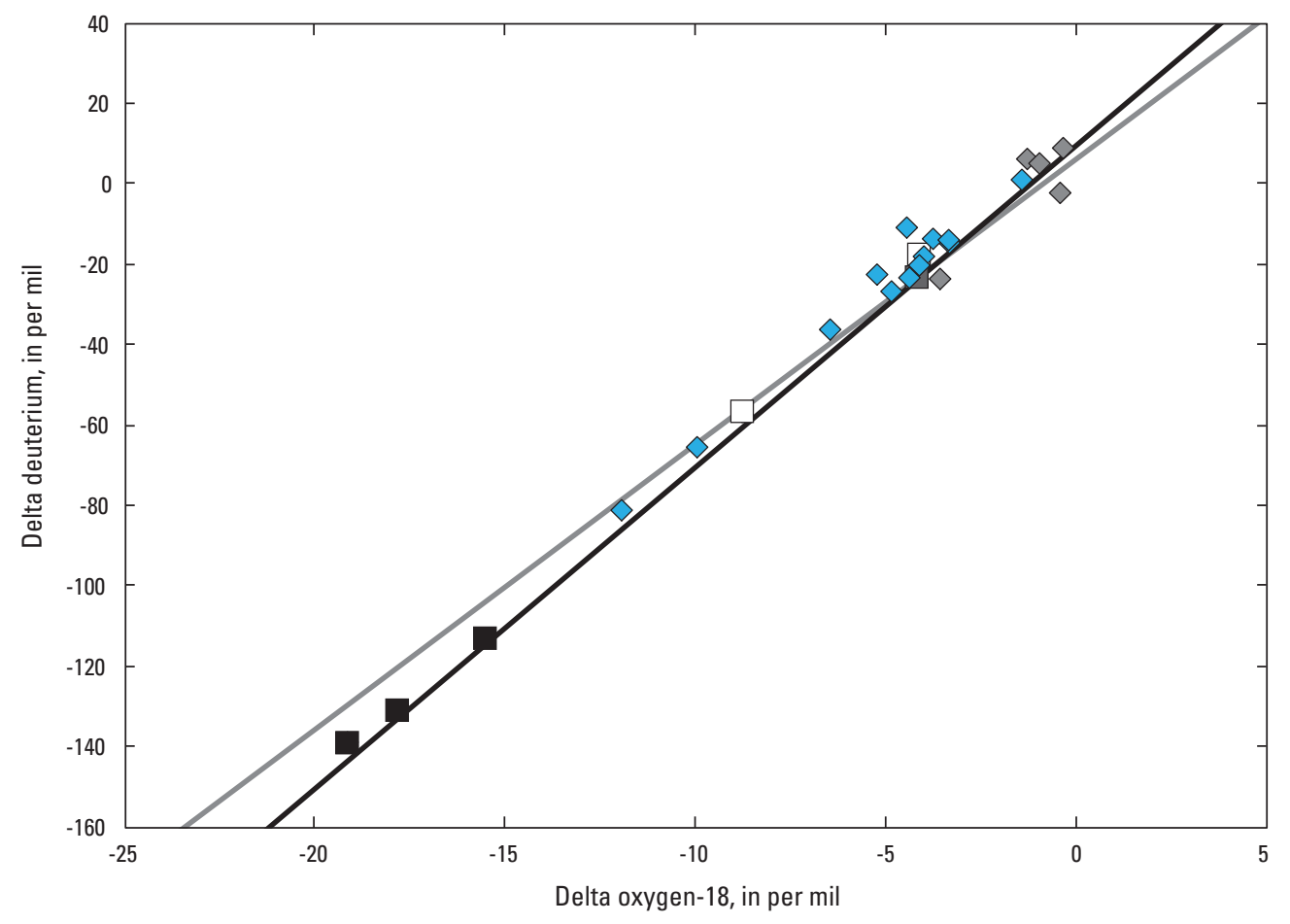

EXPLANATION

Global meteoric water line (Craig, 1961)
Local meteoric water line (Pape and others, 2010)
Rainfall sample
Dry period-November 1, 2008, to September 8, 2009
Wet period-September 9, 2009, to December 31, 2010
$\quad$ Storm 1-September, 2009
Storm 2-October, 2009
Storm 3-September, 2010

Figure 9. Relation between deuterium and oxygen isotopes for rainfall samples collected at U.S. Geological Survey station 293146982941, Bexar County, south-central Texas (2008-10). Local (Pape and others, 2010) and global (Craig, 1961) meteoric water lines are shown for comparison. 
Springs (table 5). In contrast, median stable isotope values for rain samples collected during storm 1 (-37.2 and -6.4 per mil for $\delta \mathrm{D}$ and $\delta^{18} \mathrm{O}$, respectively) and storm 3 (-131.0 and -17.8 per mil for $\delta \mathrm{D}$ and $\delta^{18} \mathrm{O}$, respectively) were isotopically distinct from most groundwater and spring discharge samples collected during the study (table 5). Rain samples collected during storm 3 in particular were isotopically lighter (lower isotopic values) than other rain samples collected during this study (fig. 9), as well as isotopically lighter than rain samples collected in Austin, Tex., over an 8-year period by Pape and others (2010). Rainfall from tropical cyclone storms such as storm 3 has been shown to have isotopically light stable isotope values relative to normal summer rainfall (Lawrence and Gedzelman, 1996; Lawrence, 1998). Recharge to the Edwards aquifer in response to storm 3 would likely reflect these low isotopic values and provide a tracer of recent recharge, as previously demonstrated in the Edwards aquifer by Musgrove and others (2010); this hypothesis is discussed further in the section "Endmember Mixing Using Conservative Tracers."

\section{Stream Recharge}

Installation of a streamflow-gaging station (Blanco at Halifax) for this study allowed for a detailed assessment of potential recharge to the Edwards aquifer from the Blanco River as it crosses the recharge zone, as well as for comparison of recharge in the Wimberley-to-Halifax and Halifax-to-Kyle reaches of the Blanco River. A comparison of estimated recharge between Wimberley-to-Kyle and Halifax-to-Kyle indicates that recharge estimates are generally similar for the two different methods, with a Kendall's tau of 0.94 (fig. 10).

Recharge estimates for major streams in the study area that might provide recharge to San Marcos Springs (Blanco River, Cibolo Creek, and Dry Comal Creek) indicate that the amount of recharge varied markedly through the study period (fig. 7). Based on average recharge estimates, Dry Comal Creek contributed the largest amount of recharge to the Edwards aquifer in the study area (average daily mean recharge of $102 \mathrm{ft}^{3} / \mathrm{s}$ ), followed by Cibolo Creek (average daily mean recharge of $46.9 \mathrm{ft}^{3} / \mathrm{s}$ ) and the Blanco River (average daily mean recharge of $28.4 \mathrm{ft}^{3} / \mathrm{s}$ ). Recharge estimates were small and similar for the different streams during the dry period (average daily mean recharge of 2.7, 3.0, and $2.3 \mathrm{ft}^{3} / \mathrm{s}$ for the Blanco River [Halifax-to-Kyle], Cibolo Creek, and Dry Comal Creek, respectively) and significantly larger during the wet period (average daily mean recharge of 44.2, 75.3, and $167.2 \mathrm{ft}^{3} / \mathrm{s}$ for the Blanco River [Halifax-toKyle], Cibolo Creek and the Dry Comal River, respectively).
Recharge estimates varied between the streams for different events (fig. 7); for example, estimated recharge for Cibolo and Dry Comal Creeks were much larger than for the Blanco River in response to storm 2.

A gain-loss summary was estimated for the Guadalupe River between the Guadalupe at Sattler and Guadalupe above Comal stations. These results indicated that the Guadalupe River was largely a gaining stream for most of the study (fig. 8) with a daily mean gain that averaged $27.2 \mathrm{ft}^{3} / \mathrm{s}$. During the wet period, the Guadalupe River was a gaining stream for all but 7 days ( 1.5 percent of the wet period), with a daily mean gain that averaged $47.0 \mathrm{ft}^{3} / \mathrm{s}$. The largest losses occurred during several days in mid-April 2010, with a maximum daily mean loss of $178.2 \mathrm{ft}^{3} / \mathrm{s}$. This period coincided with some of the largest streamflow on the Guadalupe River during the study (fig. 8), although similar streamflow losses did not occur during other large streamflow events during the wet period (for example, mid-May 2010 and mid-September 2010). In contrast to the wet period, during the dry period the Guadalupe River was, on average, a losing stream, with an average value for daily mean loss of $3.0 \mathrm{ft}^{3} / \mathrm{s}$ (ranging from a maximum daily mean loss of $26.0 \mathrm{ft}^{3} / \mathrm{s}$ to a maximum daily mean gain of $13.6 \mathrm{ft}^{3} / \mathrm{s}$ ). For most of summer 2009 (dry period), the Guadalupe River had small daily mean losses $\left(8.4 \mathrm{ft}^{3} / \mathrm{s}\right.$ on average for May through August) (fig. 8). While these results indicate that during dry hydrologic conditions the Guadalupe River might contribute small amounts of recharge to the aquifer, they are consistent with the hypothesis that the Guadalupe River does not contribute substantial recharge to the Edwards aquifer (Puente, 1978) or to San Marcos Springs based on the low flow volumes.

Two ephemeral streams in the study area (Sink Creek and Purgatory Creek) were monitored for streamflow during the study (2009-10) (fig. 1). Discharge for Sink Creek was estimated from data collected at USGS station 08169932 Sink Creek near San Marcos, Tex. (hereinafter, Sink Creek; fig. 1, map identifier Q4) from May 21, 2009, through the end of 2010. Sink Creek flowed at the gaged location on only 3 days (Crow, 2012). In response to storm 2, discharges of 9.8 (estimated) and $8.9 \mathrm{ft}^{3} / \mathrm{s}$ on October 3 and 4, 2009, respectively, were measured for Sink Creek. In response to storm 3, Sink Creek discharge was $25 \mathrm{ft}^{3} / \mathrm{s}$ on September 8, 2010. Gage height for Purgatory Creek was collected at USGS station 08169958 (Purgatory Creek at Mountain High Drive near San Marcos, Tex.; hereinafter, Purgatory Creek; fig. 1, map identifier Q5) from August 12, 2009, through the end of 2010. Although data did not allow for a stage-discharge relation to be established for this site, gageheight records indicate that minor flow occurred in Purgatory Creek on only 2 days: May 16, 2010, and September 9, 2010 (in response to storm 3). 
Table 5. Summary statistics for discharge, physicochemical properties, and selected geochemical constituents for surface-water, groundwater, and spring sites sampled during dry and wet hydrologic conditions in the vicinity of San Marcos Springs, south-central Texas (November 2008-December 2010).

[Values in bold are statistically different between dry and wet hydrologic conditions based on Mann-Whitney U test. N, number of samples; IQR, interquartile range; $\mathrm{ft}^{3} / \mathrm{s}$; -- none or not applicable; $\mu \mathrm{S} / \mathrm{cm}$, microsiemens per centimeter; <, less than; FNU, formazin nephelometric units; ${ }^{\circ} \mathrm{C}$, degrees Celsius; mg $/ \mathrm{L}$, milligrams per liter; $\mu \mathrm{g} / \mathrm{L}$, micrograms per liter; $\mathrm{NO}_{3}+\mathrm{NO}_{2}$, nitrate plus nitrite, as nitrogen; $\delta \mathrm{D}$, delta deuterium; $\delta^{18} \mathrm{O}$, delta oxygen-18; $\delta^{13} \mathrm{C}$, delta carbon-13; ${ }^{87} \mathrm{Sr} /{ }^{86} \mathrm{Sr}$, strontium-87/strontium-86 isotopic ratio; $\mathrm{CaCO}_{3}$, calcium carbonate; $\mathrm{Mg} / \mathrm{Ca}$, magnesium to calcium molar ratio, $\mathrm{Sr} / \mathrm{Ca} \times 10^{3}$, strontium to calcium molar ratio $\times 1,000 ; \mathrm{SO}_{4} / \mathrm{Cl}$, sulfate to chloride molar ratio; $\mathrm{Mg} / \mathrm{Na}$, magnesium to sodium molar ratio]

\begin{tabular}{|c|c|c|c|c|c|c|c|c|c|c|c|c|c|c|c|c|}
\hline \multirow{4}{*}{$\begin{array}{c}\begin{array}{c}\text { Discharge, } \\
\text { physicochemi- } \\
\text { cal property, } \\
\text { or constituent } \\
\text { concentration }\end{array} \\
\begin{array}{c}\mathrm{N} \text { (unless } \\
\text { otherwise } \\
\text { noted) }\end{array}\end{array}$} & \multirow{3}{*}{ Unit } & \multirow{3}{*}{$\begin{array}{c}\begin{array}{c}\text { Hydro- } \\
\text { logic } \\
\text { condition }\end{array} \\
\begin{array}{c}\text { Dry } \\
\text { period }\end{array} \\
\end{array}$} & \multicolumn{4}{|c|}{ Surface water ${ }^{1,5}$} & \multicolumn{10}{|c|}{ Groundwater wells (Edwards aquifer) 2,5} \\
\hline & & & \multicolumn{2}{|c|}{$\begin{array}{l}\text { Guadalupe at } \\
\text { River Road }\end{array}$} & \multicolumn{2}{|c|}{$\begin{array}{c}\text { Blanco at } \\
\text { Halifax }\end{array}$} & \multicolumn{2}{|c|}{$\begin{array}{l}\text { TSU-West } \\
\text { Campus }\end{array}$} & \multicolumn{2}{|c|}{ Solar } & \multicolumn{2}{|c|}{ Neff } & \multicolumn{2}{|c|}{ Aqua } & \multicolumn{2}{|c|}{ 4D } \\
\hline & & & 7 & -- & 7 & -- & 3 & -- & 6 & -- & 7 & -- & 7 & -- & 6 & -- \\
\hline & & $\begin{array}{c}\text { Wet } \\
\text { period }^{4}\end{array}$ & 11 & -- & 13 & -- & 9 & -- & 8 & -- & 10 & -- & 6 & -- & 9 & -- \\
\hline & & & $\begin{array}{l}\text { median } \\
\text { (N) }\end{array}$ & IOR & $\begin{array}{l}\text { median } \\
\text { (N) }\end{array}$ & IOR & $\begin{array}{l}\text { median } \\
\text { (N) }\end{array}$ & IOR & $\begin{array}{c}\text { median } \\
\text { (N) }\end{array}$ & IOR & $\begin{array}{c}\text { median } \\
\text { (N) }\end{array}$ & IOR & $\begin{array}{c}\text { median } \\
\text { (N) }\end{array}$ & IOR & $\begin{array}{l}\text { median } \\
\text { (N) }\end{array}$ & IOR \\
\hline \multirow[t]{2}{*}{ Discharge } & $\mathrm{ft}^{3} / \mathrm{s}$ & $\begin{array}{l}\text { Dry } \\
\quad \text { period }\end{array}$ & $\begin{array}{c}{ }^{\mathbf{1} 62} \\
(312)\end{array}$ & 15 & $\begin{array}{c}11 \\
(264)\end{array}$ & 9 & -- & -- & -- & -- & -- & -- & -- & -- & -- & -- \\
\hline & & $\begin{array}{l}\text { Wet } \\
\text { period }\end{array}$ & $\begin{array}{l}\mathbf{1} \mathbf{1 2 4} \\
(479) \\
\end{array}$ & 287 & $\begin{array}{c}146 \\
(479)\end{array}$ & 135 & -- & -- & -- & -- & -- & -- & -- & -- & -- & -- \\
\hline \multirow[t]{2}{*}{$\begin{array}{l}\text { Specific } \\
\text { conductance }\end{array}$} & $\mu \mathrm{S} / \mathrm{cm}$ & $\begin{array}{l}\text { Dry } \\
\quad \text { period }\end{array}$ & 393 & 17 & $\begin{array}{c}381 \\
(209)\end{array}$ & 41 & $\begin{array}{c}\mathbf{8 1 0} \\
(227)\end{array}$ & 16 & 536 & 14 & 574 & 4 & 630 & 3 & 574 & 5 \\
\hline & & $\begin{array}{l}\text { Wet } \\
\text { period }\end{array}$ & 436 & 30 & $\begin{array}{c}455 \\
(476)\end{array}$ & 63 & $\begin{array}{c}\mathbf{6 5 6} \\
(448)\end{array}$ & 83 & 548 & 17 & 576 & 6 & 622 & 5 & 575 & 6 \\
\hline \multirow[t]{2}{*}{ Turbidity } & FNU & $\begin{array}{l}\text { Dry } \\
\quad \text { period }\end{array}$ & 6.7 & 1.2 & $\begin{array}{l}6.6 \\
(30)\end{array}$ & 4.7 & 0.3 & 6.2 & $\begin{array}{l}<0.3 \\
(5)\end{array}$ & 0.1 & $<0.3$ & 0.0 & $<0.3$ & 0.1 & $<0.3$ & 0.1 \\
\hline & & $\begin{array}{l}\text { Wet } \\
\text { period }\end{array}$ & 5.8 & 8.1 & $\begin{array}{c}45.5 \\
(380)\end{array}$ & 106 & $<0.3$ & 1.3 & $<0.3$ & 0.5 & $<0.3$ & 0.0 & $<0.3$ & 0.8 & $<0.3$ & 0.0 \\
\hline \multirow[t]{2}{*}{$\begin{array}{r}\text { Dissolved } \\
\text { oxygen }\end{array}$} & $\mathrm{mg} / \mathrm{L}$ & $\begin{array}{l}\text { Dry } \\
\text { period }\end{array}$ & 8.6 & 1.2 & $\begin{array}{c}7.7 \\
(155)\end{array}$ & 0.4 & 5.8 & 0.2 & 7.4 & 1.6 & 5.4 & 0.3 & 4.0 & 2.1 & 7.4 & 0.4 \\
\hline & & $\begin{array}{l}\text { Wet } \\
\text { period }\end{array}$ & 9.2 & 2.4 & $\begin{array}{c}8.9 \\
(479) \\
\end{array}$ & 2.1 & 5.9 & 0.1 & 6.7 & 2.5 & 5.4 & 0.2 & 4.9 & 0.4 & 6.9 & 1.3 \\
\hline \multirow[t]{2}{*}{ Temperature } & ${ }^{\circ} \mathrm{C}$ & $\begin{array}{l}\text { Dry } \\
\text { period }\end{array}$ & 21.5 & 8.7 & $\begin{array}{c}\mathbf{2 7 . 6} \\
(209)\end{array}$ & 8.7 & $\begin{array}{l}22.3 \\
(226)\end{array}$ & 0 & 21.9 & 0.4 & 22.4 & 0.7 & 24.0 & 0.1 & 22.0 & 0.2 \\
\hline & & $\begin{array}{l}\text { Wet } \\
\text { period }\end{array}$ & 19.2 & 11.1 & $\begin{array}{c}\mathbf{2 0 . 7} \\
(478) \\
\end{array}$ & 12.1 & $\begin{array}{c}22.3 \\
(451) \\
\end{array}$ & 0 & 21.9 & 0.2 & 22.2 & 0.3 & 24.0 & 0.3 & 22.0 & 0.4 \\
\hline \multirow[t]{2}{*}{ Calcium } & $\mathrm{mg} / \mathrm{L}$ & $\begin{array}{l}\text { Dry } \\
\text { period }\end{array}$ & 41.0 & 3.5 & 43.5 & 15.5 & 89.0 & 4.5 & 105.5 & 12.0 & 84.5 & 4.3 & 55.5 & 2.3 & 89.9 & 3.1 \\
\hline & & $\begin{array}{l}\text { Wet } \\
\text { period }\end{array}$ & 56.7 & 7.0 & 61.2 & 15.4 & 92.9 & 5.2 & 104.0 & 30.6 & 85.8 & 5.8 & 55.6 & 5.0 & 87.7 & 7.4 \\
\hline \multirow[t]{2}{*}{ Magnesium } & $\mathrm{mg} / \mathrm{L}$ & $\begin{array}{l}\text { Dry } \\
\quad \text { period }\end{array}$ & 18.3 & 1.2 & 19.8 & 1.9 & 16.7 & 0.3 & 3.8 & 0.8 & 19.8 & 1.0 & 31.8 & 0.7 & 16.1 & 0.6 \\
\hline & & $\begin{array}{l}\text { Wet } \\
\text { period }\end{array}$ & 17.2 & 1.4 & 15.5 & 2.7 & 16.8 & 0.6 & 6.4 & 13.4 & 20.3 & 0.7 & 32.5 & 1.4 & 16.6 & 0.9 \\
\hline \multirow[t]{2}{*}{ Alkalinity } & $\begin{array}{c}\mathrm{mg} / \mathrm{L} \text { as } \\
\mathrm{CaCO}_{3}\end{array}$ & $\begin{array}{l}\text { Dry } \\
\quad \text { period }\end{array}$ & 160 & 26 & 156 & 48 & 277 & 26 & 281 & 12 & 277 & 33 & 224 & 28 & 265 & 19 \\
\hline & & $\begin{array}{l}\text { Wet } \\
\text { period }\end{array}$ & 189 & 15 & 194 & 26 & 265 & 19 & 275 & 17 & 280 & 18 & 236 & 12 & 273 & 13 \\
\hline \multirow[t]{2}{*}{ Strontium } & $\mu \mathrm{g} / \mathrm{L}$ & $\begin{array}{l}\text { Dry } \\
\text { period }\end{array}$ & 434 & 33 & 584 & 87 & 476 & 20 & 66 & 13 & 270 & 28 & $\begin{array}{l}42,400 \\
(6)\end{array}$ & 2,400 & 466 & 42 \\
\hline & & $\begin{array}{l}\text { Wet } \\
\text { period }\end{array}$ & 372 & 73 & 307 & 115 & 485 & 13 & 121 & 362 & 252 & 18 & 41,900 & 600 & 500 & 43 \\
\hline \multirow[t]{2}{*}{ Sodium } & $\mathrm{mg} / \mathrm{L}$ & $\begin{array}{l}\text { Dry } \\
\quad \text { period }\end{array}$ & 10.4 & 0.7 & 8.8 & 2.0 & 10.7 & 0.2 & 3.2 & 0.2 & 5.5 & 0.3 & 6.5 & 0.4 & 7.0 & 0.1 \\
\hline & & $\begin{array}{l}\text { Wet } \\
\text { period }\end{array}$ & 9.3 & 1.3 & 7.2 & 1.8 & 10.3 & 0.2 & 3.4 & 0.5 & 5.4 & 0.3 & 6.6 & 0.6 & 6.8 & 0.4 \\
\hline
\end{tabular}




\begin{tabular}{|c|c|c|c|c|c|c|c|c|c|c|c|c|c|c|c|c|}
\hline \multirow{4}{*}{$\begin{array}{c}\text { Discharge, } \\
\text { physicochemi- } \\
\text { cal property, } \\
\text { or constituent } \\
\text { concentration } \\
\mathbf{N} \text { (unless } \\
\text { otherwise } \\
\text { noted) }\end{array}$} & \multicolumn{6}{|c|}{ Groundwater wells (Trinity aquifer) ${ }^{2,5}$} & \multicolumn{10}{|c|}{ Springs $^{1,2,5,6}$} \\
\hline & \multicolumn{2}{|c|}{ Mendez } & \multicolumn{2}{|c|}{ Sac-N-Pac } & \multicolumn{2}{|c|}{$\begin{array}{c}\text { Ruby } \\
\text { Ranch }\end{array}$} & \multicolumn{2}{|c|}{$\begin{array}{c}\text { San Marcos } \\
\text { Springs - } \\
\text { Diversion } \\
\text { Spring orifice }\end{array}$} & \multicolumn{2}{|c|}{$\begin{array}{c}\text { San Marcos } \\
\text { Springs - Deep } \\
\text { Spring orifice }\end{array}$} & \multicolumn{2}{|c|}{$\begin{array}{c}\text { San Marcos } \\
\text { Springs - } \\
\text { Weissmuller } \\
\text { Spring orifice }\end{array}$} & \multicolumn{2}{|c|}{$\begin{array}{l}\text { Comal } \\
\text { Springs }\end{array}$} & \multicolumn{2}{|c|}{$\begin{array}{l}\text { Hueco } \\
\text { Springs }\end{array}$} \\
\hline & 7 & - & 7 & -- & 6 & - & 7 & -- & 7 & -- & 0 & -- & 7 & -- & 7 & -- \\
\hline & 10 & -- & 5 & -- & 3 & -- & 26 & -- & 26 & -- & 11 & -- & 17 & -- & 17 & -- \\
\hline & $\begin{array}{l}\text { median } \\
\text { (N) }\end{array}$ & IQR & $\begin{array}{c}\text { median } \\
\text { (N) }\end{array}$ & IOR & $\begin{array}{l}\text { median } \\
\text { (N) }\end{array}$ & IOR & $\begin{array}{c}\text { median } \\
\text { (N) }\end{array}$ & IOR & $\begin{array}{c}\text { median } \\
\text { (N) }\end{array}$ & IOR & $\begin{array}{l}\text { median } \\
\text { (N) }\end{array}$ & IOR & $\begin{array}{c}\text { median } \\
\text { (N) }\end{array}$ & IOR & $\begin{array}{l}\text { median } \\
\text { (N) }\end{array}$ & IOR \\
\hline \multirow[t]{2}{*}{ Discharge } & -- & -- & -- & -- & -- & -- & $\begin{array}{c}96 \\
(312)\end{array}$ & 9 & $\begin{array}{c}96 \\
(312)\end{array}$ & 9 & $\begin{array}{c}96 \\
(312)\end{array}$ & 9 & $\begin{array}{c}\mathbf{2 6 5} \\
(312)\end{array}$ & 103 & $\begin{array}{c}\mathbf{6 . 3} \\
(312)\end{array}$ & 2.5 \\
\hline & -- & -- & -- & -- & -- & -- & $\begin{array}{c}207 \\
(479)\end{array}$ & 48 & $\begin{array}{c}207 \\
(479) \\
\end{array}$ & 48 & $\begin{array}{c}207 \\
(479) \\
\end{array}$ & 48 & $\begin{array}{c}335 \\
(479) \\
\end{array}$ & 39 & $\begin{array}{c}76 \\
(479) \\
\end{array}$ & 29 \\
\hline \multirow{2}{*}{$\begin{array}{l}\text { Specific } \\
\text { conduc- } \\
\text { tance }\end{array}$} & 458 & 8 & 505 & 43 & 552 & 29 & $\begin{array}{c}\mathbf{6 0 0} \\
(188)\end{array}$ & 8 & $\begin{array}{c}623 \\
(140)\end{array}$ & 7 & -- & -- & 555 & 4 & 573 & 18 \\
\hline & 460 & 3 & 506 & 9 & 564 & 6 & $\begin{array}{c}\mathbf{5 9 3} \\
(405)\end{array}$ & 12 & $\begin{array}{c}611 \\
(396)\end{array}$ & 6 & $\begin{array}{c}595 \\
(183)\end{array}$ & 6 & $\begin{array}{l}559 \\
(18)\end{array}$ & 4 & $\begin{array}{l}595 \\
(18)\end{array}$ & 52 \\
\hline \multirow[t]{2}{*}{ Turbidity } & $<0.3$ & 0.2 & 2.1 & 9.2 & 0.4 & 1.2 & $\begin{array}{l}<0.3 \\
(170)\end{array}$ & 0.00 & $\begin{array}{l}<0.3 \\
(191)\end{array}$ & 0.08 & -- & -- & $<0.3$ & 0.0 & $<0.3$ & 0.8 \\
\hline & $\begin{array}{c}<0.3 \\
(9)\end{array}$ & 0.0 & 0.3 & 2.2 & $<0.3$ & 3.0 & $\begin{array}{l}<0.3 \\
(406) \\
\end{array}$ & 0.01 & $\begin{array}{l}<0.3 \\
(314)\end{array}$ & 0.05 & $\begin{array}{c}0.6 \\
(166) \\
\end{array}$ & 0.2 & $\begin{array}{l}<0.3 \\
(18)\end{array}$ & 0.00 & $\begin{array}{r}6.1 \\
(18) \\
\end{array}$ & 7.7 \\
\hline \multirow[t]{2}{*}{$\begin{array}{r}\text { Dissolved } \\
\text { oxygen }\end{array}$} & $\begin{array}{l}5.4 \\
(6)\end{array}$ & 2.8 & 5.0 & 0.7 & 8.2 & 0.5 & 5.7 & 0.2 & 5.6 & 1.2 & -- & -- & 5.6 & 0.2 & 5.7 & 1.6 \\
\hline & $\begin{array}{l}5.4 \\
(9)\end{array}$ & 0.1 & 5.5 & 2.1 & 8.2 & 0.2 & $\begin{array}{c}4.9 \\
(15)\end{array}$ & 0.3 & $\begin{array}{c}5.7 \\
(15)\end{array}$ & 1.4 & $4.4(9)$ & 0.0 & $\begin{array}{c}5.8 \\
(18)\end{array}$ & 0.2 & $\begin{array}{c}6.1 \\
(18)\end{array}$ & 1.0 \\
\hline \multirow[t]{2}{*}{ Temperature } & 24.4 & 1.5 & 23.4 & 0.5 & 21.5 & 0.2 & $\begin{array}{c}\mathbf{2 1 . 9} \\
(190)\end{array}$ & 0.2 & $\begin{array}{c}\mathbf{2 2 . 3} \\
(149)\end{array}$ & 0.1 & -- & -- & 23.3 & 0.1 & 21.2 & 2.9 \\
\hline & 24.3 & 0.2 & 23.1 & 0.2 & 2.2 & 0.3 & $\begin{array}{c}21.6 \\
(406)\end{array}$ & 0.0 & $\begin{array}{c}\mathbf{2 2 . 1} \\
(398)\end{array}$ & 0.2 & $\begin{array}{c}21.5 \\
(183)\end{array}$ & 0.3 & $\begin{array}{l}23.2 \\
(18)\end{array}$ & 0.1 & $\begin{array}{l}22.0 \\
(18)\end{array}$ & 0.8 \\
\hline \multirow[t]{2}{*}{ Calcium } & 52.5 & 4.7 & 55.5 & 12.4 & 63.9 & 4.6 & 89.9 & 6.2 & 92.1 & 3.9 & -- & -- & 82.8 & 2.0 & 76.8 & 5.8 \\
\hline & 54.5 & 3.2 & 70.3 & 21.2 & 64.3 & 7.2 & 87.8 & 4.1 & 93.5 & 3.2 & 85.6 & 2.1 & 82.2 & 5.0 & 99.5 & 6.8 \\
\hline \multirow[t]{2}{*}{ Magnesium } & 23.2 & 1.2 & 25.6 & 1.6 & 31.1 & 0.9 & 17.0 & 1.1 & 16.4 & 0.6 & - & -- & 16.3 & 1.1 & 18.9 & 1.1 \\
\hline & 23.7 & 0.7 & 18.8 & 6.0 & 31.8 & 3.0 & 18.0 & 0.8 & 16.6 & 0.5 & 18.3 & 0.4 & 15.7 & 0.6 & 10.6 & 3.1 \\
\hline \multirow[t]{2}{*}{ Alkalinity } & 227 & 22 & 243 & 25 & 272 & 18 & 268 & 26 & 270 & 14 & - & - & 243 & 24 & 247 & 40 \\
\hline & 227 & 19 & 256 & 22 & 243 & 35 & 263 & 28 & 269 & 24 & 247 & 20 & 234 & 15 & 263 & 19 \\
\hline \multirow[t]{2}{*}{ Strontium } & 1,280 & 90 & 811 & 960 & 6,245 & 1,850 & 480 & 28 & 507 & 38 & -- & -- & 579 & 34 & 523 & 27 \\
\hline & 1,210 & 60 & 548 & 489 & 5,370 & 1,510 & 514 & 33 & 517 & 17 & 549 & 16 & 572 & 9 & 239 & 157 \\
\hline \multirow[t]{2}{*}{ Sodium } & 4.3 & 0.4 & 4.3 & 0.7 & 6.1 & 0.6 & 9.8 & 0.7 & 12.1 & 2.2 & -- & -- & 10.2 & 0.9 & 11.4 & 0.8 \\
\hline & 4.4 & 0.2 & 4.3 & 0.5 & 6.3 & 0.7 & 9.9 & 0.8 & 12.1 & 0.6 & 11.1 & 0.9 & 10.4 & 0.6 & 8.7 & 1.6 \\
\hline
\end{tabular}


Table 5. Summary statistics for discharge, physicochemical properties, and selected geochemical constituents for surface-water, groundwater, and spring sites sampled during dry and wet hydrologic conditions in the vicinity of San Marcos Springs, south-central Texas (November 2008-December 2010).-Continued

[Values in bold are statistically different between dry and wet hydrologic conditions based on Mann-Whitney U test. N, number of samples; IQR, interquartile range; $\mathrm{ft}^{3} / \mathrm{s}$; -- none or not applicable; $\mu \mathrm{S} / \mathrm{cm}$, microsiemens per centimeter; $<$, less than; FNU, formazin nephelometric units; ${ }^{\circ} \mathrm{C}$, degrees Celsius; $\mathrm{mg} / \mathrm{L}$, milligrams per liter; $\mu \mathrm{g} / \mathrm{L}$, micrograms per liter; $\mathrm{NO}_{3}+\mathrm{NO}_{2}$, nitrate plus nitrite, as nitrogen; $\delta \mathrm{D}$, delta deuterium; $\delta^{18} \mathrm{O}$, delta oxygen-18; $\delta^{13} \mathrm{C}$, delta carbon-13; ${ }^{87} \mathrm{Sr} r{ }^{86} \mathrm{Sr}$, strontium-87/strontium-86 isotopic ratio; $\mathrm{CaCO}_{3}$, calcium carbonate; $\mathrm{Mg} / \mathrm{Ca}$, magnesium to calcium molar ratio, $\mathrm{Sr} / \mathrm{Ca} \times 10^{3}$, strontium to calcium molar ratio $\times 1,000 ; \mathrm{SO}_{4} / \mathrm{Cl}$, sulfate to chloride molar ratio; $\mathrm{Mg} / \mathrm{Na}$, magnesium to sodium molar ratio]

\begin{tabular}{|c|c|c|c|c|c|c|c|c|c|c|c|c|c|c|c|c|}
\hline \multirow{4}{*}{ 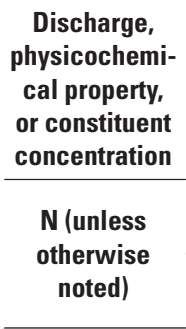 } & \multirow{3}{*}{ Unit } & \multirow{3}{*}{$\begin{array}{c}\begin{array}{c}\text { Hydro- } \\
\text { logic } \\
\text { condition }\end{array} \\
\begin{array}{c}\text { Dry } \\
\text { period }^{3}\end{array} \\
\end{array}$} & \multicolumn{4}{|c|}{ Surface water, } & \multicolumn{10}{|c|}{ Groundwater wells (Edwards aquifer) 2,5} \\
\hline & & & \multicolumn{2}{|c|}{$\begin{array}{l}\text { Guadalupe at } \\
\text { River Road }\end{array}$} & \multicolumn{2}{|c|}{$\begin{array}{l}\text { Blanco at } \\
\text { Halifax }\end{array}$} & \multicolumn{2}{|c|}{$\begin{array}{l}\text { TSU-West } \\
\text { Campus }\end{array}$} & \multicolumn{2}{|c|}{ Solar } & \multicolumn{2}{|c|}{ Neff } & \multicolumn{2}{|c|}{ Aqua } & \multicolumn{2}{|c|}{ 4D } \\
\hline & & & 7 & -- & 7 & -- & 3 & -- & 6 & -- & 7 & -- & 7 & -- & 6 & -- \\
\hline & & $\begin{array}{c}\text { Wet } \\
\text { period }^{4}\end{array}$ & 11 & -- & 13 & -- & 9 & -- & 8 & -- & 10 & -- & 6 & -- & 9 & -- \\
\hline & & & $\begin{array}{l}\text { median } \\
\text { (N) }\end{array}$ & IOR & $\begin{array}{l}\text { median } \\
\text { (N) }\end{array}$ & IOR & $\begin{array}{l}\text { median } \\
\text { (N) }\end{array}$ & IOR & $\begin{array}{l}\text { median } \\
\text { (N) }\end{array}$ & IOR & $\begin{array}{l}\text { median } \\
\text { (N) }\end{array}$ & IOR & $\begin{array}{l}\text { median } \\
\text { (N) }\end{array}$ & IOR & $\begin{array}{l}\text { median } \\
\text { (N) }\end{array}$ & IOR \\
\hline \multirow[t]{2}{*}{ Chloride } & $\mathrm{mg} / \mathrm{L}$ & $\begin{array}{l}\text { Dry } \\
\quad \text { period }\end{array}$ & 16.1 & 0.4 & 14.0 & 2.7 & 18.5 & 0.7 & 3.1 & 0.1 & 9.8 & 0.2 & 10.1 & 0.1 & 12.6 & 0.3 \\
\hline & & $\begin{array}{l}\text { Wet } \\
\text { period }\end{array}$ & 15.9 & 0.9 & 13.9 & 2.9 & 18.5 & 0.9 & 3.9 & 2.3 & 10.3 & 0.6 & 10.4 & 0.7 & 12.7 & 0.6 \\
\hline \multirow[t]{2}{*}{ Sulfate } & $\mathrm{mg} / \mathrm{L}$ & $\begin{array}{l}\text { Dry } \\
\text { period }\end{array}$ & 24.1 & 3.5 & 41.3 & 7.7 & 27.1 & 1.0 & 4.3 & 0.2 & 17.6 & 0.4 & 91.1 & 0.7 & 17.3 & 0.4 \\
\hline & & $\begin{array}{l}\text { Wet } \\
\text { period }\end{array}$ & 22.1 & 1.8 & 28.6 & 10.3 & 24.8 & 0.8 & 5.8 & 7.1 & 16.8 & 1.2 & 86.4 & 4.9 & 16.4 & 0.8 \\
\hline \multirow[t]{2}{*}{ Bromide } & $\mathrm{mg} / \mathrm{L}$ & $\begin{array}{l}\text { Dry } \\
\quad \text { period }\end{array}$ & 0.12 & 0.00 & 0.07 & 0.07 & 0.11 & 0.02 & 0.05 & 0.01 & 0.06 & 0.01 & 0.05 & 0.01 & 0.06 & 0.04 \\
\hline & & $\begin{array}{l}\text { Wet } \\
\text { period }\end{array}$ & 0.10 & 0.01 & 0.07 & 0.02 & 0.11 & 0.01 & 0.05 & 0.01 & 0.07 & 0.01 & 0.06 & 0.00 & 0.07 & 0.01 \\
\hline \multirow[t]{2}{*}{ Boron } & $\mu \mathrm{g} / \mathrm{L}$ & $\begin{array}{l}\text { Dry } \\
\quad \text { period }\end{array}$ & 74.0 & 5.0 & 62.0 & 29.0 & 54.0 & 8.0 & 20.5 & 2.0 & 34.0 & 2.0 & $\begin{array}{l}62.0 \\
(6)\end{array}$ & 6.0 & 43.0 & 4.0 \\
\hline & & $\begin{array}{l}\text { Wet } \\
\text { period }\end{array}$ & 61.0 & 7.0 & 48.0 & 8.0 & 52.0 & 2.0 & 20.5 & 6.5 & 34.5 & 3.0 & 62.0 & 1.0 & 43.0 & 3.0 \\
\hline \multirow[t]{2}{*}{ Fluoride } & $\mathrm{mg} / \mathrm{L}$ & $\begin{array}{l}\text { Dry } \\
\quad \text { period }\end{array}$ & 0.24 & 0.03 & 0.23 & 0.02 & 0.22 & 0.06 & 0.08 & 0.03 & 0.18 & 0.04 & 2.77 & 0.15 & 0.18 & 0.03 \\
\hline & & $\begin{array}{l}\text { Wet } \\
\text { period }\end{array}$ & 0.21 & 0.03 & 0.18 & 0.05 & 0.22 & 0.02 & 0.16 & 0.19 & $0.19(9)$ & 0.02 & 2.78 & 0.22 & 0.19 & 0.02 \\
\hline \multirow[t]{2}{*}{ Potassium } & $\mathrm{mg} / \mathrm{L}$ & $\begin{array}{l}\text { Dry } \\
\quad \text { period }\end{array}$ & 2.1 & 0.1 & 1.5 & 0.4 & 1.3 & 0.1 & 0.6 & 0.0 & 0.8 & 0.0 & 1.4 & 0.1 & 1.1 & 0.1 \\
\hline & & $\begin{array}{l}\text { Wet } \\
\text { period }\end{array}$ & 1.7 & 0.3 & 1.3 & 0.4 & 1.3 & 0.0 & 0.7 & 0.1 & 0.8 & 0.1 & 1.4 & 0.1 & 1.0 & 0.1 \\
\hline \multirow[t]{2}{*}{ Silica } & $\mathrm{mg} / \mathrm{L}$ & $\begin{array}{l}\text { Dry } \\
\quad \text { period }\end{array}$ & 11.8 & 2.2 & 8.2 & 14.9 & 12.1 & 0.4 & 11.4 & 0.4 & 10.8 & 1.1 & 11.4 & 0.7 & 11.6 & 0.7 \\
\hline & & $\begin{array}{l}\text { Wet } \\
\text { period }\end{array}$ & 9.9 & 1.4 & 9.9 & 1.8 & 12.0 & 0.5 & 11.4 & 0.8 & 10.6 & 0.6 & 11.3 & 0.5 & 11.6 & 0.4 \\
\hline \multirow[t]{2}{*}{$\mathrm{NO}_{3}+\mathrm{NO}_{2}$} & $\mathrm{mg} / \mathrm{L}$ & $\begin{array}{l}\text { Dry } \\
\text { period }\end{array}$ & $\begin{array}{c}0.045 \\
(6)\end{array}$ & 0.0 & 0.000 & 0.020 & 1.50 & 0.01 & 2.43 & 0.03 & 0.89 & 0.02 & 0.00 & 0.00 & 1.54 & 0.02 \\
\hline & & $\begin{array}{l}\text { Wet } \\
\text { period }\end{array}$ & 0.32 & 0.46 & 0.45 & 0.48 & 1.64 & 0.07 & 1.99 & 0.94 & 0.86 & 0.03 & 0.00 & 0.00 & 1.50 & 0.09 \\
\hline \multirow[t]{2}{*}{${ }^{87} \mathrm{Sr} /{ }^{86} \mathrm{Sr}$} & -- & $\begin{array}{l}\text { Dry } \\
\text { period }\end{array}$ & 0.70783 & 0.00004 & 0.70783 & 0.00004 & 0.70792 & 0.0000 & 0.708600 & 0.00004 & 40.70787 & 0.00002 & 0.70770 & 0.00003 & $0.70779 c$ & 0.00002 \\
\hline & & $\begin{array}{l}\text { Wet } \\
\text { period }\end{array}$ & 0.70787 & 0.00003 & 0.70791 & 0.00010 & 0.70792 & 0.00002 & 0.708080 & 0.00066 & 60.70789 & 0.00003 & 0.70774 & 0.00004 & $0.70777 \mathrm{C}$ & 0.00003 \\
\hline \multirow[t]{2}{*}{$\delta \mathrm{D}$} & per mil $(\%)$ & $\begin{array}{l}\text { Dry } \\
\quad \text { period }\end{array}$ & -9.3 & 1.6 & -12.0 & 18.1 & -23.6 & 1.0 & -26.9 & 0.6 & -22.6 & 1.0 & -21.1 & 0.6 & -22.9 & 1.0 \\
\hline & & $\begin{array}{l}\text { Wet } \\
\text { period }\end{array}$ & -16.1 & 3.5 & -23.9 & 3.4 & -23.1 & 0.7 & -25.5 & 1.4 & -23.4 & 1.2 & -21.2 & 0.8 & -22.7 & 0.3 \\
\hline
\end{tabular}




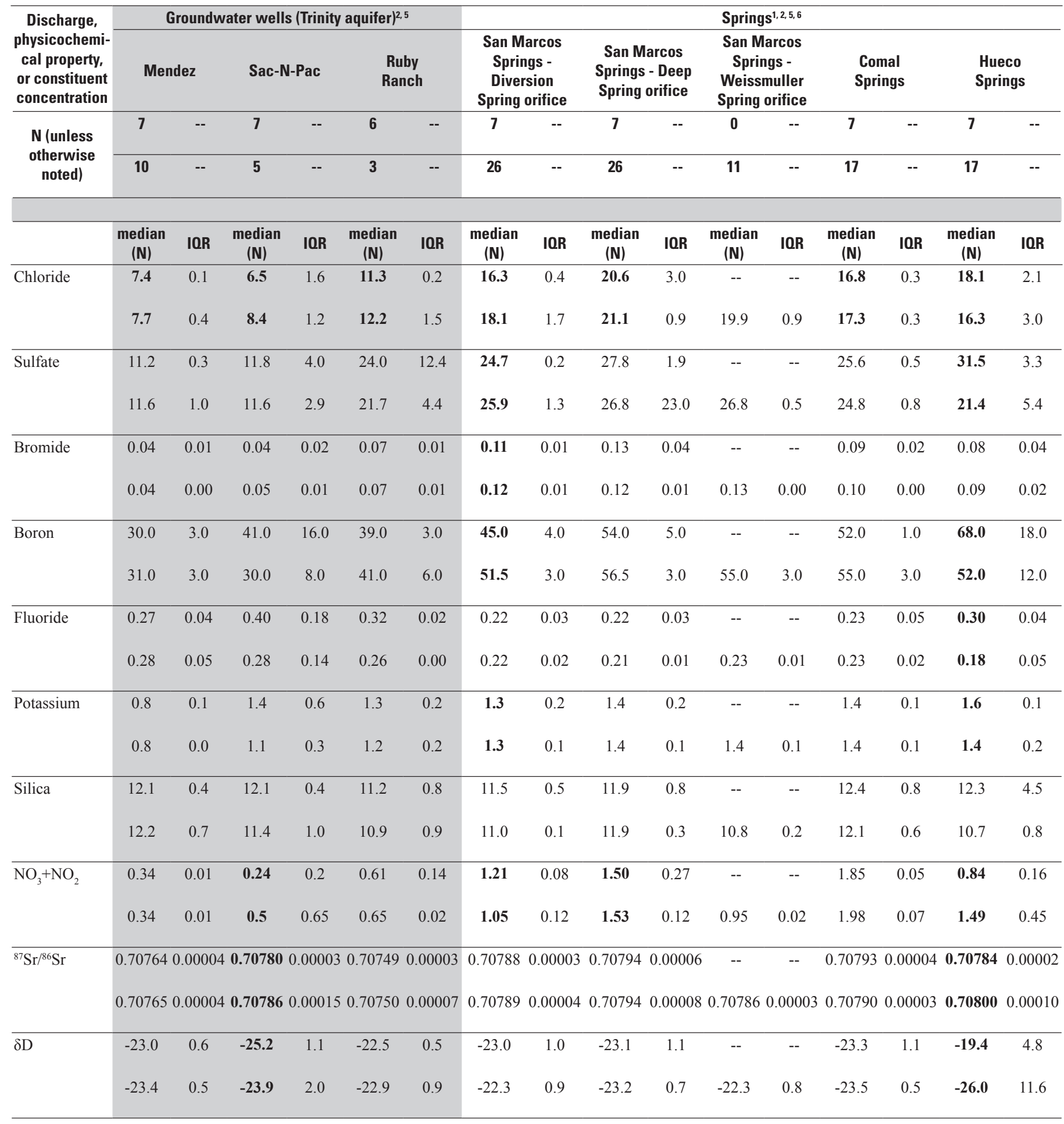


Table 5. Summary statistics for discharge, physícochemical propertíes, and selected geochemical constituents for surface-water, groundwater, and spring sites sampled during dry and wet hydrologic conditions in the vicinity of San Marcos Springs, south-central Texas (November 2008-December 2010).-Continued

[Values in bold are statistically different between dry and wet hydrologic conditions based on Mann-Whitney U test. N, number of samples; IQR, interquartile range; $\mathrm{ft}^{3} / \mathrm{s} ;$-- none or not applicable; $\mu \mathrm{S} / \mathrm{cm}$, microsiemens per centimeter; $<$, less than; $\mathrm{FNU}$, formazin nephelometric units; ${ }^{\circ} \mathrm{C}$, degrees Celsius; $\mathrm{mg} / \mathrm{L}$, milligrams per liter; $\mu \mathrm{g} / \mathrm{L}$, micrograms per liter; $\mathrm{NO}_{3}+\mathrm{NO}_{2}$, nitrate plus nitrite, as nitrogen; $\delta \mathrm{D}$, delta deuterium; $\delta^{18} \mathrm{O}$, delta oxygen-18; $\delta^{13} \mathrm{C}$, delta carbon-13; ${ }^{87} \mathrm{Sr} r{ }^{86} \mathrm{Sr}$, strontium-87/strontium-86 isotopic ratio; $\mathrm{CaCO}_{3}$, calcium carbonate; $\mathrm{Mg} / \mathrm{Ca}$, magnesium to calcium molar ratio, $\mathrm{Sr} / \mathrm{Ca} \times 10^{3}$, strontium to calcium molar ratio $\times 1,000 ; \mathrm{SO}_{4} / \mathrm{Cl}$, sulfate to chloride molar ratio; $\mathrm{Mg} / \mathrm{Na}$, magnesium to sodium molar ratio]

\begin{tabular}{|c|c|c|c|c|c|c|c|c|c|c|c|c|c|c|c|c|}
\hline \multirow{4}{*}{$\begin{array}{c}\begin{array}{c}\text { Discharge, } \\
\text { physicochemi- } \\
\text { cal property, } \\
\text { or constituent } \\
\text { concentration }\end{array} \\
\begin{array}{c}\mathrm{N} \text { (unless } \\
\text { otherwise } \\
\text { noted) }\end{array}\end{array}$} & \multirow{3}{*}{ Unit } & \multirow{3}{*}{$\begin{array}{c}\begin{array}{c}\text { Hydro- } \\
\text { logic } \\
\text { condition }\end{array} \\
\begin{array}{c}\text { Dry } \\
\text { period }\end{array} \\
\end{array}$} & \multicolumn{4}{|c|}{ Surface water ${ }^{1,5}$} & \multicolumn{10}{|c|}{ Groundwater wells (Edwards aquifer) 2, } \\
\hline & & & \multicolumn{2}{|c|}{$\begin{array}{l}\text { Guadalupe at } \\
\text { River Road }\end{array}$} & \multicolumn{2}{|c|}{$\begin{array}{c}\text { Blanco at } \\
\text { Halifax }\end{array}$} & \multicolumn{2}{|c|}{$\begin{array}{l}\text { TSU-West } \\
\text { Campus }\end{array}$} & \multicolumn{2}{|c|}{ Solar } & \multicolumn{2}{|c|}{ Neff } & \multicolumn{2}{|c|}{ Aqua } & \multicolumn{2}{|c|}{ 4D } \\
\hline & & & 7 & -- & 7 & -- & 3 & -- & 6 & -- & 7 & -- & 7 & -- & 6 & -- \\
\hline & & $\begin{array}{c}\text { Wet } \\
\text { period }^{4}\end{array}$ & 11 & -- & 13 & -- & 9 & -- & 8 & -- & 10 & -- & 6 & -- & 9 & -- \\
\hline & & & $\begin{array}{l}\text { median } \\
\text { (N) }\end{array}$ & IOR & $\begin{array}{l}\text { median } \\
\text { (N) }\end{array}$ & IOR & $\begin{array}{l}\text { median } \\
\text { (N) }\end{array}$ & IOR & $\begin{array}{c}\text { median } \\
\text { (N) }\end{array}$ & IOR & $\begin{array}{l}\text { median } \\
\text { (N) }\end{array}$ & IOR & $\begin{array}{c}\text { median } \\
\text { (N) }\end{array}$ & IOR & $\begin{array}{l}\text { median } \\
\text { (N) }\end{array}$ & IOR \\
\hline \multirow[t]{2}{*}{$\delta^{18} \mathrm{O}$} & per mil (\%o) & $\begin{array}{l}\text { Dry } \\
\quad \text { period }\end{array}$ & -1.12 & 0.24 & -2.01 & 4.65 & -4.23 & 0.09 & -4.94 & 0.06 & -4.14 & 0.05 & -3.73 & 0.02 & -4.15 & 0.06 \\
\hline & & $\begin{array}{l}\text { Wet } \\
\text { period }\end{array}$ & -2.61 & 0.42 & -4.25 & 0.62 & -4.24 & 0.06 & -4.75 & 0.17 & -4.25 & 0.09 & -3.76 & 0.05 & -4.16 & 0.08 \\
\hline \multirow[t]{2}{*}{$\delta^{13} \mathrm{C}$} & per mil (\%o) & $\begin{array}{l}\text { Dry } \\
\quad \text { period }\end{array}$ & -5.51 & 0.51 & -3.96 & 1.24 & -8.96 & 0.62 & -11.57 & 0.71 & -8.96 & 1.11 & -3.38 & 0.76 & -9.14 & 0.10 \\
\hline & & $\begin{array}{l}\text { Wet } \\
\text { period }\end{array}$ & -8.57 & 1.42 & -8.31 & 2.11 & -9.48 & 0.12 & -12.13 & 3.95 & $\begin{array}{l}-9.44 \\
(7)\end{array}$ & 0.33 & -3.98 & 0.11 & -9.19 & 0.35 \\
\hline \multirow[t]{2}{*}{$\mathrm{Mg} / \mathrm{Ca}$} & -- & $\begin{array}{l}\text { Dry } \\
\quad \text { period }\end{array}$ & 0.747 & 0.051 & 0.687 & 0.548 & 0.309 & 0.020 & 0.058 & 0.009 & 0.381 & 0.026 & 0.940 & 0.078 & 0.297 & 0.011 \\
\hline & & $\begin{array}{l}\text { Wet } \\
\text { period }\end{array}$ & 0.502 & 0.075 & 0.418 & 0.127 & 0.297 & 0.003 & 0.101 & 0.613 & 0.393 & 0.033 & 0.955 & 0.037 & 0.308 & 0.023 \\
\hline \multirow[t]{2}{*}{$\mathrm{Sr} / \mathrm{Ca} \times 10^{3}$} & -- & $\begin{array}{l}\text { Dry } \\
\text { period }\end{array}$ & 4.80 & 0.46 & 5.85 & 0.55 & 2.38 & 0.15 & 0.27 & 0.03 & 1.47 & 0.12 & $\begin{array}{l}351 \\
(6)\end{array}$ & 30.5 & 2.36 & 0.22 \\
\hline & & $\begin{array}{l}\text { Wet } \\
\text { period }\end{array}$ & 3.02 & 0.38 & 2.28 & 1.61 & 2.33 & 0.25 & 0.53 & 2.29 & 1.36 & 0.15 & 350 & 18.0 & 2.68 & 0.44 \\
\hline \multirow[t]{2}{*}{$\mathrm{SO}_{4} / \mathrm{Cl}$} & -- & $\begin{array}{l}\text { Dry } \\
\text { period }\end{array}$ & 0.56 & 0.07 & 1.02 & 0.18 & 0.52 & 0.02 & 0.52 & 0.03 & 0.67 & 0.01 & 3.31 & 0.06 & 0.51 & 0.01 \\
\hline & & $\begin{array}{l}\text { Wet } \\
\text { period }\end{array}$ & 0.54 & 0.09 & 0.70 & 0.06 & 0.49 & 0.03 & 0.58 & 0.23 & 0.60 & 0.06 & 3.03 & 0.16 & 0.47 & 0.04 \\
\hline \multirow[t]{2}{*}{$\mathrm{Mg} / \mathrm{Na}$} & -- & $\begin{array}{l}\text { Dry } \\
\text { period }\end{array}$ & 1.66 & 0.11 & 2.12 & 0.15 & 1.48 & 0.06 & 1.04 & 0.20 & 3.44 & 0.27 & 4.65 & 0.23 & 2.20 & 0.11 \\
\hline & & $\begin{array}{l}\text { Wet } \\
\text { period }\end{array}$ & 1.83 & 0.28 & 2.03 & 0.13 & 1.56 & 0.06 & 1.78 & 3.27 & 3.55 & 0.28 & 4.65 & 0.12 & 2.32 & 0.17 \\
\hline \multirow{2}{*}{$\begin{array}{l}\text { Calcite } \\
\text { saturation } \\
\text { index }\end{array}$} & -- & $\begin{array}{l}\text { Dry } \\
\quad \text { period }\end{array}$ & 0.73 & 0.15 & 0.73 & 0.23 & -0.13 & 0.12 & -0.05 & 0.43 & 0.04 & 0.39 & 0.08 & 0.40 & 0.21 & 0.34 \\
\hline & & $\begin{array}{l}\text { Wet } \\
\text { period }\end{array}$ & 0.65 & 0.15 & 0.72 & 0.40 & 0.09 & 0.08 & 0.06 & 0.12 & 0.10 & 0.08 & 0.21 & 0.05 & 0.15 & 0.19 \\
\hline \multirow{2}{*}{$\begin{array}{l}\text { Dolomite } \\
\text { saturation } \\
\text { index }\end{array}$} & -- & $\begin{array}{l}\text { Dry } \\
\quad \text { period }\end{array}$ & 1.42 & 0.40 & 1.54 & 0.61 & -0.65 & 0.28 & -1.27 & 0.72 & -0.24 & 0.75 & 0.22 & 0.79 & -0.01 & 0.68 \\
\hline & & $\begin{array}{l}\text { Wet } \\
\text { period }\end{array}$ & 0.96 & 0.33 & 0.94 & 0.45 & -0.20 & 0.16 & -0.51 & 1.07 & -0.16 & 0.18 & 0.53 & 0.11 & -0.07 & 0.42 \\
\hline \multirow{2}{*}{$\begin{array}{l}\text { Gypsum } \\
\text { saturation } \\
\text { index }\end{array}$} & -- & $\begin{array}{l}\text { Dry } \\
\quad \text { period }\end{array}$ & -2.38 & 0.07 & -2.22 & 0.16 & -2.09 & 0.01 & -2.78 & 0.02 & -2.28 & 0.02 & -1.79 & 0.31 & -2.26 & 0.02 \\
\hline & & $\begin{array}{l}\text { Wet } \\
\text { period }\end{array}$ & -2.30 & 0.08 & -2.18 & 0.19 & -2.12 & 0.03 & -2.66 & 2.19 & -2.30 & 0.02 & -1.81 & 0.05 & -2.30 & 0.02 \\
\hline
\end{tabular}

${ }^{1}$ Stream discharge for Blanco at Halifax, spring discharge for San Marcos Springs, and selected physicochemical data for Blanco at Halifax and San Marcos Springs measured continuously at 15 -minute intervals; summary statistics based on daily mean values. Stream discharge for Guadalupe at River Road (gage height/discharge not measured) reflects values measured at upstream Guadalupe at Sattler site.

${ }^{2}$ Physicochemical properties for groundwater wells, Hueco Springs, and Comal Springs measured at time of routine sample collection.

${ }^{3}$ Dry period: November 1, 2008, through September 8, 2009. 


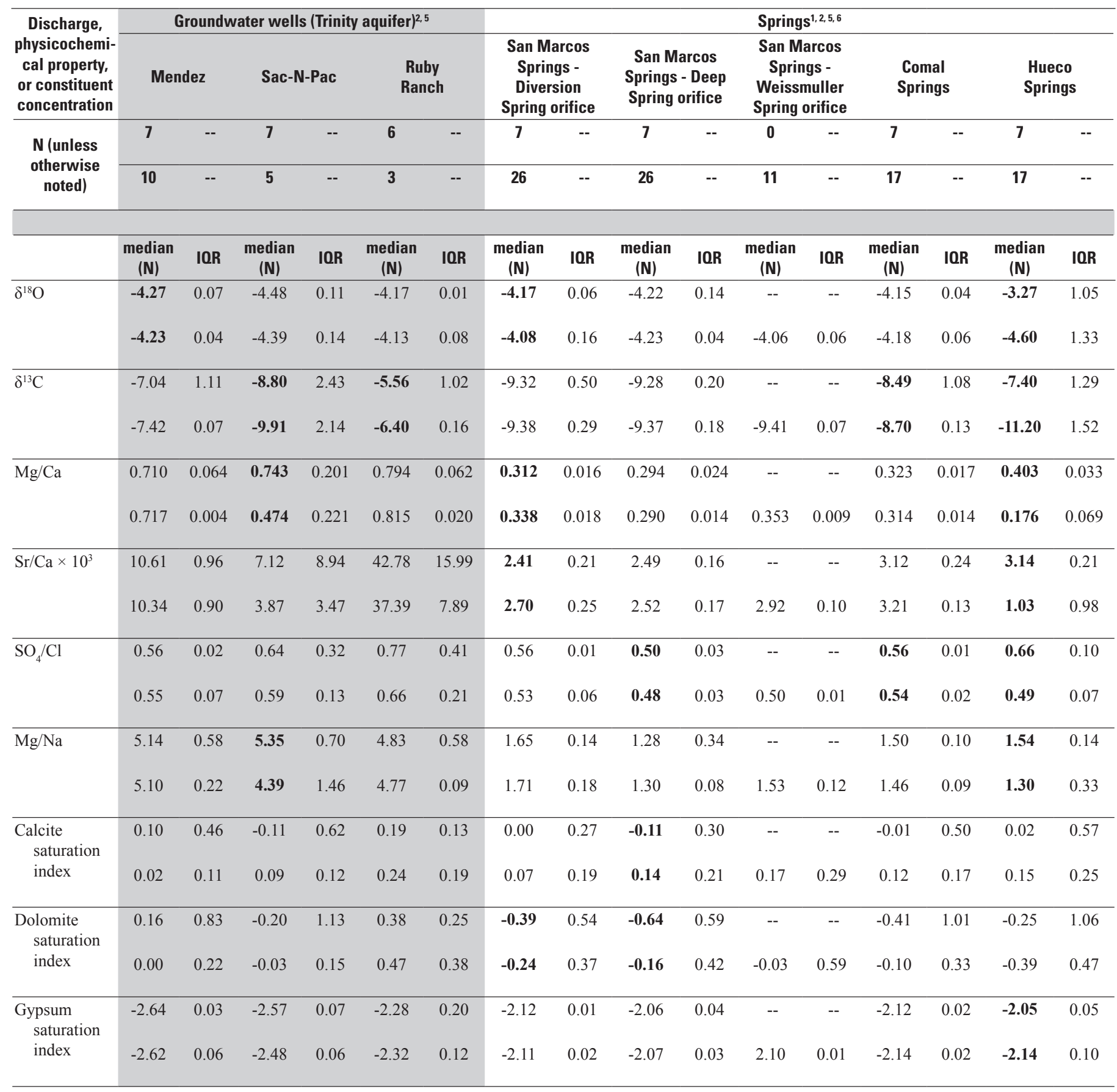

${ }^{4}$ Wet period: September 9, 2009, through December 31, 2010.

${ }^{5}$ Short names are used here; see table 1 for complete U.S. Geological Survey station names and numbers.

${ }^{6}$ Discharge data for San Marcos, Comal, and Hueco Springs (complexes); physicochemical and geochemical data for individual spring orifices Deep Spring, Diversion Spring, Weissmuller Spring, Comal Spring 1, and Hueco Spring A. 

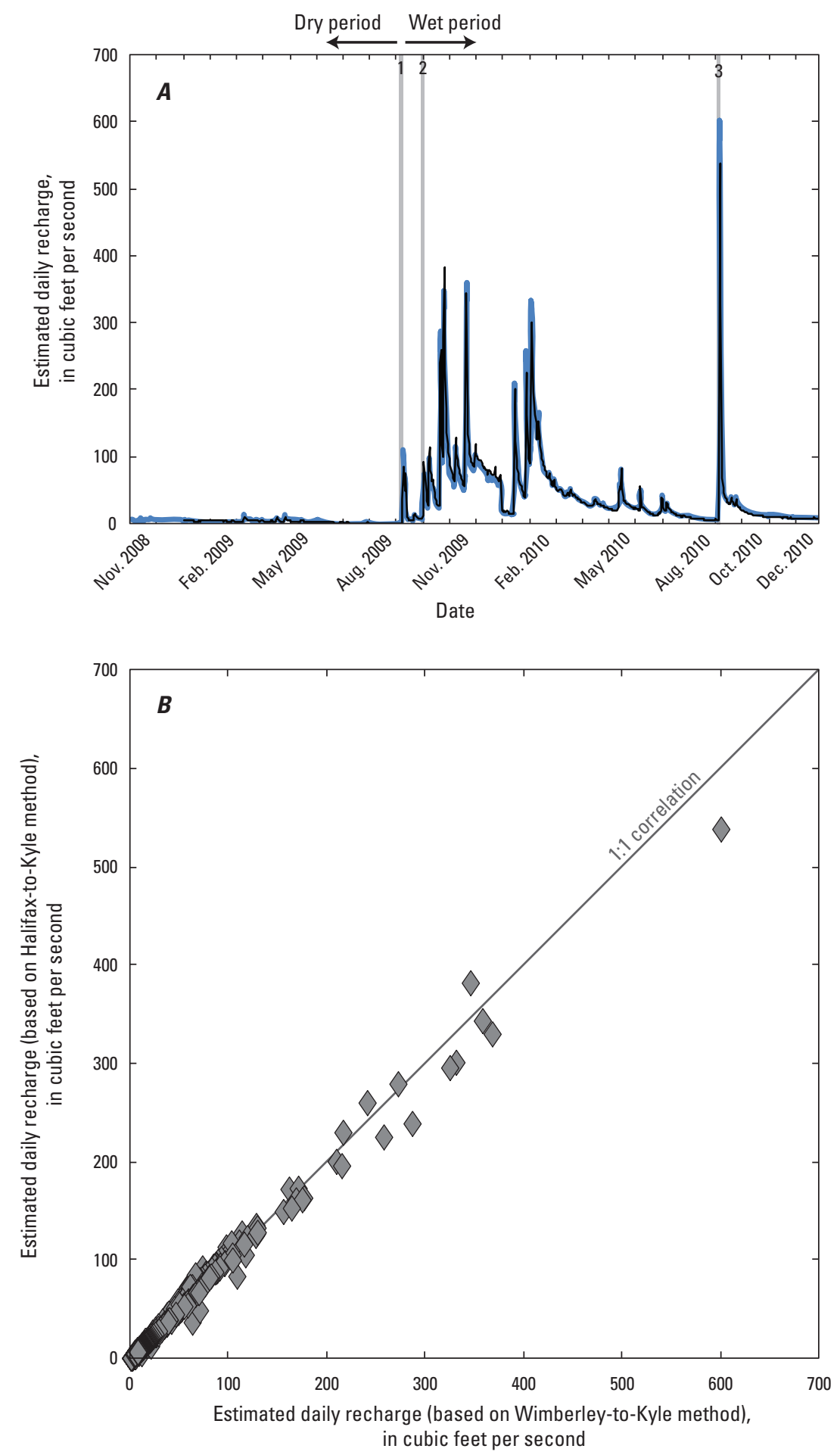

EXPLANATION

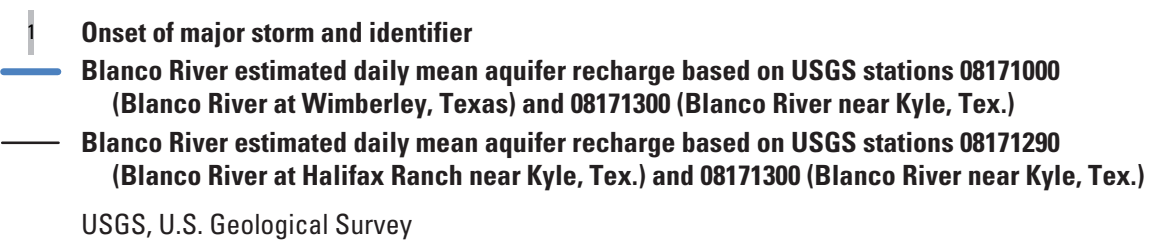

Figure 10. Estimated daily recharge to the Edwards aquifer from the Blanco River, south-central Texas, computed from two pairs of U.S. Geological Survey streamflow-gaging stations. A, Time series (November 2008-December 2010). B, Relation between estimated recharge from the two station pairs. 


\section{Geochemistry of San Marcos Springs and Nearby Hydrologic Features}

\section{Hydrologic and Physicochemical Data}

Continuous measurements for discharge and physicochemical properties were recorded at selected stream and spring sites. Continuous measurement of water-table altitude and some physicochemical properties were recorded at selected groundwater sites. Summary statistics for discharge and (or) physicochemical properties from stream, well, and spring sites are shown in table 5.

\section{Surface Water}

Continuous discharge was recorded at Blanco at Halifax beginning in December 2008, and physicochemical properties were recorded beginning in February 2009; daily mean values for discharge, selected physicochemical properties, and rainfall through December 2010 are shown in figure 11. Discharge at Blanco at Halifax ranged from a low of $2.3 \mathrm{ft}^{3} / \mathrm{s}$ on July 28 and 29, 2009, to an estimated high of $3,620 \mathrm{ft}^{3} / \mathrm{s}$ on September 8, 2010, in response to storm 3 . Water temperature fluctuated seasonally between 4.5 and 31.9 degrees Celsius $\left({ }^{\circ} \mathrm{C}\right)$ with warmer temperatures occurring in summer and colder temperatures occurring in winter; some sudden decreases in temperature were associated with rain events. Specific conductance ranged from 258 to 515 $\mu \mathrm{S} / \mathrm{cm}$; large and rapid decreases in specific conductance occurred with increased stream discharge in response to rain events. Turbidity values of generally less than 100 FNU were punctuated with sudden large increases, as large as 2,890 FNU, in response to rain events. Variations in turbidity were small during the dry period. During the wet period, daily mean turbidity values increased from less than $100 \mathrm{FNU}$ in mid-July 2010 to 700 FNU in early September 2010 then returned to less than 100 FNU by late September 2010; the cause of this sustained increase in turbidity occurring over several months is unknown and does not correlate with stream discharge. Dissolved oxygen concentrations varied seasonally between 6.7 and $12.9 \mathrm{mg} / \mathrm{L}$ and inversely with temperature, with lower concentrations occurring in the summer and higher concentrations occurring in the winter. Discharge, specific conductance, turbidity, and concentrations of dissolved oxygen were significantly higher during the wet period than during the dry period, and water temperature was lower (table 5). Discharge and all measured physicochemical properties were more variable in the wet period relative to the dry period and had larger interquartile ranges (table 5).

Physicochemical properties measured for grab samples from the Guadalupe at River Road site are shown in figures 12 and 13. Physicochemical properties measured at the Guadalupe at River Road site were mostly similar to those measured continuously at the Blanco at Halifax gage, both with respect to changes from the dry and wet periods (table 5), as well as those measured throughout the study (fig. 12). The median water temperature at the Guadalupe at River Road site during the dry period was cooler than at the Blanco at Halifax gage (table 5). In particular, during summer 2010, water temperatures at Guadalupe at River Road were cooler than those at Blanco at Halifax, which might have resulted from increased releases of colder water into the Guadalupe River from Canyon Lake. Similar to the Blanco at Halifax, median specific conductance values for the Guadalupe at River Road were higher during the wet period than during the dry period (table 5). Turbidity values at Guadalupe at River Road were similar between the dry and wet periods, unlike at Blanco at Halifax, although turbidity at Guadalupe at River Road was not measured in response to storms. Turbidity and dissolved oxygen concentrations at the stream sites were generally higher than at the groundwater well and spring sites, whereas specific conductance was lower at stream sites (table 5).

Continuous discharge was measured by the USGS for other stream sites in the study area, including additional sites on the Guadalupe River, Cibolo Creek, and Dry Comal Creek (U.S. Geological Survey, 2011). Physicochemical properties measured for grab samples from other stream sites (Blanco near Kyle, Cibolo Creek, Sink Creek, and Purgatory Creek) (fig. 1; table 1) collected during storms 1-3 are shown on figures 12 and 13. In response to storms 1-3, physicochemical properties at all sites where measured were characterized by relatively low specific conductance and relatively high turbidity values compared to routine samples.

\section{Groundwater}

Water-table altitude and physicochemical properties (water temperature and specific conductance) were monitored continuously at hourly intervals at two wells in the vicinity of San Marcos Springs: Tipps and TSU-West Campus (fig. 14). Water-table altitude at both wells was relatively stable during the dry period and increased similarly at both wells during the wet period. The lowest water-table altitude occurred at the end of the dry period, and the highest values occurred in February 2010 at both wells; the total variation was 6.42 and $4.88 \mathrm{ft}$ at the Tipps and TSU-West Campus wells, respectively. At both wells, the water-table altitude gradually decreased after peak values in February 2010 (fig. 14).

Specific conductance at the Tipps well covered a large range (591-984 $\mu \mathrm{S} / \mathrm{cm}$ ) and increased through much of the dry period, with the highest values occurring at the end of the dry period. Two rapid increases in specific conductance occurred during the dry period in July and September 2009; these increases had no discernible relation with water level or hydrologic conditions. Specific conductance dropped rapidly with the onset of the wet period. At the TSU-West Campus well, specific conductance ranged from 617 to 834 $\mu \mathrm{S} / \mathrm{cm}$; the highest values occurred during the later part of the dry period, with specific conductance generally decreasing through the wet period. Specific conductance was significantly higher at both wells during the dry period than during the 


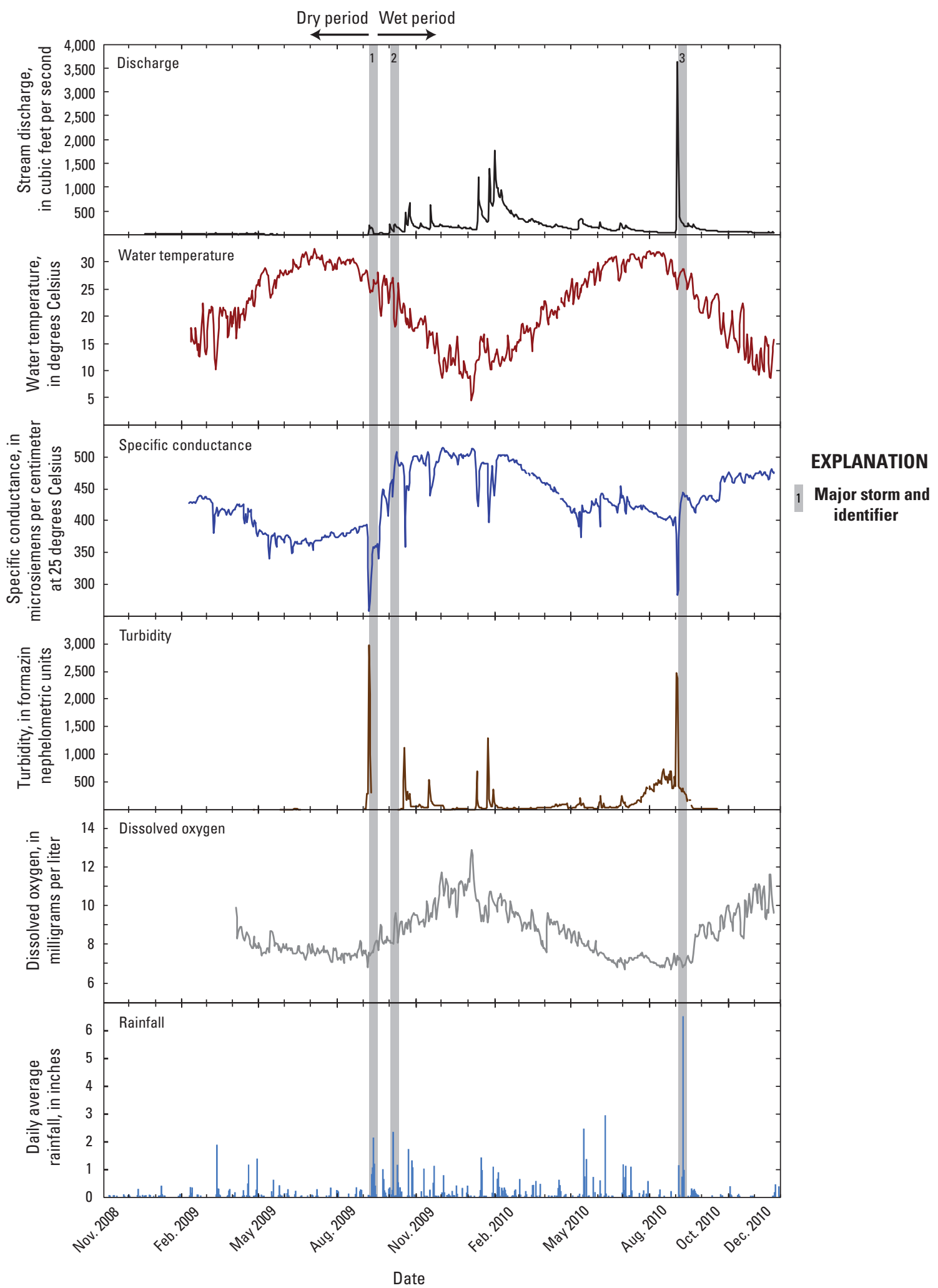

Figure 11. Times series (November 2008-December 2010) of stream discharge, water temperature, specific conductance, turbidity, and dissolved oxygen (daily means) for U.S. Geological Survey station 08171290 (Blanco River at Halifax Ranch near Kyle, Texas), and daily average rainfall in the vicinity of San Marcos Springs, south-central Texas (mean for National Weather Service Cooperative Stations 411429, 412585, 416276, 417983, 418544, and 419815, National Oceanic and Atmospheric Administration, 2011). 
Dry period Wet period
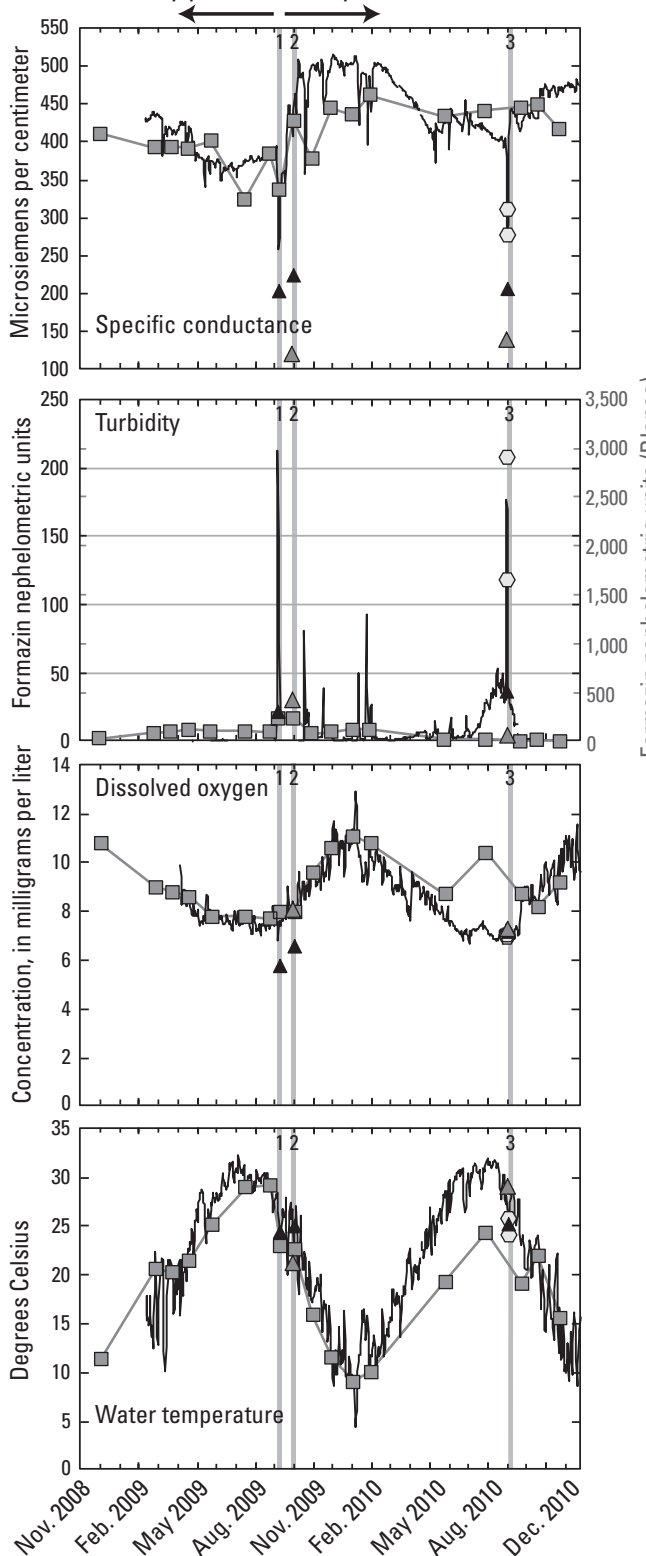

Dry period Wet period
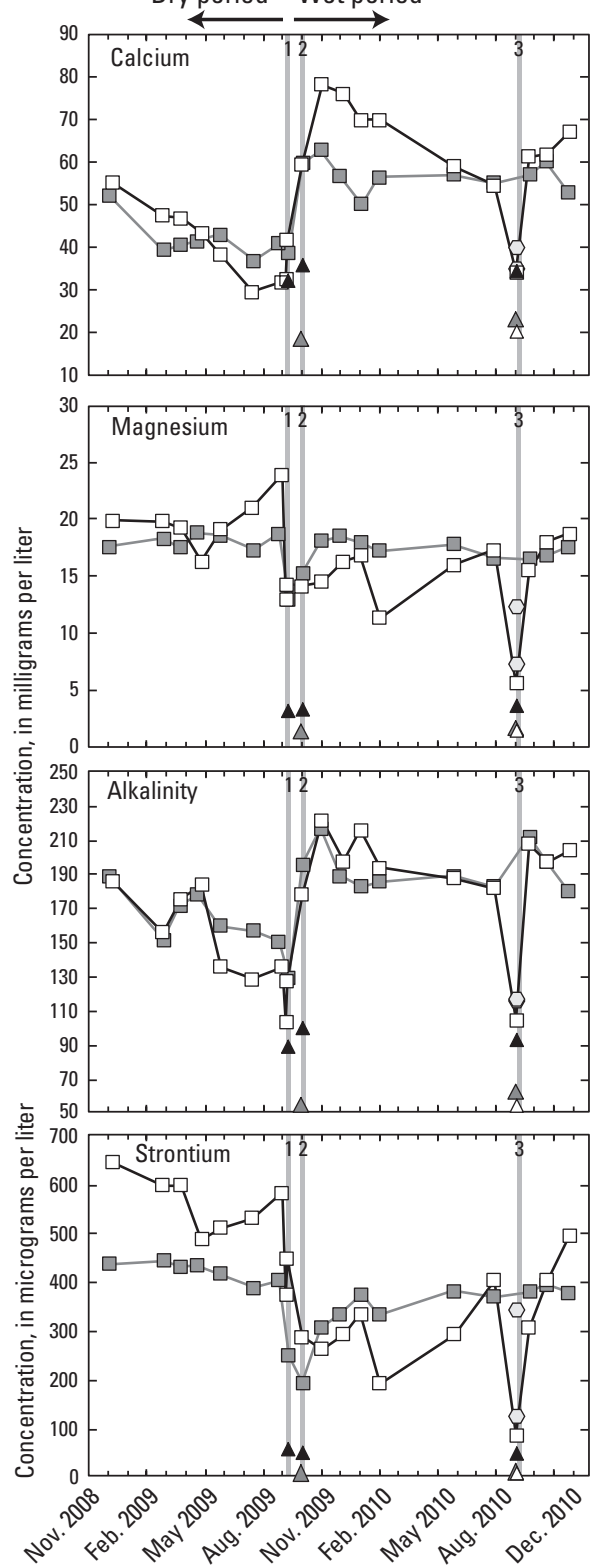

Dry period Wet period
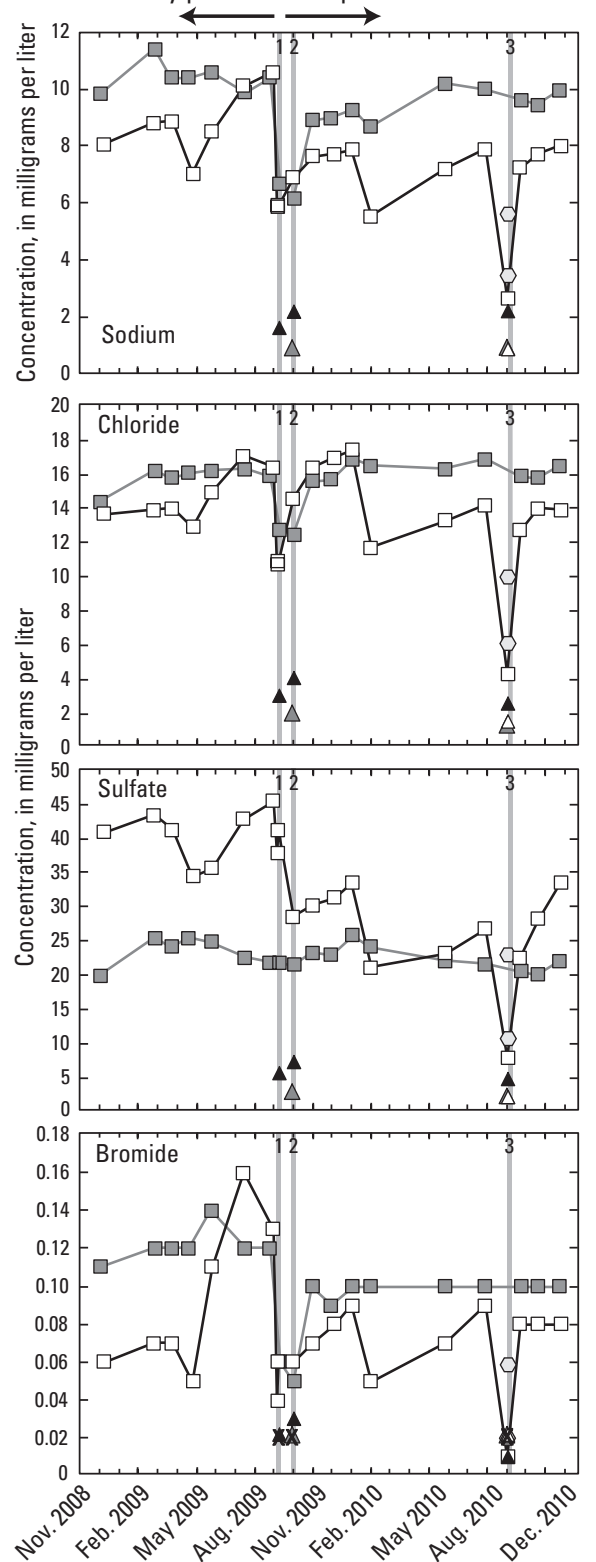

\section{EXPLANATION}

Onset of major storm and identifier

Surface water-

Continuous data

Blanco River at Halifax Ranch near Kyle, Texas (USGS station 08171290)

\section{Surface water-}

Sample, by stream

- Blanco River-Sample collection at Halifax Ranch near Kyle, Tex. (USGS station 08171290)

Blanco River-Sample collection near Kyle, Tex (USGS station 08171300)

- Guadalupe River-Sample collection at River Road near Sattler, Tex. (USGS station 08167990)

- Cibolo Creek-Sample collection at Farm Road 1863 below Bulverde, Tex. (USGS station 08184300)

Sink Creek-Sample collection at Sink Creek near San Marcos, Tex. (USGS station 08169932)

Purgatory Creek-Sample collection at Mountain High Drive near San Marcos, Tex. (USGS station 08169958)

\section{Nondetection}

shown at

the method

reporting level

USGS, U.S. Geological Survey

Figure 12. Time series (November 2008-December 2010) of selected physicochemical properties and geochemical constituents for surface-water sites sampled for the characterization of San Marcos Springs, south-central Texas. 

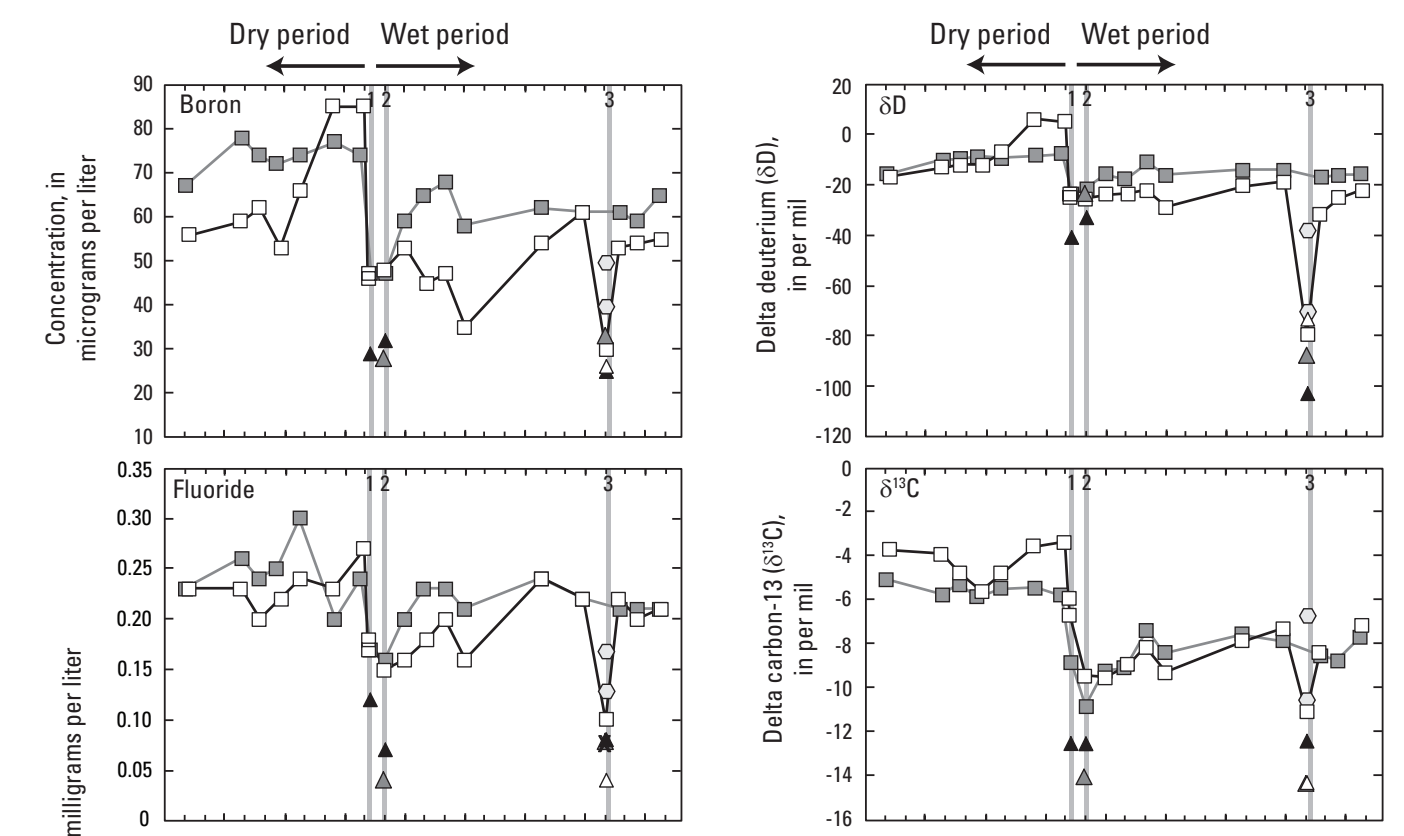

\section{EXPLANATION}

1 Onset of major storm and identifier

\section{Surface water-}

Sample, by stream

$\neg-$ Blanco River-Sample collection at Halifax Ranch near Kyle, Texas

(USGS station 08171290)

- Blanco River-Sample collection near Kyle, Tex. (USGS station 08171300)
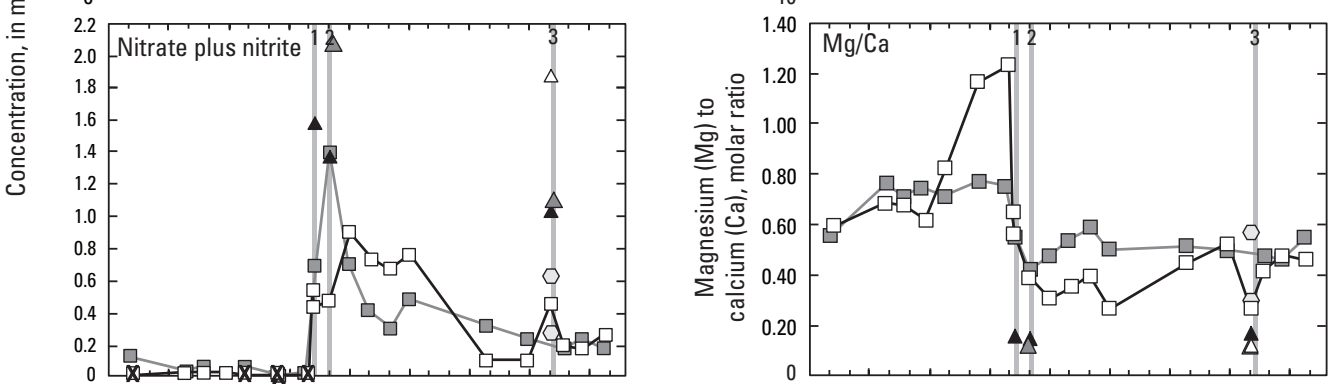

$\rightarrow \quad$ Guadalupe River-Sample collection at River Road near Sattler, Tex. (USGS station 08167990)

- Cibolo Creek-Sample

collection at Farm Road 1863 below Bulverde, Tex. (USGS station 08184300)

$\triangle \quad$ Sink Creek-Sample collection at Sink Creek near San Marcos, Tex. (USGS station 08169932)
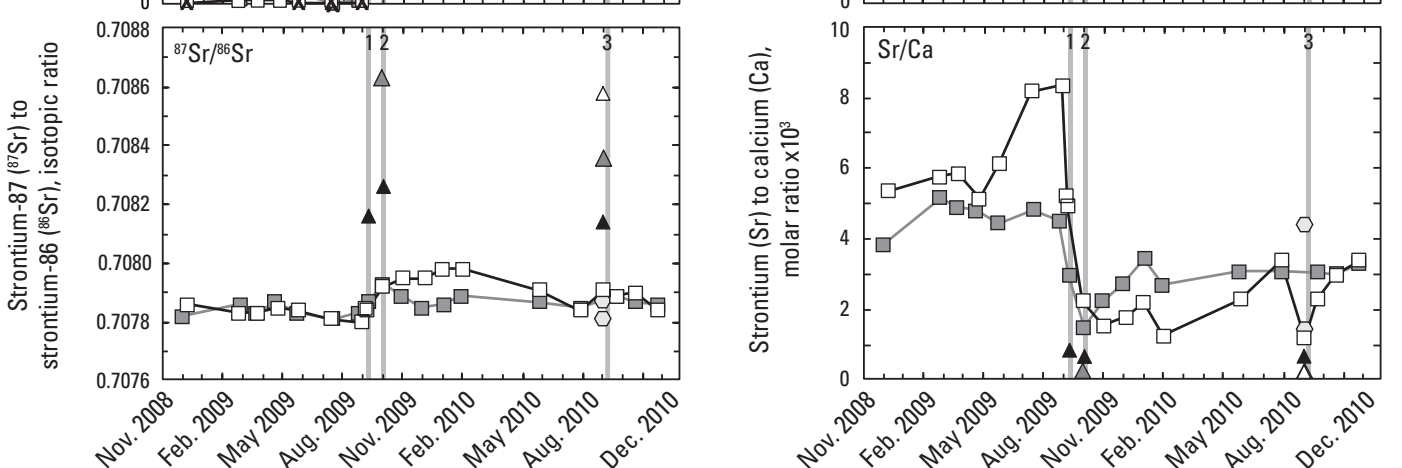

$\triangle \quad$ Purgatory Creek-Sample

collection at Mountain High

Drive near San Marcos, Tex.

(USGS station 08169958)

\section{$x$ Nondetection}

shown at

the method

reporting level

USGS, U.S. Geological Survey

Figure 12. Time series (November 2008-December 2010) of selected physicochemical properties and geochemical constituents for surface-water sites sampled for the characterization of San Marcos Springs, south-central Texas.-Continued 

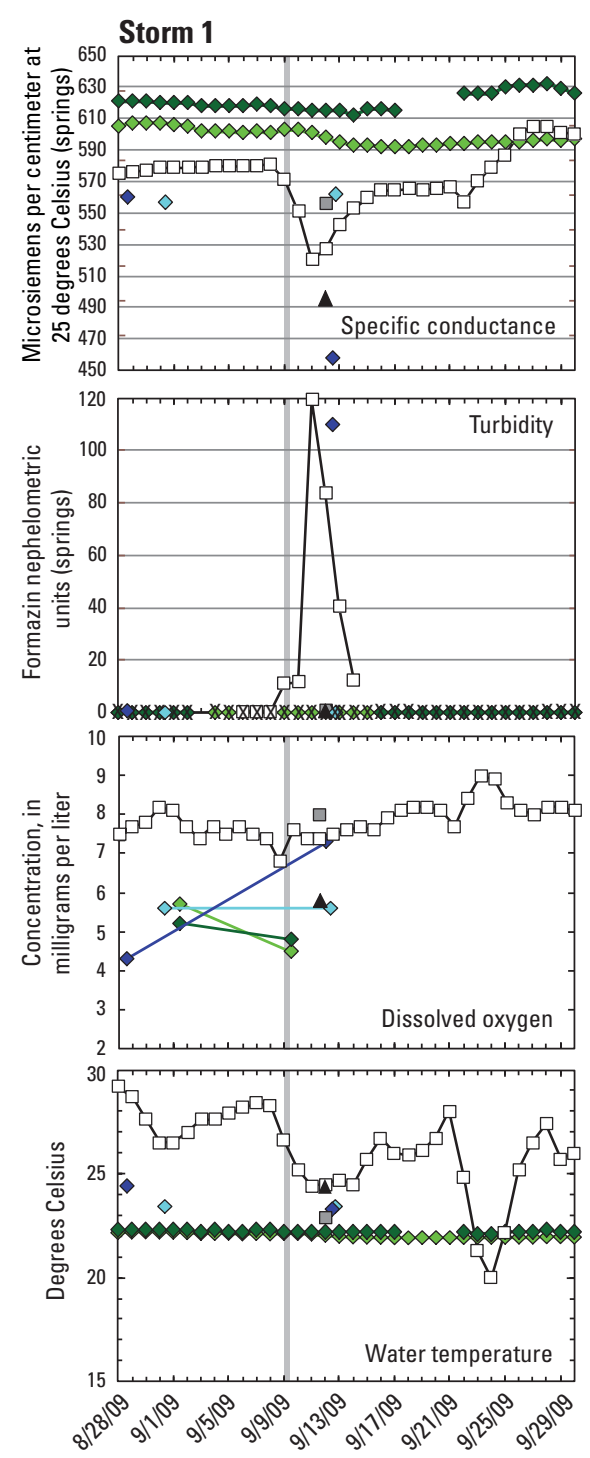

\section{Storm 2}
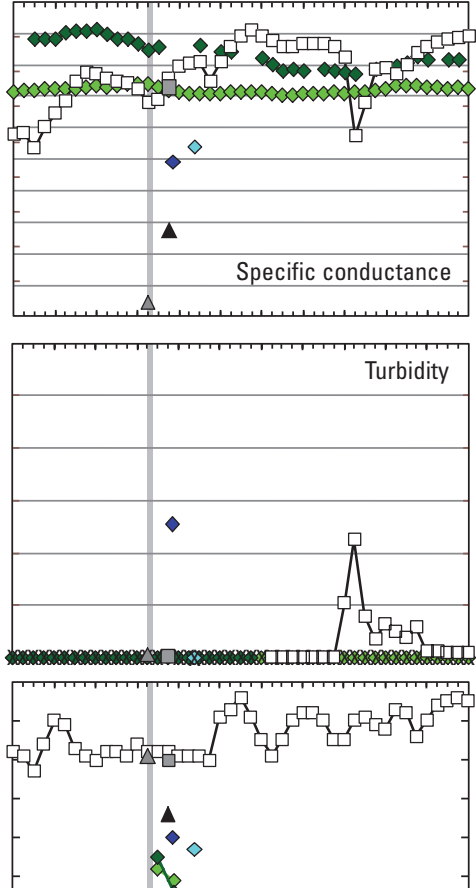

Dissolved oxygen

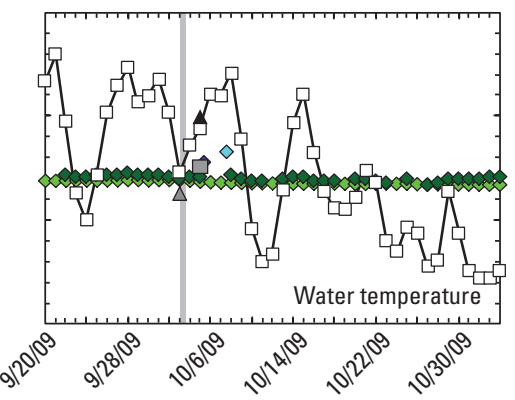

Date

\section{Storm 3}
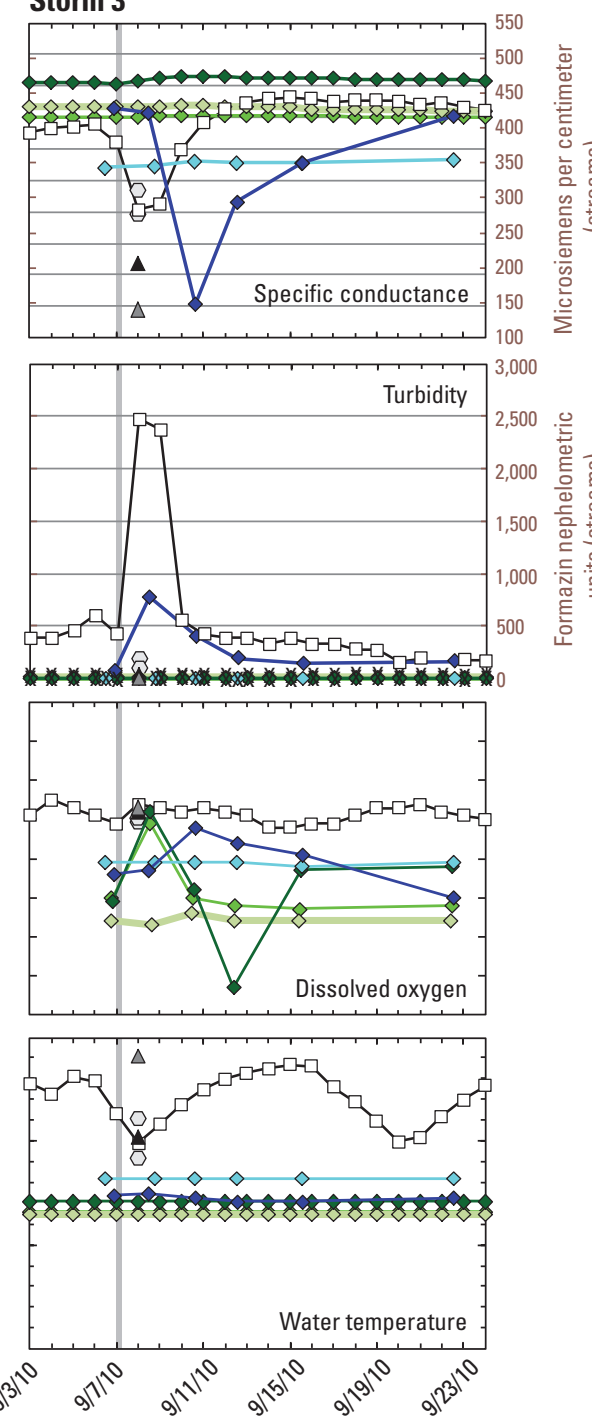

\section{EXPLANATION}

Onset of major storm

Spring, by orifice (table1)Sample

$\neg \quad$ Deep Spring

$\diamond \quad$ Diversion Spring

$\diamond \quad$ Weissmuller Spring

$\diamond \quad$ Comal Spring 1

$\checkmark \quad$ Hueco Spring A

Surface waterSample, by stream

$\rightarrow-$ Blanco River-Sample collection at Halifax Ranch near Kyle, Texas (USGS station 08171290)

- Blanco River-Sample

collection near Kyle, Tex. (USGS station 08171300)

- Guadalupe River-Sample collection at River Road near Sattler, Tex. (USGS station 08167990)

- Cibolo Creek-Sample collection at Farm Road 1863 below Bulverde, Tex. (USGS station 08184300)

$\triangle \quad$ Sink Creek-Sample collection at Sink Creek near San Marcos, Tex. (USGS station 08169932)

$\triangle \quad$ Purgatory Creek-Sample collection at Mountain High Drive near San Marcos, Tex. (USGS station 08169958)

$X$ Nondetection, shown at the method reporting level

USGS, U.S. Geological Survey

Figure 13. Time series (November 2008-December 2010) of physicochemical properties and geochemical constituents for surface-water sites and spring sites sampled preceding and in response to storm 1 (September 2009), storm 2 (October 2009), and storm 3 (September 2010), south-central Texas. 

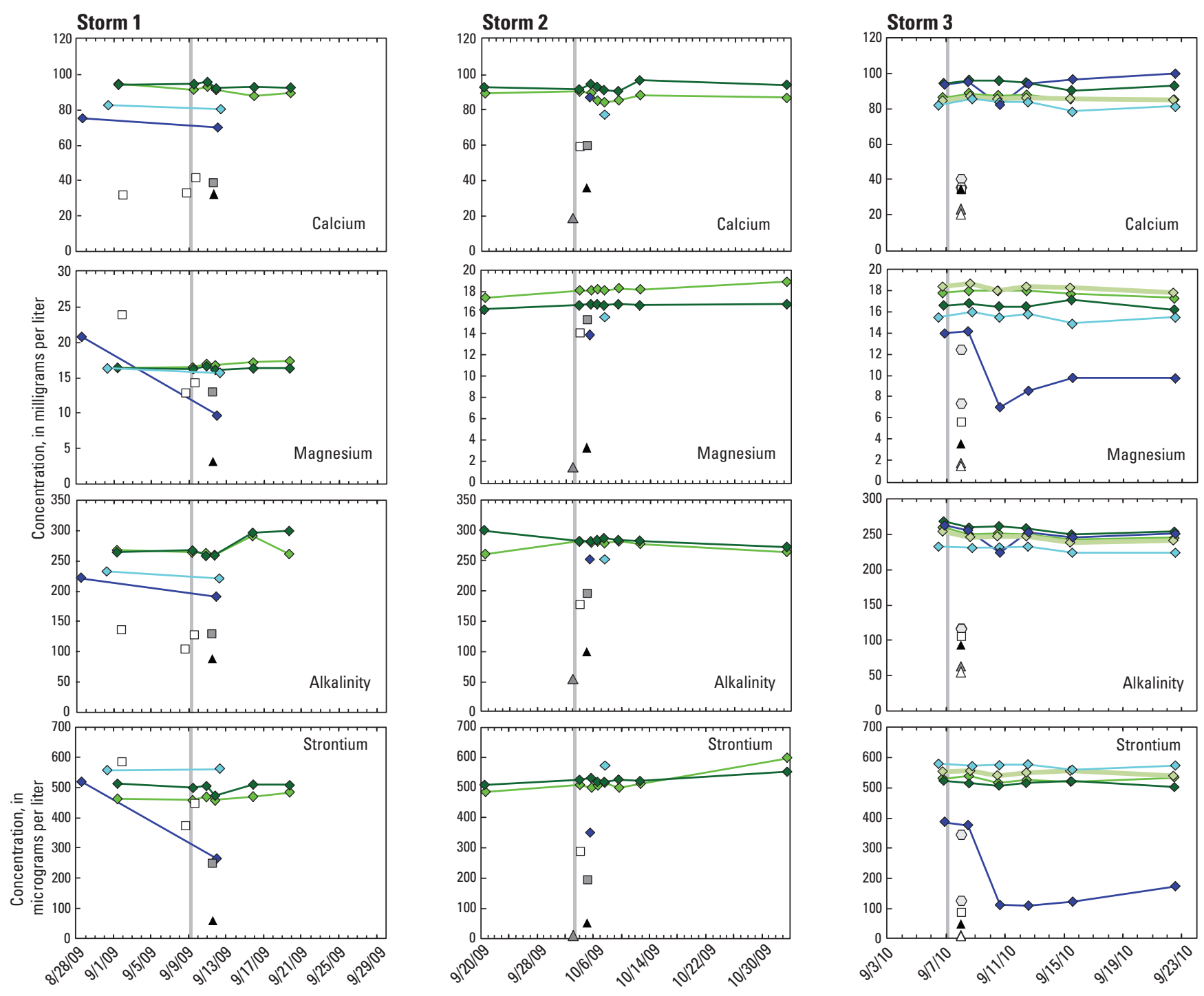

EXPLANATION

Onset of major storm

Spring, by orifice (table1) Sample

$\leftrightarrow \quad$ Deep Spring

$\diamond \quad$ Diversion Spring

$\diamond \quad$ Weissmuller Spring

$\diamond \quad$ Comal Spring 1

$\neg$ Hueco Spring A

Surface water-

Sample, by stream

․ Blanco River-Sample collection at Halifax

Ranch near Kyle, Texas (USGS station 08171290)

- Blanco River-Sample collection near Kyle, Tex. (USGS station 08171300)

口 Guadalupe River-Sample collection at River Road near Sattler, Tex. (USGS station 08167990)

- Cibolo Creek-Sample collection at Farm Road 1863 below Bulverde, Tex (USGS station 08184300)

$\triangle \quad$ Sink Creek-Sample collection at Sink Creek near San Marcos, Tex. USGS station 08169932)

Purgatory Creek-Sample collection at Mountain High Drive near San

Marcos, Tex.

(USGS station 08169958)

USGS, U.S. Geological Survey

Date

Figure 13. Time series (November 2008-December 2010) of physicochemical properties and geochemical constituents for surface-water sites and spring sites sampled preceding and in response to storm 1 (September 2009), storm 2 (October 2009) and storm 3 (September 2010), south-central Texas. -Continued 

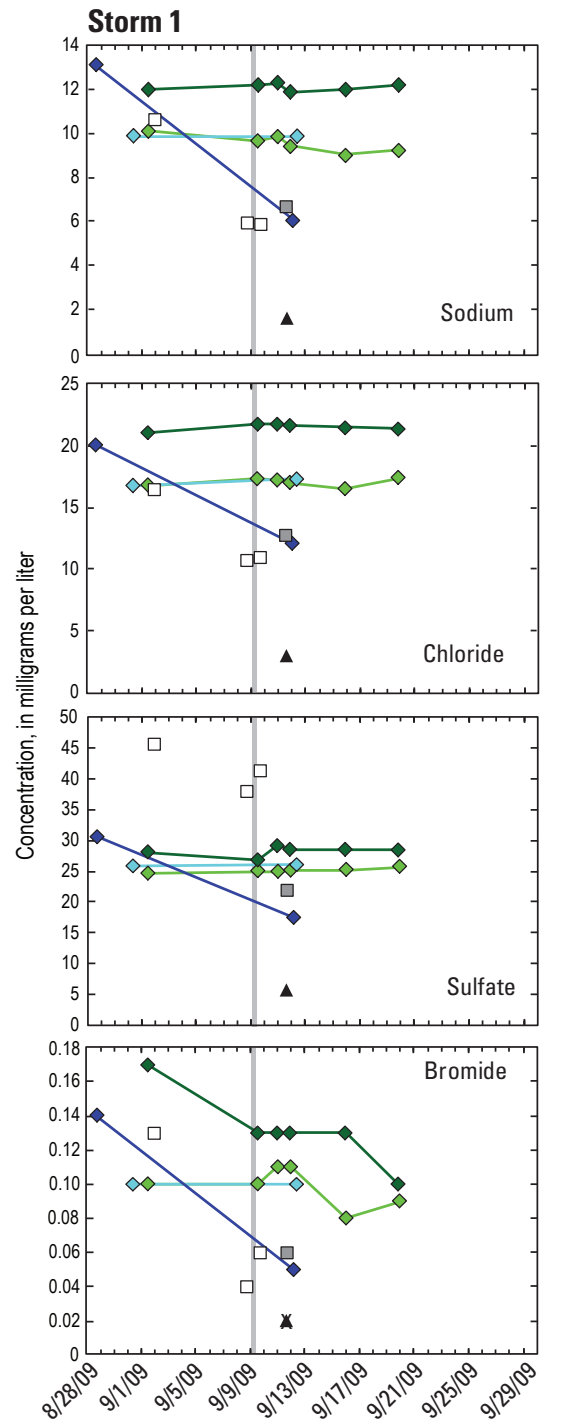

Storm 2
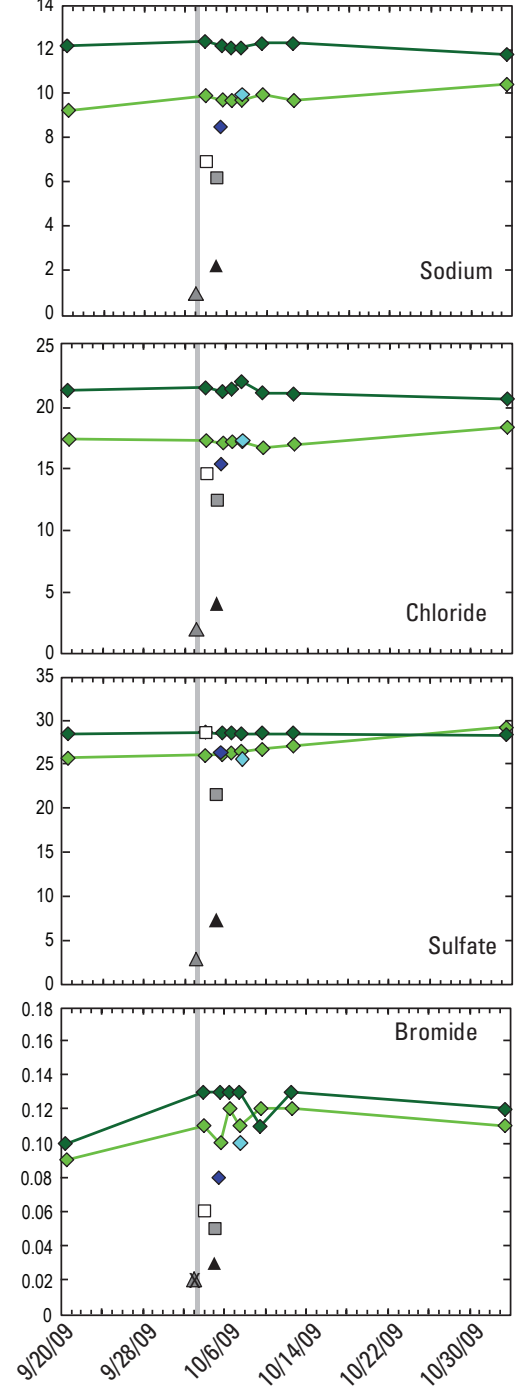

Date
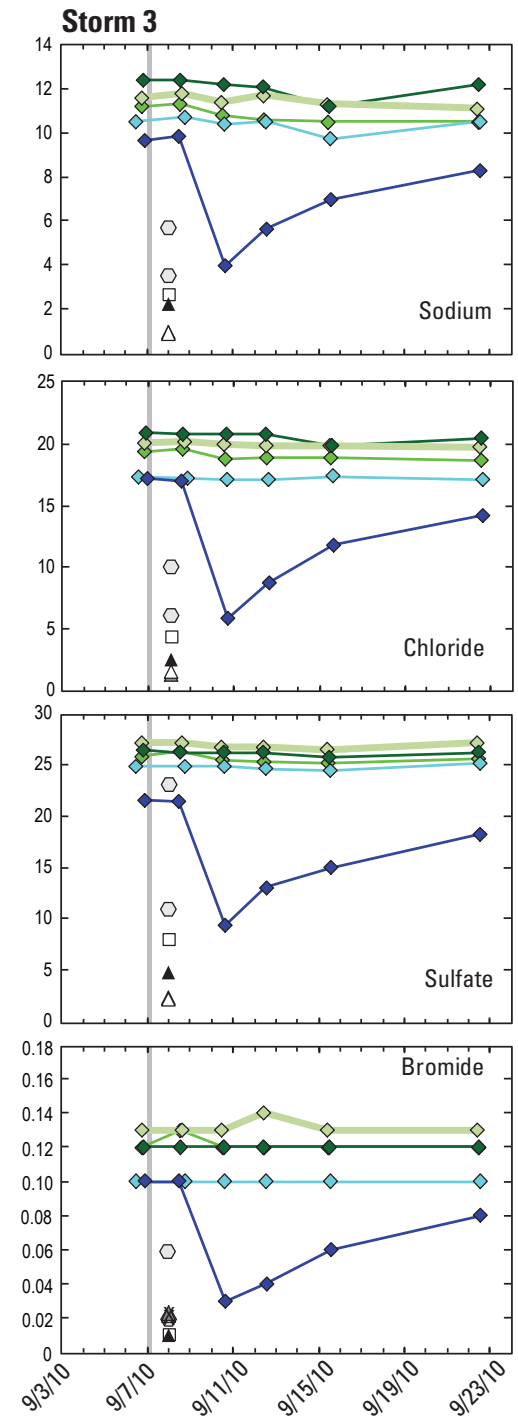

\section{EXPLANATION}

Onset of major storm

Spring, by orifice (table1) Sample

$\neg \quad$ Deep Spring

$\diamond \quad$ Diversion Spring

$\diamond \quad$ Weissmuller Spring

$\diamond \quad$ Comal Spring 1

$\rightarrow \quad$ Hueco Spring A

Surface water-

Sample, by stream

$\square \quad$ Blanco River-Sample collection at Halifax Ranch near Kyle, Texas (USGS station 08171290)

- Blanco River-Sample collection near Kyle, Tex. (USGS station 08171300)

- Guadalupe River-Sample collection at River Road near Sattler, Tex. (USGS station 08167990)

- Cibolo Creek-Sample collection at Farm Road 1863 below Bulverde, Tex. (USGS station 08184300)

$\triangle \quad$ Sink Creek-Sample collection at Sink Creek near San Marcos, Tex. (USGS station 08169932)

$\triangle \quad$ Purgatory Creek-Sample collection at Mountain High Drive near San Marcos, Tex.

(USGS station 08169958)

$x$ Nondetection, shown at

the method reporting level

USGS, U.S. Geological Survey

Figure 13. Time series (November 2008-December 2010) of physicochemical properties and geochemical constituents for surface-water sites and spring sites sampled preceding and in response to storm 1 (September 2009), storm 2 (October 2009) and storm 3 (September 2010), south-central Texas.-Continued 

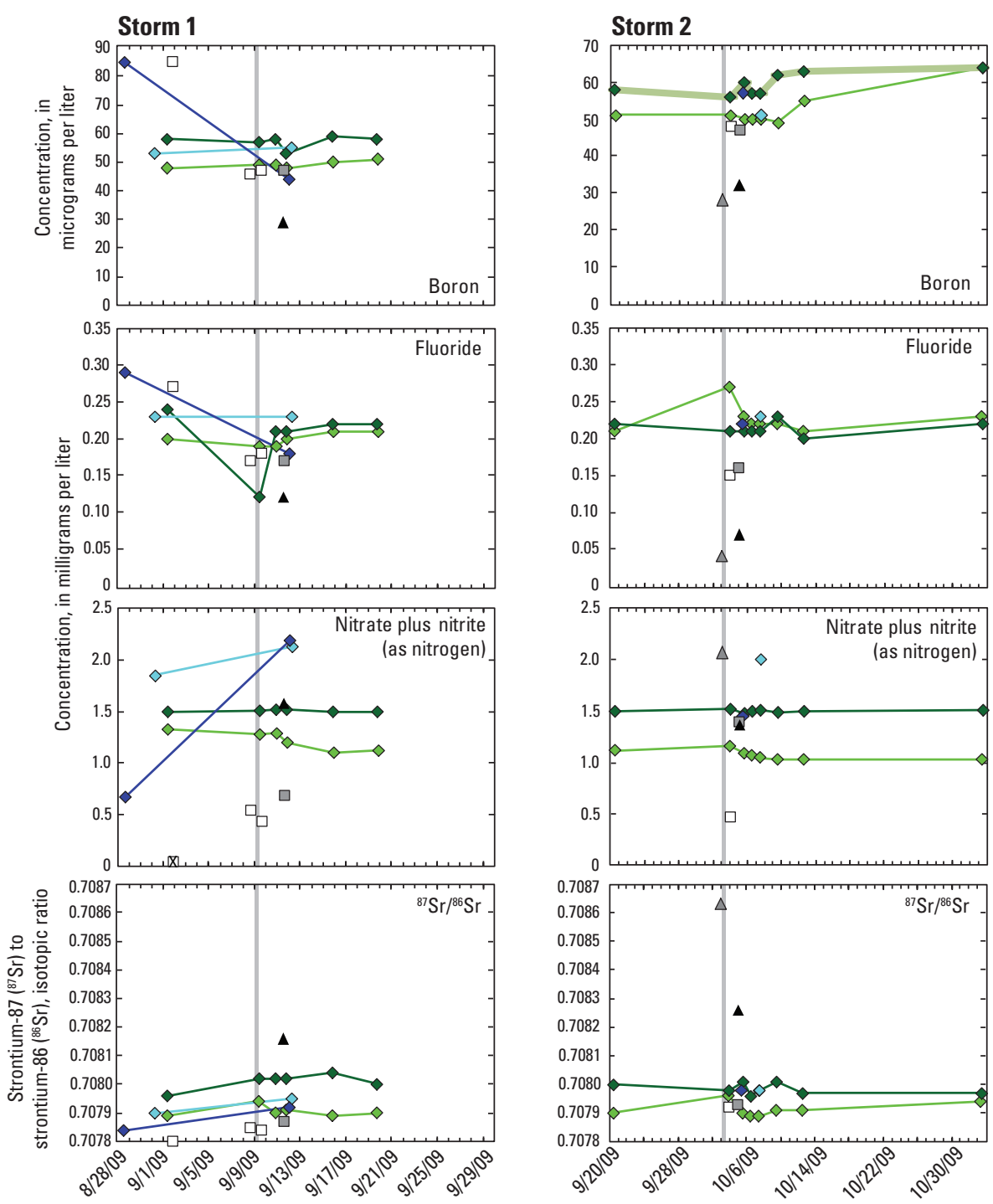

Date
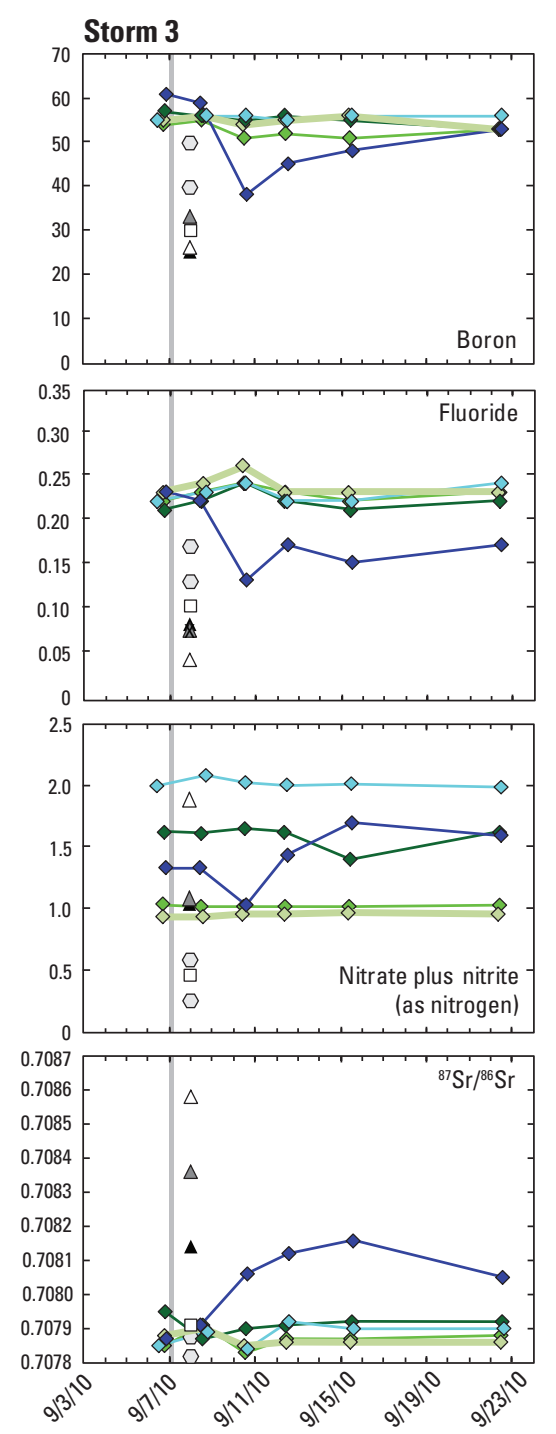

Figure 13. Time series (November 2008-December 2010) of physicochemical properties and geochemical constituents for surface-water sites and spring sites sampled

preceding and in response to storm 1 (September 2009), storm 2 (October 2009) and storm 3 (September 2010), south-central Texas.—Continued

\section{EXPLANATION}

Onset of major storm

Spring, by orifice (table1)Sample

$\neg \quad$ Deep Spring

$\diamond \quad$ Diversion Spring

$\diamond \quad$ Comal Spring 1

$\rightarrow \quad$ Hueco Spring A

Surface water-

Sample, by stream

$\square \quad$ Blanco River-Sample collection at Halifax Ranch near Kyle, Texas (USGS station 08171290)

- Blanco River-Sample collection near Kyle, Tex. (USGS station 08171300)

- Guadalupe River-Sample collection at River Road near Sattler, Tex. (USGS station 08167990)

- Cibolo Creek-Sample collection at Farm Road 1863 below Bulverde, Tex. (USGS station 08184300)

$\triangle \quad$ Sink Creek-Sample collection at Sink Creek near San Marcos, Tex. (USGS station 08169932)

$\triangle \quad$ Purgatory Creek-Sample collection at Mountain High Drive near San Marcos, Tex. (USGS station 08169958)

$X$ Nondetection, shown at the method reporting level

USGS, U.S. Geological Survey 

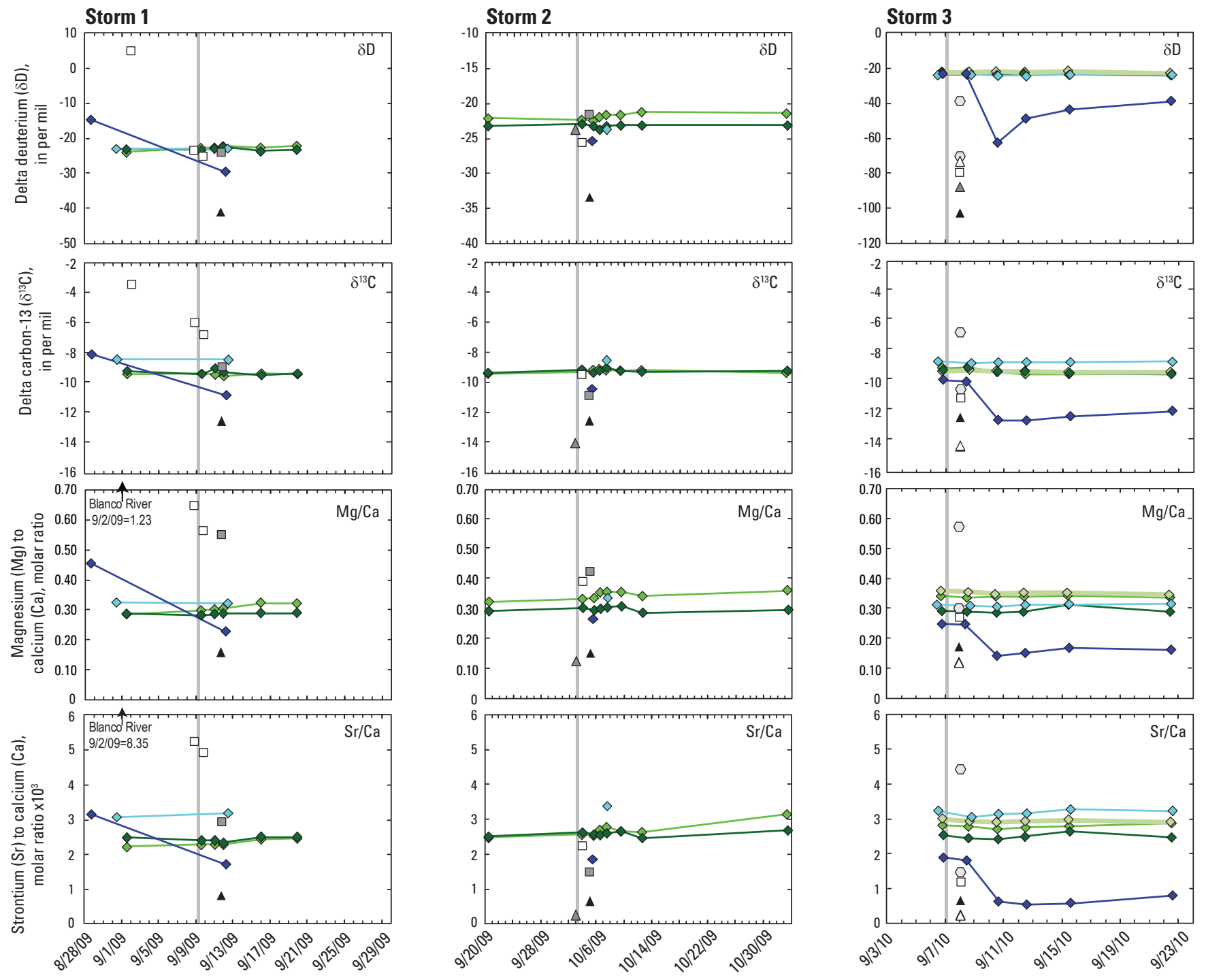

\section{EXPLANATION}

Onset of major storm

Spring, by orifice (table1) Sample

$\neg \quad$ Deep Spring

$\diamond \quad$ Diversion Spring

$\diamond \quad$ Weissmuller Spring

$\diamond \quad$ Comal Spring 1

$\multimap \quad$ Hueco Spring A

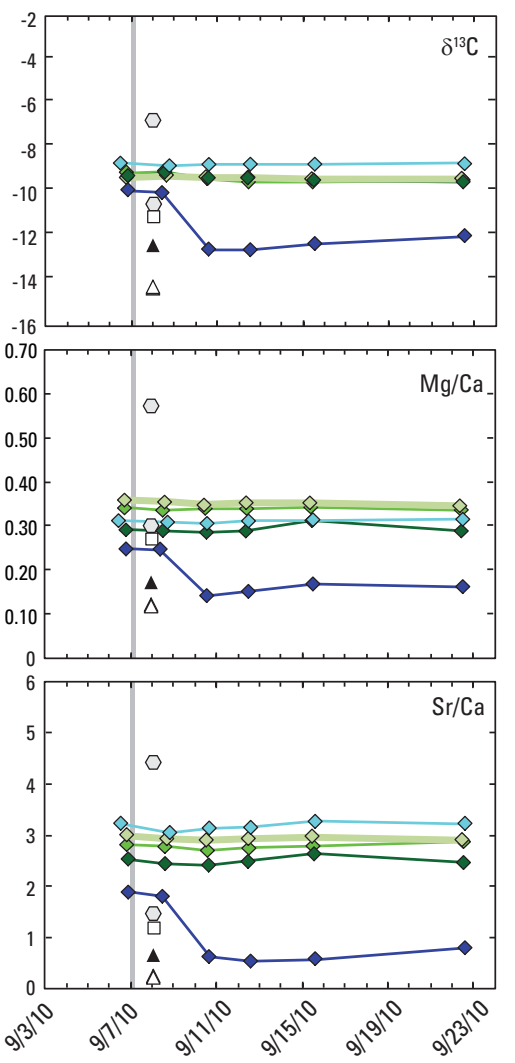

Surface water-

Sample, by stream

- Blanco River-Sample

collection at Halifax

Ranch near Kyle, Texas

(USGS station 08171290)

- Blanco River-Sample

collection near Kyle, Tex

(USGS station 08171300)

- Guadalupe River-Sample collection at River Road near Sattler, Tex. (USGS station 08167990)

- Cibolo Creek-Sample collection at Farm Road 1863 below Bulverde, Tex. (USGS station 08184300)

$\triangle \quad$ Sink Creek-Sample collection at Sink Creek near San Marcos, Tex. (USGS station 08169932)

$\triangle \quad$ Purgatory Creek-Sample collection at Mountain High Drive near San

Marcos, Tex.

(USGS station 08169958)

USGS, U.S. Geological Survey

Date

Figure 13. Time series (November 2008-December 2010) of physicochemical properties and geochemical constituents for surface-water sites and spring sites sampled preceding and in response to storm 1 (September 2009), storm 2 (October 2009) and storm 3 (September 2010), south-central Texas. -Continued 

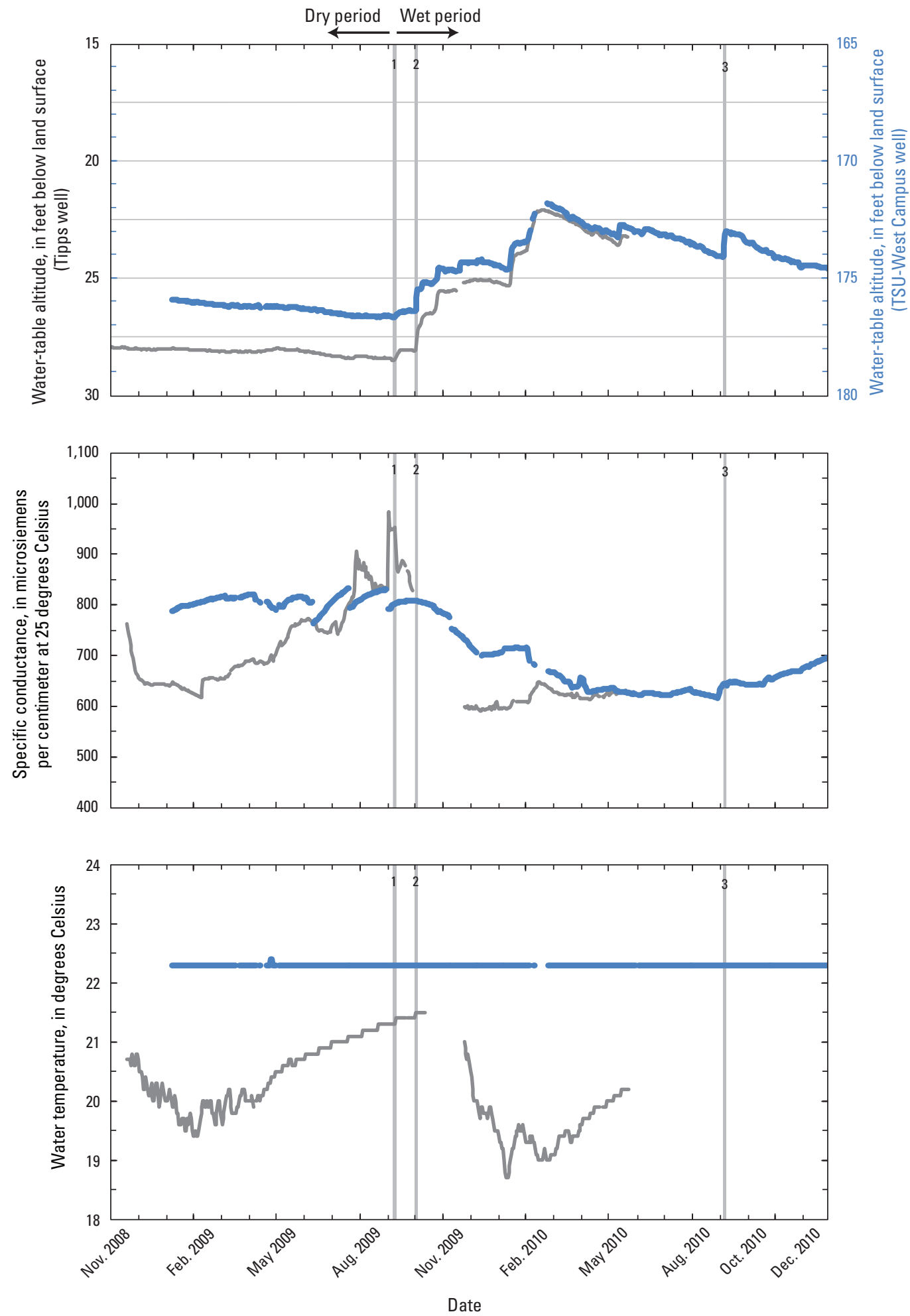

\section{EXPLANATION}

1 Onset of major storm and identifier

Groundwater well (table 1) —Continuous data

Tipps well

TSU-West Campus well

Figure 14. Times series (November 2008-December 2010) of hydrologic and physicochemical data for two groundwater wells (U.S. Geological Survey stations LR-67-01-809 [Tipps well] and LR-67-01-826 [TSU-West Campus well]) near San Marcos Springs, south-central Texas. 
wet period. Specific conductance values in the TSU-West Campus well declined rapidly when the well was pumped for routine water-quality sampling during the dry period. After sampling, specific conductance values over about a 4-week period returned to prepumping values and, in one instance, continued to increase beyond the prepumping values until the well was pumped for the next sample. The increase in specific conductance during the dry period at the Tipps well likely reflects mixing with a more saline groundwater source. Specific-conductance values at both wells during the dry period (median value of $692 \mu \mathrm{S} / \mathrm{cm}$ at the Tipps well and 810 $\mu \mathrm{S} / \mathrm{cm}$ at the TSU-West Campus well) were notably higher than for other Edwards aquifer wells (table 5) as well as higher than the median value for confined groundwater from the regional aquifer (525 $\mu \mathrm{S} / \mathrm{cm}$; Musgrove and others, 2010), indicating that both wells might be affected by mixing with a saline groundwater source.

Water temperature at the Tipps well varied seasonally between $18.7^{\circ} \mathrm{C}$ and $21.5^{\circ} \mathrm{C}$ with warmer temperatures in summer months and cooler temperatures in winter months. Water temperature at the TSU-West Campus well remained constant at $22.3^{\circ} \mathrm{C}$ during the entire study period, which is unexpected given the variability in water level and specific conductance.

The water-table altitude in both of the wells responded similarly to storms 1 and 2. After storms 1 and 2, water levels rose in both wells; the change was more substantial in response to storm 2 . The water-quality monitor in the Tipps well malfunctioned during storm 2, and specific conductance was not recorded; monitoring of the Tipps well was discontinued before storm 3 occurred. Specific conductance in the Tipps well decreased substantially in response to storm 1. Changes in specific conductance at the TSU-West Campus well in response to storms 1-3 were minor, indicating that the well was not affected by pulses of freshwater recharge moving rapidly to the well.

Physicochemical properties were measured for routine samples collected from four additional wells completed in the Edwards aquifer and three wells completed in the Trinity aquifer (figs. 15 and 16, respectively; tables 1 and 2). Well LR-58-57-512 (Ruby Ranch well) is completed in both the Edwards and Trinity aquifers; it is considered in this study as a Trinity aquifer wells since its geochemistry is dominantly influenced by the Trinity aquifer. Dry period and wet period statistics are summarized in table 5. With few exceptions, physicochemical properties for routine samples at both Edwards aquifer and Trinity aquifer wells were not significantly different between the dry period and the wet period. Results for routine samples from the Edwards aquifer wells consistently indicated that a decrease in specific conductance occurred in late July 2009 (fig. 15). These lower specific conductance values might be erroneous, as little rainfall and aquifer recharge occurred in July 2009 (figs. 5 and 7), and recorded values were qualified as estimated; major ion concentrations do not show notable corresponding decreases for these samples (fig. 15). Several high values for turbidity ( $>2$ FNU) were recorded at wells in both the dry and wet periods (fig. 15); these were generally not preceded or followed by high values and are likely anomalous (some are qualified as estimated). Most of the Edwards wells had higher-than-normal turbidity values (about 3 FNU) in December 2009.

Water temperature and specific conductance were notably higher at well LR-67-01-312 (hereinafter, the Aqua well) relative to other Edwards aquifer wells (fig. 15). The Aqua well had an anomalously low dissolved oxygen concentration on August 28, 2009, of $0.4 \mathrm{mg} / \mathrm{L}$ that was qualified as estimated. Some of the Edwards aquifer wells had specific conductance values similar to Comal Spring 1 (for example, wells DX-68-16-707 and LR-67-01-503, hereinafter the 4D and Neff wells, respectively) (fig. 15; table 5). Higher specific conductance values at the Aqua well were similar to values at San Marcos Springs, particularly at Deep Spring (fig. 15; table 5). Differences in physicochemical properties between the different wells likely reflect differences in flow paths supplying the wells.

\section{Springwater}

As noted previously, spring discharge values represent discharge for the spring complexes, whereas physicochemical and geochemical data were collected from individual spring orifices. Spring discharge was significantly higher at San Marcos, Comal, and Hueco Springs during the wet period relative to the dry period (table 5).

Deep, Diversion, and Weissmuller Springs, in the San Marcos Springs complex, were monitored continuously for physicochemical properties (fig. 17). At Comal Spring 1 and Hueco Spring A, physicochemical properties were measured with routine and storm samples (fig. 18). At San Marcos Springs, water temperature was generally stable with variations of $0.9^{\circ} \mathrm{C}$ at Deep Spring, $0.6^{\circ} \mathrm{C}$ at Diversion Spring and less than $0.1^{\circ} \mathrm{C}$ at Weissmuller Spring (which had a shorter monitoring interval). Water temperature at Deep Spring fluctuated seasonally with the highest values occurring during the summer months and the lowest values occurring during the winter months. Diversion Spring did not show seasonal variations in temperature.

Deep Spring had significantly higher specific conductance values (median of $613 \mu \mathrm{S} / \mathrm{cm}$ ) than did Diversion or Weissmuller Springs (median for each of $595 \mu \mathrm{S} / \mathrm{cm}$ ) (fig. 17). Specific conductance values were slightly lower in the wet period than in the dry period at both Deep and Diversion Springs (table 5). (The variability of specific conductance at San Marcos Springs is discussed in detail later in the report in the section "Specific Conductance and Spring Discharge.")

Turbidity values were low ( $<1$ FNU) at Deep, Diversion, and Weissmuller Springs throughout the study period and did not vary consistently from the dry period to the wet period (table 5). At both Deep and Diversion Springs, turbidity values were mostly below detection ( $<0.3 \mathrm{FNU}$ ) (fig. 17); slightly higher turbidity values were measured at Weissmuller Spring, with a median of 0.6 FNU. After a rain event in mid-July 2010, turbidity values at Weissmuller Spring increased to $0.8 \mathrm{FNU}$ 

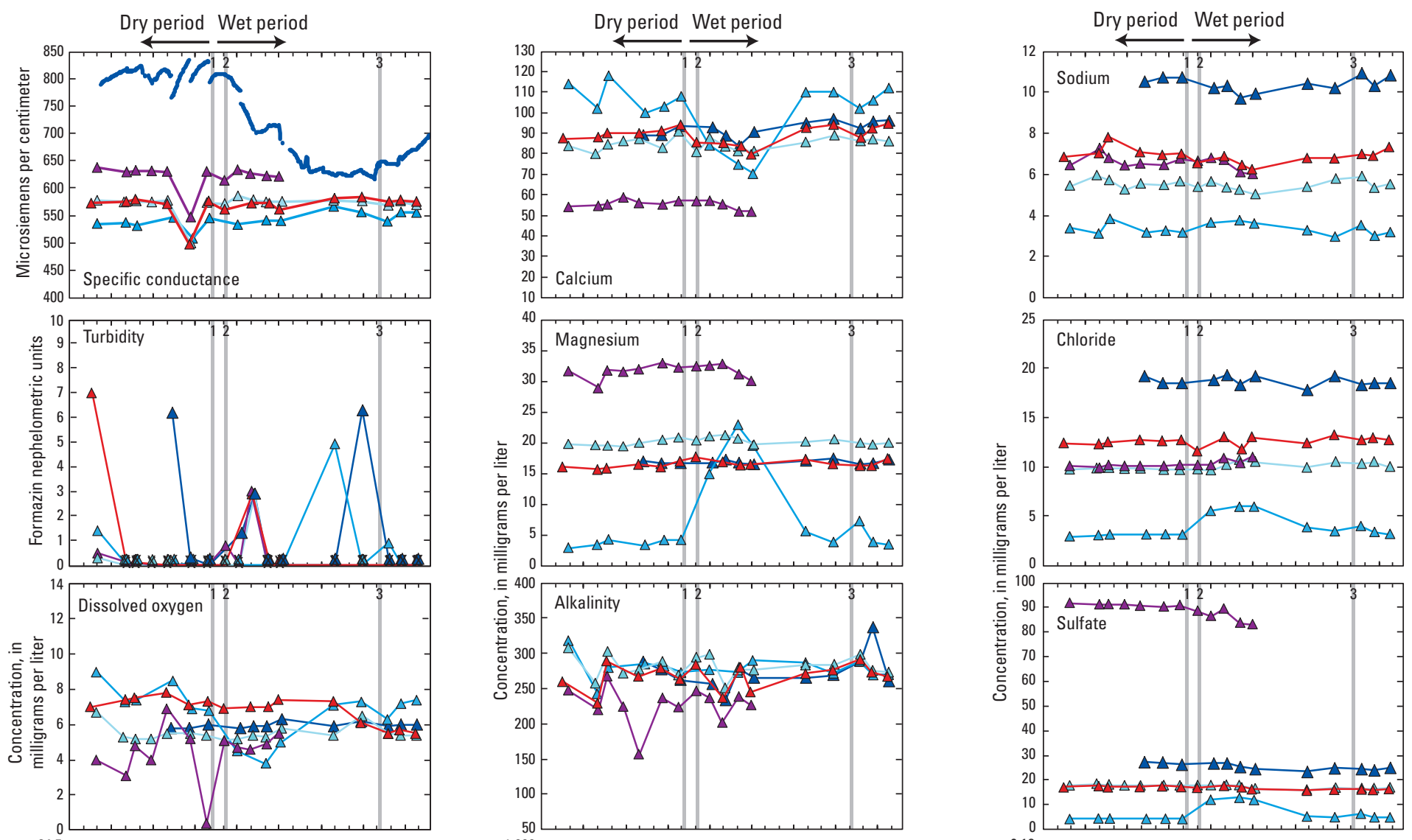

EXPLANATION
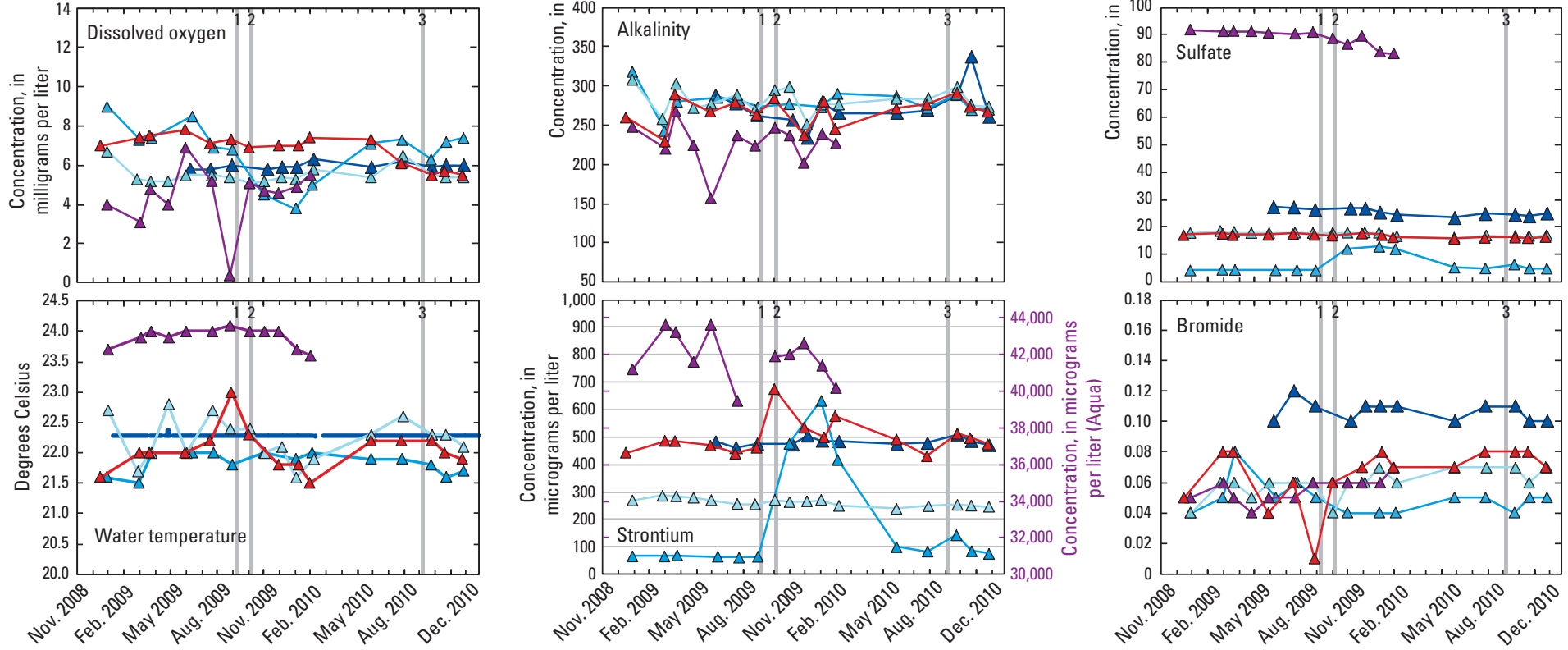

Onset of major storm

and identifier

Edwards aquifer well

(table 1)-Continuous data

- TSU-West Campus

Edwards aquifer well

(table 1)-Sample

$\triangle \quad$ TSU-West Campus

Solar

$\triangle$ Neff

$\triangle$ Aqua

$\triangle 4 \mathrm{D}$

$x$ Nondetection,

shown at

the method

or laboratory

reporting level

Date

Figure 15. Time series (November 2008-December 2010) of selected physicochemical properties and geochemical constituents for Edwards aquifer groundwater wells sampled for the characterization of San Marcos Springs, south-central Texas. 

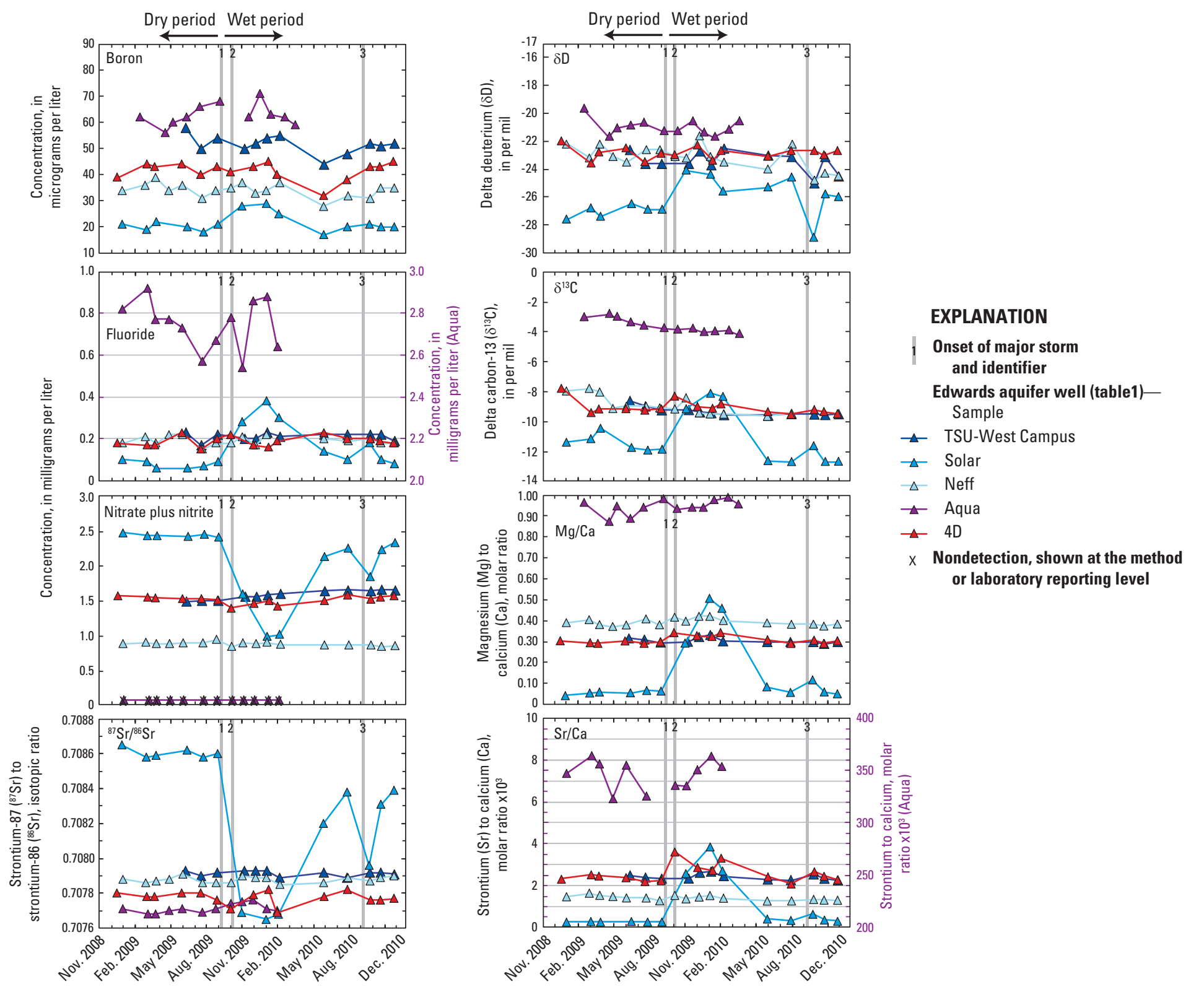

Date

Figure 15. Time series (November 2008-December 2010) of selected physicochemical properties and geochemical constituents for Edwards aquifer groundwater wells sampled for the characterization of San Marcos Springs, south-central Texas. - Continued 

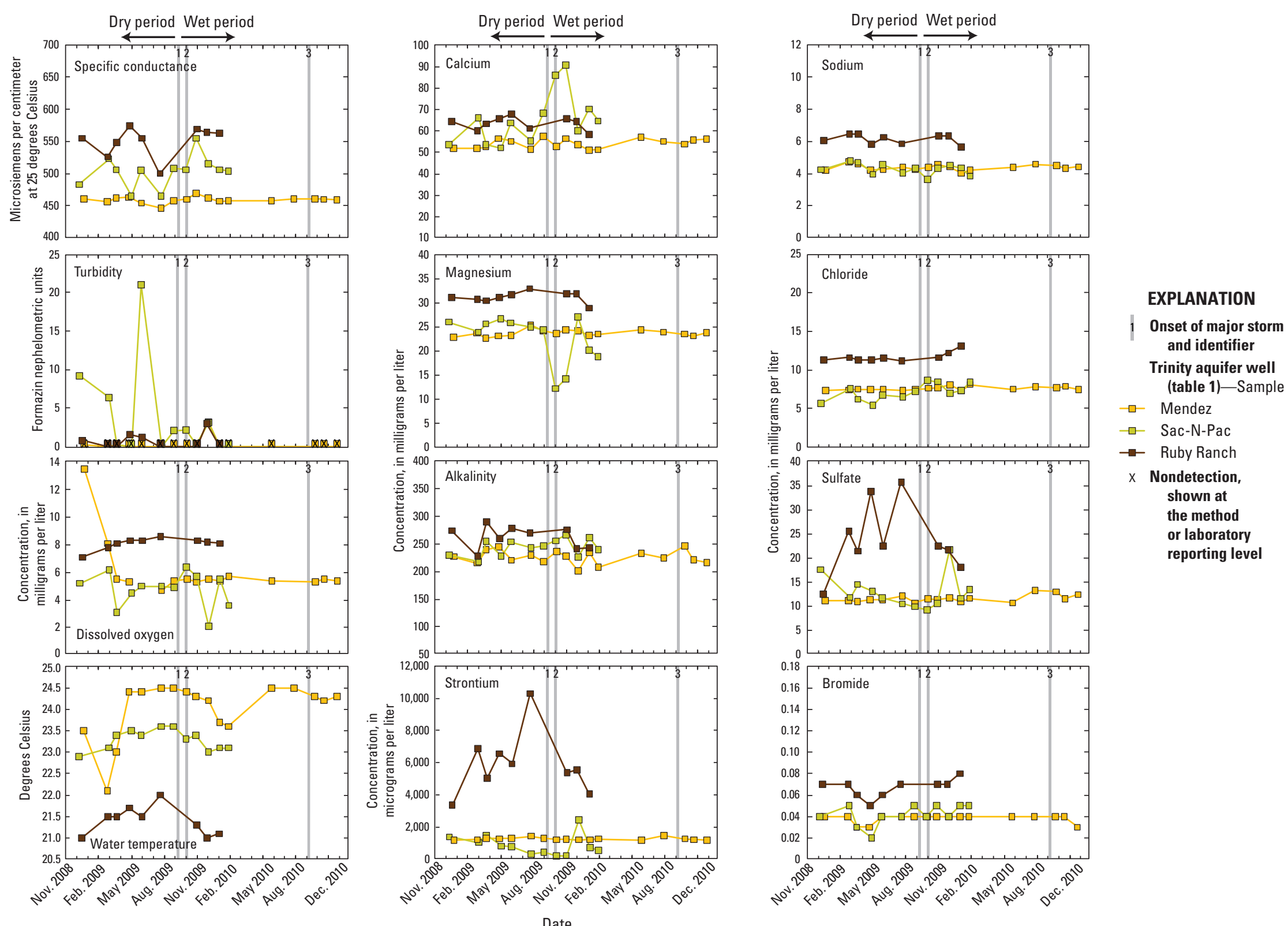

Figure 16. Time series (November 2008-December 2010) of selected physicochemical properties and geochemical constituents for Trinity aquifer groundwater wells sampled for the characterization of San Marcos Springs, south-central Texas. 

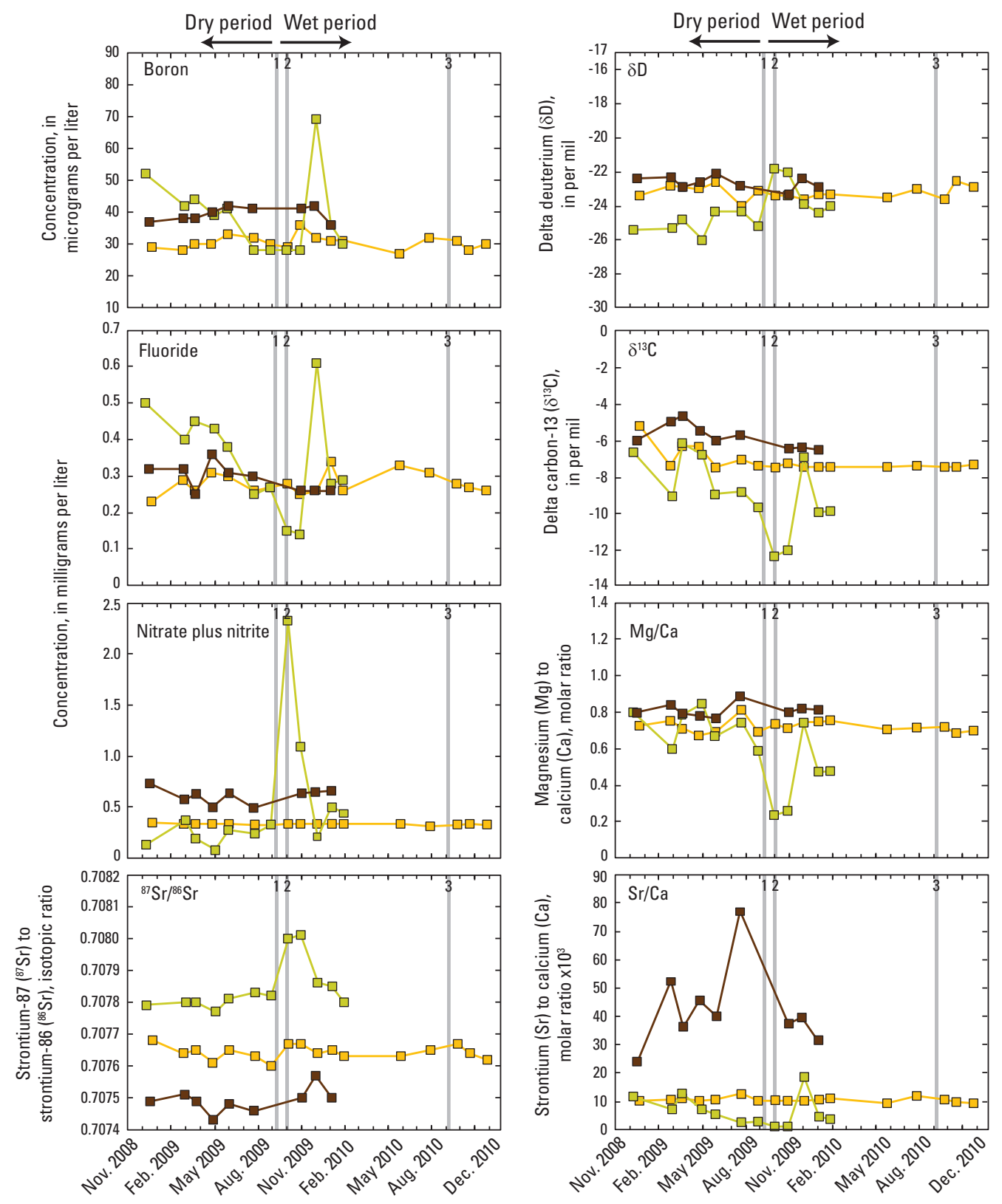

\section{EXPLANATION}

1 Onset of major storm and identifier

Trinity aquifer well

(table 1)-Sample

$\square-$ Mendez

$\square$ Sac-N-Pac

$\rightarrow$ Ruby Ranch

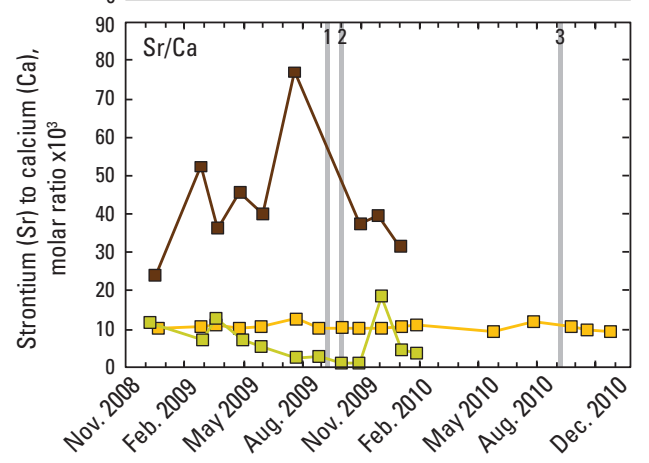

Date

Figure 16. Time series (November 2008-December 2010) of selected physicochemical properties and geochemical constituents for Trinity aquifer groundwater wells sampled for the characterization of San Marcos Springs, south-central Texas. - Continued 


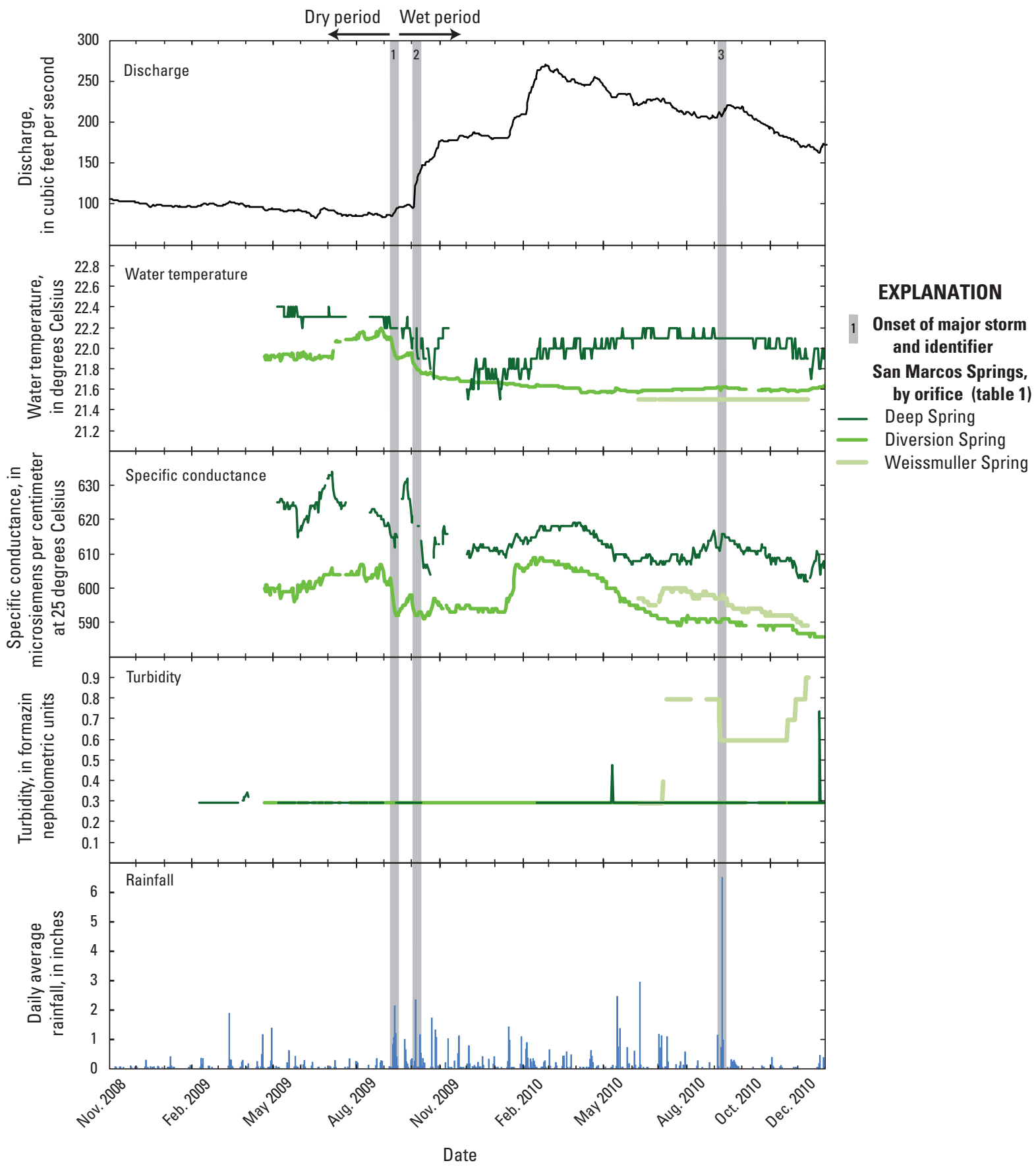

Figure 17. Times series (November 2008-December 2010) of discharge at San Marcos Springs (U.S. Geological Survey station 08170000 San Marcos Springs at San Marcos, Texas), selected physicochemical properties at San Marcos Springs orifices (Deep, Diversion, and Weissmuller Springs), and daily average rainfall in the vicinity of San Marcos Springs, south-central Texas (mean for National Weather Service Cooperative Stations 411429, 412585, 416276, 417983, 418544, and 419815, National Oceanic and Atmospheric Administration, 2011). 
and remained higher throughout the rest of the study period. On 2 days, turbidity values at Deep Spring were anomalously high: on May 12, 2010, the daily mean turbidity value was 0.5 FNU, and on December 26, 2010, it was 0.7 FNU (fig. 17). The 15-minute data for these 2 days show an increase and subsequent decrease in turbidity over the entire day. The source of these higher turbidity values is unknown.

Dissolved oxygen values were inversely correlated with spring discharge at Diversion Spring (Kendall's tau of -0.44) and were significantly lower during the wet period (table 5). At Deep Spring, dissolved oxygen values were similar during the dry and wet periods.

Physicochemical properties showed little variability from the dry period to the wet period at Comal Spring 1 (table 5; fig. 18). An anomalously high turbidity value of 3.8 FNU was measured on December 3, 2009; the reason for this high value is unknown, but it is inconsistent with low $(<0.3$ FNU) turbidity values measured at this site throughout the study. Specific conductance values at Comal Spring 1 (median of 558 $\mu \mathrm{S} / \mathrm{cm}$ ) were significantly lower than at Deep, Diversion, and Weissmuller Springs. Median dissolved oxygen values at Comal Spring 1 were slightly higher during the wet period than during the dry period (table 5). At Hueco Spring A, physicochemical properties varied considerably over the study period; specific conductance and turbidity values responded rapidly to storm events, and temperature varied seasonally (fig. 18).

\section{Geochemical Variability Associated with Routine Sampling}

Samples were collected periodically during December 2008-December 2010 (routine samples) from two stream sites, eight groundwater wells (five completed in the Edwards aquifer and three completed in the Trinity aquifer), and five springs (three orifices of San Marcos Springs, Hueco Spring A, and Comal Spring 1). Geochemical changes during this period reflect a transition from exceptional drought to wetter-thannormal conditions.

\section{Surface Water}

Selected geochemical data from routine water-quality samples collected at Blanco at Halifax and Guadalupe at River Road are shown in figure 12; summary statistics are shown in table 5. Samples from both streams showed some similar variations from the dry period to the wet period. Wet period samples had significantly lower $\mathrm{Mg}, \mathrm{Na}, \mathrm{Sr}$, boron (B), and fluoride (F) concentrations, $\mathrm{Mg} / \mathrm{Ca}$ and $\mathrm{Sr} / \mathrm{Ca}$ ratios, and stable isotopes (carbon $\left[\delta^{13} \mathrm{C}\right], \delta \mathrm{D}, \delta^{18} \mathrm{O}$ ); wet period samples also had higher $\mathrm{Ca}$ and nitrate plus nitrate $\left(\mathrm{NO}_{3}+\mathrm{NO}_{2}\right)$ concentrations and $\mathrm{Sr}$ isotope ratios $\left({ }^{87} \mathrm{Sr} /{ }^{86} \mathrm{Sr}\right.$ ) (table 5). Samples from the Blanco at Halifax also had lower $\mathrm{SO}_{4}$ concentrations during the wet period relative to the dry period. During the dry period, samples from the Blanco at Halifax had notably higher concentrations of $\mathrm{Sr}$ and $\mathrm{SO}_{4}$ relative to samples from the Guadalupe at River Road. These differences might result from Trinity aquifer sourced springs contributing to base flow in the Blanco River during the dry period; differences in stratigraphy and lithology of the basins of the Blanco and Guadalupe Rivers might also contribute to differences between the geochemistry of the two streams. As discharge at Blanco at Halifax and Guadalupe at River Road increased during the transition from the dry period to the wet period, substantial changes in geochemistry occurred in the streams. Nineteen of 28 constituents (physicochemical and geochemical) from samples collected at Blanco at Halifax and at Guadalupe at River Road were statistically different when comparing the dry period to the wet period (table 5). In general, as stream discharge increased from the dry period to the wet period, dissolved oxygen concentrations, specific conductance, turbidity, and $\mathrm{Ca}$ concentrations increased in both streams (fig. 12). Concentrations of $\mathrm{Mg}, \mathrm{Sr}, \mathrm{Na}, \mathrm{SO}_{4}, \mathrm{~B}$, and $\mathrm{F}$ decreased as stream discharge increased (fig. 12), likely resulting from the dilution effect of recent rainfall and runoff. Nitrate plus nitrite concentrations increased from the dry period to the wet period but remained lower than concentrations observed in Edwards aquifer wells and springs (table 5). Concentrations of $\mathrm{NO}_{3}+\mathrm{NO}_{2}$ increased markedly at the onset of the wet period then generally decreased throughout the remainder of the wet period (fig. 12); this pattern is consistent with a flush of nitrification from the rewetting of soils following a drought (Lucey and Goolsby, 1993; Reynolds and Edwards, 1995), which has been previously demonstrated to have occurred for the same sampling period in the Barton Springs segment of the Edwards aquifer (Mahler and others, 2011). Higher ${ }^{87} \mathrm{Sr} r{ }^{86} \mathrm{Sr}$ values for stream samples during the wet period relative to the dry period likely reflect increased interaction of rainfall and runoff with more radiogenic (higher ${ }^{87} \mathrm{Sr} r{ }^{86} \mathrm{Sr}$ values) surface soils (Musgrove and Banner, 2004).

\section{Groundwater}

\section{Edwards Aquifer}

Selected geochemical data from routine samples collected from five wells completed in the Edwards aquifer (fig. 1) are shown in figure 15; summary statistics are shown in table 5. When comparing the geochemistry of the five wells, there are some differences in water chemistry that likely reflect different flow paths within the Edwards aquifer that supply the wells and, consequently, different water sources and different extents of water-rock interaction. Three of the wells (TSU-West Campus, Neff, and 4D) had generally similar compositions for numerous constituents during both the dry and wet periods (fig. 15), although the TSU-West Campus well had notably higher $\mathrm{Na}, \mathrm{Cl}$, and bromide $(\mathrm{Br})$ concentrations than did the other Edwards aquifer wells. The geochemistry of the Aqua well was distinct in comparison to the other Edwards aquifer wells, with higher concentrations of $\mathrm{Mg}, \mathrm{Sr}, \mathrm{SO}_{4}, \mathrm{~F}$, and $\mathrm{B}$; higher ratios of $\mathrm{Mg} / \mathrm{Ca}$ and $\mathrm{Sr} / \mathrm{Ca}$; lower concentrations of $\mathrm{Ca}$ and $\mathrm{NO}_{3}+\mathrm{NO}_{2}$; and higher water temperature and $\delta^{13} \mathrm{C}$ values (fig. 15). 

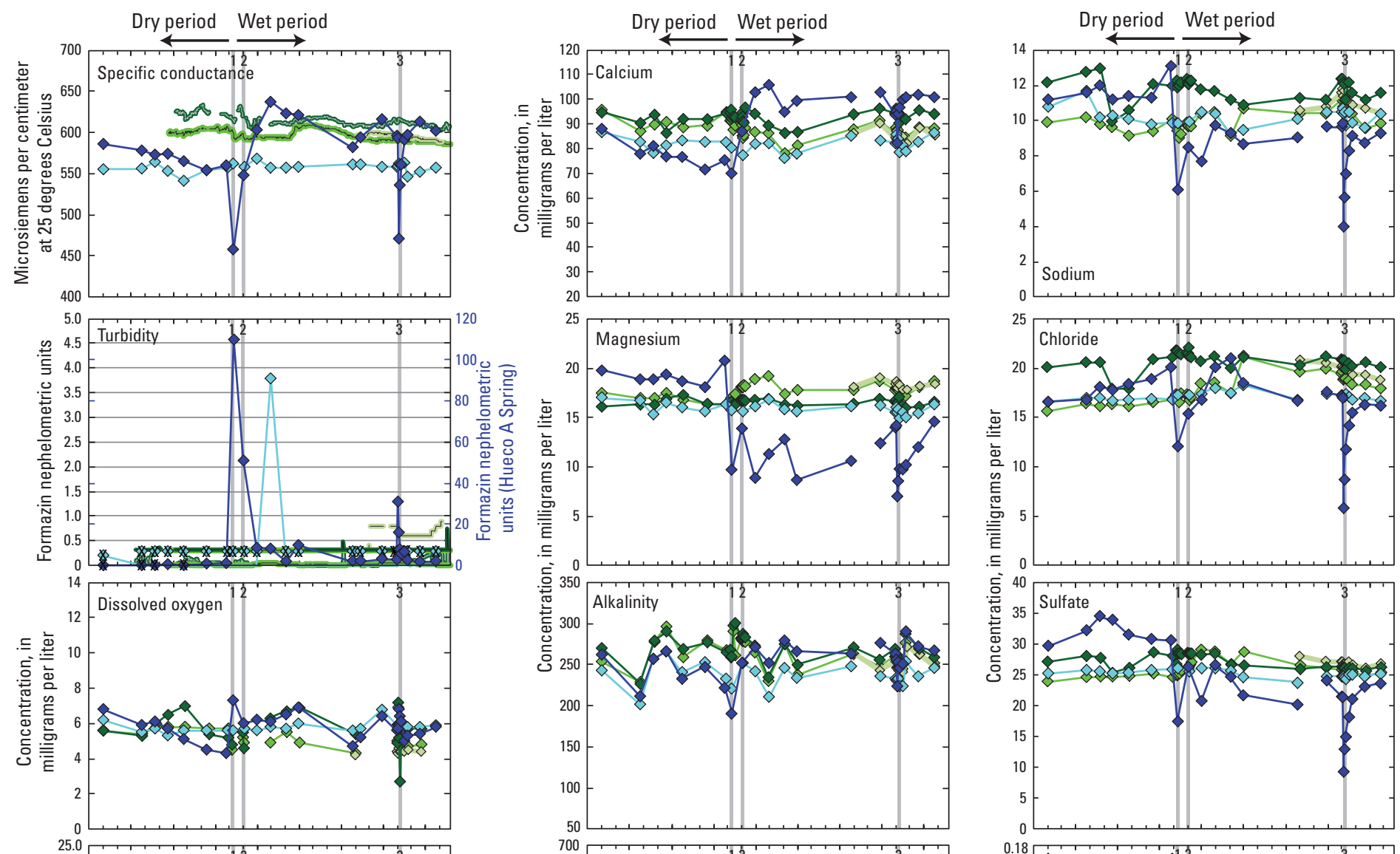

\section{EXPLANATION}

Onset of major storm and identifier

Spring, by orifice

(table 1) - Continuous
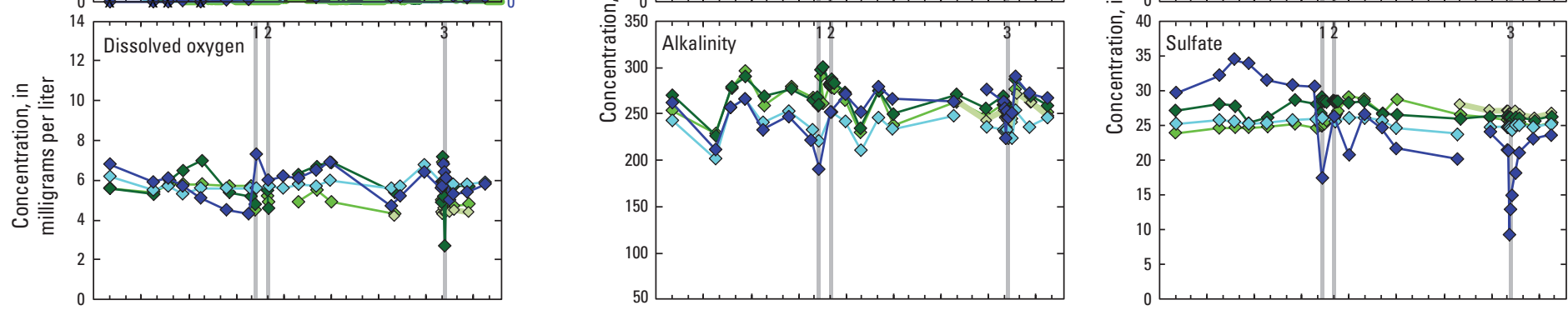

- Deep Spring

— Diversion Spring

- Weissmuller Spring

Spring (table1)—Sample

$\rightarrow$ Deep Spring

$\diamond \quad$ Diversion Spring

$\diamond \quad$ Weissmuller Spring

$\diamond \quad$ Comal Spring 1

$\neg$ Hueco Spring A

$X$ Nondetection,

shown at

the method
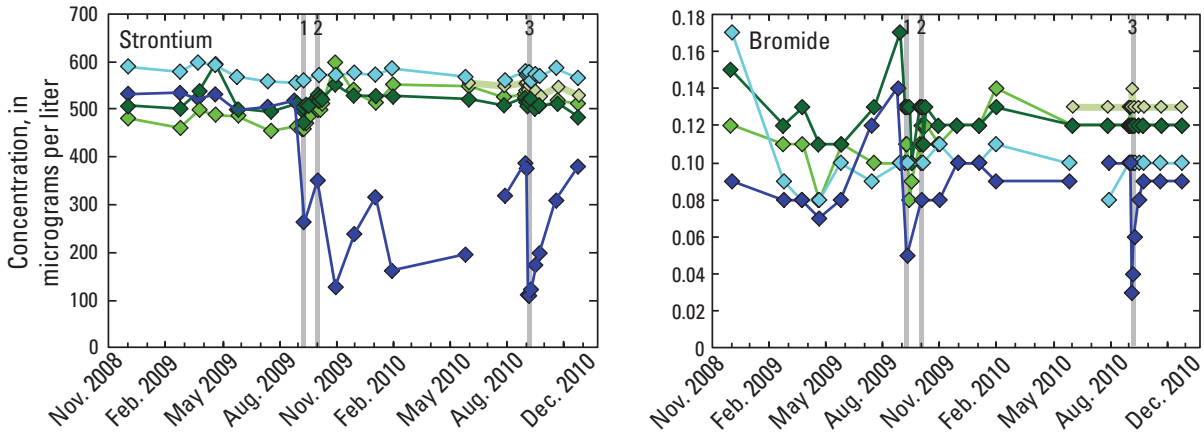

or laboratory

reporting level

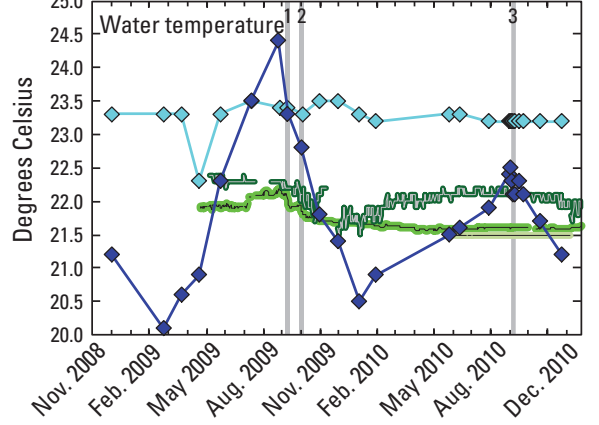

Figure 18. Time series (November 2008-December 2010) of selected physicochemical properties and geochemical constituents for Edwards aquifer springs sampled for the characterization of San Marcos Springs, south-central Texas. 

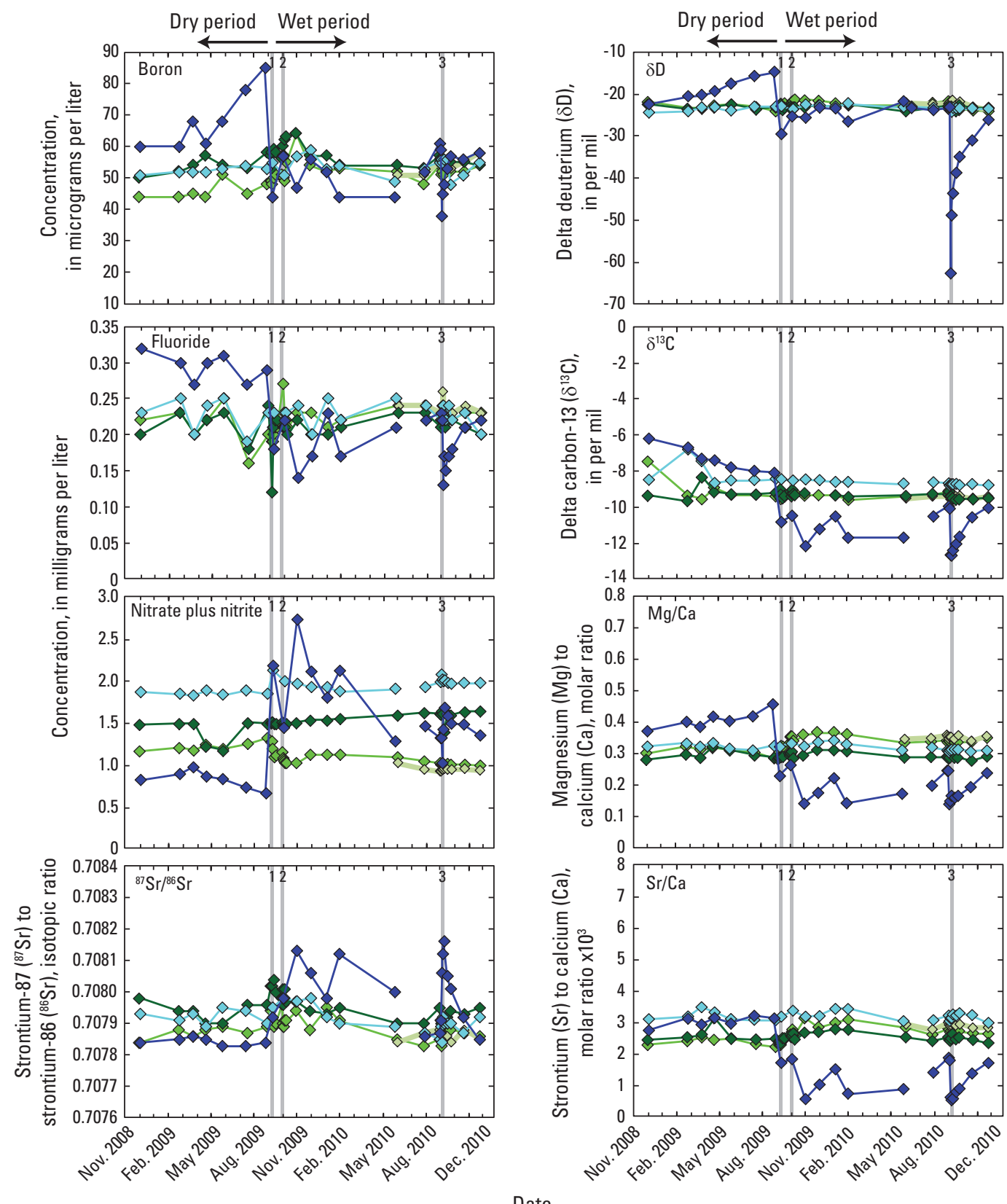
EXPLANATION
| Onset of major storm and identifier
Spring, by orifice
(table 1)—Sample
$\rightarrow \quad$ Deep Spring
$\approx$ Diversion Spring
$\diamond$ Weissmuller Spring
$\diamond \quad$ Comal Spring 1
$\rightarrow \quad$ Hueco Spring A
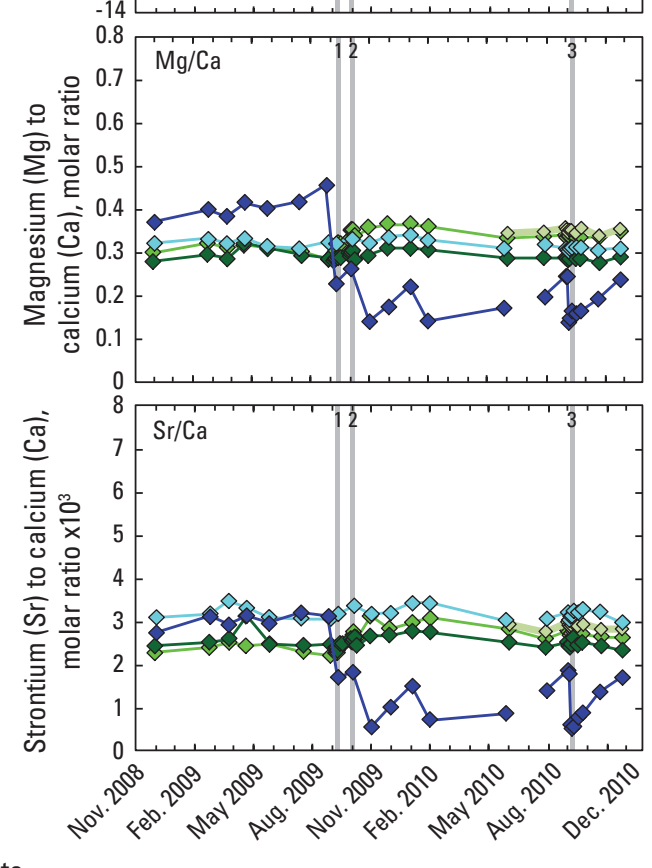

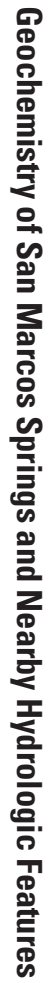

Figure 18. Time series (November 2008-December 2010) of selected physicochemical properties and geochemical constituents for Edwards aquifer springs sampled for the characterization of San Marcos Springs, south-central Texas.-Continued 
The low $\mathrm{NO}_{3}+\mathrm{NO}_{2}$ concentrations and lower dissolved oxygen concentrations relative to the other Edwards aquifer wells indicate that groundwater from the Aqua well likely includes a component of reduced water. Strontium concentrations for the Aqua well (median of $41,900 \mu \mathrm{g} / \mathrm{L}$ ) were particularly high relative to the other Edwards aquifer wells, as well as to the median value for samples from regional confined wells (median of $540 \mu \mathrm{g} / \mathrm{L}$; Musgrove and others, 2010). Oetting (1995) identified examples of groundwater from the Edwards aquifer with high $\mathrm{Sr}$ concentrations in a narrow "transition" zone near the downdip limit of the aquifer and proposed that water-rock interaction with Sr-rich minerals such as celestite or strontianite along fault contacts between Edwards aquifer and Trinity aquifer carbonates might account for these transitional compositions. The $\mathrm{Sr}$ composition of the Aqua well cannot be solely accounted for by mixing between Edwards aquifer fresh and saline-zone groundwater. The composition of well LR-58-58-403 (Buda well) has also been proposed to be consistent with Oetting's (1995) description of transitional water (Mahler and others, 2011).

During the dry period, numerous geochemical constituents for well LR-67-01-403 (hereinafter, Solar well) were distinct from the other Edwards aquifer wells $(\mathrm{Mg}, \mathrm{Sr}$, $\mathrm{Na}, \mathrm{Cl}, \mathrm{SO}_{4}, \mathrm{~B}, \mathrm{~F}$, and $\mathrm{NO}_{3}+\mathrm{NO}_{2}$ concentrations; $\mathrm{Mg} / \mathrm{Ca}$ and $\mathrm{Sr} / \mathrm{Ca}$ ratios, ${ }^{87} \mathrm{Sr} r{ }^{86} \mathrm{Sr}, \delta \mathrm{D}$, and $\delta^{13} \mathrm{C}$ isotopic compositions) (table 5; fig. 15). With the exception of the Solar well, the Edwards aquifer wells showed little variability from the dry period to the wet period (table 5; fig. 15), indicating that groundwater from these wells was largely not affected by changes in hydrologic conditions and, thus, likely not influenced by local recharge sources or conduit flow paths. At the Solar well, however, numerous geochemical constituents changed markedly at the beginning of the wet period (fig. 15), indicating that groundwater from this well was affected by mixing with a more saline groundwater source and (or) the influence of different geochemical processes. Toward the latter part of the wet period, starting around May 2010, the geochemical composition of the Solar well returned to a composition similar to that observed during the dry period (fig. 15). The $\mathrm{SO}_{4} / \mathrm{Cl}$ ratio at the Solar well also changed significantly (increased) from the dry period to wet period, whereas $\mathrm{SO}_{4} / \mathrm{Cl}$ ratios in the other Edwards wells decreased (table 5). Previous studies have indicated that Trinity aquifer groundwater is characterized by higher $\mathrm{SO}_{4} / \mathrm{Cl}$ ratios than is Edwards aquifer saline-zone groundwater (Sharp and Clement, 1988; Garner and Mahler, 2007; Musgrove and others, 2010). The increase in $\mathrm{SO}_{4} / \mathrm{Cl}$ ratios in the Solar well at the onset of the wet period, accompanied by increases in ion concentrations (fig. 15), might be indicative of mixing with Trinity aquifer groundwater.

\section{Trinity Aquifer}

Selected geochemical data for routine samples collected from the three Trinity aquifer wells (fig. 1, including Ruby Ranch) are shown in figure 16; summary statistics are shown in table 5. The Trinity aquifer wells exhibited differences in their geochemistry that, similar to the Edwards aquifer wells, likely reflect different flow paths and, consequently, different water sources or different amounts of water-rock interaction. Groundwater from the Trinity aquifer is spatially variable and generally more mineralized than that from the Edwards aquifer (Fahlquist and Ardis, 2004). Nonetheless, $\mathrm{Cl}$ concentrations and specific conductance values for samples collected from the Trinity aquifer wells were generally similar to those for samples collected from the Edwards aquifer wells (table 5), indicating that the Trinity aquifer wells were likely sourced from relatively fresh parts of the Trinity aquifer. Strontium concentrations were generally higher for the Trinity aquifer wells than for the Edwards aquifer wells (with the exception of the Aqua well) (table 5). Most geochemical constituents did not change significantly from the dry period to the wet period at the Trinity aquifer wells (table 5), indicating that groundwater from these wells was largely not affected by changes in hydrologic conditions or dilute surface-water recharge.

\section{Springwater}

Selected geochemical data for routine water-quality samples collected from San Marcos Springs (Deep, Diversion, and Weissmuller Springs), Comal Spring 1, and Hueco Spring $A$ are shown in figure 18. Summary statistics are shown in table 5. The geochemistry of Comal Spring 1 varied little from the dry period to the wet period (table 5; fig. 18), indicating that Comal Springs is not generally responsive to local recharge sources. These results are consistent with previous studies that have proposed that Comal Springs is largely supplied by regional flow paths originating in the western parts of the aquifer (Puente, 1976; Guyton and Associates, 1979; LBG-Guyton Associates, 2004; Johnson and Schindel, 2008). Samples collected from Comal Spring 1 exhibit some differences in chemical composition compared to samples collected from San Marcos Springs, notably lower specific conductance values, higher water temperature, and higher $\mathrm{Sr}$ and $\mathrm{NO}_{3}+\mathrm{NO}_{2}$ concentrations (table 5; fig. 18). In contrast to the geochemistry of samples collected from Comal Spring 1, the geochemistry of samples collected at Hueco Spring A was quite variable; the majority of selected constituents (19 of 28 physicochemical and geochemical) were significantly different during the dry period than during the wet period (table 5). Concentrations of some constituents decreased immediately following the onset of the wet period 
(for example, $\mathrm{Mg}, \mathrm{Sr}, \mathrm{Na}, \mathrm{SO}_{4}, \mathrm{~B}$, and F), likely reflecting rapid dilution by recharging surface water. These results indicate that Hueco Springs is very responsive to changes in hydrologic conditions and is strongly influenced by local recharge sources. Higher turbidity values and lower concentrations of most major ions from the dry period to the wet period are consistent with dilution by recently recharged surface water.

The two orifices of San Marcos Springs that were sampled during both the dry and wet periods (Deep and Diversion Springs) showed different responses to changes in hydrologic conditions. At Deep Spring, similar to Comal Spring 1, few geochemical constituents changed significantly from the dry period to the wet period (table 5; fig. 18), indicating that Deep Spring is likely not influenced by local recharge sources. In contrast, results for Diversion Spring indicate that it was more responsive to changes in hydrologic conditions ( 16 of 28 selected physicochemical and geochemical constituents changed significantly from the dry period to the wet period). The number of constituents that varied significantly from the dry period to the wet period was similar to that for Hueco Spring A, although the geochemical variability at Diversion Spring was more muted than at Hueco Spring A, with smaller changes in most geochemical constituents (table 5). These results indicate that Diversion Spring is subject to more variability in recharge sources or flow paths than are Comal Springs or Deep Spring. The changes in geochemical constituents that occurred at Diversion Spring from the dry period to the wet period, however, are not consistent with dilution from recently recharged surface water; significantly higher median concentrations of $\mathrm{Mg}, \mathrm{Sr}, \mathrm{Cl}$, $\mathrm{SO}_{4}$, potassium $(\mathrm{K}), \mathrm{B}$, and $\mathrm{Br}$ during the wet period indicate that Diversion Spring was likely influenced by a more saline groundwater source. Samples were collected at Weissmuller Spring only during the wet period; thus, changes in chemical composition from the dry period to the wet period could not be compared. The chemical composition of Weissmuller Spring during the wet period was similar to that of Diversion Spring (table 5; fig. 18).

\section{Geochemical Variability in Response to Storms}

Samples were collected at stream and spring sites in response to three major storms (storms 1-3; table 3) during the wet period. A series of samples was collected for all three storms from Deep and Diversion Springs. A single sample was collected from Comal Spring 1 and Hueco Spring A for storms 1 and 2. For storm 3, a series of six samples were collected from Deep, Diversion, Weissmuller, Comal Spring 1, and Hueco Spring A. Samples were collected from streams in response to storms 1-3 depending on flow. No groundwater (well) samples were collected in response to storms. The three major storms evaluated for this investigation varied in size, antecedent moisture conditions, and resulting stream and spring response (table 3; fig. 6). In addition to the three sampled storms, other storms during the study affected stream and spring discharge and estimated aquifer recharge (table 4).

\section{Surface Water}

Rapid increases in stream discharge occurred in response to storms 1-3 (fig. 6). At Blanco at Halifax, most increases in discharge were accompanied by rapid decreases in specific conductance and rapid increases in turbidity (figs. 11 and 13). Specific conductance values decreased by more than $100 \mu \mathrm{S} /$ $\mathrm{cm}$ in response to storms 1 and 3 and by a lesser amount $(20 \mu \mathrm{S} / \mathrm{cm})$ in response to storm 2 , possibly because the stream had not recovered from storm 1; also, storm 2 was a smaller storm with wetter antecedent conditions. Increases in turbidity values were greater than 1,000 FNU for both storms 1 and 3 (no turbidity data were recorded for storm 2).

Samples were collected from the Blanco at Halifax, Blanco near Kyle, Guadalupe at River Road, Cibolo Creek, Sink Creek, and Purgatory Creek sites in response to storms 1-3 depending on flow (fig. 13); samples were collected from the Guadalupe River for storms 1 and 2, from Sink Creek for storms 2 and 3, and from Purgatory Creek for storm 3. Geochemical variability in samples from the stream sites was largest in response to storms 1 and 3 (fig. 13). For storm 1, which marked the transition from the dry period to the wet period, geochemical changes likely were larger because of the effect of prolonged dry antecedent conditions associated with the preceding drought. For storm 3, geochemical changes likely were larger as a result of storm characteristics: storm 3 (tropical storm Hermine) was the largest storm to occur during the study period (table 3). Storm 3 resulted in the largest stream discharge increase for Blanco at Halifax and was the only storm event during the study period for which both Sink and Purgatory Creeks flowed. Storm 3, which is likely representative of similar large storms, resulted in substantial dilution of prestorm streamflow with the increased proportion of rainfall and runoff to the stream. Both storms 1 and 3 likely resulted in dilution of prestorm streamflow as indicated by the rapid decrease in specific conductance at Blanco at Halifax and relatively low concentrations of numerous geochemical constituents, including $\mathrm{Mg}, \mathrm{Sr}, \mathrm{Na}, \mathrm{Cl}, \mathrm{SO}_{4}, \mathrm{Br}, \mathrm{B}$, and $\mathrm{F}$ in the stream samples collected in response to storms relative to nonstorm (routine) samples (fig. 13). Because Cibolo Creek, Sink Creek, and Purgatory Creek only flowed in the study area in response to storms, there are no nonstorm water-quality data for comparison; however, concentrations of geochemical constituents measured in storm samples collected from these streams were generally low compared to those measured in routine samples from other stream sites (fig. 12). 


\section{Springwater}

At Comal Spring 1, few changes in geochemistry were observed in response to storms 1-3 (fig. 13). For storm 1, the most notable difference when comparing the sample collected prior to the storm to the sample collected in response to the storm was a $0.28-\mathrm{mg} / \mathrm{L}$ increase in $\mathrm{NO}_{3}+\mathrm{NO}_{2}$ concentration. In response to storm 3 , for which a series of samples were collected from Comal Spring 1, the geochemistry of spring discharge did not change substantially. These results are consistent with the hypothesis that Comal Springs is predominantly supplied by regional flow paths and not affected by local recharge. In contrast to Comal Spring 1, substantial changes in geochemistry in response to storms were observed at Hueco Spring A (fig. 13). For storm 1, comparing results for the sample collected prior to and in response to the storm, specific conductance decreased 102 $\mu \mathrm{S} / \mathrm{cm}$, turbidity increased $109 \mathrm{FNU}$, and dissolved oxygen concentrations increased by $3 \mathrm{mg} / \mathrm{L} ; \mathrm{Mg}, \mathrm{Sr}, \mathrm{Na}, \mathrm{Cl}, \mathrm{SO}_{4}, \mathrm{Br}$, $\mathrm{B}$, and $\mathrm{F}$ concentrations decreased substantially, the $\mathrm{NO}_{3}+\mathrm{NO}_{2}$ concentration increased, and isotopic compositions also varied. These changes are indicative of dilution with recent surface-water recharge. Similar, although generally larger in magnitude, geochemical changes were observed at Hueco Spring A in response to storm 3, with a notable response in spring geochemistry occurring within 2 days. In contrast with storm 1, $\mathrm{NO}_{3}+\mathrm{NO}_{2}$ concentrations at Hueco Spring A in response to storm 3 initially decreased then subsequently increased. Within several days subsequent to storm 3, most geochemical constituents at Hueco Springs had begun to return to prestorm values.

The response to storms at San Marcos Springs was more similar to Comal Springs than to Hueco Springs. Spring discharge increased at Comal, Hueco, and San Marcos Springs in response to storms 1-3 (fig. 6; table 3), as well as in response to unsampled storms that occurred during the study period (table 4). While spring discharge increased at Comal Springs and San Marcos Springs in response to storms $1-3$, the rate of increase was generally more muted and gradual than at Hueco Springs, consistent with a response to regional hydrologic conditions and predominantly regional recharge sources. Continuous recording of physicochemical properties at San Marcos Springs provided the opportunity to evaluate the response to numerous storm events in addition to storms 1-3; few changes were observed in physicochemical properties in response to storms 1-3 (fig. 13) or other storms (fig. 19) that occurred during the study period. Changes in specific conductance or turbidity that occurred at Deep, Diversion, or Weissmuller Springs in response to storms were generally small and inconsistent (for example, in response to some storms, specific conductance increased slightly at Deep and Diversion Springs). Similarly, few geochemical changes were observed at San Marcos Springs orifices in response to storms 1-3 (fig. 13); some variability was observed in $\mathrm{Br}$ and $\mathrm{F}$ concentrations in response to storms 1 and 2. In response to storm 3, dissolved oxygen concentrations at both Deep and Diversion Springs varied, with an initial increase and then decrease in concentration. Time-series water-quality data for Weissmuller Spring in response to storm 3 showed little variability (fig. 13).

\section{Interaction Between Surface Water and Groundwater}

Karst aquifers are characterized by extensive surfacewater and groundwater interaction. In the Edwards aquifer, recharge predominantly occurs by way of losing streams that provide direct interaction between surface water and groundwater (Sharp and Banner, 1997). Recharge sources to karst aquifers can vary as a result of seasonal changes, as well as individual storm events, and are reflected in corresponding changes in spring geochemistry (White, 1988; Ford and Williams, 2007). Previous studies in the San Antonio and Barton Springs segments of the Edwards aquifer have documented extensive surface-water/groundwater interaction and corresponding variability in geochemistry in response to changes in recharge and hydrologic conditions (Mahler and others, 2006; Garner and Mahler, 2007; Massei and others, 2007; Musgrove and others, 2010; Mahler and others, 2011). Because recent recharge is typically geochemically distinct from groundwater, chemical mixing models using constituents such as specific conductance, isotopic compositions, major ion and (or) contaminant concentrations, and carbonate mineral saturation indices are often useful for distinguishing the proportion of recent recharge (quick flow) in karst groundwater and spring discharge (for example, Scanlon and Thrailkill, 1987; Lakey and Krothe, 1996; Pinault and others, 2001; Vesper and White, 2004; Mahler and Massei, 2007; Mahler and Garner, 2009). Variations in geochemistry at San Marcos Springs were used to distinguish potential sources of spring discharge, specifically mixing between potential endmembers: local sources such as recently recharged surface water (quick flow) from the Blanco River and regional aquifer sources such as matrix-flow groundwater (slow flow). Mixing with a more saline groundwater source, specifically from the saline zone or the Trinity aquifer, was also considered. Routine sample conditions during the dry and wet periods, as well as the response to storms, were evaluated.

\section{Specific Conductance and Spring Discharge}

Variations in specific conductance in karst groundwater and springwater are often interpreted to reflect varying contributions of different water masses with different compositions moving through the aquifer (such as recent recharge and water in storage in the aquifer) (White, 1999). Rainfall has very low specific conductance (Herczeg and Edmunds, 2000). In surface-water systems, specific conductance and associated major-ion concentrations generally decrease with increasing discharge, largely as a result of dilution by rainfall runoff (Hem, 1989). Likewise, 

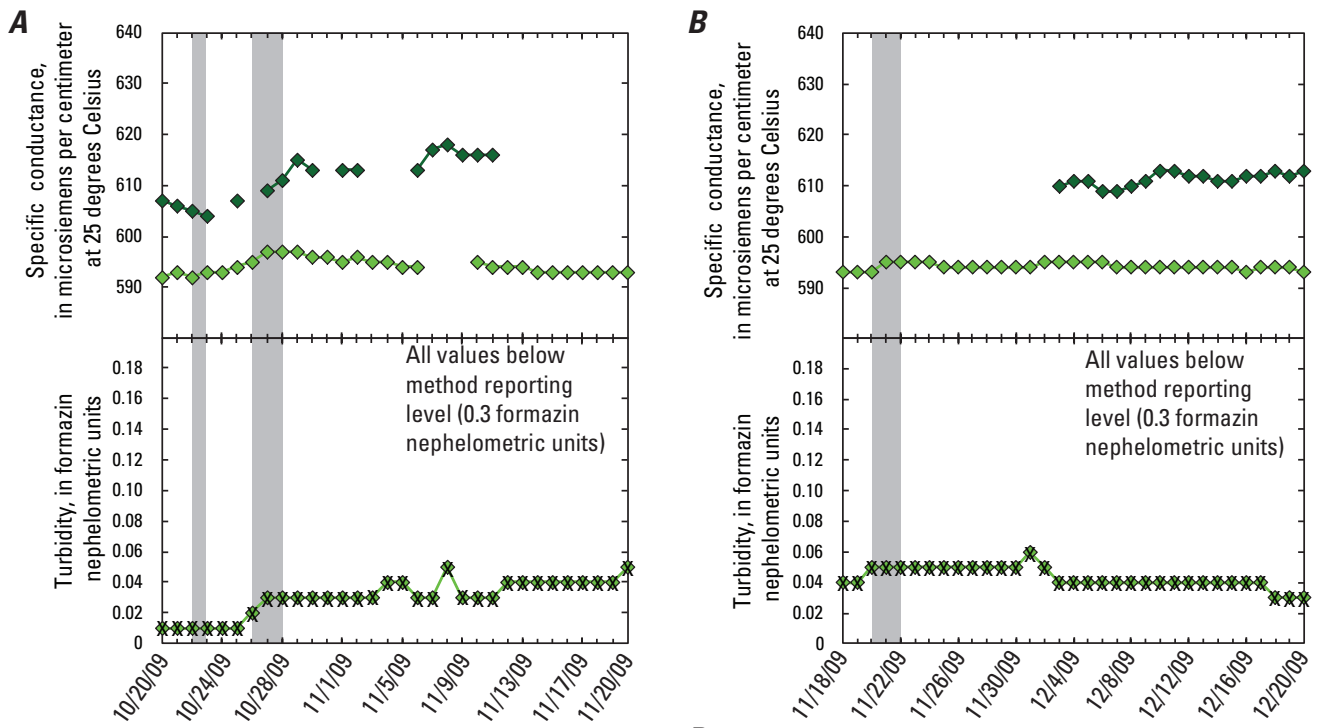

EXPLANATION
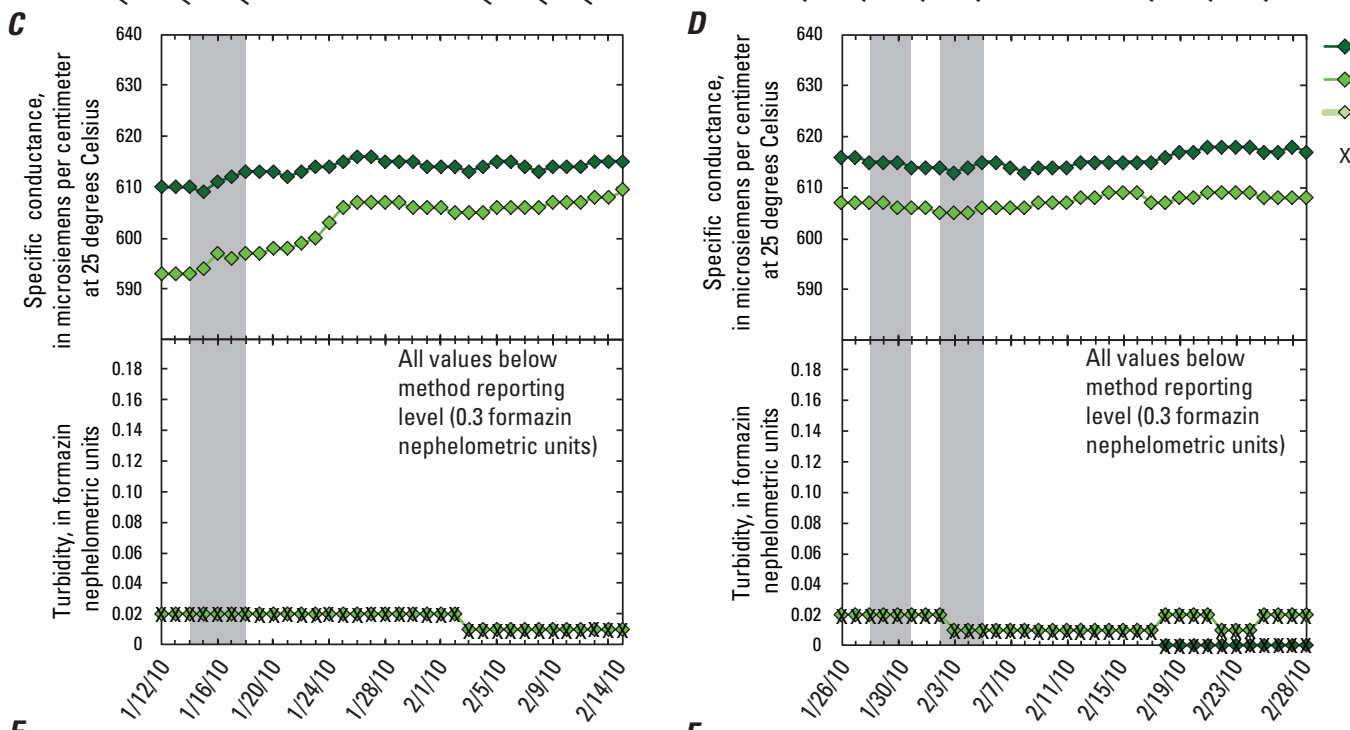

Time period of rainfall associated with storm

Spring, by orifice (table 1)

E

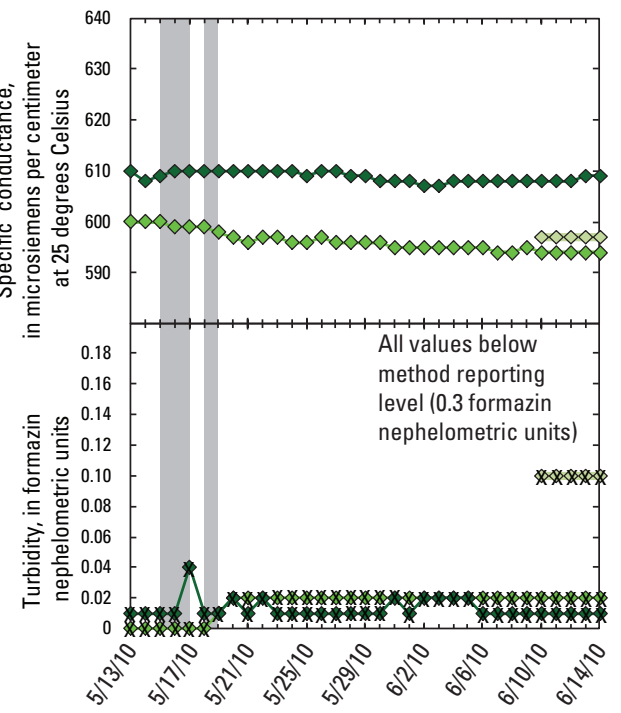

$\boldsymbol{F}$

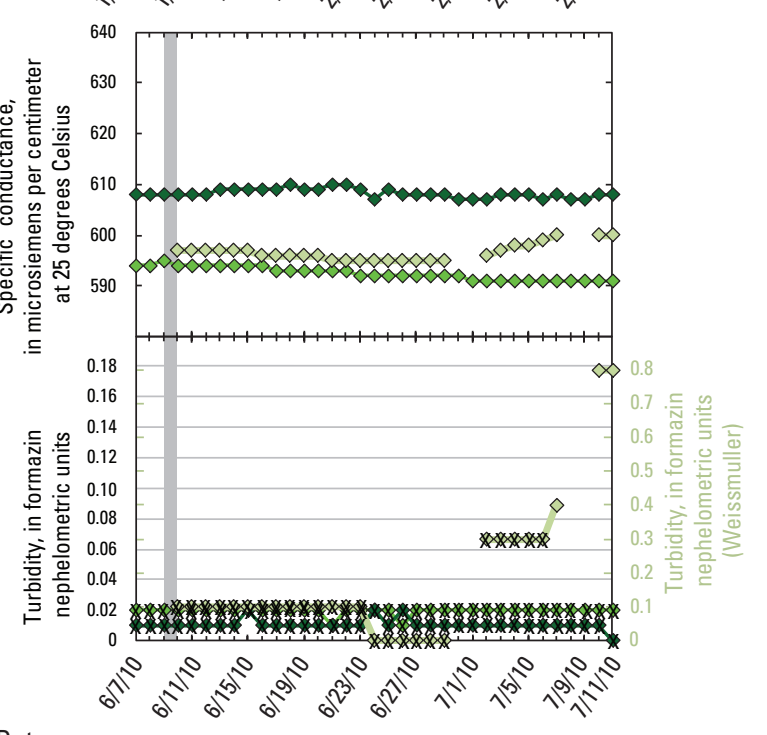

Figure 19. Times series (November 2008-December 2010) of specific conductance and turbidity values at San Marcos Springs orifices (Deep, Diversion, and Weissmuller Springs), south-central Texas, preceding and in response to unsampled storms. A, Storm onset October 22, 2009. B, Storm onset November 20, 2009. C, Storm onset January 14, 2010. D, Storm onset January 28, 2010. E, Storm onset May 15, 2010. F, Storm onset June 9, 2010. 
specific conductance of groundwater can act as a tracer of recently infiltrated runoff and associated surface water that recharges a karst aquifer (for example, Scanlon and Thrailkill, 1987; Desmarais and Rojstaczer, 2002; Massei and others, 2007). In response to rain and recharge events, karst springs and groundwater wells that are affected by focused recharge generally show a rapid decrease in specific conductance, followed by a gradual increase to a value more representative of interaction with the aquifer matrix (Garner and Mahler, 2007). In the Edwards aquifer, this process is well documented: at Barton Springs, for example, a decrease in specific conductance is typically observed less than a day after the onset of rainfall and recharge (City of Austin, 1997; Mahler and others, 2006, 2011), and similar responses have been documented at groundwater wells affected by focused recharge and conduit flow (Garner and Mahler, 2007).

Results of this study indicate that, similar to Barton Springs, Hueco Springs is affected by a large component of focused recharge, with a rapid decrease in specific conductance and large changes in other geochemical constituents occurring in response to recharge events (for example, storms 1 and 3) (figs. 13 and 18). In contrast, changes in specific conductance at Comal Springs were small during the study period (within a range of $27 \mu \mathrm{S} / \mathrm{cm}$, or about 5 percent) and showed little variability from the dry period to the wet period (fig. 18) or in response to storms (fig. 13). The lack of variability in specific conductance at Comal Springs is consistent with the interpretation that Comal Springs discharge is supplied largely by regional groundwater flow paths and is not affected appreciably by local recharge sources.

Specific conductance values at San Marcos Springs (Deep and Diversion) varied during the study period within a range of about $40 \mu \mathrm{S} / \mathrm{cm}$ (fig. 18), intermediate to that for Hueco and Comal Springs (because Weissmuller was monitored for a shorter period only during the wet period, this discussion is focused on Deep and Diversion Springs at San Marcos Springs). Specific conductance at Deep and Diversion Springs did not consistently change in response to storms 1-3 (fig. 13) or in response to other rain events (fig. 19) and generally did not show rapid changes indicative of the effect of dilution by recent recharge. Variability in specific conductance at San Marcos Springs occurred during longer periods such as months, which is not indicative of recharge from individual rainfall and recharge events; rather, specific conductance variability seems to reflect a complex relation with spring discharge (fig. 20) that departs from the typical conceptual understanding of karst aquifers. For example, specific conductance at Diversion Spring decreased initially at the start of the wet period and then remained relatively constant for several months until January 2010 (fig. 20). In January 2010 specific conductance increased at both Deep and Diversion Springs, following a similar pattern at the two orifices, then leveled off, and then decreased through spring 2010. Specificconductance values at Deep and Diversion Springs had a similar rise and subsequent drop during summer 2009 (in the dry period, when little to no recharge was occurring) (fig. 20).
The relation between specific conductance and discharge for a karst spring for which discharge is dominated by a continuum between two endmembers of quick flow and slow flow would likely be characterized by an inverse relation, where specific conductance generally decreases with increased discharge, reflecting a larger component of quick flow at higher discharge values. The relation between specific conductance and discharge at San Marcos Springs indicates that additional water sources contribute to spring discharge. Specific conductance generally decreased with increasing discharge for low discharge conditions $\left(<100 \mathrm{ft}^{3} / \mathrm{s}\right)$; at around $150 \mathrm{ft}^{3} / \mathrm{s}$, however, a change in slope occurred, and specific conductance increased with discharge for higher discharge values (fig. 20). This increase in specific conductance with higher discharge values of more than $150 \mathrm{ft}^{3} / \mathrm{s}$ was significant for all three monitored orifices (Kendall's tau of $0.51,0.51$, and 0.41 for Diversion, Weissmuller, and Deep Springs, respectively) and is consistent with an increase in more saline water contributing to San Marcos Springs. These relations between discharge and specific conductance (fig. 20) indicate that San Marcos Springs likely is affected by a variable mixture of water sources contributing to spring discharge that vary depending on hydrologic conditions, and that the contribution of more saline groundwater increased at higher discharge values of more than about $150 \mathrm{ft}^{3} / \mathrm{s}$.

\section{Tracers of Geochemical Evolution Processes}

Geochemical evolution processes that occur as a result of interactive processes between water and rock in carbonate aquifers provide insight into groundwater residence time and flow paths, diffuse and conduit recharge sources, mineralsolution reactions, and mixing processes. Previous work in the Edwards aquifer provides a framework of understanding for geochemical evolution processes that affect geochemical and isotopic tracers such as $\mathrm{Mg} / \mathrm{Ca}$ and $\mathrm{Sr} / \mathrm{Ca}$ ratios and $\mathrm{Sr}$ isotopes (for example, Oetting, 1995; Sharp and Banner, 1997; Musgrove and Banner, 2004; Wong and others, 2011; Musgrove and others, 2010). As discussed in Musgrove and others (2010), $\mathrm{Mg} / \mathrm{Ca}$ and $\mathrm{Sr} / \mathrm{Ca}$ ratios in carbonate groundwater typically increase along flow paths as a result of water-rock interaction and progressive groundwater evolution processes (for example, calcite recrystallization, incongruent dolomite dissolution, and prior precipitation of calcite along flow paths) (Plummer, 1977; Trudgill and others, 1980; Lohmann, 1988; Fairchild and others, 2000; Musgrove and Banner, 2004). Higher $\mathrm{Mg} / \mathrm{Ca}$ and $\mathrm{Sr} / \mathrm{Ca}$ ratios are consistent with longer residence times and greater extents of mineralsolution reaction. Strontium isotope ratios $\left({ }^{87} \mathrm{Sr} /{ }^{86} \mathrm{Sr}\right)$ in the Edwards aquifer have been applied in conjunction with $\mathrm{Mg}$ / $\mathrm{Ca}$ and $\mathrm{Sr} / \mathrm{Ca}$ ratios as tracers of water-rock interaction, groundwater residence time, recharge, and the influence of soil composition on groundwater geochemistry (Oetting and others, 1996; Musgrove and Banner, 2004; Garner, 2005; Wong and others, 2011). As demonstrated in these studies, $\mathrm{Sr}$ 

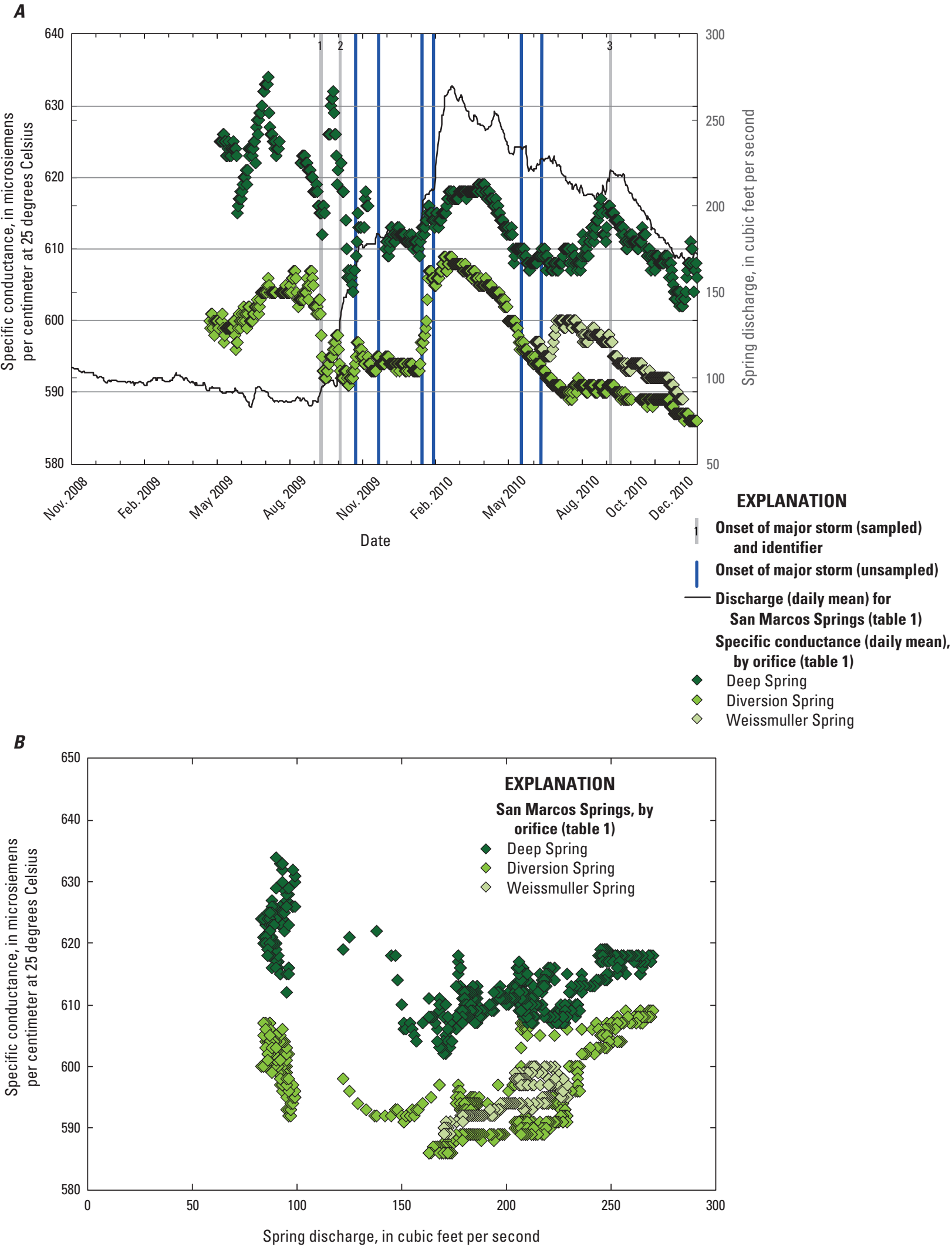

Figure 20. Specific conductance at San Marcos Springs, south-central Texas. A, Time series (November 2008-December 2010) of specific conductance for Deep, Diversion, and Weissmuller Springs orifices, and discharge at San Marcos Springs. B, Relation of specific conductance (Deep, Diversion, and Weissmuller Springs orifices) with discharge at San Marcos Springs. 
isotope ratios in the Edwards aquifer generally decrease with increasing water-rock interaction, approaching values similar to those of the Cretaceous-age limestone aquifer rocks, which have values ranging from 0.7074 to 0.7077 (Koepnick and others, 1985; Oetting, 1995). Higher ${ }^{87} \mathrm{Sr} /{ }^{86} \mathrm{Sr}$ values for groundwater relative to the aquifer rocks are indicative of a source of more radiogenic $\mathrm{Sr}$ (enriched in ${ }^{87} \mathrm{Sr}$ ) to the groundwater, which has been previously proposed to result from chemical interaction with overlying soils (Musgrove and Banner, 2004). Lower ${ }^{87} \mathrm{Sr} /{ }^{86} \mathrm{Sr}$ values are indicative of proportionally more interaction with limestone aquifer rocks as a result of longer groundwater residence time. At a local scale, variations in limestone composition, soil composition, flow paths, and residence time can affect individual values of these geochemical constituents.

Variations in $\mathrm{Mg} / \mathrm{Ca}$ and $\mathrm{Sr} / \mathrm{Ca}$ ratios and $\mathrm{Sr}$ isotope values for the springs were evaluated to distinguish potential differences in residence time, flow paths, and components of diffuse versus conduit flow affecting the springs. Results for Hueco Springs were consistent with marked changes in recharge sources from the dry period to the wet period. Values for these constituents at Hueco Spring A were significantly different between the dry and wet periods and covered a larger range than at Comal Spring 1 or San Marcos Springs (table 5); lower $\mathrm{Mg} / \mathrm{Ca}$ and $\mathrm{Sr} / \mathrm{Ca}$ ratios and higher $\mathrm{Sr}$ isotope values during the wet period are consistent with a large component of recently recharged, less geochemically evolved water contributing to Hueco Springs (fig. 21). In contrast with Hueco Spring $\mathrm{A}, \mathrm{Mg} / \mathrm{Ca}$ and $\mathrm{Sr} / \mathrm{Ca}$ ratios and ${ }^{87} \mathrm{Sr} /{ }^{86} \mathrm{Sr}$ values at Comal Spring 1 and at Deep Spring were not significantly different between the dry and wet periods (table 5; fig. 21). At Diversion Spring, $\mathrm{Mg} / \mathrm{Ca}$ and $\mathrm{Sr} / \mathrm{Ca}$ ratios were significantly different between the dry period and wet period (table 5) but covered a small range of values relative to Hueco Spring A; ${ }^{87} \mathrm{Sr} /{ }^{86} \mathrm{Sr}$ values at Diversion Spring were not significantly different between the dry and wet periods (table 5). Ratios of $\mathrm{Mg} / \mathrm{Ca}$ and $\mathrm{Sr} / \mathrm{Ca}$ at Diversion Spring during the dry period were similar to values at Deep Spring; during the wet period, $\mathrm{Mg} / \mathrm{Ca}$ and $\mathrm{Sr} / \mathrm{Ca}$ ratios at Diversion Spring shifted to higher values relative to the dry period (table 5; fig. 21). This shift in $\mathrm{Mg} / \mathrm{Ca}$ and $\mathrm{Sr} / \mathrm{Ca}$ values during the wet period is consistent with a change in the proportion of different water sources contributing to Diversion Spring: the shift is consistent with an increased contribution of more geochemically evolved, longer residence time groundwater, rather than recent recharge, such as is observed at Hueco Springs. Results for Weissmuller Spring for $\mathrm{Mg} / \mathrm{Ca}$ and $\mathrm{Sr} / \mathrm{Ca}$ ratios and ${ }^{87} \mathrm{Sr} /{ }^{86} \mathrm{Sr}$ values (collected during only the wet period) are similar to those for Diversion Spring during the wet period (table 5; fig. 21) and imply a similar origin and similar flow paths for water supplying both Diversion and Weissmuller Springs. These results indicate that discharge sources to Diversion Spring changed from the dry period to the wet period, whereas discharge sources to Deep Spring were more constant.

\section{Endmember Mixing Using PHREEQC}

Results of inverse modeling with the geochemical model PHREEQC (Parkhurst and Appelo, 1999) (table 6) provide insight into interactions between surface water and groundwater, aquifer processes under different hydrologic conditions, mixing, and potential sources of discharge from San Marcos Springs. Model results approximate mixing proportions of designated source (endmember) water compositions (regional groundwater flow, local stream recharge, saline-zone groundwater, and Trinity aquifer groundwater) and mass-transfer processes along hypothetical flow paths that could feasibly produce the composition of discharge at San Marcos Springs. Inverse modeling was considered for a range of hydrologic conditions (dry, wet, and storm conditions) (fig. 22) and a variety of different endmember combinations. Endmember water compositions used in inverse modeling to account for the composition of San Marcos Springs discharge (specifically Deep, Diversion, or Weissmuller Springs) were as follows:

- Regional groundwater flow: Two endmembers were used to represent Edwards aquifer regional groundwater flow: the composition of Comal Springs discharge (Comal Spring 1) and the composition of groundwater from well $4 \mathrm{D}$, which is located in the Comal Springs Fault Block to the north (downgradient) of Comal Springs (figs. 1 and 2; table 1). Because both compositions were used (that is, both were initial solutions available to the model to include, and the model solutions might include one or both based on specific mass-balance constraints), model solutions included either composition or a mixture of both. Both Comal Springs and well 4D are located upgradient from San Marcos Springs; previous studies have proposed that Comal Springs is largely supplied by regional groundwater flow paths originating in the western parts of the aquifer and that San Marcos Springs is supplied at least in part by the same regional groundwater flow paths (Puente, 1976; Guyton and Associates, 1979; LBG-Guyton Associates, 2004; Johnson and Schindel, 2008). The geochemistry of Comal Springs and well 4D are similar and varied little from the dry period to the wet period (table 5; figs. 15 and 18); the geochemistry of Comal Springs varied little in response to storms that supply local recharge. On the basis of these results, the composition of Comal Springs and well 4D were considered representative of regional groundwater flow.

- Local (stream) recharge: The composition of surface water from the Blanco River was used to represent local recharge.

- Saline-zone groundwater: The saline zone has multiple distinct hydrochemical facies throughout the regional extent of the Edwards aquifer (Clement, 1989; 
$\boldsymbol{A}$

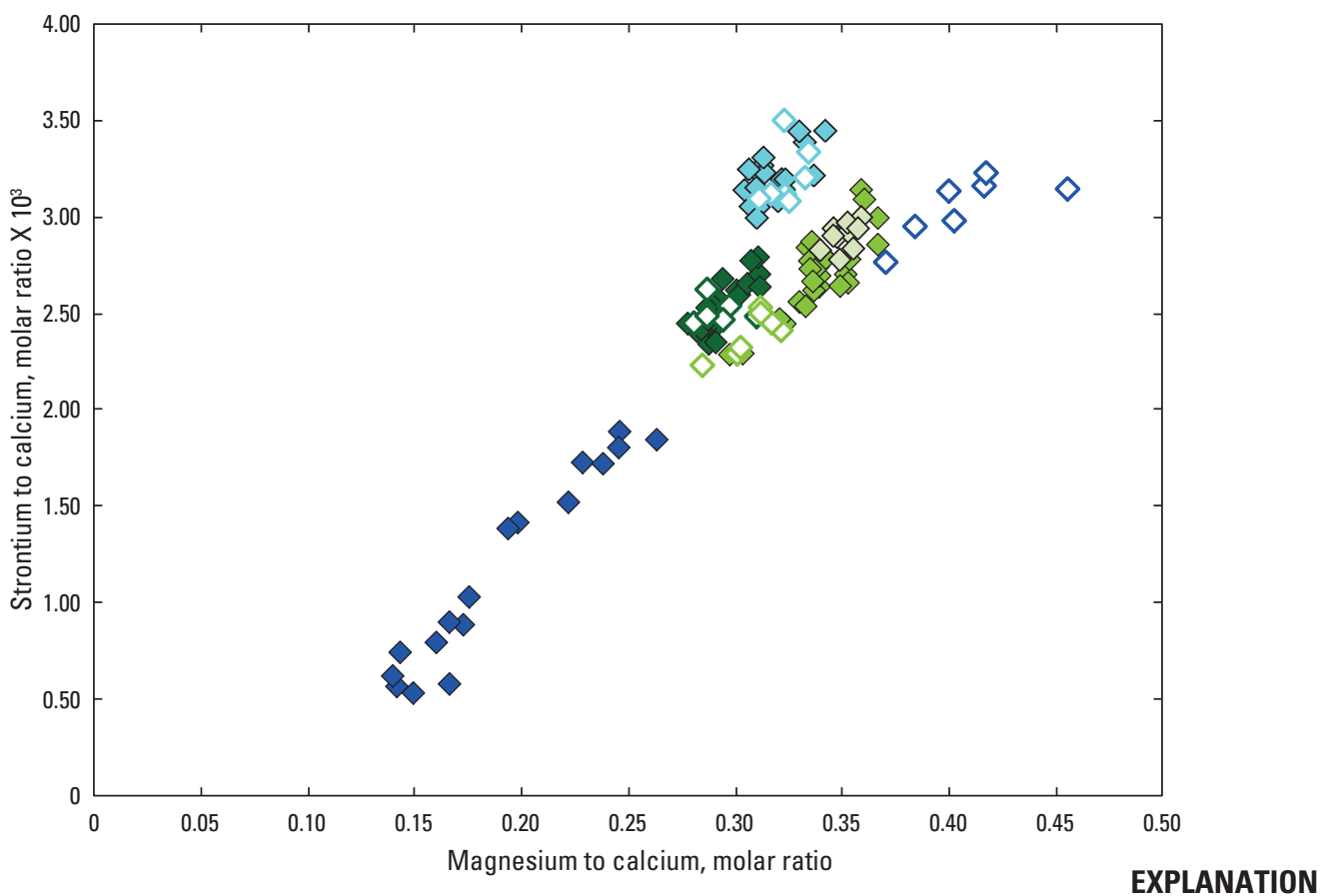

Spring, by orifice (table 1 ) and period

$\diamond$ Deep Spring-Dry period

$\checkmark$ Deep Spring-Wet period

$\diamond$ Diversion Spring-Dry period

$\diamond$ Diversion Spring-Wet period

$\diamond$ Weissmuller Spring-Wet period

$\diamond$ Comal Spring 1-Dry period

$\diamond$ Comal Spring 1-Wet period

$\diamond$ Hueco Spring A-Dry period

B

$\diamond$ Hueco Spring A-Wet period

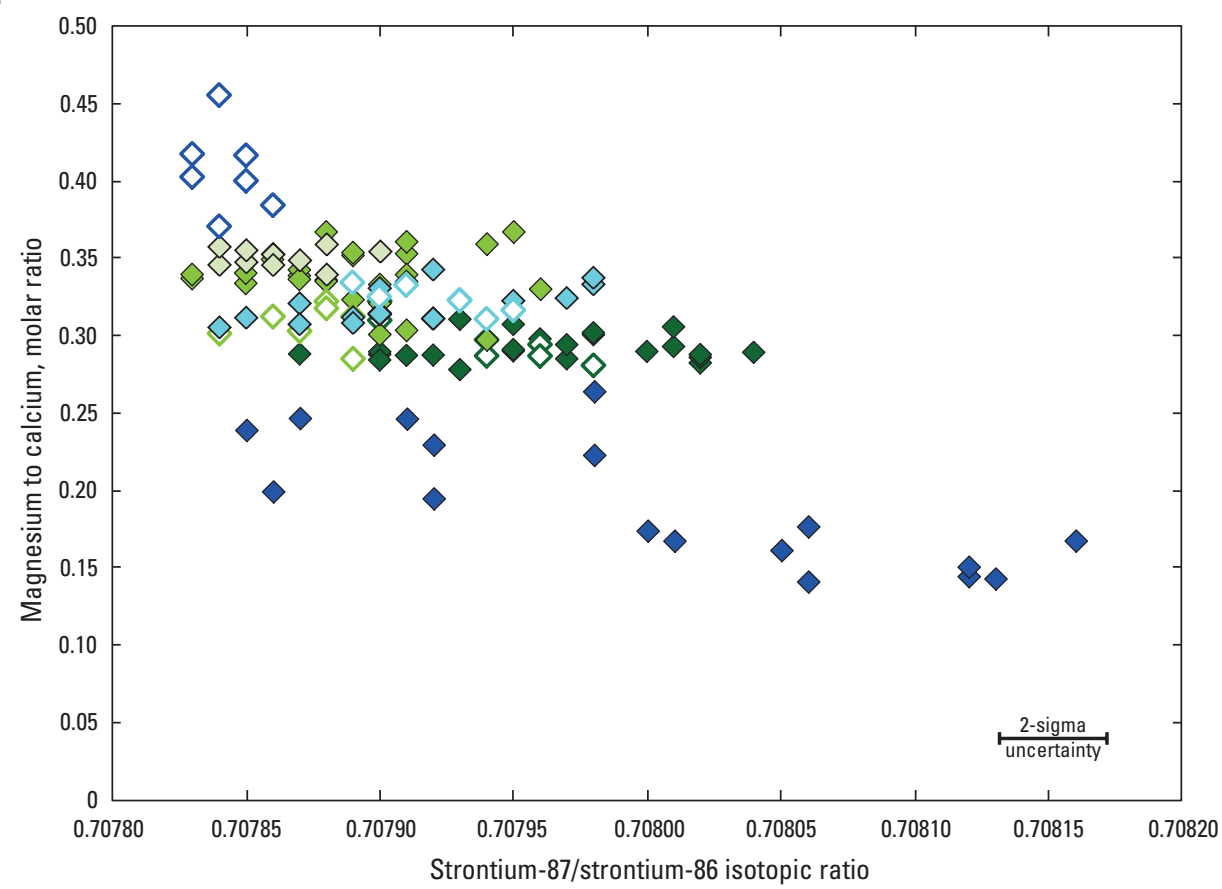

Figure 21. Relations among selected geochemical constituents for samples collected from Comal Spring 1, Hueco Spring A, and San Marcos Springs orifices (Deep, Diversion, and Weissmuller Springs), south-central Texas (November 2008-December 2010). $A$, Magnesium to calcium (molar ratio) and strontium to calcium (molar ratio $\times 10^{3}$ ). $B$, Strontium-87/strontium-86 values and magnesium to calcium (molar ratio); 2-sigma uncertainty is the external error based on analyses of strontium-isotope standard. 


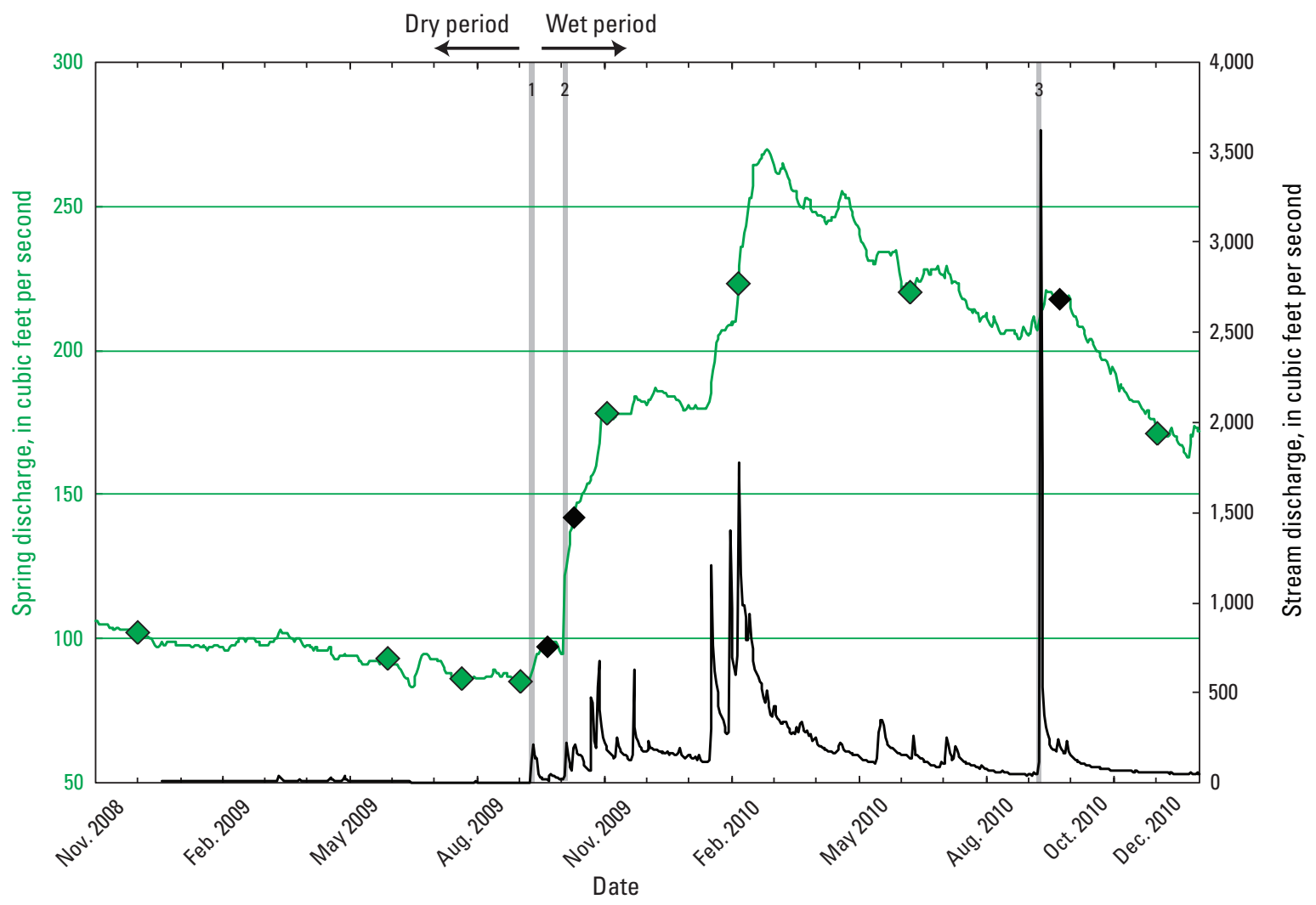

EXPLANATION

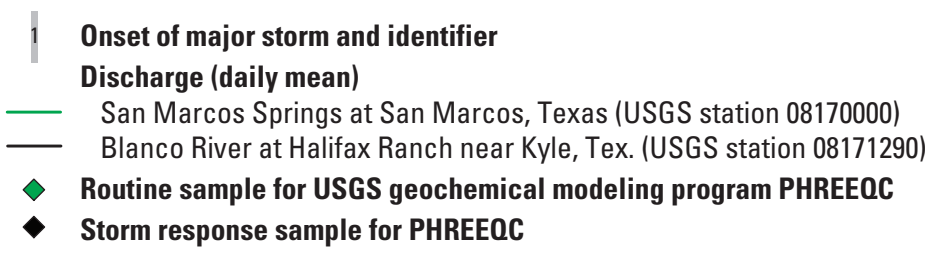

USGS, U.S. Geological Survey

Figure 22. Time series (November 2008-December 2010) of stream discharge for the Blanco River (U.S. Geological Survey station 08171290 Blanco River at Halifax Ranch near Kyle, Texas), spring discharge at San Marcos Springs (U.S. Geological Survey station 08170000 San Marcos Springs at San Marcos, Tex.), and timing of sample collection used for PHREEQC (Parkhurst and Appelo, 1999) geochemical modeling.

Oetting and others, 1996). Several transects of wells across the freshwater/saline-water interface are located within the study area in Hays County (Fish Hatchery, San Marcos, and Kyle transects). The composition of a sample collected from a well in the San Marcos transect in May 2007 (well LR-6701-813A) (Lambert and others, 2009) was used to represent saline-zone groundwater in the vicinity of San Marcos Springs.
- Trinity aquifer groundwater: The composition of groundwater sampled from two Trinity aquifer wells was used to represent the Trinity aquifer: well DX-68-07-505 (hereinafter, Eagle Peak well) in Comal County and well LR-68-08-502 (hereinafter, Burns well) in Hays County (fig. 1; table 1). The Eagle Peak well was sampled for the regional synoptic sampling on December 16, 2008. The Burns well was sampled three times in the dry period between 
December 2008 and March 2009 (the composition of the sample collected on December 29, 2008, was used for inverse modeling). The composition of the Trinity aquifer is spatially variable, and groundwater from the Trinity aquifer is generally more mineralized than that from the Edwards aquifer (Fahlquist and Ardis, 2004). The composition of groundwater from the Eagle Peak well was considered representative of more mineralized Trinity aquifer water in general (labeled "regional/mineralized" in table 6), whereas the composition of groundwater from the Burns well was considered representative of Trinity aquifer water in the vicinity of San Marcos Springs. Both the Eagle Peak well and the Burns well compositions had high specific conductance values and notably high $\mathrm{SO}_{4}$ and $\mathrm{Sr}$ concentrations relative to Edwards aquifer groundwater (Eagle Peak: $797 \mu \mathrm{S} / \mathrm{cm}, 77.7 \mu \mathrm{g} / \mathrm{L} \mathrm{SO}_{4}$, 9,970 $\mu \mathrm{g} / \mathrm{L} \mathrm{Sr}$; Burns: 1,030 $\mu \mathrm{S} / \mathrm{cm}, 214 \mu \mathrm{g} / \mathrm{L} \mathrm{SO}_{4}$, 2,010 $\mu \mathrm{g} / \mathrm{L} \mathrm{Sr}$, respectively) (Crow, 2012). Similar to the regional groundwater flow endmembers, for models including the Trinity aquifer, both Trinity aquifer endmember compositions were used (that is, both were initial solutions available to the model to include, and the model solutions might include one or both based on specific mass-balance constraints), and model solutions included either composition or a mixture of both.

\section{Modeling Associated with Routine Sampling}

Four sampling periods during the dry period were selected for inverse modeling (table 6). During the dry period, little to no surface recharge was occurring; regional groundwater flow endmembers (Comal Springs discharge and groundwater from well 4D) and either the saline-zone groundwater or Trinity aquifer endmembers (groundwater from the Eagle Peak and Burns wells) were mixed to approximate the composition of spring discharge from Deep and Diversion Springs. Separate models included either the saline-zone groundwater endmember or the Trinity aquifer endmembers. Additionally, although little to no surface recharge was occurring, for comparison, all models were also run with a local recharge component (the Blanco River) included in the initial water compositions. Inverse modeling results for the dry period generally indicate that the composition of discharge at both Deep and Diversion Springs is consistent with a dominant component of regional flow that has mixed with a small (up to 0.2 percent) component of saline-zone groundwater. Some models were consistent with mixing of regional groundwater with a small component of Trinity aquifer groundwater (up to 0.6 percent). Some of the models based on mixing of regional and Trinity aquifer groundwater, however, resulted in no plausible model solutions for uncertainties up to 10 percent. Additionally, model uncertainties were typically larger for mixtures that included the Trinity aquifer endmembers relative to those that included the saline-zone groundwater endmember. Thus, model results for the dry period indicate that mixing of regional groundwater flow with a small component of saline-zone groundwater, rather than with a small component of Trinity aquifer groundwater, more likely accounts for the composition of San Marcos Springs. The possibility of mixing with a small component of Trinity aquifer groundwater, however, cannot be eliminated.

Model results consistently indicated that contribution from a more saline water source is necessary to account for the composition of both Deep and Diversion Springs during the dry period. Better constraints on the composition and variability of both saline-zone groundwater and Trinity aquifer groundwater in the vicinity of San Marcos Springs might help distinguish between these two potential sources of saline water to San Marcos Springs. Although little to no local surface recharge was likely occurring during the dry period based on hydrologic conditions, all dry-period models were also run with a local recharge component (the Blanco River) for comparison purposes. For these model runs, the modeled proportion of local recharge ranged from 0 to 25.9 percent, although for most models the local recharge component was low (less than 5 percent). It is hydrologically implausible during the dry period that local recharge could contribute as much as 25.9 percent of spring discharge; for example, for the date with the largest modeled component of local recharge (May 29, 2009), flow in the Blanco River was less than 10 percent of San Marcos Springs discharge. Additionally, geochemical variability during the dry period, for example with respect to stable isotope values, is not consistent with local recharge contributing a discernable component to discharge at San Marcos Springs. A mixture including 25 percent of recharge from the Blanco River (with a $\delta \mathrm{D}$ value on May 28, 2009, of -7.2 per mil [Crow, 2012]) would yield a significant increase in the $\delta \mathrm{D}$ value of spring discharge, on the order of 4 per mil, which is not seen in the isotopic composition of either Deep or Diversion Springs during the dry period (fig. 18). As a result, dry-period model results with a relatively large component of local recharge $(>5 \%)$ are considered hydrologically implausible.

One of the dates during the dry period (September 1, 2009) was modeled with and without $\mathrm{Br}$ as a model-balancing constraint for Deep Spring because a larger uncertainty was needed for the model to balance with $\mathrm{Br}$ included. The $\mathrm{Br}$ concentration at Deep Spring on this date was anomalously high $(0.17 \mathrm{mg} / \mathrm{L})$ relative to other measured $\mathrm{Br}$ concentrations at this site and other San Marcos Springs orifices throughout the study (fig. 18). Higher $\mathrm{Br}$ concentrations are associated with saline-zone groundwater; however, the increase in the $\mathrm{Br}$ concentration on this date was not accompanied by increases in other dissolved constituents (fig. 18) that would also be associated with saline-zone groundwater. Although anthropogenic $\mathrm{Br}$ sources might also be important source in urban areas (Hem, 1989) such as San Marcos, the source of $\mathrm{Br}$ at Deep Spring on this date is unknown. 
Table 6. Summary of PHREEQC (Parkhurst and Appelo, 1999) inverse geochemical modeling results for San Marcos Springs, southcentral Texas (2008-10).

[See table 1 for complete U.S. Geological Survey station names and numbers. $\mathrm{ft}^{3} / \mathrm{s}$, cubic feet per second; X, not used or considered in model; minor, less than 0.001 percent; $\mathrm{Br}$, bromide; , approximately; --, not applicable, as no models found]

\begin{tabular}{|c|c|c|c|c|c|c|c|}
\hline \multirow[b]{2}{*}{$\begin{array}{l}\text { Sample } \\
\text { collection }\end{array}$} & \multirow[b]{2}{*}{$\begin{array}{c}\text { Hydrologic } \\
\text { condition } \\
\text { (dry period } \\
\text { or wet } \\
\text { period) }\end{array}$} & \multirow[b]{2}{*}{$\begin{array}{l}\text { Date for } \\
\text { listed } \\
\text { dis- } \\
\text { charge } \\
\text { condi- } \\
\text { tions }\end{array}$} & \multirow[b]{2}{*}{$\begin{array}{c}\text { San Marcos } \\
\text { Springs } \\
\text { discharge } \\
\left(\mathrm{ft}^{3} / \mathrm{s}\right) \\
\text { (mean } \\
\text { daily) }\end{array}$} & \multirow[b]{2}{*}{$\begin{array}{c}\text { Comal } \\
\text { Springs } \\
\text { discharge } \\
\left.\text { (ft } \mathrm{ft}^{3} / \mathrm{s}\right) \\
\text { (mean } \\
\text { daily) }\end{array}$} & \multirow[b]{2}{*}{$\begin{array}{c}\text { Blanco } \\
\text { River (Halifax } \\
\text { Ranch station) } \\
\text { discharge } \\
\left(\mathrm{ft}^{3} / \mathrm{s}\right) \\
\text { (mean } \\
\text { daily) }\end{array}$} & \multicolumn{2}{|c|}{ PHREEOC model details ${ }^{1-8}$} \\
\hline & & & & & & $\begin{array}{l}\text { Initial water } \\
\text { compositions }^{3-7}\end{array}$ & $\begin{array}{l}\text { Final water } \\
\text { composition }^{8}\end{array}$ \\
\hline
\end{tabular}

\section{Routine sampling}

Dec. 2008

dry

$12 / 1 / 08 \quad 102$

285

${ }^{10} 13$

Regional (Comal Springs, 12/2/08, and/

Deep Spring or well 4D, 12/16/08); saline zone $(12 / 1 / 08)$

Regional (Comal Springs, 12/2/08, and/ or well 4D, 12/16/08); saline zone; local (Blanco River 12/9/08)

Regional (Comal Springs, 12/2/08, and/ or well 4D, 12/16/08); Trinity aquifer

Regional flow (Comal Springs, 12/2/08, and/or well 4D, 12/16/08); Trinity aquifer; local (Blanco River 12/9/08)

Regional (Comal Springs, 12/2/08, and/ Diversion or well 4D, 12/16/08); saline zone Spring $(12 / 1 / 08)$

Regional (Comal Springs, 12/2/08, and/ or well 4D, 12/16/08); saline zone; local (Blanco River 12/9/08)

Regional (Comal Springs, 12/2/08, and/ or well 4D, 12/16/08); Trinity aquifer

Regional (Comal Springs, 12/2/08, and/ or well 4D, 12/16/08); Trinity aquifer; local (Blanco River 12/9/08)

\begin{tabular}{|c|c|c|c|c|c|c|c|}
\hline $\begin{array}{l}\text { May/June } \\
2009\end{array}$ & dry & $5 / 29 / 09$ & 93 & 220 & 8.1 & $\begin{array}{l}\text { Regional (Comal Springs, 5/27/09, and/ } \\
\text { or well 4D, 6/01/09); saline zone }\end{array}$ & $\begin{array}{c}\text { Deep Spring } \\
(5 / 27 / 09)\end{array}$ \\
\hline & & & & & & $\begin{array}{l}\text { Regional (Comal Springs, 5/27/09, and/ } \\
\text { or well 4D, 6/01/09); saline zone; } \\
\text { local (Blanco River 5/29/09) }\end{array}$ & \\
\hline
\end{tabular}

Regional (Comal Springs, 5/27/09, and/ or well 4D, 6/01/09); Trinity aquifer

Regional (Comal Springs, 5/27/09, and/ or well 4D, 6/01/09); Trinity aquifer; local (Blanco River 5/29/09)

$\begin{array}{cc}\text { Regional (Comal Springs, 5/27/09, and/ } & \text { Diversion } \\ \text { or well 4D, 6/01/09); saline zone } & \text { Spring } \\ & (5 / 27 / 09)\end{array}$

Regional (Comal Springs, 5/27/09, and/ or well 4D, 6/01/09); saline zone; local (Blanco River 5/29/09) 


\begin{tabular}{|c|c|c|c|c|c|c|c|c|c|}
\hline \multirow[b]{2}{*}{$\begin{array}{l}\text { Sample } \\
\text { collection }\end{array}$} & \multicolumn{9}{|c|}{ Model results, proportion of initial water compositions (percent) } \\
\hline & $\begin{array}{l}\text { Local } \\
\text { re- } \\
\text { charge } \\
\text { (Blanco } \\
\text { River) }^{3}\end{array}$ & $\begin{array}{l}\text { Regional- } \\
\text { flow } \\
\text { ground- } \\
\text { water } \\
\text { (Comal } \\
\text { Springs) }\end{array}$ & $\begin{array}{c}\text { Region- } \\
\text { al- } \\
\text { flow } \\
\text { ground- } \\
\text { water } \\
\text { (well } \\
\text { 4D) }{ }^{4}\end{array}$ & $\begin{array}{l}\text { Saline- } \\
\text { zone } \\
\text { ground- } \\
\text { water }^{5}\end{array}$ & $\begin{array}{c}\text { Trinity } \\
\text { aquifer } \\
\text { ground- } \\
\text { water } \\
\text { (regional/ } \\
\text { mineral- } \\
\text { ized) }^{6}\end{array}$ & $\begin{array}{c}\text { Trinity } \\
\text { aquifer } \\
\text { ground- } \\
\text { water } \\
\text { (local) }^{7}\end{array}$ & $\begin{array}{c}\text { Num- } \\
\text { ber of } \\
\text { models } \\
\text { found, } \\
\text { minimal } \\
\text { models } \\
\text { found }^{9}\end{array}$ & $\begin{array}{c}\text { Maximum } \\
\text { fractional } \\
\text { uncertain- } \\
\text { ty in model } \\
\text { (element } \\
\text { concen- } \\
\text { trations) }\end{array}$ & Comments \\
\hline \multicolumn{10}{|c|}{ Routine sampling } \\
\hline \multirow[t]{8}{*}{ Dec. 2008} & $\mathrm{X}$ & $\begin{array}{c}40.4- \\
53.2 \\
\end{array}$ & $\begin{array}{c}46.6- \\
59.4 \\
\end{array}$ & $0.1-0.2$ & $\mathrm{X}$ & $\mathrm{X}$ & 12,2 & 0.04 & \\
\hline & $\begin{array}{c}0-\text { mi- } \\
\text { nor }\end{array}$ & $\begin{array}{c}40.4- \\
53.2\end{array}$ & $\begin{array}{c}46.6- \\
59.4\end{array}$ & $0.1-0.2$ & $\mathrm{X}$ & $\mathrm{X}$ & 12,3 & 0.04 & $\begin{array}{l}\text { Little to no surface recharge occurring for these } \\
\text { hydrologic conditions, but local recharge } \\
\text { included for comparison. }\end{array}$ \\
\hline & $\mathrm{X}$ & $99.5-100$ & $0-0.5$ & $\mathrm{X}$ & 0 & $0-0.5$ & 61,1 & 0.10 & $\begin{array}{l}\text { Relatively high uncertainty needed; few models } \\
\text { include Trinity aquifer. }\end{array}$ \\
\hline & $0-0.6$ & $99.5-100$ & $0-0.5$ & $\mathrm{X}$ & 0-minor & $0-0.5$ & 34,1 & 0.10 & $\begin{array}{l}\text { Little to no surface recharge occurring for these } \\
\text { hydrologic conditions, but local recharge includ- } \\
\text { ed for comparison. Relatively high uncertainty } \\
\text { needed. Few models include Trinity aquifer. }\end{array}$ \\
\hline & $\mathrm{X}$ & $\begin{array}{c}39.6- \\
58.3\end{array}$ & $\begin{array}{l}41.7- \\
60.3\end{array}$ & $0-0.1$ & $\mathrm{X}$ & $\mathrm{X}$ & 30,9 & 0.06 & \\
\hline & $0-3.0$ & $\begin{array}{c}46.9- \\
58.9\end{array}$ & $\begin{array}{c}41.1- \\
51.5\end{array}$ & 0.1 & $X$ & $\mathrm{X}$ & 14,7 & 0.06 & $\begin{array}{l}\text { Little to no surface recharge occurring for these } \\
\text { hydrologic conditions, but local recharge } \\
\text { included for comparison. }\end{array}$ \\
\hline & $\mathrm{X}$ & $\begin{array}{c}58.3- \\
59.7\end{array}$ & $\begin{array}{c}40.3- \\
41.7\end{array}$ & $\mathrm{X}$ & 0 & $0-0.13$ & 16,2 & 0.06 & \\
\hline & $0-0.5$ & $\begin{array}{c}50.2- \\
59.7\end{array}$ & $\begin{array}{c}40.3- \\
49.8\end{array}$ & $\mathrm{X}$ & 0 & 0 & 9,1 & 0.06 & $\begin{array}{l}\text { Little to no surface recharge occurring for these } \\
\text { hydrologic conditions, but local recharge } \\
\text { included for comparison. No models include } \\
\text { Trinity aquifer. }\end{array}$ \\
\hline \multirow[t]{6}{*}{$\begin{array}{l}\text { May/June } \\
2009\end{array}$} & $\mathrm{X}$ & $\begin{array}{c}55.4- \\
67.0 \\
\end{array}$ & $\begin{array}{c}33.0- \\
44.5\end{array}$ & 0.1 & $X$ & $\mathrm{X}$ & 55,1 & 0.05 & \\
\hline & $\begin{array}{c}10.4- \\
20.3\end{array}$ & $\begin{array}{l}42.4- \\
48.6\end{array}$ & $\begin{array}{c}34.4- \\
42.2\end{array}$ & 0.1 & $\mathrm{X}$ & $\mathrm{X}$ & 23,1 & 0.04 & $\begin{array}{l}\text { Little to no surface recharge occurring for these } \\
\text { hydrologic conditions, but local recharge } \\
\text { included for comparison; estimated proportion } \\
\text { of local recharge unlikely based on hydrologic } \\
\text { conditions. }\end{array}$ \\
\hline & $\mathrm{X}$ & 96.9 & 3.1 & $\mathrm{X}$ & 0 & 0 & 33,1 & 0.06 & No models include Trinity aquifer. \\
\hline & $\begin{array}{c}18.4- \\
25.9\end{array}$ & $\begin{array}{c}71.0- \\
77.4\end{array}$ & $0-5.0$ & $\mathrm{X}$ & 0 & 0 & 13,1 & 0.05 & $\begin{array}{l}\text { Little to no surface recharge occurring for these } \\
\text { hydrologic conditions, but local recharge } \\
\text { included for comparison; estimated proportion } \\
\text { of local recharge unlikely based on hydrologic } \\
\text { conditions. No models include Trinity aquifer. }\end{array}$ \\
\hline & $\mathrm{X}$ & $\begin{array}{c}69.4- \\
69.9\end{array}$ & $\begin{array}{c}30.0- \\
30.6\end{array}$ & 0.1 & $\mathrm{X}$ & $\mathrm{X}$ & 57,1 & 0.06 & \\
\hline & $\begin{array}{c}4.5- \\
4.6\end{array}$ & 6.5 & 30.4 & 0.1 & $\mathrm{X}$ & $\mathrm{X}$ & 7,1 & 0.06 & $\begin{array}{l}\text { Little to no surface recharge occurring for these } \\
\text { hydrologic conditions, but local recharge } \\
\text { included for comparison. }\end{array}$ \\
\hline
\end{tabular}


Table 6. Summary of PHREEQC (Parkhurst and Appelo, 1999) inverse geochemical modeling results for San Marcos Springs, southcentral Texas (2008-10).-Continued

[See table 1 for complete U.S. Geological Survey station names and numbers. $\mathrm{ft}^{3} / \mathrm{s}$, cubic feet per second; X, not used or considered in model; minor, less than 0.001 percent; Br, bromide; , approximately; --, not applicable, as no models found]

\begin{tabular}{|c|c|c|c|c|c|c|c|}
\hline \multirow[b]{2}{*}{$\begin{array}{c}\text { Sample } \\
\text { collection }\end{array}$} & \multirow[b]{2}{*}{$\begin{array}{c}\text { Hydrologic } \\
\text { condition } \\
\text { (dry period } \\
\text { or wet } \\
\text { period) }\end{array}$} & \multirow[b]{2}{*}{$\begin{array}{l}\text { Date for } \\
\text { listed } \\
\text { dis- } \\
\text { charge } \\
\text { condi- } \\
\text { tions }\end{array}$} & \multirow[b]{2}{*}{$\begin{array}{c}\text { San Marcos } \\
\text { Springs } \\
\text { discharge } \\
\left.\text { (ft } \mathrm{ft}^{3} / \mathrm{s}\right) \\
\text { (mean } \\
\text { daily) }\end{array}$} & \multirow[b]{2}{*}{$\begin{array}{c}\text { Comal } \\
\text { Springs } \\
\text { discharge } \\
\left(\mathrm{ft}^{3} / \mathrm{s}\right) \\
\text { (mean } \\
\text { daily) }\end{array}$} & \multirow[b]{2}{*}{$\begin{array}{c}\text { Blanco } \\
\text { River (Halifax } \\
\text { Ranch station) } \\
\text { discharge } \\
\left(\mathrm{ft}^{3} / \mathbf{s}\right) \\
\text { (mean } \\
\text { daily) }\end{array}$} & \multicolumn{2}{|c|}{ PHREEOC model details ${ }^{1-8}$} \\
\hline & & & & & & $\begin{array}{c}\text { Initial water } \\
\text { compositions }^{3-7}\end{array}$ & $\begin{array}{l}\text { Final water } \\
\text { composition }^{8}\end{array}$ \\
\hline
\end{tabular}

Routine sampling-Continued

Regional (Comal Springs, 5/27/09, and/ or well 4D, 6/01/09); Trinity aquifer

Regional (Comal Springs, 5/27/09, and/ or well 4D, 6/01/09); Trinity aquifer; local (Blanco River 5/29/09)

\begin{tabular}{|c|c|c|c|c|c|c|c|}
\hline July 2009 & dry & $7 / 21 / 09$ & 86 & 170 & 3 & $\begin{array}{l}\text { Regional (Comal Springs, } 7 / 16 / 09 \text {, and/ } \\
\text { or well 4D, 7/20/09); saline zone }\end{array}$ & $\begin{array}{c}\text { Deep Spring } \\
(7 / 21 / 09)\end{array}$ \\
\hline & & & & & & $\begin{array}{l}\text { Regional (Comal Springs, } 7 / 16 / 09 \text {, and/ } \\
\text { or well 4D, } 7 / 20 / 09 \text { ); saline zone; lo- } \\
\text { cal (Blanco River } 7 / 17 / 09)\end{array}$ & \\
\hline
\end{tabular}

Regional (Comal Springs, 7/16/09, and/ or well 4D, 7/20/09); Trinity aquifer

Regional (Comal Springs, 7/16/09, and/ or well 4D, 7/20/09); Trinity aquifer; local (Blanco River 7/17/09)

Regional (Comal Springs, 7/16/09, and/ Diversion or well 4D, 7/20/09); saline zone Spring $(7 / 21 / 09)$

Regional (Comal Springs, 7/16/09, and/ or well 4D, 7/20/09); saline zone; local (Blanco River 7/17/09)

Regional (Comal Springs, 7/16/09, and/ or well 4D, 7/20/09); Trinity aquifer

Regional (Comal Springs, 7/16/09, and/ or well 4D, 7/20/09); Trinity aquifer; local (Blanco River 7/17/09)

\begin{tabular}{|c|c|c|c|c|c|c|c|}
\hline $\begin{array}{l}\text { Aug./Sept. } \\
2009\end{array}$ & dry & $9 / 1 / 09$ & 85 & 163 & 2.4 & $\begin{array}{l}\text { Regional (Comal Springs, } 8 / 31 / 09 \text {, and/ } \\
\text { or well 4D, } 8 / 31 / 09 \text { ); saline zone }\end{array}$ & $\begin{array}{l}\text { Deep Spring } \\
(9 / 1 / 09)\end{array}$ \\
\hline
\end{tabular}

Regional (Comal Springs, 8/31/09, and/ or well 4D, 8/31/09); saline zone; local (Blanco River 9/2/09) 


\begin{tabular}{|c|c|c|c|c|c|c|c|c|c|}
\hline \multirow[b]{2}{*}{$\begin{array}{l}\text { Sample } \\
\text { collection }\end{array}$} & \multicolumn{9}{|c|}{ Model results, proportion of initial water compositions (percent) ${ }^{1-8}$} \\
\hline & $\begin{array}{l}\text { Local } \\
\text { re- } \\
\text { charge } \\
\text { (Blanco } \\
\text { River }^{3}\end{array}$ & $\begin{array}{l}\text { Regional- } \\
\text { flow } \\
\text { ground- } \\
\text { water } \\
\text { (Comal } \\
\text { Springs) }\end{array}$ & $\begin{array}{c}\text { Region- } \\
\text { al- } \\
\text { flow } \\
\text { ground- } \\
\text { water } \\
\text { (well } \\
\text { 4D) }\end{array}$ & $\begin{array}{l}\text { Saline- } \\
\text { zone } \\
\text { ground- } \\
\text { water }^{5}\end{array}$ & $\begin{array}{c}\text { Trinity } \\
\text { aquifer } \\
\text { ground- } \\
\text { water } \\
\text { (regional/ } \\
\text { mineral- } \\
\text { ized) }^{6} \\
\end{array}$ & $\begin{array}{l}\text { Trinity } \\
\text { aquifer } \\
\text { ground- } \\
\text { water } \\
\text { (local) }^{7}\end{array}$ & $\begin{array}{c}\text { Num- } \\
\text { ber of } \\
\text { models } \\
\text { found, } \\
\text { minimal } \\
\text { models } \\
\text { found }^{9} \\
\end{array}$ & $\begin{array}{c}\text { Maximum } \\
\text { fractional } \\
\text { uncertain- } \\
\text { ty in model } \\
\text { (element } \\
\text { concen- } \\
\text { trations) }\end{array}$ & Comments \\
\hline \multicolumn{10}{|c|}{ Routine sampling-Continued } \\
\hline & $\mathrm{X}$ & $90.0-100$ & $0-10$ & $\mathrm{X}$ & 0 & 0 & 17,1 & 0.08 & $\begin{array}{l}\text { Relatively high uncertainty needed. No models } \\
\text { include Trinity aquifer. }\end{array}$ \\
\hline & $\begin{array}{c}0.3- \\
1.2\end{array}$ & $\begin{array}{c}91.3- \\
92.0\end{array}$ & $7.4-7.8$ & $\mathrm{X}$ & 0 & $\begin{array}{l}0-\text { mi- } \\
\text { nor }\end{array}$ & 15,1 & 0.07 & $\begin{array}{l}\text { Little to no surface recharge occurring for these } \\
\text { hydrologic conditions, but local recharge } \\
\text { included in model for comparison. Relatively } \\
\text { high uncertainty needed. }\end{array}$ \\
\hline \multirow[t]{8}{*}{ July 2009} & $\mathrm{X}$ & $\begin{array}{c}41.9- \\
51.9\end{array}$ & $\begin{array}{c}47.9- \\
57.9\end{array}$ & 0.2 & $\mathrm{X}$ & $\mathrm{X}$ & 9,1 & 0.04 & \\
\hline & $\begin{array}{c}6.0- \\
9.2\end{array}$ & $\begin{array}{c}11.8- \\
32.6\end{array}$ & $\begin{array}{c}61.2- \\
78.8\end{array}$ & 0.2 & $\mathrm{X}$ & $\mathrm{X}$ & 8,1 & 0.03 & $\begin{array}{l}\text { Little to no surface recharge occurring for } \\
\text { these hydrologic conditions, but local } \\
\text { recharge included for comparison; estimated } \\
\text { proportion of local recharge unlikely based on } \\
\text { hydrologic conditions. }\end{array}$ \\
\hline & $\mathrm{X}$ & -- & -- & $\mathrm{X}$ & -- & -- & -- & 0.10 & No models. \\
\hline & $\mathrm{X}$ & -- & -- & $\mathrm{X}$ & -- & -- & -- & 0.10 & No models. \\
\hline & $\mathrm{X}$ & $\begin{array}{c}11.2- \\
14.6\end{array}$ & $\begin{array}{c}85.3- \\
88.7\end{array}$ & 0.1 & $\mathrm{X}$ & $\mathrm{X}$ & 7,1 & 0.05 & \\
\hline & $\begin{array}{c}2.6- \\
6.8\end{array}$ & $0-10.5$ & $\begin{array}{c}86.8- \\
96.4\end{array}$ & 0.1 & $\mathrm{X}$ & $\mathrm{X}$ & 18,3 & 0.04 & $\begin{array}{l}\text { Little to no surface recharge occurring for } \\
\text { these hydrologic conditions, but local } \\
\text { recharge included for comparison. }\end{array}$ \\
\hline & $\mathrm{X}$ & $\begin{array}{c}78.3- \\
87.2\end{array}$ & $\begin{array}{c}12.8- \\
21.7\end{array}$ & $\mathrm{X}$ & -- & $0.1-0.6$ & 21,1 & 0.09 & Relatively high uncertainty needed. \\
\hline & $\begin{array}{c}13.7- \\
15.6\end{array}$ & $\begin{array}{l}36.1- \\
42.2\end{array}$ & $\begin{array}{c}44.1- \\
48.4\end{array}$ & $\mathrm{X}$ & -- & $0-0.2$ & 10,1 & 0.07 & $\begin{array}{l}\text { Little to no surface recharge occurring for these } \\
\text { hydrologic conditions, but local recharge } \\
\text { included for comparison; relatively high } \\
\text { proportion of local recharge estimated is } \\
\text { unlikely based on hydrologic conditions. } \\
\text { Relatively high uncertainty needed. }\end{array}$ \\
\hline \multirow[t]{3}{*}{$\begin{array}{l}\text { Aug./Sept. } \\
2009\end{array}$} & $\mathrm{X}$ & 99.8 & 0 -minor & 0.2 & $\mathrm{X}$ & $\mathrm{X}$ & 9,1 & 0.08 & Relatively high uncertainty needed. \\
\hline & $\mathrm{X}$ & $\begin{array}{c}70.2- \\
70.5\end{array}$ & $\begin{array}{c}29.4- \\
29.7\end{array}$ & 0.1 & $\mathrm{X}$ & $\mathrm{X}$ & 8,1 & 0.04 & $\begin{array}{l}\text { No Br in model balances (composition of Deep } \\
\text { Spring on 9/1/09 has anomalously high } \mathrm{Br} \text { ). }\end{array}$ \\
\hline & $0-3.3$ & $\begin{array}{c}66.0- \\
70.5\end{array}$ & $\begin{array}{c}29.3- \\
30.9\end{array}$ & 0.1 & $\mathrm{X}$ & $\mathrm{X}$ & 14,1 & 0.04 & $\begin{array}{l}\text { Little to no surface recharge occurring for these } \\
\text { hydrologic conditions, but local recharge } \\
\text { included for comparison. No Br in model } \\
\text { balances (composition of Deep Spring on } \\
\text { 9/1/09 has anomalously high Br). }\end{array}$ \\
\hline
\end{tabular}


Table 6. Summary of PHREEOC (Parkhurst and Appelo, 1999) inverse geochemical modeling results for San Marcos Springs, southcentral Texas (2008-10).-Continued

[See table 1 for complete U.S. Geological Survey station names and numbers. $\mathrm{ft}^{3} / \mathrm{s}$, cubic feet per second; X, not used or considered in model; minor, less than 0.001 percent; Br, bromide; , approximately; --, not applicable, as no models found]

\begin{tabular}{|c|c|c|c|c|c|c|c|}
\hline \multirow[b]{2}{*}{$\begin{array}{l}\text { Sample } \\
\text { collection }\end{array}$} & \multirow[b]{2}{*}{$\begin{array}{c}\text { Hydrologic } \\
\text { condition } \\
\text { (dry period } \\
\text { or wet } \\
\text { period) }\end{array}$} & \multirow[b]{2}{*}{$\begin{array}{l}\text { Date for } \\
\text { listed } \\
\text { dis- } \\
\text { charge } \\
\text { condi- } \\
\text { tions }\end{array}$} & \multirow[b]{2}{*}{$\begin{array}{c}\text { San Marcos } \\
\text { Springs } \\
\text { discharge } \\
\left(\mathrm{ft}^{3} / \mathrm{s}\right) \\
\text { (mean } \\
\text { daily) }\end{array}$} & \multirow[b]{2}{*}{$\begin{array}{c}\text { Comal } \\
\text { Springs } \\
\text { discharge } \\
\left(\mathrm{ft}^{3} / \mathrm{s}\right) \\
\text { (mean } \\
\text { daily) }\end{array}$} & \multirow[b]{2}{*}{$\begin{array}{c}\text { Blanco } \\
\text { River (Halifax } \\
\text { Ranch station) } \\
\text { discharge } \\
\left.\text { (ft }{ }^{3} / \mathbf{s}\right) \\
\text { (mean } \\
\text { daily) }\end{array}$} & \multicolumn{2}{|c|}{ PHREEQC model details $^{1-8}$} \\
\hline & & & & & & $\begin{array}{c}\text { Initial water } \\
\text { compositions }^{3-7}\end{array}$ & $\begin{array}{l}\text { Final water } \\
\text { composition }^{8}\end{array}$ \\
\hline
\end{tabular}

Routine sampling-Continued

Regional (Comal Springs, 8/31/09, and/ or well 4D, 8/31/09); Trinity aquifer

Regional (Comal Springs, 8/31/09, and/ or well 4D, 8/31/09); Trinity aquifer; local (Blanco River 9/2/09)

Regional (Comal Springs, 8/31/09, and/ Diversion or well 4D, 8/31/09); saline zone Spring

Regional (Comal Springs, 8/31/09, and/ $(9 / 1 / 09)$ or well 4D, 8/31/09); saline zone; local (Blanco River 9/2/09)

Regional (Comal Springs, 8/31/09, and/ or well 4D, 8/31/09); Trinity aquifer

Regional (Comal Springs, 8/31/09, and/ or well 4D, 8/31/09); Trinity aquifer; local (Blanco River 9/2/09)

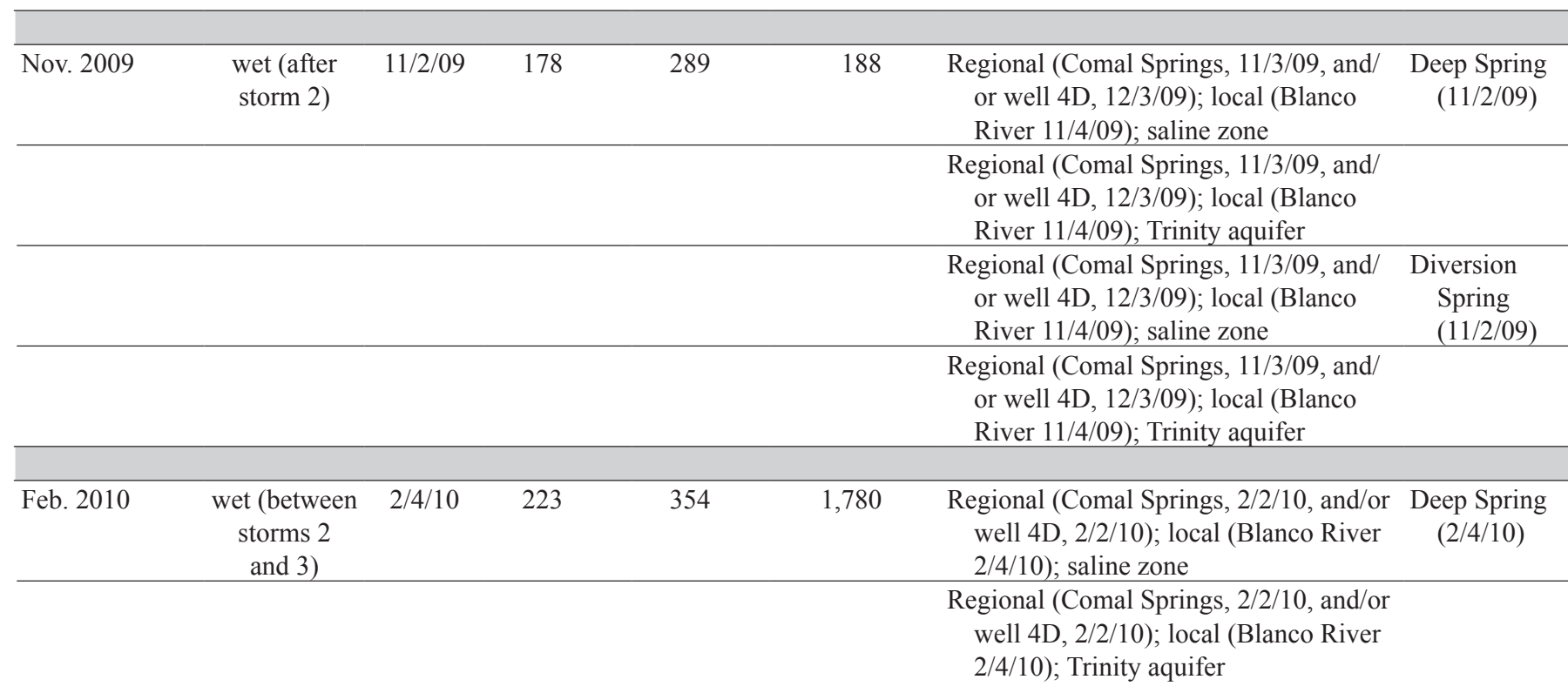
Regional (Comal Springs, 2/2/10, and/or Diversion well 4D, 2/2/10); local (Blanco River Spring 2/4/10); saline zone $(2 / 4 / 10)$

Regional (Comal Springs, 2/2/10, and/or well 4D, 2/2/10); local (Blanco River 2/4/10); Trinity aquifer 


\begin{tabular}{|c|c|c|c|c|c|c|c|c|c|}
\hline \multirow[b]{2}{*}{$\begin{array}{l}\text { Sample } \\
\text { collection }\end{array}$} & \multicolumn{9}{|c|}{ Model results, proportion of initial water compositions (percent) ${ }^{1-8}$} \\
\hline & $\begin{array}{l}\text { Local } \\
\text { re- } \\
\text { charge } \\
\text { (Blanco } \\
\text { River) }\end{array}$ & $\begin{array}{l}\text { Regional- } \\
\text { flow } \\
\text { ground- } \\
\text { water } \\
\text { (Comal } \\
\text { Springs) }\end{array}$ & $\begin{array}{c}\text { Region- } \\
\text { al- } \\
\text { flow } \\
\text { ground- } \\
\text { water } \\
\text { (well } \\
\text { 4D) } \\
\end{array}$ & $\begin{array}{l}\text { Saline- } \\
\text { zone } \\
\text { ground- } \\
\text { water }^{5}\end{array}$ & $\begin{array}{c}\text { Trinity } \\
\text { aquifer } \\
\text { ground- } \\
\text { water } \\
\text { (regional/ } \\
\text { mineral- } \\
\text { ized) }^{6}\end{array}$ & $\begin{array}{c}\text { Trinity } \\
\text { aquifer } \\
\text { ground- } \\
\text { water } \\
\text { (local) }^{7}\end{array}$ & $\begin{array}{c}\text { Num- } \\
\text { ber of } \\
\text { models } \\
\text { found, } \\
\text { minimal } \\
\text { models } \\
\text { found }^{9}\end{array}$ & $\begin{array}{c}\text { Maximum } \\
\text { fractional } \\
\text { uncertain- } \\
\text { ty in model } \\
\text { (element } \\
\text { concen- } \\
\text { trations) }\end{array}$ & Comments \\
\hline \multicolumn{10}{|c|}{ Routine sampling-Continued } \\
\hline & $\mathrm{X}$ & -- & -- & $\mathrm{X}$ & -- & -- & 0 & 0.10 & No models (with or without $\mathrm{Br}$ in constraints). \\
\hline & -- & -- & -- & $\mathrm{X}$ & -- & -- & 0 & 0.10 & No models (with or without $\mathrm{Br}$ in constraints). \\
\hline & $\mathrm{X}$ & $\begin{array}{c}60.4- \\
71.1\end{array}$ & $\begin{array}{c}28.8- \\
39.5\end{array}$ & 0.1 & $\mathrm{X}$ & $\mathrm{X}$ & 25,1 & 0.08 & Relatively high uncertainty needed. \\
\hline & $\begin{array}{c}0-\text { mi- } \\
\text { nor }\end{array}$ & $\begin{array}{c}56.9- \\
57.7\end{array}$ & $\begin{array}{c}42.2- \\
43.0\end{array}$ & 0.1 & $\mathrm{X}$ & $\mathrm{X}$ & 12,1 & 0.07 & $\begin{array}{l}\text { Little to no surface recharge occurring for these } \\
\text { hydrologic conditions, but local recharge } \\
\text { included for comparison. Relatively high } \\
\text { uncertainty needed. }\end{array}$ \\
\hline & $\mathrm{X}$ & $\begin{array}{c}84.9- \\
86.8\end{array}$ & $\begin{array}{c}13.2- \\
15.1 \\
\end{array}$ & $\mathrm{X}$ & 0 & 0 & 25,1 & 0.08 & $\begin{array}{l}\text { Relatively high uncertainty needed; no models } \\
\text { include Trinity aquifer. }\end{array}$ \\
\hline & $\begin{array}{c}0-\mathrm{mi}- \\
\text { nor }\end{array}$ & $\begin{array}{c}84.9- \\
99.7\end{array}$ & $0.3-15.1$ & $X$ & 0 -minor & $0-0.3$ & 17,1 & 0.09 & $\begin{array}{l}\text { Little to no surface recharge occurring for these } \\
\text { hydrologic conditions, but local recharge } \\
\text { included for comparison. Relatively high } \\
\text { uncertainty needed. }\end{array}$ \\
\hline \multirow[t]{4}{*}{ Nov. 2009} & $0-11.9$ & $\begin{array}{c}78.7- \\
88.9\end{array}$ & $0-13.2$ & 0.1 & $\mathrm{X}$ & $\mathrm{X}$ & 12,6 & 0.04 & $\begin{array}{l}\text { In time period of large and rapid increase in San } \\
\text { Marcos Springs discharge; rising hydrograph. }\end{array}$ \\
\hline & $0-6.5$ & $93.5-100$ & 0 -minor & $X$ & 0.0 & $0-0.7$ & 11,3 & 0.09 & $\begin{array}{l}\text { In time period of large and rapid increase in San } \\
\text { Marcos Springs discharge; rising hydrograph; } \\
\text { relatively high uncertainty needed. }\end{array}$ \\
\hline & $\begin{array}{c}8.2- \\
9.6\end{array}$ & $\begin{array}{c}90.4- \\
91.8\end{array}$ & 0-minor & $\begin{array}{c}0.05- \\
0.06\end{array}$ & $X$ & $X$ & 8,1 & 0.04 & $\begin{array}{l}\text { In time period of large and rapid increase in San } \\
\text { Marcos Springs discharge; rising hydrograph. }\end{array}$ \\
\hline & $\begin{array}{l}3.6- \\
23.5\end{array}$ & $\begin{array}{l}75.3- \\
95.7\end{array}$ & 0 -minor & $X$ & $0.7-1.2$ & $0-0.8$ & 7,1 & 0.05 & $\begin{array}{l}\text { In time period of large and rapid increase in San } \\
\text { Marcos Springs discharge; rising hydrograph. }\end{array}$ \\
\hline \multirow[t]{4}{*}{ Feb. 2010} & 15.9 & 40.7 & 43.2 & 0.2 & $X$ & $\mathrm{X}$ & 4,1 & 0.03 & $\begin{array}{l}\text { In time period of large and rapid increase in San } \\
\text { Marcos Springs discharge; approaching highest } \\
\text { discharge during study; rising hydrograph. }\end{array}$ \\
\hline & $0-0.1$ & $99.9-100$ & 0 -minor & $X$ & 0.0 & $\begin{array}{c}0-\text { mi- } \\
\text { nor }\end{array}$ & 24,1 & 0.08 & $\begin{array}{l}\text { In time period of large and rapid increase in San } \\
\text { Marcos Springs discharge; approaching highest } \\
\text { discharge during study; rising hydrograph; } \\
\text { relatively high uncertainty needed; Trinity } \\
\text { aquifer included in only one model. }\end{array}$ \\
\hline & $\begin{array}{l}6.6- \\
10.3\end{array}$ & $\begin{array}{c}72.9- \\
73.9\end{array}$ & $\begin{array}{c}15.7- \\
20.4\end{array}$ & 0.1 & $\mathrm{X}$ & $\mathrm{X}$ & 5,1 & 0.03 & $\begin{array}{l}\text { In time period of large and rapid increase in San } \\
\text { Marcos Springs discharge; approaching highest } \\
\text { discharge during study; rising hydrograph. }\end{array}$ \\
\hline & -- & -- & -- & $\mathrm{X}$ & -- & -- & 0 & 0.10 & $\begin{array}{l}\text { In time period of large and rapid increase in San } \\
\text { Marcos Springs discharge; approaching highest } \\
\text { discharge during study; rising hydrograph; no } \\
\text { models. }\end{array}$ \\
\hline
\end{tabular}


Table 6. Summary of PHREEOC (Parkhurst and Appelo, 1999) inverse geochemical modeling results for San Marcos Springs, southcentral Texas (2008-10).-Continued

[See table 1 for complete U.S. Geological Survey station names and numbers. $\mathrm{ft}^{3} / \mathrm{s}$, cubic feet per second; X, not used or considered in model; minor, less than 0.001 percent; $\mathrm{Br}$, bromide;, approximately; --, not applicable, as no models found]

\begin{tabular}{|c|c|c|c|c|c|c|c|}
\hline \multirow[b]{2}{*}{$\begin{array}{l}\text { Sample } \\
\text { collection }\end{array}$} & \multirow[b]{2}{*}{$\begin{array}{l}\text { Hydrologic } \\
\text { condition } \\
\text { (dry period } \\
\text { or wet } \\
\text { period) }\end{array}$} & \multirow[b]{2}{*}{$\begin{array}{l}\text { Date for } \\
\text { listed } \\
\text { dis- } \\
\text { charge } \\
\text { condi- } \\
\text { tions }\end{array}$} & \multirow[b]{2}{*}{$\begin{array}{c}\text { San Marcos } \\
\text { Springs } \\
\text { discharge } \\
\left(\mathrm{ft}^{3} / \mathrm{s}\right) \\
\text { (mean } \\
\text { daily) }\end{array}$} & \multirow[b]{2}{*}{$\begin{array}{c}\text { Comal } \\
\text { Springs } \\
\text { discharge } \\
\left.\text { (ft }{ }^{3} / \mathrm{s}\right) \\
\text { (mean } \\
\text { daily) }\end{array}$} & \multirow[b]{2}{*}{$\begin{array}{c}\text { Blanco } \\
\text { River (Halifax } \\
\text { Ranch station) } \\
\text { discharge } \\
\left(\mathbf{f t}^{3} / \mathrm{s}\right) \\
\text { (mean } \\
\text { daily) }\end{array}$} & \multicolumn{2}{|l|}{ PHREEQC model details $^{1-8}$} \\
\hline & & & & & & $\begin{array}{l}\text { Initial water } \\
\text { compositions }^{3-7}\end{array}$ & $\begin{array}{l}\text { Final water } \\
\text { composition }^{8}\end{array}$ \\
\hline \multicolumn{8}{|c|}{ Routine sampling-Continued } \\
\hline \multirow[t]{5}{*}{ June 2010} & wet & $6 / 7 / 10$ & 220 & 355 & 139 & $\begin{array}{l}\text { Regional (Comal Springs, 6/1/10, and/or } \\
\text { well 4D, 6/3/10); local (Blanco River } \\
\text { 6/2/10); saline zone }\end{array}$ & $\begin{array}{c}\text { Deep Spring } \\
(6 / 7 / 10)\end{array}$ \\
\hline & & & & & & $\begin{array}{l}\text { Regional (Comal Springs, 6/1/10, and/or } \\
\text { well 4D, 6/3/10); local (Blanco River } \\
\text { 6/2/10); Trinity aquifer }\end{array}$ & \\
\hline & & & & & & $\begin{array}{l}\text { Regional (Comal Springs, 6/1/10, and/or } \\
\text { well 4D, 6/3/10); local (Blanco River } \\
\text { 6/2/10); Trinity aquifer }\end{array}$ & \\
\hline & & & & & & $\begin{array}{l}\text { Regional (Comal Springs, } 6 / 1 / 10 \text {, and } / \\
\text { or well 4D, 6/3/10); Blanco River } \\
(6 / 2 / 10) \text {; saline zone }\end{array}$ & $\begin{array}{l}\text { Weissmuller } \\
\text { Spring } \\
(6 / 7 / 10)\end{array}$ \\
\hline & & & & & & $\begin{array}{l}\text { Regional (Comal Springs, 6/1/10, and/or } \\
\text { well 4D, 6/3/10); local (Blanco River } \\
\text { 6/2/10); Trinity aquifer }\end{array}$ & \\
\hline \multirow[t]{4}{*}{$\begin{array}{l}\text { Nov./Dec. } \\
2010\end{array}$} & wet & $12 / 1 / 10$ & 171 & 332 & 55 & $\begin{array}{l}\text { Regional (Comal Springs, 11/30/10, and/ } \\
\text { or well 4D, 11/30/10); local (Blanco } \\
\text { River 12/1/10); saline zone }\end{array}$ & $\begin{array}{c}\text { Deep Spring } \\
(12 / 1 / 10)\end{array}$ \\
\hline & & & & & & $\begin{array}{l}\text { Regional (Comal Springs, 11/30/10, and/ } \\
\text { or well 4D, 11/30/10); local (Blanco } \\
\text { River 12/1/10); Trinity aquifer }\end{array}$ & \\
\hline & & & & & & $\begin{array}{l}\text { Regional (Comal Springs, 11/30/10, and/ } \\
\text { or well 4D, 11/30/10); local (Blanco } \\
\text { River 12/1/10); saline zone }\end{array}$ & $\begin{array}{l}\text { Weissmuller } \\
\text { Spring } \\
(12 / 1 / 10)\end{array}$ \\
\hline & & & & & & $\begin{array}{l}\text { Regional (Comal Springs, 11/30/10, and/ } \\
\text { or well 4D, 11/30/10); local (Blanco } \\
\text { River 12/1/10); Trinity aquifer }\end{array}$ & \\
\hline
\end{tabular}




\begin{tabular}{|c|c|c|c|c|c|c|c|c|c|}
\hline \multirow[b]{2}{*}{$\begin{array}{c}\text { Sample } \\
\text { collection }\end{array}$} & \multicolumn{9}{|c|}{ Model results, proportion of initial water compositions (percent) ${ }^{1-8}$} \\
\hline & $\begin{array}{c}\text { Local } \\
\text { re- } \\
\text { charge } \\
\text { (Blanco }^{\text {River) }}{ }^{3}\end{array}$ & $\begin{array}{l}\text { Regional- } \\
\text { flow } \\
\text { ground- } \\
\text { water } \\
\text { (Comal } \\
\text { Springs) }\end{array}$ & $\begin{array}{c}\text { Region- } \\
\text { al- } \\
\text { flow } \\
\text { ground- } \\
\text { water } \\
\text { (well } \\
\text { 4D) }\end{array}$ & $\begin{array}{l}\text { Saline- } \\
\text { zone } \\
\text { ground- } \\
\text { water }^{5}\end{array}$ & $\begin{array}{c}\text { Trinity } \\
\text { aquifer } \\
\text { ground- } \\
\text { water } \\
\text { (regional/ } \\
\text { mineral- } \\
\text { ized) }^{6} \\
\end{array}$ & $\begin{array}{c}\text { Trinity } \\
\text { aquifer } \\
\text { ground- } \\
\text { water } \\
\text { (local) }^{7} \\
\end{array}$ & $\begin{array}{c}\text { Num- } \\
\text { ber of } \\
\text { models } \\
\text { found, } \\
\text { minimal } \\
\text { models } \\
\text { found }^{9} \\
\end{array}$ & $\begin{array}{c}\text { Maximum } \\
\text { fractional } \\
\text { uncertain- } \\
\text { ty in model } \\
\text { (element } \\
\text { concen- } \\
\text { trations) }\end{array}$ & Comments \\
\hline \multicolumn{10}{|c|}{ Routine sampling-Continued } \\
\hline \multirow[t]{6}{*}{ June 2010} & $\begin{array}{l}2.5- \\
17.5\end{array}$ & $\begin{array}{c}43.9- \\
76.5\end{array}$ & $\begin{array}{c}21.0- \\
38.9\end{array}$ & 0.1 & $\mathrm{X}$ & $\mathrm{X}$ & 12,4 & 0.04 & $\begin{array}{l}\text { Time period associated with falling hydrograph; } \\
\text { near date (following) of highest discharge } \\
\text { during study. }\end{array}$ \\
\hline & -- & -- & -- & $\mathrm{X}$ & -- & -- & 0 & 0.10 & $\begin{array}{l}\text { Time period associated with falling hydrograph; } \\
\text { near date (following) of highest discharge } \\
\text { during study; no models. }\end{array}$ \\
\hline & $\begin{array}{l}8.1- \\
17.7\end{array}$ & $\begin{array}{c}40.1- \\
57.7\end{array}$ & $\begin{array}{c}33.3- \\
42.7\end{array}$ & 0.1 & $\mathrm{X}$ & $\mathrm{X}$ & 14,4 & 0.03 & $\begin{array}{l}\text { Time period associated with falling hydrograph; } \\
\text { near date (following) of highest discharge } \\
\text { during study. }\end{array}$ \\
\hline & $0-0.1$ & $97.8-100$ & $0-0.2$ & $\mathrm{X}$ & $0-0.8$ & $0-1.3$ & 14,2 & 0.09 & $\begin{array}{l}\text { Time period associated with falling hydrograph; } \\
\text { near date (following) of highest discharge } \\
\text { during study; relatively high uncertainty needed. }\end{array}$ \\
\hline & $\begin{array}{l}4.9- \\
12.6\end{array}$ & $\begin{array}{c}17.3- \\
59.0\end{array}$ & $\begin{array}{c}34.6- \\
69.8\end{array}$ & 0.2 & $\mathrm{X}$ & $\mathrm{X}$ & 5,1 & 0.03 & $\begin{array}{l}\text { Time period associated with falling } \\
\text { hydrograph; near date (following) of } \\
\text { highest discharge during study. }\end{array}$ \\
\hline & -- & -- & -- & $\mathrm{X}$ & -- & -- & 0 & 0.10 & $\begin{array}{l}\text { Time period associated with falling hydrograph; } \\
\text { near date (following) of highest discharge } \\
\text { during study; no models. }\end{array}$ \\
\hline \multirow[t]{6}{*}{$\begin{array}{c}\text { Nov./Dec. } \\
2010\end{array}$} & $0-5.7$ & $\begin{array}{c}16.7- \\
21.4\end{array}$ & $\begin{array}{c}75.8- \\
83.1\end{array}$ & 0.2 & $\mathrm{X}$ & $\mathrm{X}$ & 12,3 & 0.04 & $\begin{array}{l}\text { Time period associated with falling hydrograph; } \\
\sim 3 \text { months post large recharge event from } \\
\text { tropical storm Hermine. }\end{array}$ \\
\hline & $0-3.5$ & $95.9-100$ & $0-2.4$ & $\mathrm{X}$ & 0 & $\begin{array}{c}\text { 0-mi- } \\
\text { nor }\end{array}$ & 9,1 & 0.10 & $\begin{array}{l}\text { Time period associated with falling hydrograph; } \\
\sim 3 \text { months post large recharge event from tropi- } \\
\text { cal storm Hermine; relatively high uncertainty } \\
\text { needed. }\end{array}$ \\
\hline & $\begin{array}{c}21.0- \\
24.4\end{array}$ & $\begin{array}{c}74.4- \\
79.0\end{array}$ & $0-1.1$ & 0.1 & $\mathrm{X}$ & $\mathrm{X}$ & 22,1 & 0.06 & $\begin{array}{l}\text { Time period associated with falling hydrograph; } \\
\sim 3 \text { months post large recharge event from } \\
\text { tropical storm Hermine. }\end{array}$ \\
\hline & $0-9.1$ & $90.9-100$ & $0-6.1$ & $X$ & 0 & $0-0.9$ & 14,1 & 0.10 & $\begin{array}{l}\text { Time period associated with falling hydrograph; } \\
\sim 3 \text { months post large recharge event from } \\
\text { tropical storm Hermine; relatively high } \\
\text { uncertainty needed. }\end{array}$ \\
\hline & $\begin{array}{c}25.3- \\
28.9\end{array}$ & $\begin{array}{c}68.1- \\
74.7\end{array}$ & $0-3.0$ & 0.1 & $X$ & $X$ & 12,1 & 0.06 & $\begin{array}{l}\text { Time period associated with falling hydrograph; } \\
\sim 3 \text { months post large recharge event from } \\
\text { tropical storm Hermine. }\end{array}$ \\
\hline & -- & -- & -- & $\mathrm{X}$ & -- & -- & 0 & 0.10 & $\begin{array}{l}\text { Time period associated with falling hydrograph; } \\
\sim 3 \text { months post large recharge event from } \\
\text { tropical storm Hermine; no models. }\end{array}$ \\
\hline
\end{tabular}


Table 6. Summary of PHREEOC (Parkhurst and Appelo, 1999) inverse geochemical modeling results for San Marcos Springs, southcentral Texas (2008-10).-Continued

[See table 1 for complete U.S. Geological Survey station names and numbers. $\mathrm{ft}^{3} / \mathrm{s}$, cubic feet per second; X, not used or considered in model; minor, less than 0.001 percent; Br, bromide; , approximately; --, not applicable, as no models found]

\begin{tabular}{|c|c|c|c|c|c|c|c|}
\hline \multirow[b]{2}{*}{$\begin{array}{l}\text { Sample } \\
\text { collection }\end{array}$} & \multirow[b]{2}{*}{$\begin{array}{c}\text { Hydrologic } \\
\text { condition } \\
\text { (dry period } \\
\text { or wet } \\
\text { period) }\end{array}$} & \multirow[b]{2}{*}{$\begin{array}{l}\text { Date for } \\
\text { listed } \\
\text { dis- } \\
\text { charge } \\
\text { condi- } \\
\text { tions }\end{array}$} & \multirow[b]{2}{*}{$\begin{array}{c}\text { San Marcos } \\
\text { Springs } \\
\text { discharge } \\
\left(\mathrm{ft}^{3} / \mathrm{s}\right) \\
\text { (mean } \\
\text { daily) }\end{array}$} & \multirow[b]{2}{*}{$\begin{array}{c}\text { Comal } \\
\text { Springs } \\
\text { discharge } \\
\left(\mathrm{ft}^{3} / \mathrm{s}\right) \\
\text { (mean } \\
\text { daily) }\end{array}$} & \multirow[b]{2}{*}{$\begin{array}{c}\text { Blanco } \\
\text { River (Halifax } \\
\text { Ranch station) } \\
\text { discharge } \\
\left(\mathrm{ft}^{3} / \mathrm{s}\right) \\
\text { (mean } \\
\text { daily) }\end{array}$} & \multicolumn{2}{|c|}{ PHREEOC model details ${ }^{1-8}$} \\
\hline & & & & & & $\begin{array}{c}\text { Initial water } \\
\text { compositions }^{3-7}\end{array}$ & $\begin{array}{l}\text { Final water } \\
\text { composition }^{8}\end{array}$ \\
\hline
\end{tabular}

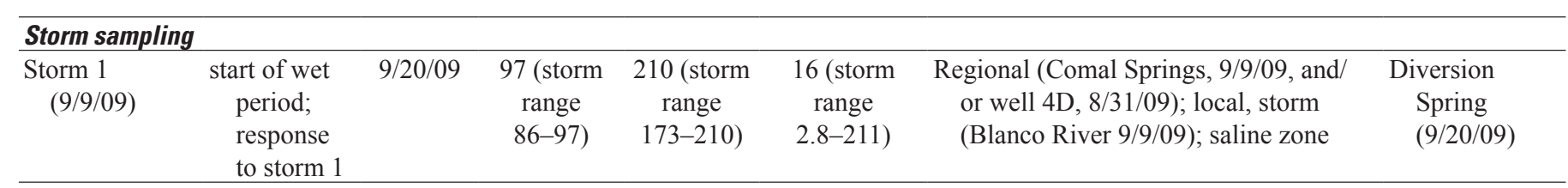

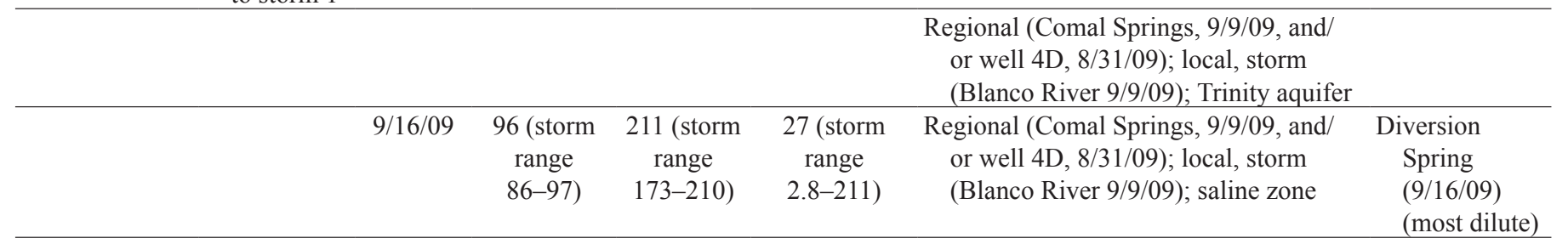

Regional (Comal Springs, 9/9/09, and/

or well 4D, 8/31/09); local, storm

(Blanco River 9/9/09); Trinity aquifer

\begin{tabular}{|c|c|c|c|c|c|c|c|}
\hline $\begin{array}{l}\text { Storm } 2 \\
(10 / 3 / 09)\end{array}$ & $\begin{array}{l}\text { wet period; } \\
\text { response } \\
\text { to storm } 2\end{array}$ & $10 / 9 / 09$ & $\begin{array}{l}142(\text { storm } \\
\text { range } \\
96-147)\end{array}$ & $\begin{array}{l}265 \text { (storm } \\
\text { range } \\
210-274)\end{array}$ & $\begin{array}{c}196(\text { storm } \\
\text { range } 21-220)\end{array}$ & $\begin{array}{l}\text { Regional (Comal Springs, 10/7/09, and/ } \\
\text { or well 4D, 10/5/09); local, storm } \\
\text { (Blanco River 10/4/09); saline zone }\end{array}$ & $\begin{array}{l}\text { Diversion } \\
\text { Spring } \\
(10 / 9 / 09) \\
\text { (most dilute) }\end{array}$ \\
\hline
\end{tabular}

Regional (Comal Springs, 10/7/09, and/

or well 4D, 10/5/09); local, storm

(Blanco River 10/4/09); Trinity aquifer

\begin{tabular}{|c|c|c|c|c|c|c|c|}
\hline $\begin{array}{l}\text { Storm } 3 \\
\qquad(9 / 7 / 10)\end{array}$ & $\begin{array}{l}\text { wet period; } \\
\text { response } \\
\text { to storm } 3\end{array}$ & $9 / 22 / 10$ & $\begin{array}{l}218 \text { (storm } \\
\text { range } \\
207-223)\end{array}$ & $\begin{array}{l}357 \text { (storm } \\
\text { range } \\
313-348)\end{array}$ & $\begin{array}{l}203 \text { (storm } \\
\text { range } \\
46-3,620)\end{array}$ & $\begin{array}{l}\text { Regional (Comal Springs, 9/8/10, and/ } \\
\text { or well 4D, 10/1/10); local, storm } \\
\text { (Blanco River 9/8/10); saline zone }\end{array}$ & $\begin{array}{l}\text { Diversion } \\
\text { Spring } \\
(9 / 22 / 10)\end{array}$ \\
\hline
\end{tabular}

Regional (Comal Springs, 9/8/10, and/ or well 4D, 10/1/10); local, storm (Blanco River 9/8/10); Trinity aquifer

$\begin{array}{cccccc}\text { 9/29/10 } & 218 \text { (storm } & 352 \text { (storm } & 159 \text { (storm } & \text { Regional (Comal Springs, 9/8/10, and/ } & \text { Diversion } \\ \text { range } & \text { range } & \text { range } & \text { or well 4D, 10/1/10); local, storm } & \text { Spring } \\ & 207-223) & 313-348) & 46-3,620) & \text { (Blanco River 9/8/10); saline zone } & (9 / 29 / 10)\end{array}$

Regional (Comal Springs, 9/8/10, and/ (most dilute)

or well 4D, 10/1/10); local, storm (Blanco River 9/8/10); Trinity aquifer

\footnotetext{
${ }^{1}$ Mineral and gas phases included for all models: calcite, dolomite, gypsum, quartz, carbon dioxide (gas), oxygen (gas), $\mathrm{CaX}_{2}$ (calcium exchange site), $\mathrm{NaX}$ (sodium exchange site); phase transfer options for dolomite and gypsum included only dissolution (no precipitation).

${ }^{2}$ Models balanced on ions included in phases, plus boron, $\mathrm{Br}$, chloride, fluoride, potassium, sodium, and strontium, unless otherwise noted.

${ }^{3}$ Composition of representative local recharge water based on samples from Blanco River at Halifax Ranch near Kyle, Texas (station number 08171290).

${ }^{4}$ Composition of representative regional flow water based on samples from Comal Spring 1 (DX-68-23-301) and well 4D (DX-68-16-707).

${ }^{5}$ Composition of regional/mineralized Trinity aquifer groundwater based on sample from well LR-67-01-813A, as discussed in text.

${ }^{6}$ Composition of regional Trinity aquifer groundwater based on sample from well DX-68-07-505 (Eagle Peak well) in Comal County, as discussed in text.
} 


\begin{tabular}{|c|c|c|c|c|c|c|c|c|c|}
\hline \multirow[b]{2}{*}{$\begin{array}{l}\text { Sample } \\
\text { collection }\end{array}$} & \multicolumn{9}{|c|}{ Model results, proportion of initial water compositions (percent) $)^{1-8}$} \\
\hline & $\begin{array}{c}\text { Local } \\
\text { re- } \\
\text { charge } \\
\text { (Blanco }^{\text {River) }}{ }^{3}\end{array}$ & $\begin{array}{l}\text { Regional- } \\
\text { flow } \\
\text { ground- } \\
\text { water } \\
\text { (Comal } \\
\text { Springs) }\end{array}$ & $\begin{array}{c}\text { Region- } \\
\text { al- } \\
\text { flow } \\
\text { ground- } \\
\text { water } \\
\text { (well } \\
\text { 4D) }\end{array}$ & $\begin{array}{l}\text { Saline- } \\
\text { zone } \\
\text { ground- } \\
\text { water }^{5}\end{array}$ & $\begin{array}{l}\text { Trinity } \\
\text { aquifer } \\
\text { ground- } \\
\text { water } \\
\text { (regional/ } \\
\text { mineral- } \\
\text { ized) }\end{array}$ & $\begin{array}{c}\text { Trinity } \\
\text { aquifer } \\
\text { ground- } \\
\text { water } \\
\text { (local) }^{7}\end{array}$ & $\begin{array}{c}\text { Num- } \\
\text { ber of } \\
\text { models } \\
\text { found, } \\
\text { minimal } \\
\text { models } \\
\text { found }^{9}\end{array}$ & $\begin{array}{c}\text { Maximum } \\
\text { fractional } \\
\text { uncertain- } \\
\text { ty in model } \\
\text { (element } \\
\text { concen- } \\
\text { trations) }\end{array}$ & Comments \\
\hline \multicolumn{10}{|c|}{ Storm sampling } \\
\hline \multirow[t]{4}{*}{$\begin{array}{l}\text { Storm } 1 \\
\quad(9 / 9 / 09)\end{array}$} & $\begin{array}{l}8.7- \\
10.2\end{array}$ & $\begin{array}{c}60.7- \\
68.1\end{array}$ & $\begin{array}{c}21.7- \\
30.6\end{array}$ & $0-0.03$ & $\mathrm{X}$ & $\mathrm{X}$ & 8,1 & 0.05 & $\begin{array}{l}\text { Storm marks transition from dry period to } \\
\text { wet period. }\end{array}$ \\
\hline & 10.6 & 67.4 & 2.1 & $X$ & 0 & 0 & 4,1 & 0.05 & $\begin{array}{l}\text { Storm marks transition from dry period to wet } \\
\text { period; no models include Trinity aquifer. }\end{array}$ \\
\hline & $\begin{array}{c}12.9- \\
13.1\end{array}$ & $\begin{array}{c}64.1- \\
65.3\end{array}$ & $\begin{array}{c}21.6- \\
23.0\end{array}$ & 0.1 & $\mathrm{X}$ & $\mathrm{X}$ & 4,1 & 0.04 & $\begin{array}{l}\text { Storm marks transition from dry period to } \\
\text { wet period. }\end{array}$ \\
\hline & 14.8 & 78.1 & 7.0 & $\mathrm{X}$ & 0 & $\begin{array}{l}0-\text { mi- } \\
\text { nor }\end{array}$ & 4,1 & 0.04 & $\begin{array}{l}\text { Storm marks transition from dry period to } \\
\text { wet period. }\end{array}$ \\
\hline $\begin{array}{l}\text { Storm } 2 \\
\quad(10 / 3 / 09)\end{array}$ & $\begin{array}{c}6.4- \\
8.9\end{array}$ & $\begin{array}{c}91.0- \\
93.6\end{array}$ & 0 & 0 & $\mathrm{X}$ & $\mathrm{X}$ & 5,1 & 0.06 & No models include saline zone. \\
\hline & $0-1.5$ & $98.3-100$ & $0-0.3$ & $\mathrm{X}$ & 0 & $0-0.5$ & 19,1 & 0.09 & Relatively high uncertainty needed. \\
\hline
\end{tabular}

\begin{tabular}{|c|c|c|c|c|c|c|c|c|c|}
\hline \multirow[t]{2}{*}{$\begin{array}{l}\text { Storm } 3 \\
\qquad(9 / 7 / 10)\end{array}$} & $0-1.6$ & $\begin{array}{l}19.0- \\
83.1\end{array}$ & $\begin{array}{c}16.8- \\
79.9\end{array}$ & $0.1-0.2$ & $X$ & $X$ & 10,2 & 0.05 & \\
\hline & $0-2.7$ & $\begin{array}{c}15.2- \\
54.3\end{array}$ & $\begin{array}{c}45.1- \\
84.6\end{array}$ & 0.1 & $X$ & X & 12,4 & 0.05 & \\
\hline
\end{tabular}

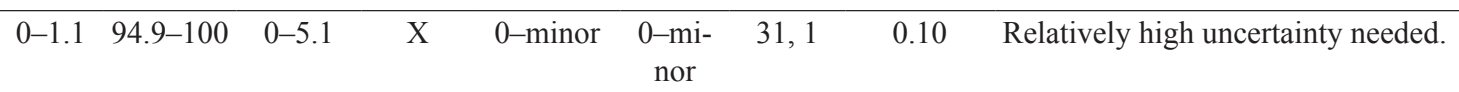

${ }^{7}$ Composition of local Trinity aquifer groundwater based on sample from well LR-68-08-502 (Burns well) in Hays County, as discussed in text.

${ }^{8}$ Composition of San Marcos Springs based on samples from Deep (LR-67-01-819), Diversion (LR-67-01-825), or Weissmuller (LR-67-01-820) Springs orifices.

${ }^{9}$ Minimal model is one with a minimum number of phases; that is, none of the phases can be removed and still obtain a feasible model (Parkhurst and Appelo, 1999).

${ }^{10}$ For Blanco River at Wimberley, Tex. (station number 08171000); station at Halifax Ranch (08171290) installed $12 / 2008$ with data available beginning $12 / 19 / 2008$. 
Four sampling periods during the wet period were selected for inverse modeling, which included a large range in hydrologic conditions (table 6). One of the modeled sampling periods (February 2010) coincided with an unsampled storm event (January/February 2010) (tables 4 and 6; fig. 19D). A similar modeling approach was used as for sampling periods during the dry period: regional groundwater flow endmembers, the local recharge endmember, and either the saline-zone groundwater or Trinity aquifer endmembers were mixed to approximate the composition of spring discharge from Deep, Diversion, and, when sampled, Weissmuller Springs. Similar to those for the dry period, inverse modeling results for the wet period indicate that the composition of discharge at San Marcos Springs is dominated by regional groundwater flow that has mixed with a small (up to 0.2 percent) component of saline-zone groundwater. Also similar to those for the dry period, some wet-period models were consistent with mixing of regional groundwater flow with a small component of Trinity aquifer groundwater (up to 1.3 percent); however, model uncertainties were typically larger for mixtures that included the Trinity aquifer relative to those that included the saline zone. As a result, although mixing with the Trinity aquifer is possible, modeling results indicate that mixing with water from the saline zone is a better geochemical fit and more hydrologically plausible.

Although dominated by regional groundwater flow, model results for the wet period generally included a component of local recharge, which ranged from 0 to 28.9 percent. For each modeled routine sampling date (dry and wet periods), the modeled range of the proportion of local recharge (for all models that included saline-zone groundwater only, not Trinity aquifer groundwater) was compared with hydrologic conditions to evaluate potential changes in response to hydrologic conditions. The median value (for the midpoint of the modeled range of the proportion of local recharge for each modeled date) for the dry period was less than that for the wet period for both Deep (3.1 and 8.0 percent, respectively) and Diversion (1.9 and 10.9 percent, respectively) Springs, which indicates that the proportion of local stream recharge contributing to San Marcos Springs likely increased from the dry period to the wet period. The difference between the dry and wet periods, however, was statistically significant for only Diversion Spring (not for Deep Spring; Weissmuller Spring was not sampled during the dry period and therefore was not compared). The modeled proportion of local recharge tended to be larger with larger spring discharge values, although the relation was not statistically significant for either Deep or Diversion Springs (fig. 23). The relation was statistically significant, however, when all values for Deep, Diversion, and Weissmuller Springs were considered collectively. The highest values for the modeled proportion of surface water (larger than 20 percent) were associated with the northern spring orifices (Diversion and Weissmuller) and corresponded to the same sampling date (December 1, 2010) (table 6), but not to the wettest hydrologic conditions. These higher values are further considered in the section "Endmember Mixing Using Conservative Tracers."

In summary, inverse modeling results for routine samples indicate that San Marcos Springs discharge includes a small component of local recharge from the Blanco River. The component of local recharge is typically less than 10 percent but might be as much as $20-30$ percent under some conditions; model results that indicated a larger component of local stream recharge were generally associated with wetter hydrologic conditions (fig. 23; table 6). Model results for the dry period with a relatively large (that is, $>5 \%$ ) component of local recharge are considered hydrologically implausible on the basis of hydrologic conditions and nominal streamflow and associated aquifer recharge. Inverse modeling results for routine samples indicate that San Marcos Springs discharge includes a small component of more saline groundwater. As a proportion of spring discharge, the percentage of salinezone groundwater from model results was relatively constant (for models considering saline-zone groundwater and not Trinity aquifer groundwater) (table 6). As a result, as spring discharge increased, the associated rate of discharge attributed to saline-zone groundwater also increased; for all model results, however, estimates of the saline-zone groundwater contribution were less than $0.5 \mathrm{ft}^{3} / \mathrm{s}$.

\section{Modeling Based on Storm Sampling}

For storms 1-3, the geochemical composition of Diversion Spring (the San Marcos Springs orifice that was more responsive to changes in hydrologic conditions) in response to the storms was modeled (table 6). Similar to modeling for routine samples, surface-water samples collected during storm events were used to represent the local recharge component, and the most recent samples collected from Comal Springs and well 4D were used to represent the regional groundwater flow component. The most dilute sample collected from Diversion Spring in response to each storm was modeled on the basis of the hypothesis that it might plausibly represent discharge associated with the maximum contribution of dilute surface-water recharge. For storms 1 and 3, two additional samples collected from Diversion Spring were also modeled. Inverse modeling results for storms 1-3 indicate that the proportion of local recharge contributing to Diversion Spring ranged from 0 to 13.1 percent (table 6). Note that this discussion is based on models including saline-zone groundwater but not Trinity aquifer groundwater (the proportion of the local recharge contribution for models incorporating Trinity aquifer groundwater was similar, from 0 to 14.8 percent). The modeled local recharge contribution range is within that modeled for routine samples and is consistent with little geochemical variability at San Marcos Springs in response to individual storm and recharge events (figs. 13 and 19); these results indicate that San Marcos 


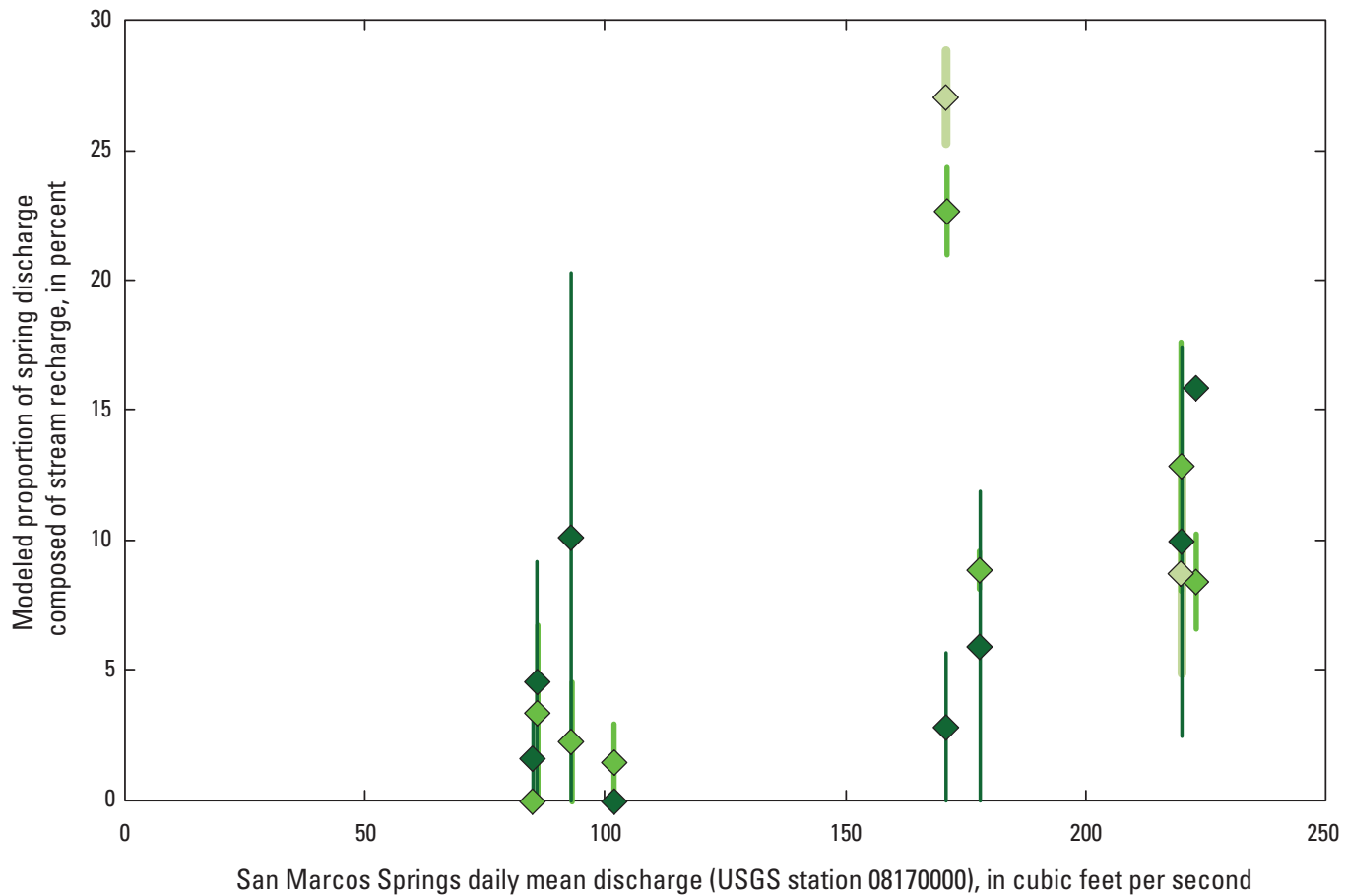

\section{EXPLANATION}

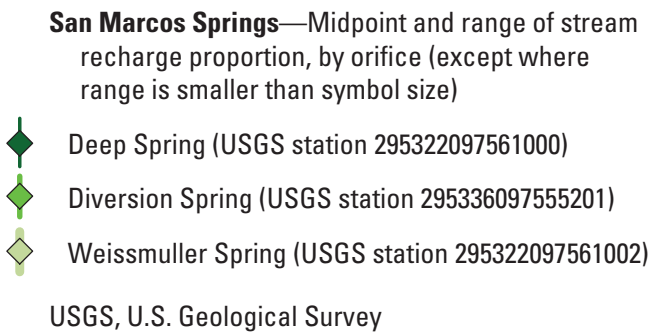

Figure 23 Relation between discharge at San Marcos Springs (U.S. Geological Survey station 08170000 San Marcos Springs at San Marcos, Texas) and the modeled proportion of discharge at Deep, Diversion, and Weissmuller Springs (San Marcos Springs orifices) that is composed of stream recharge from the Blanco River based on PHREEOC (Parkhurst and Appelo, 1999) inverse modeling results (detailed in table 6). For model results that included a range of stream recharge proportions, the midpoint is shown and used for statistical analysis (included in the range for dry period conditions are model results that excluded stream recharge; thus, the minimum value for local recharge for these conditions was 0 ).

Springs is not notably affected by storm recharge from local recharge sources moving rapidly through transmissive flow paths. The proportion of local recharge contributing to Diversion Spring was largest for storm 1, which marked the transition from the dry period to the wet period and was preceded by the driest antecedent moisture conditions during the study (table 3 ) (models including Trinity aquifer groundwater also had the largest proportion of local recharge contribution for storm 1). The proportion of modeled local recharge decreased from storm 1 to storm 3 ; storm 3 was the largest storm but had the smallest proportion.

\section{Endmember Mixing Using Conservative Tracers}

As noted earlier in the section "Rainfall Characteristics," stable isotope values for rain samples collected during storm 1 and, in particular, storm 3 (tropical storm Hermine) were distinctive and isotopically light relative to other rain samples. As a result, stable isotope values might provide a useful geochemical tracer of recent recharge to the aquifer. Deuterium isotopes $(\delta \mathrm{D})$ and $\mathrm{Cl}$ are conservative tracers that can be used to distinguish mixing processes when endmembers are chemically distinct. Both $\delta \mathrm{D}$ values and $\mathrm{Cl}$ 
concentrations tended to markedly decrease in the streams in response to storms (figs. 12 and 13). Storm 1 marked the transition from the dry period to the wet period; storm 3 was the largest storm that occurred during the study period. Isotopically light values for rainwater during storms 1 and 3 , and in particular for storm 3 (fig. 9), were reflected in the composition of surface-water samples collected in response to storm 3, which were also isotopically light relative to other surface-water samples (figs. 12 and 13). Local recharge to the Edwards aquifer and to wells and springs affected by recent recharge (via quick flow) in response to storm 3 should reflect these light isotopic values and provide a tracer of recent recharge.

Several groundwater wells appear to have been affected by mixing with recent recharge from storm 3 (fig. 15). For example, the $\delta \mathrm{D}$ value for groundwater from the Solar well collected about 3 weeks after storm 3 was -28.9 per mil, a 4.3 per mil drop from the previous sample collected before storm 3 (fig. 15). After 4 additional weeks (October 28, 2010, about 7 weeks after storm 3 ), the $\delta \mathrm{D}$ value for groundwater from the Solar well had largely recovered and had risen to -25.8 per mil, about 1 per mil lower than the prestorm value. This decrease and subsequent rise in $\delta \mathrm{D}$ values, like a breakthrough curve, is indicative of a pulse of isotopically light recharge water mixing with groundwater. Mixing calculations based on a storm 3 recharge endmember (with a $\delta \mathrm{D}$ value of -79.5 per mil, the value measured for the Blanco River during storm 3 [Crow, 2012]) and the prestorm value at the Solar well indicate that a mixture including about 8 percent of recharge from the Blanco River would account for the change in $\delta \mathrm{D}$ at the Solar well in response to local recharge from storm 3. Other geochemical constituents, however, indicate that the Solar well is affected by mixing with more saline groundwater during the wet period (fig. 15), as discussed earlier in the section Geochemical Variability Associated with Routine Sampling. Other groundwater wells (for example, Neff and TSU-West Campus) showed similar but more muted responses to storm 3 , with decreases of about 2 per mil in $\delta \mathrm{D}$ values (fig. 15). These small decreases in $\delta \mathrm{D}$ values (the analytical uncertainty of $\delta \mathrm{D}$ measurements is \pm 1 per mil) might be indicative of mixing with a minor component of isotopically light recent recharge.

Samples collected from the three orifices of San Marcos Springs (Deep, Diversion, and Weissmuller Springs) in response to storms $1-3$ showed little variability in $\delta \mathrm{D}$ values or $\mathrm{Cl}$ concentrations (fig. 13), indicating that spring discharge following the storms was not substantially affected by mixing with local surface-water recharge. Effects of mixing with surface-water recharge would likely be most evident for storm 3 , for which stable isotope values in surface-water recharge showed the largest variation (figs. 12 and 13). In response to storm 3, $\delta$ D values at San Marcos Springs showed little variability; the largest change in $\delta \mathrm{D}$ values was measured in samples from Diversion Spring: the prestorm $\delta \mathrm{D}$ value was -21.6 per mil; $\delta \mathrm{D}$ decreased by 1.3 per mil (to -22.9 per mil) 2 days after the onset of storm 3 , returned to a value
( -21.8 per mil) similar to the prestorm value 4 days after the onset of storm 3, and dropped to -24.0 per mil 3 months after the onset of storm 3 (a 2.4-per mil decrease from the prestorm value). A decrease of 1.3 per mil would be accounted for by mixing prestorm spring discharge with about 2 percent of the Blanco River endmember collected during storm 3 (with a $\delta \mathrm{D}$ value of -79.5 per mil); a 2.4-per mil decrease would be accounted for by mixing prestorm spring discharge with about 4 percent of the Blanco River endmember. Similar to those from Diversion Spring, samples collected from Weissmuller Spring showed little change in $\delta \mathrm{D}$ values in the weeks after storm $3 ; 3$ months after storm 3 , the $\delta \mathrm{D}$ value for Weissmuller Spring had decreased by 1.7 per mil (which would be accounted for by mixing prestorm spring discharge with about 2 percent of the Blanco River endmember). These proportions of local recharge based on isotopic mixing for storm 3 are similar to the range of values determined by using PHREEQC inverse modeling ( $0-2.7$ percent) for storm 3 . It should be noted, however, that the measured changes in $\delta \mathrm{D}$ values for the San Marcos Springs orifices are within or close to analytical uncertainty ( \pm 1 per mil), and thus the changes in response to storm 3 should be interpreted with caution.

A two-component mass-balance mixing model was developed on the basis of the conservative tracers $\delta \mathrm{D}$ and $\mathrm{Cl}$ to estimate the proportion of local (stream) recharge to spring discharge in response to storm 3. Endmember water compositions were the surface-water recharge endmember (based on the storm sample collected from Blanco at Halifax in response to storm 3 ) and the springwater sample collected preceding the storm. The compositions of Deep, Diversion, Weissmuller, and Hueco Spring A were evaluated in response to storm 3 (fig. 24). The model estimated mixing in 10 percent increments. Model results were also compared with spring samples collected for several months after storm 3 (fig. 24). Mixing-model results indicate that recharge from the Blanco River was a minor (less than 10 percent) component of San Marcos Springs discharge for Deep, Diversion, and Weissmuller Springs both immediately following storm 3 and for up to 3 months after storm 3; the proportion of Blanco River recharge increased slowly during the subsequent 3 months following the storm, approaching a maximum value of 10 percent at Diversion and Weissmuller (fig. 24). These results indicate that a small amount (less than 10 percent) of local recharge might contribute to San Marcos Springs (specifically, Diversion and Weissmuller Springs) under some hydrologic conditions but that such recharge travels slowly and is not moving through highly transmissive flow paths. The contribution of local recharge following storm 3 based on the two-component mixing model is less than that estimated by using PHREEQC (table 6; results for Nov./Dec. 2010). The two-component mixing model results place further constraints on estimates of local recharge sources from PHREEQC inverse models and indicate that the proportion of local recharge is likely lower than that estimated by PHREEQC for this time period. 

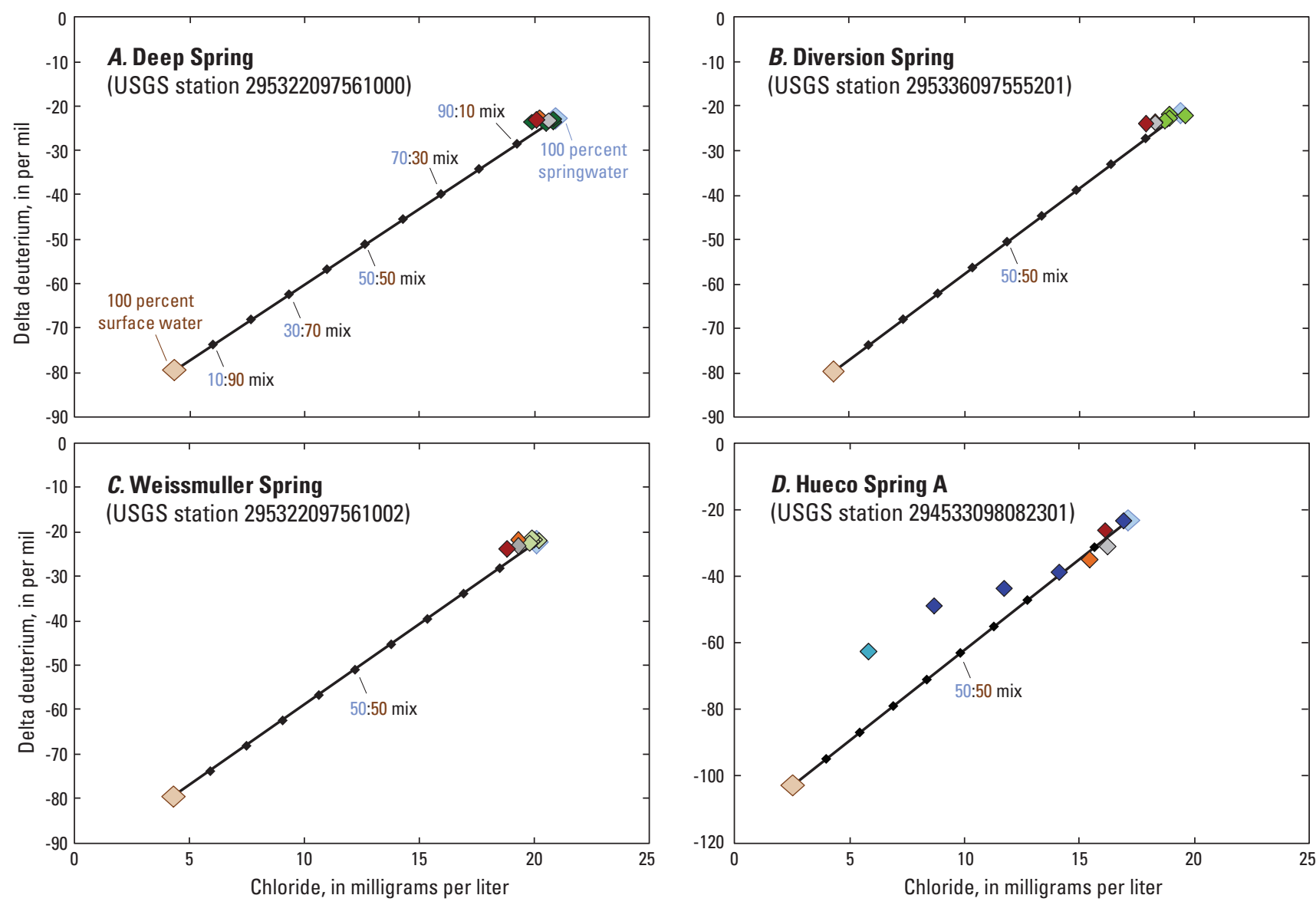

EXPLANATION

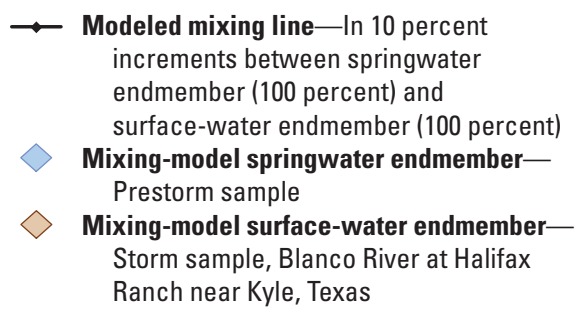

Sample collected in response to storm 3

$\checkmark$ San Marcos Springs_-Deep Spring

$\diamond$ San Marcos Springs-Diversion Spring

$\diamond$ San Marcos Springs-Weismuller Spring

$\diamond$ Hueco Spring $A$

$\diamond$ Hueco Spring A, modeled sample composition (described in report section "Endmember Mixing Using Conservative Tracers")

\section{Routine sample collected after storm 3, by date \\ $\diamond$ September 29, 2010 \\ $\diamond$ October 29, 2010 \\ $\checkmark$ December 1, 2010}

USGS, U.S. Geological Survey

Figure 24. Relation between chloride concentration and deuterium isotopes for two-component mixing models showing proportional mixing between surface-water (stream recharge) and springwater endmembers and for samples collected in response to and subsequent to storm 3 (September 2010). A, Deep Spring (San Marcos Springs orifice). B, Diversion Spring (San Marcos Springs orifice). C, Weissmuller Spring (San Marcos Springs orifice). D, Hueco Spring A (Hueco Springs).

The modeled response at San Marcos Springs using conservative tracers is notably in contrast with the response at Hueco Springs following storm 3, where, 2 days after the onset of that storm, $\delta \mathrm{D}$ values dropped from -23.9 (prestorm) to a low of -62.7 , a drop of 38.8 per mil, and then gradually returned to near-prestorm values over the subsequent 3 months (fig. 18). Concentrations of $\mathrm{Cl}$ at Hueco Spring A dropped from a prestorm value of $17.2 \mathrm{mg} / \mathrm{L}$ to a low of $5.88 \mathrm{mg} / \mathrm{L}$. Mixing models for the composition of Hueco Spring A in response to storm 3 , based on (1) the prestorm composition of
Hueco Spring A (from the sample collected on September 6, 2010) and (2) the composition of Cibolo Creek in response to storm 3, indicate that the composition of Hueco Spring A following storm 3 was dominated (>50 percent) by recent surface-water recharge (fig. 24). Mixing model results for Hueco Spring A also indicate that other sources might contribute to Hueco Springs discharge as sample results do not fall directly on the mixing line between these two endmembers. 


\section{Synthesis of the Origin and Characteristics of Discharge at San Marcos Springs}

The wide range of hydrologic conditions that occurred during this 25-month study - and corresponding changes in surface-water, groundwater and spring discharge, physicochemical properties, and geochemistry-provides insight into the origin of the water discharged from San Marcos Springs.

\section{Factors Affecting Local Recharge Sources}

Previous studies have hypothesized that discharge at San Marcos Springs might include contributions of recharge from nearby recharging streams, including the Guadalupe River, Cibolo Creek, Dry Comal Creek, Sink Creek, Purgatory Creek, York Creek, Alligator Creek, and, in particular, the Blanco River (Ogden and others, 1985a, 1985b, 1986; Johnson and Schindel, 2008). Estimates of annual groundwater recharge to the regional Edwards aquifer indicate that the Blanco River Basin is not a major recharge contributor relative to other recharge basins. The long-term (1934-2009) average annual recharge estimate for the Blanco River Basin, as a proportion of total estimated aquifer recharge, is 7.1 percent of annual groundwater recharge (Edwards Aquifer Authority, 2010). Nonetheless, with a historical median recharge estimate of 35,200 acre feet per year (Edwards Aquifer Authority, 2010), the Blanco River might be a substantial local recharge source. Temporal correspondence and similar flashy behavior in response to local storms have been previously noted in comparisons of discharge of the Blanco River and San Marcos Springs and have been interpreted to indicate that the Blanco River might be a source of discharge at San Marcos Springs (LBG-Guyton Associates, 2004; Johnson and Schindel, 2008). Daily mean recharge estimates for the Blanco River computed for this study and daily mean discharge at San Marcos Springs show both similarities and differences (fig. 25); values are correlated with a Kendall's tau of 0.61. Similar to many surface-water features in the region, the Blanco River has large responses in recharge estimates to rain events, while discharge responses at San Marcos Springs tend to be more attenuated (fig. 25). San Marcos Springs discharge during the study period is similarly correlated with recharge estimates for other potential local recharge sources, namely Cibolo Creek and Dry Comal Creek (Kendall's tau of 0.59 and 0.70, respectively), as well as with discharge at Comal Springs, an indicator of regional hydrologic conditions (Kendall's tau of 0.79 ). These correlations, however, are not necessarily indicative of the effects of local recharge. It is important to note that both the regional and local aquifer systems respond to regional rainfall and recharge events. For example, discharge at Comal Springs is similarly correlated with local upgradient recharge sources such as the Blanco River (Kendall's tau with estimated Blanco River recharge is 0.55 ), which is not a hydrologically likely source of recharge to Comal Springs. These results indicate that it is difficult to distinguish local and regional recharge; recharge events often occur throughout the regional aquifer system, and individual basin contributions are not readily distinguishable solely on the basis of temporal variations in spring discharge.

The Guadalupe River has been hypothesized as a possible source of discharge at San Marcos Springs (Johnson and Schindel, 2008). As discussed in the section Climatic and Hydrologic Conditions, the Guadalupe River likely does not contribute substantial recharge to the Edwards aquifer (fig. 8 ), which is consistent with previous interpretations of the small role of the Guadalupe River in recharging the Edwards aquifer (Puente, 1978; Edwards Aquifer Authority, 2010). In response to a large and geographically isolated flow event on the Guadalupe River and Dry Comal Creek on June 9, 2010, estimated recharge to the Edwards aquifer from Dry Comal Creek was large (fig. 7), whereas the Guadalupe River was gaining (that is, not contributing recharge) (fig. 8). At San Marcos Springs following this event there was no notable response in physicochemical properties (fig. 19), which indicates little contribution to San Marcos Springs discharge likely occurred from these streams.

The short time periods of flow and the relatively minor amounts of flow at Sink Creek and Purgatory Creek over the range of hydrologic conditions that occurred during the study indicate that these ephemeral streams did not contribute substantial recharge to the Edwards aquifer or to San Marcos Springs. Although streamflow was not measured at York and Alligator Creeks, similar to Sink and Purgatory Creeks they are relatively minor ephemeral streams and likely did not contribute substantial recharge to the Edwards aquifer or to San Marcos Springs during this study.

Other potential sources of discharge from San Marcos Springs include groundwater from the Trinity aquifer and from the saline zone, both of which are generally more saline in composition than is Edwards aquifer groundwater or recharge from surface water. Specific conductance values were consistently higher at San Marcos Springs (median values of 613,595 , and $595 \mu \mathrm{S} / \mathrm{cm}$ for Deep, Diversion, and Weissmuller Springs, respectively) than at Comal Springs (median value of $558 \mu \mathrm{S} / \mathrm{cm}$ ) (fig. 18) and were also consistently higher than the median value for confined groundwater from the regional aquifer $(525 \mu \mathrm{S} / \mathrm{cm}$; Musgrove and others, 2010). Higher specific conductance values at San Marcos Springs are consistent with modeling results that indicate that San Marcos Springs is affected by the influx of a small component of more saline groundwater (table 6). 


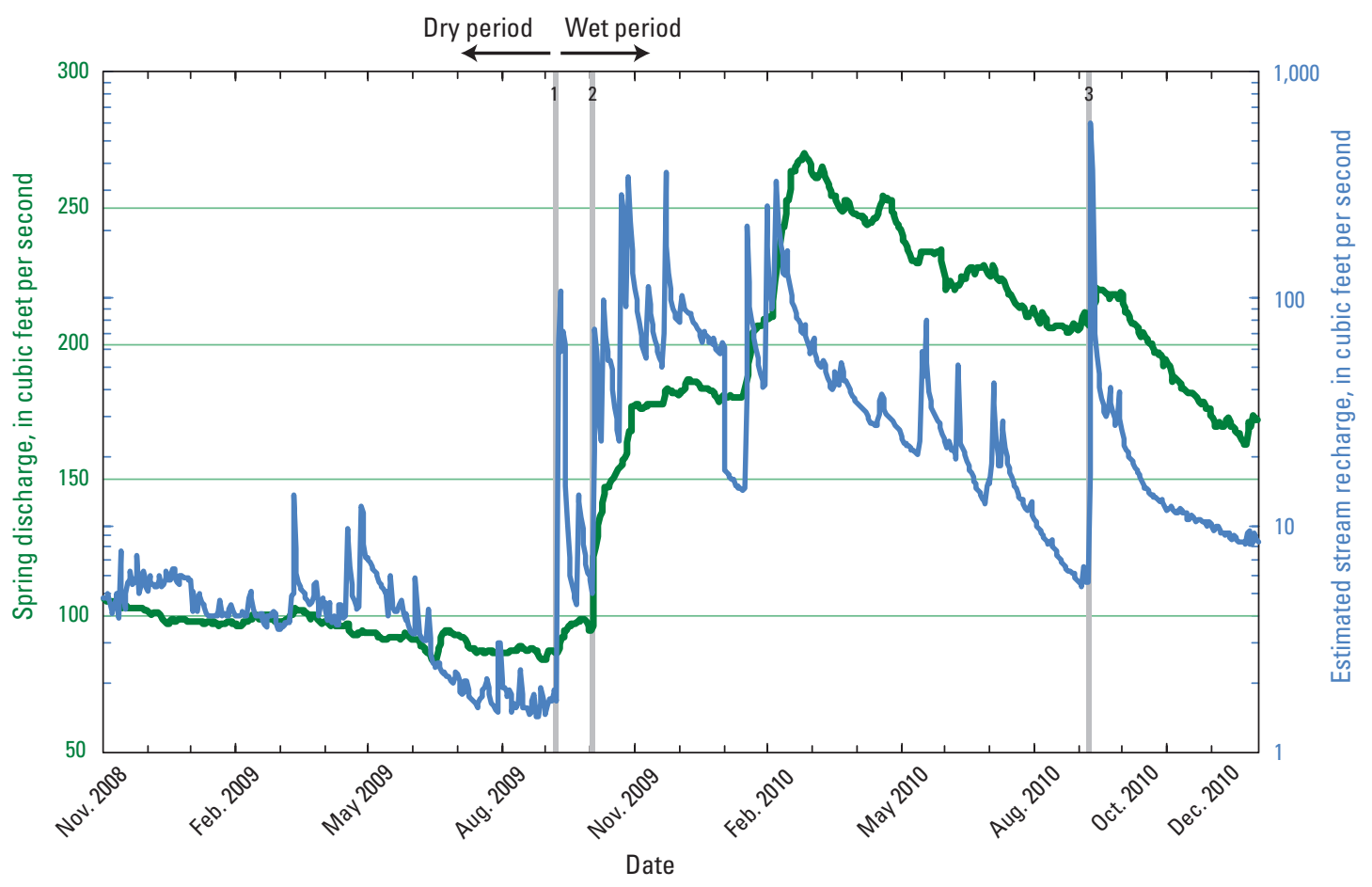

EXPLANATION

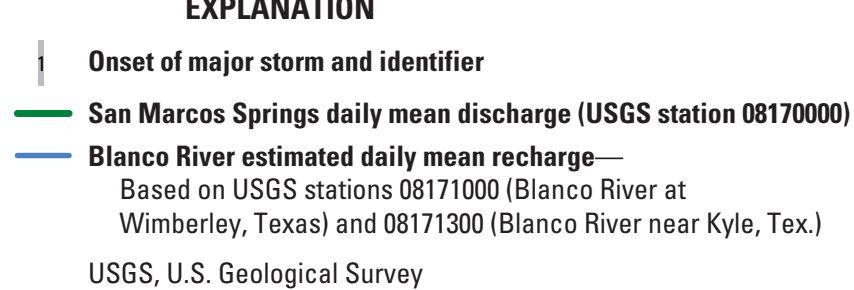

Figure 25. Time series (November 2008-December 2010) of San Marcos Springs daily mean discharge (U.S. Geological Survey station 08170000 San Marcos Springs at San Marcos, Texas) and estimated daily mean recharge to the Edwards aquifer from the Blanco River, south-central Texas.

\section{Relation of Spring Geochemistry to Hydrologic Conditions}

Differences in the geochemistry of Comal Springs, Hueco Springs, and San Marcos Springs from the dry period to the wet period provide information on flow paths and sources of spring discharge. During the dry period, little recharge was occurring regionally or locally, and spring discharge from all of the springs predominantly reflects draining of matrix groundwater. There were, however, some notable geochemical differences between the springs during the dry period that likely reflect differences in flow paths and sources of spring discharge. The geochemistry of Hueco Springs during the dry period was different from both Comal Springs and San Marcos Springs for numerous constituents (fig. 18; table 5), with higher $\mathrm{Mg}, \mathrm{SO}_{4}, \mathrm{~B}$, and $\mathrm{F}$ concentrations and $\mathrm{Mg}$ / $\mathrm{Ca}$ ratios; higher $\delta \mathrm{D}$ and $\delta^{13} \mathrm{C}$ values; and lower $\mathrm{NO}_{3}+\mathrm{NO}_{2}$ concentrations. Hueco Springs discharges from the upthrown side of the Hueco Springs Fault Block (Johnson and Schindel, 2008) (fig. 2) and thus is likely supplied by different flow paths than are Comal or San Marcos Springs. Unlike that of Comal and San Marcos Springs, the geochemistry of Hueco Springs discharge varied notably through the dry period for some constituents. For example, at Hueco Springs through the dry period, water temperature increased; $\mathrm{Cl}, \mathrm{Na}, \mathrm{Br}$, and $\mathrm{B}$ concentrations and $\mathrm{Mg} / \mathrm{Ca}$ ratios increased; and $\delta \mathrm{D}$ values 
increased. The increases in values of conservative constituents such as $\mathrm{Cl}$ and $\delta \mathrm{D}$ are consistent with evaporation of recharge sources supplying Hueco Springs. Stable isotope values for streams in the study area and Hueco Springs during the dry period diverge from the global and local meteoric water lines, which is consistent with evaporation (fig. 26).

Comal Springs and San Marcos Springs had generally similar geochemistry during the dry period (fig. 18), consistent with similar regional flow paths supplying both springs. Results of geochemical modeling support this hypothesis, indicating that discharge at San Marcos Springs during the dry period was dominated by regional groundwater flow (table 6). Nonetheless, Comal Springs had higher water temperatures and higher $\mathrm{Sr}$ and $\mathrm{NO}_{3}+\mathrm{NO}_{2}$ concentrations than did either Deep or Diversion Springs. These results indicate that San Marcos Springs was influenced by additional discharge sources with lower $\mathrm{Sr}$ and $\mathrm{NO}_{3}+\mathrm{NO}_{2}$ concentrations and lower water temperatures. Well $4 \mathrm{D}$, located between Comal Springs and San Marcos Springs in the Comal Springs Fault Block and likely along regional flow paths that supply San Marcos Springs, also had lower temperatures and lower $\mathrm{Sr}$ and $\mathrm{NO}_{3}+\mathrm{NO}_{2}$ concentrations in the dry period than did Comal Springs, with values closer to San Marcos Springs (figs. 15 and 18; table 5). Differences in the geochemistry of Comal Springs and well 4D indicate that there is some variability in regional flow paths, which is consistent with previous studies such as Otero (2007). Geochemical modeling results indicate that mixing of these regional flow paths (represented by the composition of Comal Spring 1 and well 4D) largely accounts for the composition of San Marcos Springs during the dry period. The geochemistry of Deep and Diversion Springs during the dry period was similar, although some differences indicate that Deep Spring was more influenced by mixing with a component of saline groundwater: Deep Spring had slightly higher specific conductance values and higher $\mathrm{Cl}, \mathrm{Na}, \mathrm{SO}_{4}, \mathrm{Sr}$, and $\mathrm{B}$ concentrations (table 5; fig. 18). Geochemical modeling results indicate that, during the dry period, discharge from Deep and Diversion Springs included a minor component ( $<1$ percent) of saline groundwater (table 6 ).

Changes in hydrologic conditions that occurred at the beginning of the wet period, as evidenced by changes in estimated aquifer recharge and water-level altitudes, resulted in large changes in discharge from all of the studied springs (table 5). At Hueco Springs, increases in discharge during the wet period were accompanied by large changes in geochemistry (table 5; fig. 18). At Comal and San Marcos Springs, changes in geochemistry were relatively minor with fewer significant differences or smaller ranges of variability between the dry and wet periods (table 5; fig. 18) and mostly nominal changes in response to storms (fig. 13).

The source of recharge and the length of flow paths supplying spring discharge are key factors that affect the chemical variability of spring discharge (Scanlon and Thrailkill, 1987; White, 1999; Vesper and White, 2004). The characterization of karst springs ranges from those with considerable variations in springwater chemistry, resulting from higher proportions of quick flow through conduits, to those with little to no variations in springwater chemistry despite fluctuations in discharge, resulting from lower proportions of quick flow and higher proportions of slow flow (Shuster and White, 1971; Atkinson, 1977). Relations between respective spring discharge and results for selected geochemical constituents for Comal, Hueco, and San Marcos Springs (table 7; fig. 27) indicate that Comal and Hueco Springs are representative of two endmember spring types for major Edwards aquifer springs: Hueco Springs discharge is dominated by locally sourced conduit flow (quick flow), and Comal Springs discharge is dominated by more regionally sourced flow paths (slow flow). These endmember spring types are consistent with a measure of spring "flashiness" defined by the ratio of maximum discharge to average discharge (White, 1988): for the overlapping period of record (2002-2010) this ratio is 1.5 for Comal Springs and 2.8 for Hueco Springs. The ratio for San Marcos Springs is intermediate, with a value of 2.2. Additionally, these endmember spring types are consistent with time-series results of geochemical variability for Hueco Springs and Comal Springs (fig. 18). The geochemistry of discharge at Hueco Springs is highly variable in time (fig. 18) and shows distinct and rapid changes in response to local rainfall and recharge events (fig. 13). Geochemical variability of Hueco Springs discharge for numerous selected constituents (19 of 24) was significantly correlated with changes in hydrologic conditions as represented by changes in spring discharge (table 7). In contrast, the geochemistry of discharge at Comal Springs varied little throughout the study period (fig. 18), including in response to storms (fig. 13). The geochemical variability of Comal Springs discharge was significantly correlated with changes in spring discharge for few constituents (5 of 24) (table 7).

At San Marcos Springs, Deep and Diversion Springs responded differently to changes in hydrologic conditions (table 7). The response at Diversion Spring was similar to that at Hueco Springs in that the majority of selected geochemical constituents (19 of 24) showed a significant correlation with spring discharge (table 7). The response at Deep Spring was intermediate between Diversion Spring and Comal Springs; Deep Spring was less responsive to changes in hydrologic conditions and more similar to Comal Springs, with 10 of 24 selected geochemical constituents showing a significant correlation with spring discharge (table 7). These results indicate that Deep Spring was not strongly influenced by changes in hydrologic conditions; similar to Comal Springs, discharge at Deep Spring is likely dominated by regional flow paths.

Although geochemical variability at Diversion Spring was correlated with discharge for the same number of constituents as at Hueco Springs, there were several notable differences in this comparison of Diversion Spring and Hueco Springs. First, the range of variability for most geochemical constituents was much less at Diversion Spring relative to Hueco Springs (fig. 27; table 5). 

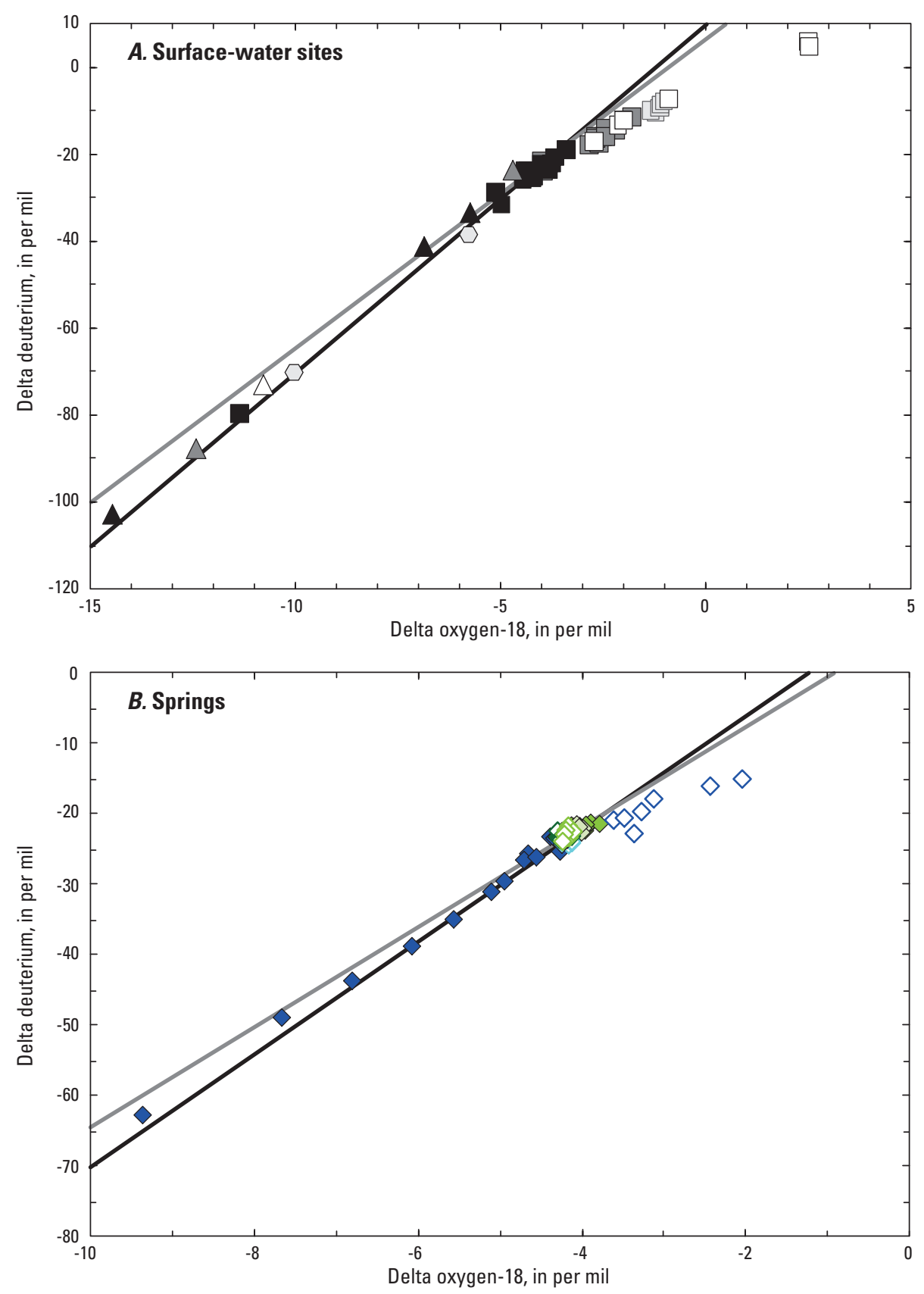

Global meteoric water line (Craig, 1961)

Local meteoric water line (Pape and others, 2010)

Stream sample, by surface-water site (table 1) and period

Guadalupe River at River Road near Sattler, Texas-Dry period

$\square \quad$ Guadalupe River at River Road near Sattler, Tex.-Wet period

\section{EXPLANATION}

$\square$ Blanco River at Halifax Ranch near Kyle, Tex.-Dry period

Blanco River at Halifax Ranch near Kyle, Tex.-Wet period

$\square$ Blanco River near Kyle, Tex.

$\triangle$ Cibolo Creek at Farm Road 1863 below Bulverde, Tex.

$\triangle$ Sink Creek near San Marcos, Tex.

$\triangle$ Purgatory Creek at Mountain High Drive near San Marcos, Tex.
Spring sample, by orifice (table 1) and period

$\diamond$ Deep Spring—Dry period

$\diamond$ Deep Spring-Wet period

$\diamond$ Diversion Spring-Dry period

$\diamond$ Diversion Spring-Wet period

$\diamond$ Weismuller Spring-Wet period

$\diamond$ Comal Spring 1-Dry period

$\diamond$ Comal Spring 1-Wet period

$\diamond$ Hueco Spring A-Dry period

$\checkmark$ Hueco Spring A-Wet period

Figure 26. Relation between deuterium and oxygen isotopes for surface-water and spring samples, south-central Texas (November 2008-December 2010). A, Surface-water sites. B, Comal Spring 1, Hueco Spring A, and San Marcos Springs orifices (Deep, Diversion, and Weissmuller Springs). Local (Pape and others, 2010) and global (Craig, 1961) meteoric water lines are shown for comparison. 
Table 7. Statistical relations for selected geochemical constituents with spring discharge for San Marcos Springs (Deep, Diversion, and Weissmuller Springs), Comal Springs, and Hueco Springs, south-central Texas (November 2008-December 2010).

[ns, not statistically significant based on a p-value of $0.05 ; \mathrm{NO}_{3}+\mathrm{NO}_{2}$, nitrate plus nitrite, as nitrogen; $\delta^{13} \mathrm{C}$, delta carbon- $13 ;{ }^{87} \mathrm{Sr} /{ }^{86} \mathrm{Sr}$, strontium- $87 / \mathrm{strontium}-86$ isotopic ratio; $\mathrm{Mg} / \mathrm{Ca}$, magnesium to calcium molar ratio, $\mathrm{Sr} / \mathrm{Ca} \times 10^{3}$, strontium to calcium molar ratio x 1,000$]$

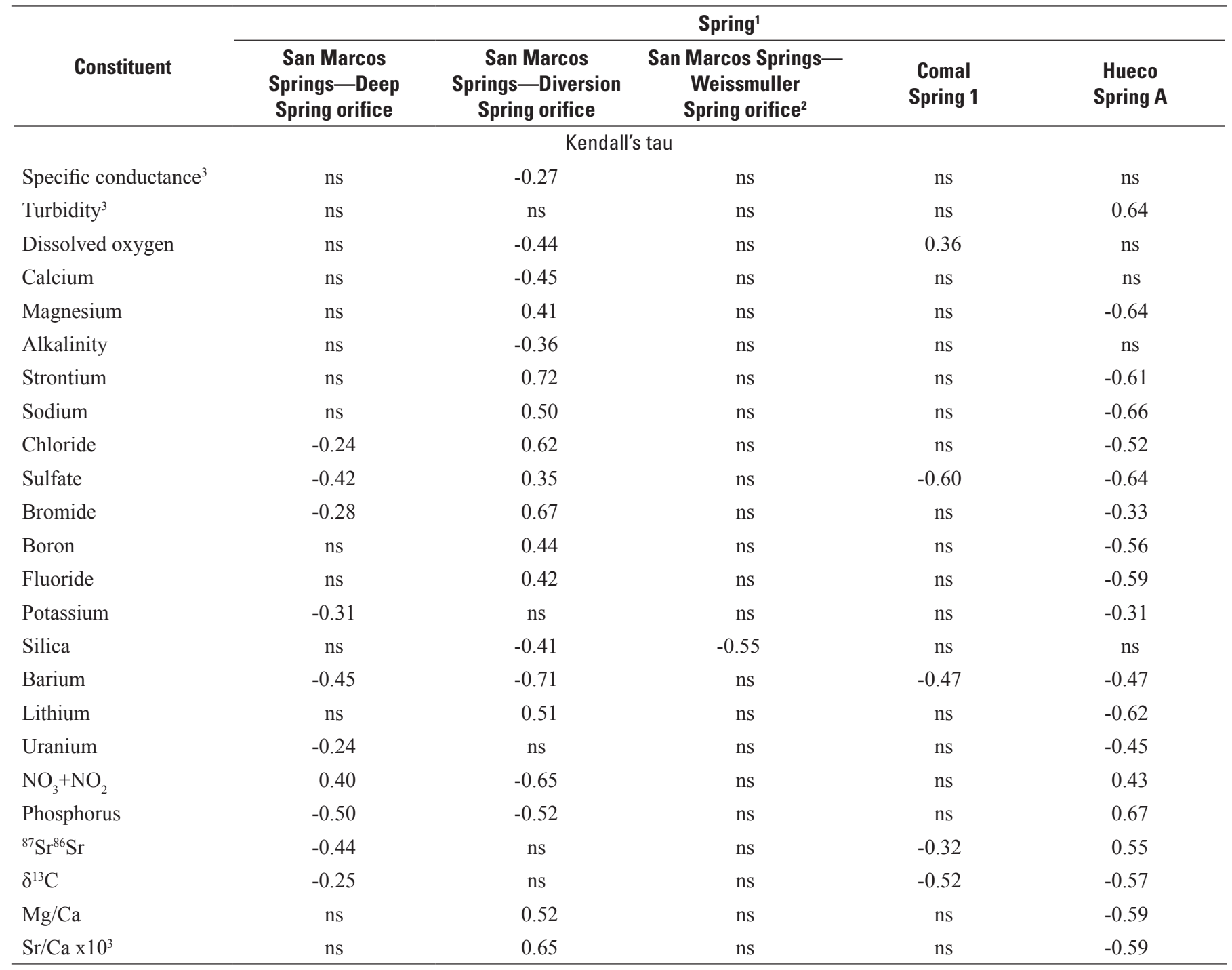

${ }^{1}$ See table 1 for complete U.S. Geological Survey station names and numbers.

${ }^{2}$ Weissmuller sampled only during the wet period (September 9, 2009, through December 31, 2010) and does not reflect similar range of hydrologic conditions as other springs.

${ }^{3}$ Relation based on continuous data collection at 15 -minute intervals (mean daily values). 

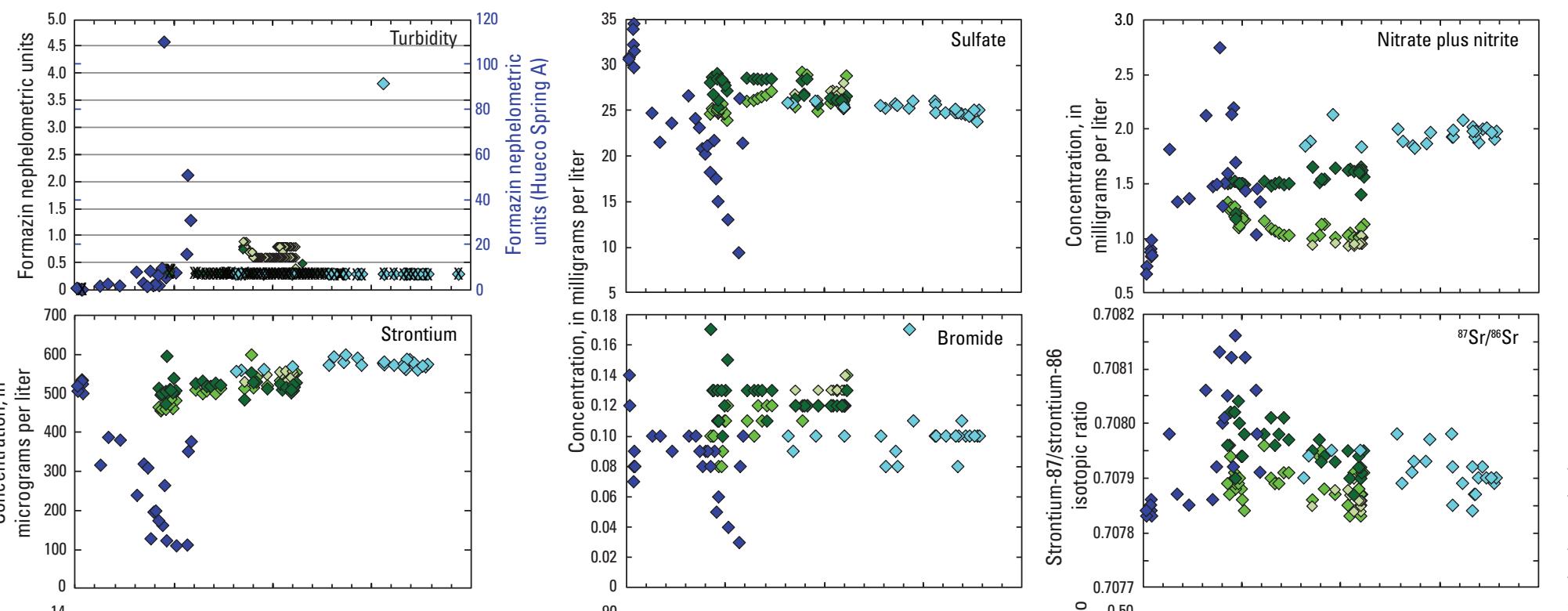

\section{EXPLANATION}
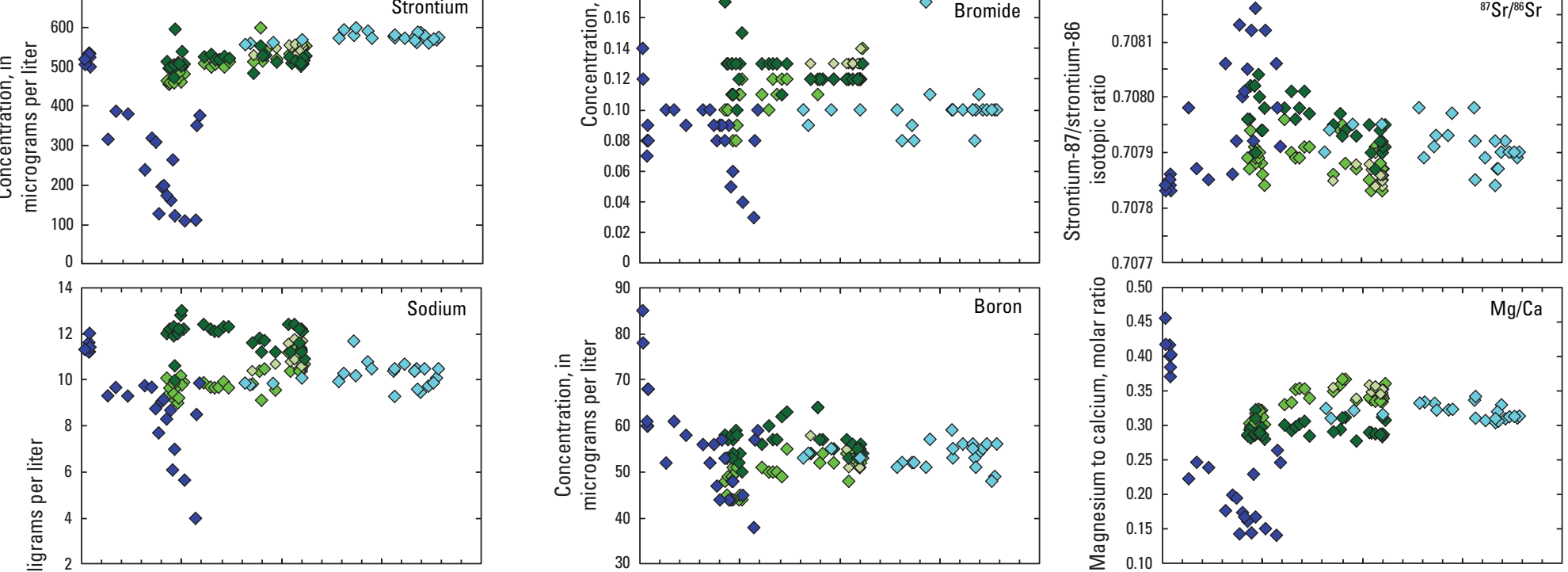

Spring, by orifice (table 1)-Sample

- Deep Spring

$\diamond \quad$ Diversion Spring

Weissmuller Spring

$\diamond \quad$ Comal Spring 1

- Hueco Spring A
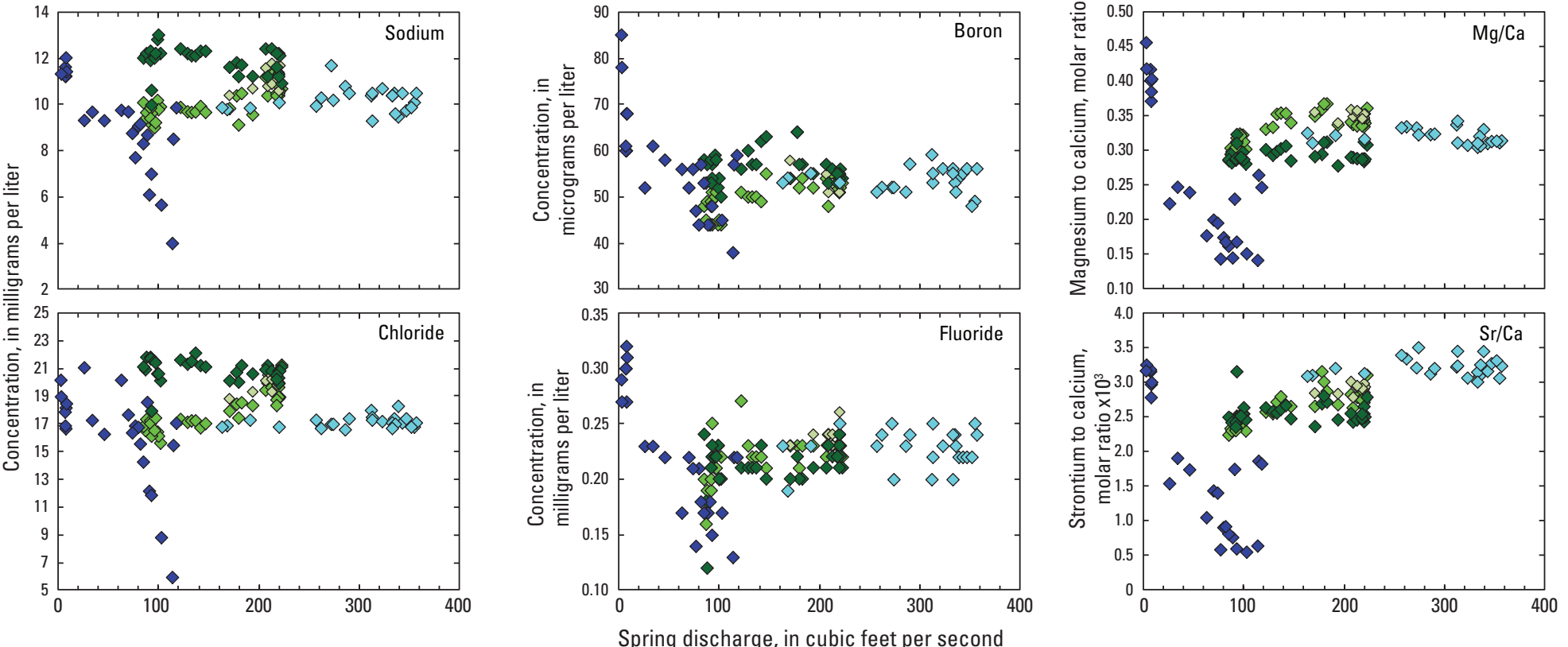

shown at

the method

or laboratory

reporting level

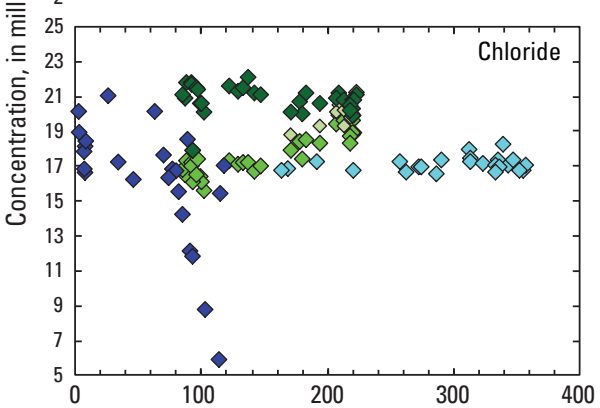

Spring discharge, in cubic feet per second

Figure 27. Relation between spring discharge (daily mean) for Comal, Hueco, and San Marcos Springs and selected physicochemical and geochemical constituents for samples collected from Comal Spring 1, Hueco Spring A, and San Marcos Springs orifices (Deep, Diversion, and Weissmuller Springs), south-central Texas (November 2008-December 2010). 
Hueco Springs is influenced by mixing with a large component of local and recent surface-water recharge, whereas Diversion Spring is not (fig. 24). Second, for many geochemical constituents, the correlation of constituent concentration with spring discharge at Diversion Spring was the inverse of the correlation between constituent concentrations and spring discharge observed at Hueco Springs (table 7; fig. 27). For example, constituents such as $\mathrm{Cl}, \mathrm{Na}, \mathrm{Sr}, \mathrm{Br}$, and lithium ( $\mathrm{Li}$ ) had relatively strong (Kendall's tau $\geq 0.50$ ) positive correlations with discharge at Diversion Spring; other constituents such as $\mathrm{SO}_{4}$ and $\mathrm{F}$ were also positively correlated with discharge at Diversion Spring (table 7). Elevated concentrations of all of these constituents are associated with more saline groundwater and were negatively correlated with discharge at Hueco Springs (table 7; fig. 27). These results are consistent with Hueco Springs being diluted by an increasing component of local surface-water recharge as spring discharge increased. The positive correlation between numerous geochemical constituents and discharge at Diversion Spring also indicates that Diversion Spring is influenced by changing discharge sources with changes in hydrologic conditions. In contrast with Hueco Springs, however, these results indicate that Diversion Spring was influenced by mixing with saline groundwater, rather than surface-water recharge, as hydrologic conditions became wetter. Ratios of $\mathrm{Mg} / \mathrm{Ca}$ and $\mathrm{Sr} / \mathrm{Ca}$ at Diversion Spring are also positively and relatively strongly correlated (Kendall's tau $\geq 0.50$ ) with San Marcos Springs discharge, consistent with an increasing component of more geochemically evolved water as hydrologic conditions became wetter; in contrast, the relation between these constituents at Hueco Springs with spring discharge was inverse (table 7).

\section{Sources of Water to San Marcos Springs}

The orifices of San Marcos Springs sampled during this study exhibited geochemical characteristics that reflect differences in the water sources and flow paths to the orifices, which is consistent with previous studies that have described differences between springs in the southern and northern parts of the lake (Ogden and others, 1986). During the dry period, Deep Spring had higher specific conductance and higher concentrations of numerous constituents associated with more saline groundwater sources (including $\mathrm{Sr}, \mathrm{Na}, \mathrm{Cl}, \mathrm{SO}_{4}, \mathrm{~B}$, and $\mathrm{Br}$ ) than did Diversion Spring (table 5); this indicates that during the dry period Deep Spring was influenced by mixing with a component of saline groundwater. Potential sources of saline groundwater to San Marcos Springs are the downdip Edwards aquifer saline zone and the Trinity aquifer (figs. 1 and 2). Geochemical modeling results consistently indicate that a small amount of saline-zone groundwater (up to 0.2 percent) and (or) Trinity aquifer groundwater (up to 1.3 percent) is needed to account for the composition of all of the modeled orifices at San Marcos Springs (table 6). Model results do not readily distinguish the source of saline groundwater to San Marcos Springs; although groundwater from both sources is geochemically plausible, mixing with saline-zone groundwater is a better geochemical fit (with generally lower mass-balance uncertainties). Relations between selected geochemical constituents and hydrologic conditions indicate that the proportion of saline groundwater contributing to San Marcos Springs increased from dry to wet conditions, in particular for Diversion Spring. This relation is somewhat counterintuitive; with wetter hydrologic conditions, higher water levels in the Edwards aquifer, and larger spring discharges, mixing with fresh recharge sources might be expected to increase and mixing with saline groundwater sources to decrease. Previous studies, however, have noted similar relations in wells in both the San Antonio (Harden, 1968; Mahler, 2008) and the Barton Springs (Garner and Mahler, 2007) segments of the aquifer. Garner and Mahler (2007) proposed that proportionally higher hydraulic heads in the Trinity aquifer relative to the Edwards aquifer during wetter hydrologic conditions might occur. The Solar well, several miles northwest of San Marcos Springs (fig. 1; table 1), also is affected by mixing with a more saline groundwater source during the wet period; concentrations of geochemical constituents such as $\mathrm{Cl}, \mathrm{SO}_{4}, \mathrm{~B}$, and $\mathrm{F}$ increased at the start of the wet period (fig. 15). These changes were accompanied by decreases in $\mathrm{NO}_{3}+\mathrm{NO}_{2}$ and dissolved oxygen concentrations (indicative of mixing with more reducing groundwater), a decrease in ${ }^{87} \mathrm{Sr} /{ }^{86} \mathrm{Sr}$ values and increases in $\mathrm{Mg} / \mathrm{Ca}$ and $\mathrm{Sr} / \mathrm{Ca}$ ratios (indicative of mixing with more geochemically evolved groundwater) (fig. 15). An increase in the proportion of saline groundwater contributing to San Marcos Springs during the wet period, however, is not evident from geochemical modeling results (table 6), possibly because the proportion of saline water is generally small compared to the mass-balance uncertainty.

The spring orifices at San Marcos Springs sampled during this study responded differently to temporal changes in hydrologic conditions, which reflects differences in their water sources and contributing flow paths. Deep Spring was less responsive to changes in hydrologic conditions than was Diversion Spring (fig. 27; table 7), which indicates that discharge at Deep Spring is likely dominated by regional and less variable flow paths; Diversion Spring is likely more affected by changes in recharge sources, which might include local surface-water recharge sources. Increases in the concentrations of $\mathrm{Sr}, \mathrm{Cl}, \mathrm{SO}_{4}, \mathrm{~B}$, and $\mathrm{Br}$ at Diversion Spring from the dry period to the wet period (fig. 18; table 5), however, imply that discharge during the wet period had an increased component of saline groundwater; the composition of discharge from Diversion Spring through the wet period became more like that of Deep Spring. Weissmuller Spring was sampled during only the wet period; the geochemistry of discharge from Weissmuller Spring was similar to that of Diversion Spring, which indicates a similar origin.

Results of this study indicate that recharge from local surface-water sources does not strongly influence the geochemistry of San Marcos Springs discharge. Rather, discharge at San Marcos Springs is dominated by regional recharge sources and flow paths, even during wet hydrologic 
conditions when aquifer recharge is likely occurring from local streams. Geochemical modeling results for the wet period (routine samples) yielded a range for the contribution of local recharge sources (based on the Blanco River) to San Marcos Springs discharge from 0 to 28.9 percent; the range was narrower for Deep Spring (0-17.5 percent) than for Diversion Spring (0-24.4 percent), which is consistent with a more muted response at Deep Spring to changes in hydrologic conditions (table 7). The median value for the midpoint of the range of the local recharge contribution for modeled dates during the wet period was 7.8 percent for Deep Spring and 10.9 percent for Diversion Spring. Model results indicate that the proportion of local stream recharge contributing to San Marcos Springs increased from the dry period to the wet period (fig. 23; table 6). The geochemical response at San Marcos Springs to storm events, when focused local recharge is most likely to occur, was minor (figs. 13 and 19). For example, mixing models for storm 3 , a named tropical storm (Hermine) and the largest storm to occur during the study, indicate that recharge from the Blanco River composed less than 10 percent of discharge at San Marcos Springs immediately following the storm and for several months afterwards (fig. 24). These results place further constraints on the higher proportion of local recharge estimated by PHREEQC and indicate that the local recharge component is likely not more than 10 percent. Mixing models indicate that San Marcos Springs is not notably affected by storm recharge from local focused recharge sources moving rapidly through transmissive flow paths. This hypothesis is supported by time-series data for wells located to the north of San Marcos Springs that might be along flow paths between the Blanco River and San Marcos Springs (Neff and Aqua wells) and that do not show marked changes in geochemistry from the dry period to the wet period (table 5; fig. 15). Local recharge sources contributing to San Marcos Springs would likely vary in their contribution with changes in hydrologic conditions, antecedent conditions for rainfall and recharge events, storm characteristics, aquifer levels, and flow paths. For the large range of hydrologic conditions that occurred during this study, results indicate that discharge at San Marcos Springs is dominated under all conditions by regional flow.

\section{Summary}

The Edwards aquifer in south-central Texas is a productive and important water resource. Several large springs issuing from the aquifer are major discharge points, provide habitat for threatened and endangered species, and are locations for recreational activities. Spring discharges from two of these springs, Comal and San Marcos Springs (the first and second largest spring complexes in Texas), are used as thresholds in groundwater management strategies for the Edwards aquifer. Comal Springs is generally understood to be supplied by regional flow paths. In contrast, the hydrologic connection of San Marcos Springs with the regional Edwards aquifer flow system is less understood, and there is interest in improving the understanding of the hydrogeology and sources of water to San Marcos Springs. The U.S. Geological Survey (USGS) conducted a hydrologic and geochemical study of San Marcos Springs in cooperation with the San Antonio Water System during November 2008-December 2010. The primary objective of the study was to identify and characterize sources of discharge at San Marcos Springs by evaluating hydrologic and geochemical data from streams, groundwater, and springs in the vicinity of San Marcos Springs in Bexar, Comal, and Hays Counties. Springs included three orifices at San Marcos Springs (Deep, Diversion, and Weissmuller Springs) that were selected to be representative of larger springs within the spring complex.

An initial sampling effort characterized surface water, groundwater, and springs in the study area. A subset of sites was selected for periodic (routine; every 3-7 weeks) sampling to characterize temporal changes in water quality in response to hydrologic conditions; these were two streams, eight wells, one spring orifice each at Comal and Hueco Springs, and the three spring orifices at San Marcos Springs (Deep, Diversion, and Weissmuller Springs). To characterize changes in water quality in response to storms, samples were collected (depending on flow) in response to three major storms (storms 1-3) from nearby streams that might contribute recharge to San Marcos Springs and from Comal, Hueco, and San Marcos Springs. The storms varied in size, antecedent moisture conditions, and resulting stream (discharge and recharge) and spring (discharge) response. Storm 1 marked the transition from the dry period to the wet period and occurred following the driest antecedent moisture conditions. Storm 3, a named tropical storm (Hermine), was the largest climatic and hydrologic event during the study with respect to rainfall amount and resulted in large streamflows and aquifer recharge.

Collection of routine and storm-associated samples from streams, wells, and springs over the 25 months of the study provided an opportunity to investigate the hydrogeology of San Marcos Springs under a large range of hydrologic conditions. In addition to routine and storm sample collection, discharge and selected physicochemical properties were measured continuously at a site on the Blanco River and at the three San Marcos Springs orifices; water-table altitude and selected physicochemical properties were measured continuously at two wells near San Marcos Springs. During this study, hydrologic conditions changed from exceptional drought to wetter-than-normal conditions. In this report, the period between November 1, 2008, and September 8, 2009, is referred to as the "dry period," and the period between September 9, 2009, and December 31, 2010, is referred to as the "wet period." Hydrologic and geochemical variability at San Marcos Springs was compared with that at Comal Springs and Hueco Springs, which is illustrative based on the small range of variability observed at Comal Springs and the large range of variability observed at Hueco Springs. 
Streams in the vicinity of San Marcos Springs were evaluated as potential recharge sources. Recharge estimates were computed daily for the Blanco River (2009-10), Cibolo Creek (2008-10), and Dry Comal Creek (2008-10) by using discharge at stations in each basin. Gain/loss estimates also were computed for the Guadalupe River. For the Blanco River, recharge estimates were compared for two station pairs (at Wimberley and Kyle and at Halifax and Kyle), and results were similar. Recharge estimates for these local streams indicate that the amount of recharge to the aquifer varied markedly through the study period with the largest recharge occurring from Dry Comal Creek and the smallest from the Blanco River. The Guadalupe River was largely a gaining stream, which is consistent with previous hypotheses that it does not contribute substantial recharge to the Edwards aquifer or to San Marcos Springs. Sink Creek and Purgatory Creek were dry during most of the study and did not contribute substantial recharge to the Edwards aquifer or to San Marcos Springs on the basis of their short periods of flow and the relatively minor amounts of flow that occurred.

The geochemistry of surface water in sampled streams varied markedly through the study period from the dry period to the wet period and in response to changes in rainfall and corresponding stream discharge. Large and rapid decreases in specific conductance and increases in turbidity occurred in response to rain events. Geochemical constituents in surfacewater samples, including major ions, trace elements, and isotopic compositions, changed following the onset of the wet period in response to dilution from increased rainfall and runoff.

Water-table altitude and specific conductance values at two groundwater wells near San Marcos Springs changed following the onset of the wet period: water-table altitudes increased, reflecting increasing water levels, and specific conductance decreased, reflecting dilution. Both wells had higher specific conductance values than did other Edwards aquifer groundwater wells during the dry period, indicative of contributions from a saline groundwater source. Most groundwater wells in the Edwards aquifer and the Trinity aquifer showed few geochemical changes from the dry period to the wet period. These results indicate that sampled wells were not affected by focused local recharge moving along transmissive (karst conduit) flow paths but were dominated by matrix (diffuse) flow. An exception was the Solar well (LR-67-01-403), where numerous geochemical constituents change markedly at the beginning of the wet period, indicating that groundwater from this well was affected by mixing with a different and more saline groundwater source and (or) the influence of different geochemical processes. Toward the latter part of the wet period to the end of the study, the geochemical composition of the Solar well returned to a composition similar to that observed during the dry period.
Differences in the geochemistry of Comal Springs, Hueco Springs, and San Marcos Springs from the dry period to the wet period provide information on flow paths and recharge sources supplying the springs. During the dry period, little recharge was occurring regionally or locally, and spring discharge from all of the springs predominantly reflects draining of matrix groundwater. There were, however, some notable geochemical differences between the springs during the dry period that likely reflect differences in flow paths and sources of spring discharge. The geochemistry of Hueco Springs during the dry period differed from that of Comal Springs and San Marcos Springs and also varied notably through the dry period, likely reflecting evaporation of the recharge sources supplying Hueco Springs. The geochemistry of Comal Springs and San Marcos Springs was generally similar during the dry period, which is consistent with regional flow paths supplying both springs. There were some notable differences between the geochemistry of Comal Springs and San Marcos Springs, however, which indicate that San Marcos Springs also was influenced by mixing with other water sources (specifically, a source or sources with lower water temperature and lower concentrations of strontium and nitrate plus nitrite). Well 4D (DX-68-16-707), located between Comal Springs and San Marcos Springs in the Comal Springs Fault Block and likely along regional flow paths that supply San Marcos Springs, also had lower temperature and lower concentrations of strontium and nitrate plus nitrite. Samples from Comal Springs and well 4D, which are upgradient from San Marcos Springs, are likely representative of regional groundwater flow paths that contribute to San Marcos Springs. At San Marcos Springs, the geochemistry of the Deep and Diversion Springs orifices during the dry period was similar, although some differences indicate that Deep Spring was more influenced by a small component of saline groundwater.

Changes in hydrologic conditions at the beginning of the wet period were characterized by large changes in spring discharge at all of the springs (Comal, Hueco, and San Marcos Springs). At Hueco Springs, increases in discharge during the wet period were accompanied by large changes in geochemistry. Changes in geochemistry at Comal and San Marcos Springs were minor in comparison, with fewer significant differences or smaller ranges of variability between the dry and wet periods and mostly nominal changes in response to storms. Comal and Hueco Springs are representative of two endmember spring types, with Hueco Springs dominantly affected by more locally sourced conduit flow (quick flow) and Comal Springs dominantly affected by more regionally sourced flow paths (slow flow). These endmember spring types are consistent with timeseries results of geochemical variability for Hueco Springs and Comal Springs. At San Marcos Springs, Deep and Diversion Springs orifices responded differently to changes 
in hydrologic conditions. Deep Spring was not strongly influenced by changes in hydrologic conditions, which indicates that, similar to Comal Springs, discharge at Deep Spring is likely dominated by regional groundwater flow paths. Diversion Spring was more responsive to changes in hydrologic conditions than was Deep Spring, although the range of variability for most geochemical constituents was small, indicating that Diversion Spring was affected by small changes in discharge sources as hydrologic conditions changed. For many geochemical constituents the correlation with spring discharge at Diversion Spring was inverse to that for Hueco Springs, which indicates that, rather than dilute surface-water recharge, Diversion Spring was influenced by a more saline groundwater component.

Inverse modeling with the geochemical model PHREEQC was used to evaluate the potential for mixing of different source-water compositions (regional groundwater flow, local stream recharge, saline-zone groundwater, and Trinity aquifer groundwater) and mass-transfer processes (mineral dissolution/precipitation and ion exchange) that could account for the composition of discharge from San Marcos Springs (Deep, Diversion, and Weissmuller Springs orifices). Modeling results for the routine samples collected during the wet period yielded a range for the contribution of local stream recharge (specifically from the Blanco River) to San Marcos Springs discharge from 0 to less than 30 percent. Additional two-component mixing models using conservative tracers further constrain these results and indicate that the proportion of local recharge is likely lower than the highest values estimated by PHREEQC. The modeled contribution of local stream recharge was narrower for Deep Spring than for Diversion Spring, which is consistent with a more muted response at Deep Spring to changes in hydrologic conditions. The median value for the midpoint of the range of the local recharge contribution for modeled dates (using PHREEQC) during the wet period was 7.8 percent for Deep Spring and 10.9 percent for Diversion Spring. The modeled proportion of local stream recharge accounting for San Marcos Springs discharge increased from the dry period to the wet period.

The geochemical response at San Marcos Springs to storm events, when focused local recharge is most likely to occur, was small. Stable isotope values for rainfall and stream samples associated with storm 3 were distinct from other samples; recharge to the Edwards aquifer in response to storm 3 would reflect these low isotopic values and provide a tracer of recent recharge. Mixing models for storm 3 indicate that recharge from the Blanco River composed less than 10 percent of discharge at San Marcos Springs directly following the storm and for several months afterwards. These results indicate that the effect of storm recharge from local focused recharge sources moving rapidly through transmissive flow paths to San Marcos Springs is small. This conclusion is further supported by time-series data for wells located to the north of San Marcos Springs that might be located along flow paths between the Blanco River and San Marcos Springs and that do not show marked changes in geochemistry from the dry period to the wet period.

The geochemistry of water samples collected routinely and in response to storms from streams, groundwater wells, and springs was used to characterize sources of discharge from San Marcos Springs. Recharge from local surface-water sources does not strongly influence the geochemistry of San Marcos Springs discharge. Rather, results of this study indicate that discharge at San Marcos Springs is dominated by regional recharge and groundwater flow paths, even during wet hydrologic conditions when aquifer recharge is occurring from local streams. A small component of saline groundwater contributes to San Marcos Springs discharge under all hydrologic conditions.

\section{References}

Abbott, P.L., and Woodruff, C.M., Jr., 1986, eds., The Balcones escarpment - Geology, hydrology, ecology and social development in central Texas: Geological Society of America, $200 \mathrm{p}$.

Ashworth, J.B., and Hopkins, Janie, 1995, Aquifers of Texas: Texas Water Development Board Report 345, 69 p.

Atkinson, T.C., 1977, Diffuse flow and conduit flow in limestone terrain in the Mendip Hills, Somerset (Great Britain): Journal of Hydrology, v. 35, p. 93-110.

Barker, R.A., and Ardis, A.F., 1996, Hydrogeologic framework of the Edwards-Trinity aquifer system, west-central Texas: U.S. Geological Survey Professional Paper 1421-B, 61 p.

Brune, Gunnar, 1975, Major and historical springs of Texas: Texas Water Development Board Report 189, 94 p.

City of Austin, 1997, The Barton Creek report: City of Austin, Water Quality Report Series, $460 \mathrm{p}$.

Clement, T.J., 1989, Hydrochemical facies of the badwater zone of the Edwards aquifer, central Texas: Austin, Tex., University of Texas at Austin, M.A. thesis, 168 p.

Coplen, T.B., Hopple, J.A., Böhlke, J.K., Peiser, H.S., Rieder, S.E., Krouse, H.R., Rosman, K.J.R., Ding, T., Vocke, R.D., Jr., Révész, K.M., Lamberty, A., Taylor, P.D.P., and De Bièvre, P., 2002, Compilation of minimum and maximum isotope ratios of selected elements in naturally occurring terrestrial materials and reagents: U.S. Geological Survey Water-Resources Investigations Report 01-4222, 98 p. 
Craig, Harmon, 1961, Isotopic variations in meteoric waters: Science, v. 133, p. 1702-1703.

Crow, C.L., 2012, Geochemical and hydrologic data for San Marcos Springs recharge characterization near San Marcos, Texas, November 2008-December 2010: U.S. Geological Survey Data Series 672, 19 p., 16 appendixes.

DeCook, K.J., 1956, Geology of San Marcos Springs quadrangle, Hays County, Texas: Austin, Tex., University of Texas at Austin, M.A. thesis, $90 \mathrm{p}$.

DeCook, K.J., 1960, Geology and ground-water resources of Hays County, Texas: Texas Board of Water Engineers, Bulletin 6004, $167 \mathrm{p}$.

Desmarais, Kathryn, and Rojstaczer, Stuart, 2002, Inferring source waters from measurements of carbonate spring responses to storms: Journal of Hydrology, v. 260, p. $118-134$.

Edwards Aquifer Authority, 2010, Hydrologic Data Report for 2009, Edwards Aquifer Authority, San Antonio, Texas, $340 \mathrm{p}$.

Edwards Aquifer Research and Data Center, 2010, Threatened and endangered species in the Edwards aquifer system: accessed January 29, 2010, at http://www.eardc.txstate.edu/ about/endangered.html.

Fahlquist, Lynne, and Ardis, A.F., 2004, Quality of water in the Trinity and Edwards aquifers, south-central Texas, 1996-98: U.S. Geological Survey Scientific Investigations Report 2004-5201, 17 p.

Fairchild, I.J., Borsato, Andrea, Tooth, A.F., Frisia, Silvia, Hawkesworth, C.J., Huang, Yiming, McDermott, Frank, and Spiro, Baruch, 2000, Controls on trace element (Sr-Mg) compositions of carbonate cave watersImplications for speleothem climatic records: Chemical Geology, v. 166, p. 255-269.

Ford, Derek, and Williams, Paul, 2007, Karst hydrogeology and geomorphology: Chicester, England, Wiley, 562 p.

Fritz, Peter, and Fontes, J.C., eds., 1980, Handbook of environmental isotope geochemistry, v. 1-The terrestrial environment: Amsterdam, Elsevier, 545 p.

Garner, B.D., 2005, Geochemical evolution of ground water in the Barton Springs segment of the Edwards aquifer: Austin, Tex., University of Texas at Austin, M.S. thesis, 317 p.
Garner, B.D., and Mahler, B.J., 2007, Relation of specific conductance in ground water to intersection of flow paths by wells, and associated major ion and nitrate geochemistry, Barton Springs segment of the Edwards aquifer, Austin, Texas, 1978-2003: U.S. Geological Survey Scientific Investigations Report 2007-5002, 39 p.

Groschen, G.E., and Buszka, P.M., 1997, Hydrogeologic framework and geochemistry of the Edwards aquifer salinewater zone, south-central Texas: U.S. Geological Survey Water-Resources Investigations Report 97-4133, 47 p.

Guyton, W.F. and Associates, 1979, Geohydrology of Comal, San Marcos, and Hueco Springs: Austin, Tex., Texas Department of Water Resources Report 234, 85 p.

Harden, R.W., 1968, Review of water quality changes in the Edwards reservoir, especially near the bad water line: Austin, Tex., R.W. Harden and Associates, Inc., 23 p. [file memorandum].

Helsel, D.R., and Hirsch, R.M., 2002, Hydrologic analysis and interpretation - Statistical methods in water resources: U.S. Geological Survey Techniques of Water-Resources Investigations, book 4, chap. A3, accessed September 2008, at http://pubs.usgs.gov/twri/twri4a3/html/pdf_new.html.

Hem, J.D., 1989, Study and interpretation of the chemical characteristics of natural water (3d ed.): U.S. Geological Survey Water-Supply Paper 2254, $264 \mathrm{p}$.

Herczeg, A.L., and Edmunds, W.M., 2000, Inorganic ions as tracers, in Cook, P.G., and Herczeg, A.L., eds., Environmental tracers in subsurface hydrology: Dordrecht, The Netherlands, Kluwer Academic Publishing, p. 31-77.

Johnson, S.B., and Schindel, G.M., 2008, Evaluation of the option to designate a separate San Marcos pool for critical period management: San Antonio, Tex., Edwards Aquifer Authority, $109 \mathrm{p}$.

Johnson, Steven; Schindel, Geary; Veni, George; Hauwert, Nico; Hunt, Brian; Smith, Brian; and Gary, Marcus, 2012, Tracing groundwater flowpaths in the vicinity of San Marcos Springs, Texas: San Antonio, Tex., Edwards Aquifer Authority, $139 \mathrm{p}$.

Kennedy, E.J., 1983, Computation of continuous records or streamflow: U.S. Geological Survey Techniques of Water-Resources Investigations, book 3, chap. A13, 53 p., available at http://pubs.usgs.gov/twri/twri3-a13/. 
Kennedy, E.J., 1984, Discharge ratings at gaging stations: U.S. Geological Survey Techniques of Water-Resources Investigations, book 3, chap. A10, 59 p., available at http://pubs.usgs.gov/twri/twri3-a10/.

Klemt, W.B., Knowles, T.R., Edler, G.R., and Sieh, T.W., 1979, Ground-water resources and model applications for the Edwards (Balcones fault zone) aquifer in the San Antonio region: Texas Water Development Board Report 239, 88 p.

Koepnick, R.B., Burke, W.H., Denison, R.E., Hetherington, E.A., Nelson, H.F., Otto, J.B., and Waite, L.E., 1985, Construction of the seawater ${ }^{87} \mathrm{Sr} /{ }^{86} \mathrm{Sr}$ curve for the Cenozoic and Cretaceous-Supporting data: Chemical Geology (Isotope Geoscience Section), v. 58, p. 55-81.

Lakey, Barbara, and Krothe, N.C., 1996, Stable isotopic variation of storm discharge from a perennial karst spring, Indiana: Water Resources Research, v. 32, no. 3 , p. $721-731$.

Lambert, R.B., Hunt, A.G., Stanton, G.P., and Nyman, M.B., 2009, Water-level, borehole geophysical log, and waterquality data from wells transecting the freshwater/salinewater interface of the San Antonio segment of the Edwards aquifer, south-central Texas, 1999-2007: U.S. Geological Survey Data Series 403 [variously paged], accessed July 26, 2011, at http://pubs.usgs.gov/ds/403/.

Lawrence, J.R., 1998, Isotopic spikes from tropical cyclones in surface waters - Opportunities in hydrology and paleoclimatology: Chemical Geology, v. 144, p. 153-160.

Lawrence, J.R., and Gedzelman, S.D., 1996, Low stable isotope ratios of tropical cyclone rains: Geophysical Research Letters, v. 23, p. 527-530.

LBG-Guyton Associates, 1995, Edwards aquifer ground-water divides assessment, San Antonio region, Texas: San Antonio, Tex., Edwards Underground Water District Report 95-01, 35 p.

LBG-Guyton Associates, 2004, Evaluation of augmentation methodologies in support of in-situ refugia at Comal and San Marcos Springs, Texas: Report prepared for the Edwards Aquifer Authority [variously paged].
Lindgren, R.J., Dutton, A.R., Hovorka, S.D., Worthington, S.R.H., and Painter, Scott, 2004, Conceptualization and simulation of the Edwards aquifer, San Antonio region, Texas: U.S. Geological Survey Scientific Investigations Report 2004-5277, 143 p.

Lohmann, K.C., 1988, Geochemical patterns of meteoric diagenetic systems and their application to studies of paleokarst, in James, N.P., and Choquette, P.W., eds., Paleokarst: New York, Springer-Verlag, p. 58-80.

Lowry, R.L., 1955, Recharge to Edwards ground-water reservoir: Consultant report to San Antonio City Water Board, $66 \mathrm{p}$.

Lucey, K.J., and Goolsby, D.A., 1993, Effects of climatic variations over 11 years on nitrate-nitrogen concentrations in the Raccoon River, Iowa: Journal of Environmental Quality, v. 22, no. 1, p. 38-46.

Mace, R.E., Chowdhury, A.H., Anaya, Roberto, and Way, S.C., 2000, Groundwater availability of the Trinity aquifer, Hill Country area, Texas-Numerical simulations through 2050: Texas Water Development Board Report 353, 169 p.

Maclay, R.W., 1995, Geology and hydrology of the Edwards aquifer in the San Antonio area, Texas: U.S. Geological Survey Water-Resources Investigations Report 95-4186, 64 p.

Maclay, R.W., and Land, L.F., 1988, Simulation of flow in the Edwards aquifer, San Antonio region, Texas, and refinements of storage and flow concepts: U.S. Geological Survey Water-Supply Paper 2336-A, 48 p.

Maclay, R.W., and Small, T.A., 1983, Hydrostratigraphic subdivisions and fault barriers of the Edwards aquifer, south-central Texas, U.S.A.: Journal of Hydrology, v. 61, p. $127-146$.

Mahler, B.J., 2008, Statistical analysis of major ion and trace element geochemistry of water, 1986-2006, at seven wells transecting the freshwater/saline-water interface of the Edwards aquifer, San Antonio, Texas: U.S. Geological Survey Scientific Investigations Report 2008-5224, 46 p.

Mahler, B.J., and Garner, B.G., 2009, Using nitrate to quantify quick flow in a karst aquifer: Ground Water, v. 47, no. 3 , p. $350-360$. 
Mahler, B.J., Garner, B.D., Musgrove, M., Guilfoyle, Amber, and Rao, M.V., 2006, Recent (2003-05) water quality of Barton Springs, Austin, Texas, with emphasis on factors affecting variability: U.S. Geological Survey Scientific Investigations Report 2006-5299, 83 p., 5 appendixes.

Mahler, B.J., and Massei, Nicolas, 2007, Anthropogenic contaminants as tracers in an urbanizing karst aquifer: Journal of Contaminant Hydrology, v. 91, p. 81-106.

Mahler, B.J., Musgrove, M., Sample, T.L., and Wong, C.I., 2011, Recent (2008-10) water quality in the Barton Springs segment of the Edwards aquifer and its contributing zone, central Texas, with emphasis on factors affecting nutrients and bacteria: U.S. Geological Survey Scientific Investigations Report 2011-5139, 66 p.

Martin, J.B., and Screaton, E.J., 2001, Exchange of matrix and conduit water with examples from the Floridan aquifer, in Kuniansky, E.L., ed., U.S. Geological Survey Karst Interest Group Proceedings, St. Petersburg, Fla., Feb. 13-16, 2001: U.S. Geological Survey Water-Resources Investigations Report 01-4011, p. 38-44.

Massei, Nicolas, Mahler, B.J., Bakalowicz, Michel, Fournier, Matthieu, and Dupont, J.P., 2007, Quantitative interpretation of specific conductance frequency distributions in karst: Ground Water, v. 45, p. 288-293.

McKinney, D.C., and Sharp, J.M., Jr., 1995, Springflow augmentation of Comal Springs and San Marcos Springs, Texas: Phase I Feasibility Study, Center for Research in Water Resources Technical Report 247, 416 p.

Musgrove, M., and Banner, J.L., 2004, Controls on the spatial and temporal variability of vadose dripwater geochemistry_Edwards aquifer, central Texas: Geochimica et Cosmochimica Acta, v. 68, p. 1007-1020.

Musgrove, M., Fahlquist, L., Houston, N.A., Lindgren, R.J., and Ging, P.B., 2010, Geochemical evolution processes and water-quality observations based on results of the National Water-Quality Assessment Program in the San Antonio segment of the Edwards aquifer, 1996-2006: U.S. Geological Survey Scientific Investigations Report 2010-5129, 93 p. (Also available at http://pubs.usgs.gov/ $\operatorname{sir} / 2010 / 5129 /$.
National Aeronautics and Space Administration, 2012, Hurricanes/tropical cyclones, past year archives: accessed May 28, 2012, at http:/www.nasa.gov/mission_pages/ hurricanes/archives/2010/past-years-2010.html.

National Oceanic and Atmospheric Administration, 2011, National Climatic Data Center, climatological data for cooperative stations 411429, 412585, 416276, 417983, 418544, and 419815: accessed February 3, 2011, at http://www.ncdc.noaa.gov/oa/ncdc.html.

Ockerman, D.J., 2005, Simulation of streamflow and estimation of recharge to the Edwards aquifer in the Hondo Creek, Verde Creek, and San Geronimo Creek watersheds, south-central Texas, 1951-2003: U.S. Geological Survey Scientific Investigations Report 2005-5252, 37 p.

Oetting, G.C., 1995, Evolution of fresh and saline groundwaters in the Edwards aquifer-Geochemical and $\mathrm{Sr}$ isotopic evidence for regional fluid mixing and fluid-rock interaction: Austin, Tex., University of Texas at Austin, M.A. thesis, 204 p.

Oetting, G.C., Banner, J.L., and Sharp, J.M., Jr., 1996, Geochemical evolution of saline groundwaters in the Edwards aquifer, central Texas - Regional stratigraphic, tectonic, and hydrodynamic controls: Journal of Hydrology, v. 181, p. 251-283.

Ogden, A.E., Quick, R.A., Rothermel, S.R., and Lundsford, D.L., 1986, Hydrological and hydrochemical investigation of the Edwards aquifer in the San Marcos area, Hays County, Texas: San Marcos, Tex., Edwards Aquifer Research and Data Center, 364 p.

Ogden, A.E., Spinelli, A.J., and Horton, Jack, 1985a, Hydrologic and hydrochemical data for the Edwards aquifer in Hays and Comal Counties, October 1981 to September 1983: San Marcos, Tex., Southwest Texas State University, Edwards Aquifer Research and Data Center Report R1-85, 102 p.

Ogden, A.E., Spinelli, A.J., and Horton, Jack, 1985b, Hydrologic and hydrochemical data for the Edwards aquifer in Hays and Comal Counties, October 1983 to June 1985: San Marcos, Tex., Southwest Texas State University, Edwards Aquifer Research and Data Center Report R2-85, 83 p. 
Otero, C.L., 2007, Geologic, hydrologic, and geochemical identification of flow paths in the Edwards aquifer, northeastern Bexar and southern Comal Counties, Texas: U.S. Geological Survey Scientific Investigations Report 2007-5285, 48 p.

Pape, J.R., Banner, J.L., Mack, L.E., Musgrove, M., and Guilfoyle, Amber, 2010, Controls on oxygen isotope variability in precipitation and cave drip waters, central Texas, USA: Journal of Hydrology, v. 385, p. 203-215.

Parkhurst, D.L., and Appelo, C.A.J., 1999, User's guide to PHREEQC (v. 2)-A computer program for speciation, reaction-path, one-dimensional transport, and inverse geochemical calculations: U.S. Geological Survey Water-Resources Investigations 99-4259, 312 p.

Pearson, F.J., Jr., Rettman, P.L., and Wyerman, T.A., 1975, Environmental tritium in the Edwards aquifer, central Texas 1963-7: U.S. Geological Survey Open-File Report 74-362, 12 p.

Pinault, J.L., Plagnes, Valérie, Aquilina, Luc, and Balakowicz, Michel, 2001, Inverse modeling of the hydrological and the hydrochemical behavior of hydrosystemsCharacterization of karst system functioning: Water Resource Research, v. 37, p. 2191-2204.

Plummer, L.N., 1977, Defining reactions and mass transfer in part of the Floridan aquifer: Water Resources Research, v. 13 , p. $801-812$.

Puente, Celso, 1976, Statistical analysis of water-level, springflow, and streamflow data for the Edwards aquifer in south-central Texas: U.S. Geological Survey Open-File Report 76-393, $59 \mathrm{p}$.

Puente, Celso, 1978, Method of estimating natural recharge to the Edwards aquifer in the San Antonio area, Texas: U.S. Geological Survey Water-Resources Investigations Report 78-10, $34 \mathrm{p}$.

Quinlan, J.F., 1989, Ground-water monitoring in karst terranes-Recommended protocols and implicit assumptions: U.S. Environmental Protection Agency, EPA/600/X-89/050, accessed February 3, 2011 at http://www.epa.gov/oust/cat/gwkarst.pdf.

Reynolds, Brian, and Edwards, Anthony, 1995, Factors influencing dissolved nitrogen concentrations and loadings in upland streams of UK: Agricultural Water Management, v. 27 , p. 181-202.
Rose, P.R., 1972, Edwards group, surface and subsurface, central Texas: Bureau of Economic Geology Report of Investigations 74 .

Rothermel, S.R., and Ogden, A.E., 1986, Hydrochemical investigation of the Comal and Hueco spring systems, Comal County, Texas: San Marcos, Tex., Edwards Aquifer Research and Data Center Report Number R2-86, 151 p.

Scanlon, B.R., and Thrailkill, John, 1987, Chemical similarities among physically distinct spring types in a karst terrain: Journal of Hydrology, v. 89, p. 259-279.

Schultz, A.L., 1994, 1994 review and update of the position of the Edwards aquifer freshwater/saline-water interface from Uvalde to Kyle, Texas: Edwards Underground Water District Report 94-05, 31 p.

Sharp, J.M., Jr., and Banner, J.L., 1997, The Edwards aquifer-A resource in conflict: GSA Today, v. 7, p. 1-9.

Sharp, J.M., Jr., and Clement, T.J., 1988, Hydrochemical facies as hydraulic boundaries in karstic aquifers-The Edwards aquifer, U.S.A., in Daoxian, Y., ed., Karst hydrogeology and karst environmental protection-Proceedings of the 21st International Association of Hydrologists Congress, Guilin, China, October 10-15, 1988: Beijing, China, Geological Publishing House, p. 841-845.

Shuster, E.T., and White, W.B., 1971, Seasonal fluctuations in the chemistry of limestone springs-A possible means for characterizing carbonate aquifers: Journal of Hydrology, v. 14, p. $93-128$.

Texas Legislature Online, 2007, Senate Bill 3: accessed March 18, 2011, at http://www.capitol.state.tx.us/ BillLookup/History.aspx?LegSess=80R\&Bill=SB3.

Thorkildsen, D.F., and McElhaney, P.D., 1992, Model refinement and applications for the Edwards (Balcones fault zone) aquifer in the San Antonio region, Texas: Texas Water Development Board Report 340, 33 p.

Trudgill, S.T., Laidlaw, I.M.S., and Smart, P.L., 1980, Soil water residence times and solute uptake on a dolomite bedrock - Preliminary results: Earth Surface Processes, v. 5, p. $91-100$.

U.S. Department of Agriculture, 2010, National agriculture imagery program (NAIP): U.S. Department of Agriculture, Farm Service Agency - Aerial photography field office, accessed February 17, 2012, at http://www.fsa.usda.gov/ Internet/FSA_File/naip03_09covermaps.pdf. 
U.S. Drought Monitor, 2011, Drought monitor archives: accessed July 26, 2011, at http://droughtmonitor.unl.edu/ archive.html.

U.S. Environmental Protection Agency, 2006, Region 6 water programs - Designated sole source aquifers: accessed February 3, 2011 at http://www.epa.gov/region6/ water/swp/ssa/maps.htm.

U.S. Geological Survey, 2011, National Water Information System-U.S. Geological Survey water data for Texas: accessed March 23, 2011, at http://waterdata.usgs.gov/tx/nwis/.

Vesper, D.J., and White, W.B., 2004, Storm pulse chemographs of saturation index and carbon dioxide pressure-Implications for shifting recharge sources during storm events in the karst aquifer at Fort Campbell, Kentucky/Tennessee, USA: Hydrogeology Journal, v. 12 , p. $135-143$.

Wanakule, Nisai, 1988, Regression analysis of the San Marcos Spring flows and water levels of the index well in San Antonio: San Marcos, Tex., Southwest Texas State University, Edwards Aquifer Research and Data Center Report R1-88, 72 p.
White, W.B., 1988, Geomorphology and hydrology of karst terrains: New York, Oxford University Press, 464 p.

White, W.B., 1999, Conceptual models for karstic aquifers, in Palmer, A.N., Palmer, M.V., and Sasowsky, I.D., eds., Karst modeling: Karst Waters Institute Special Publication, v. 5, p. 11-16.

White, W.B., 2002, Karst hydrology—Recent developments and open questions: Engineering Geology, v. 65, p. 85-105.

Wong, Corinne, Banner, J.L., and Musgrove, M., 2011, Seasonal drip-water $\mathrm{Mg} / \mathrm{Ca}$ and $\mathrm{Sr} / \mathrm{Ca}$ variations driven by cave ventilation-Implications for and modeling of speleothem paleoclimate records: Geochimica et Cosmochimica Acta, v. 75, p. 3514-3529.

Woodruff, C.M., Jr., and Abbott, P.L., 1986, Stream piracy and evolution of the Edwards aquifer along the Balcones Escarpment, central Texas, in Abbot, P.L., and Woodruff, C.M., Jr., eds., The Balcones Escarpment—Geology, hydrology, ecology and social development in central Texas: Geological Society of America, p. 77-100.
Publishing support provided by

Lafayette Publishing Service Center

Information regarding water resources in Texas is available at http://tx.usgs.gov/ 

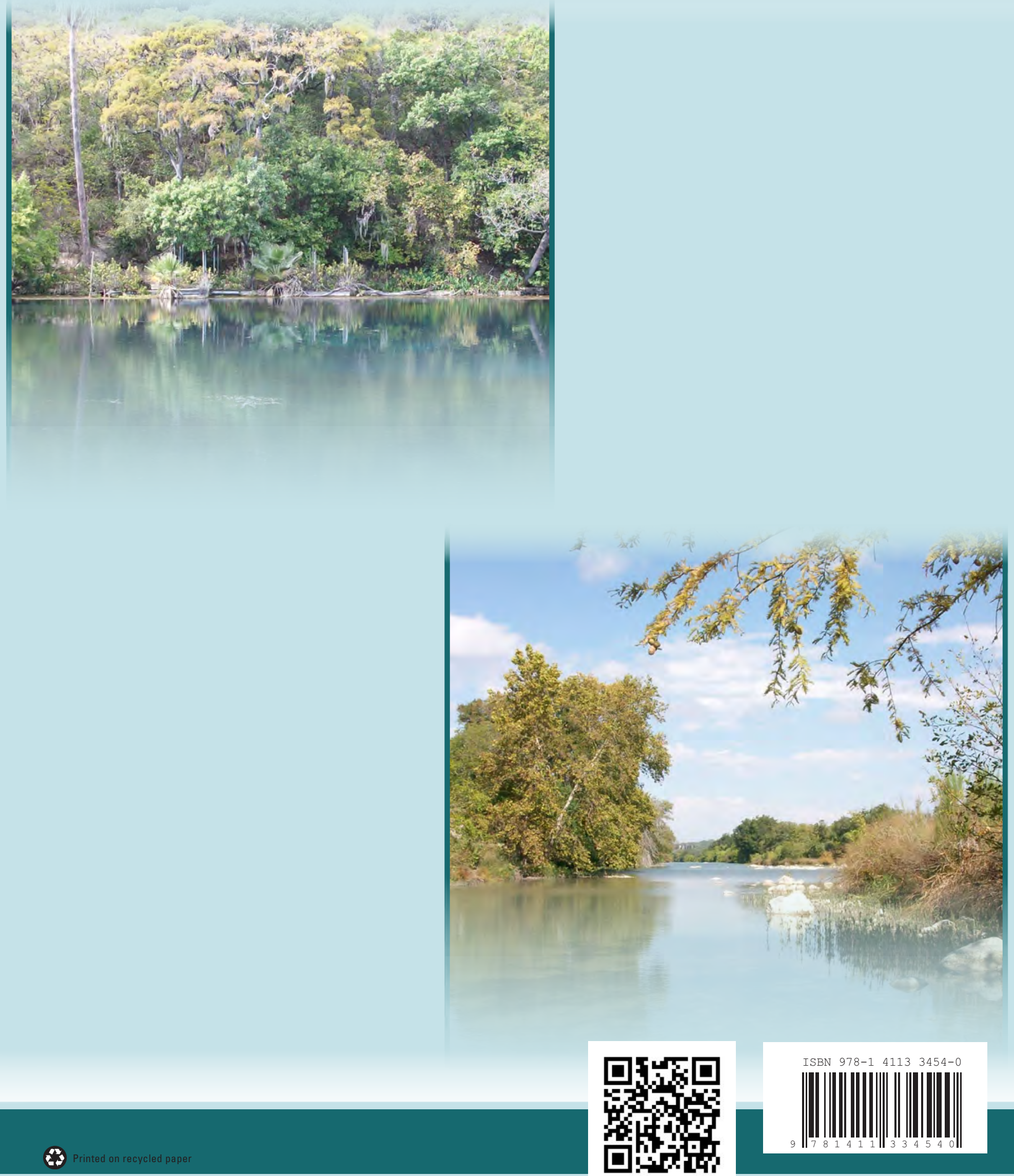